\title{
Good Sport
}

with Famous Packs

$1885-1910$

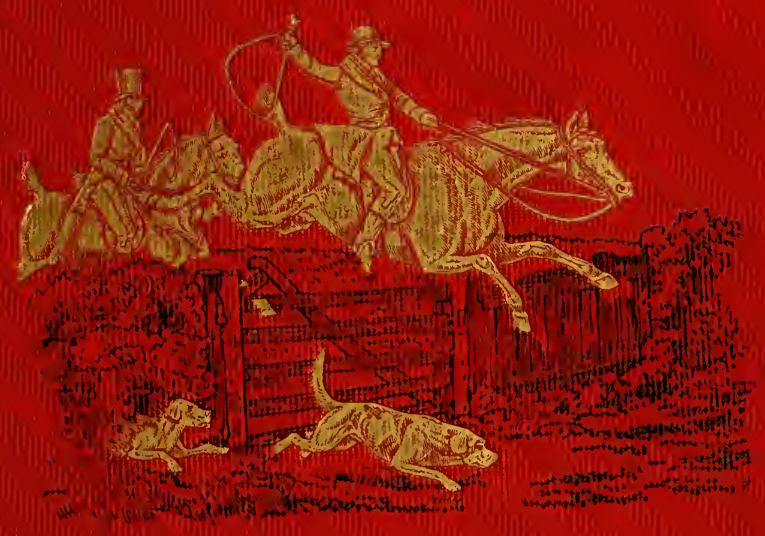

BY CUTPBERT BRADLEY 


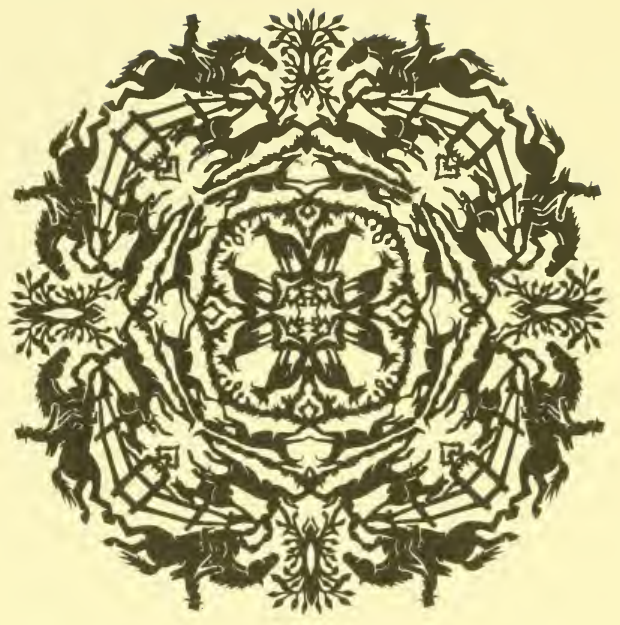

\section{JOHN A.SEAVERNS}


TUFTS UNIVERSITY LIBRARIES

39090014537266 

GOOD SPORT 




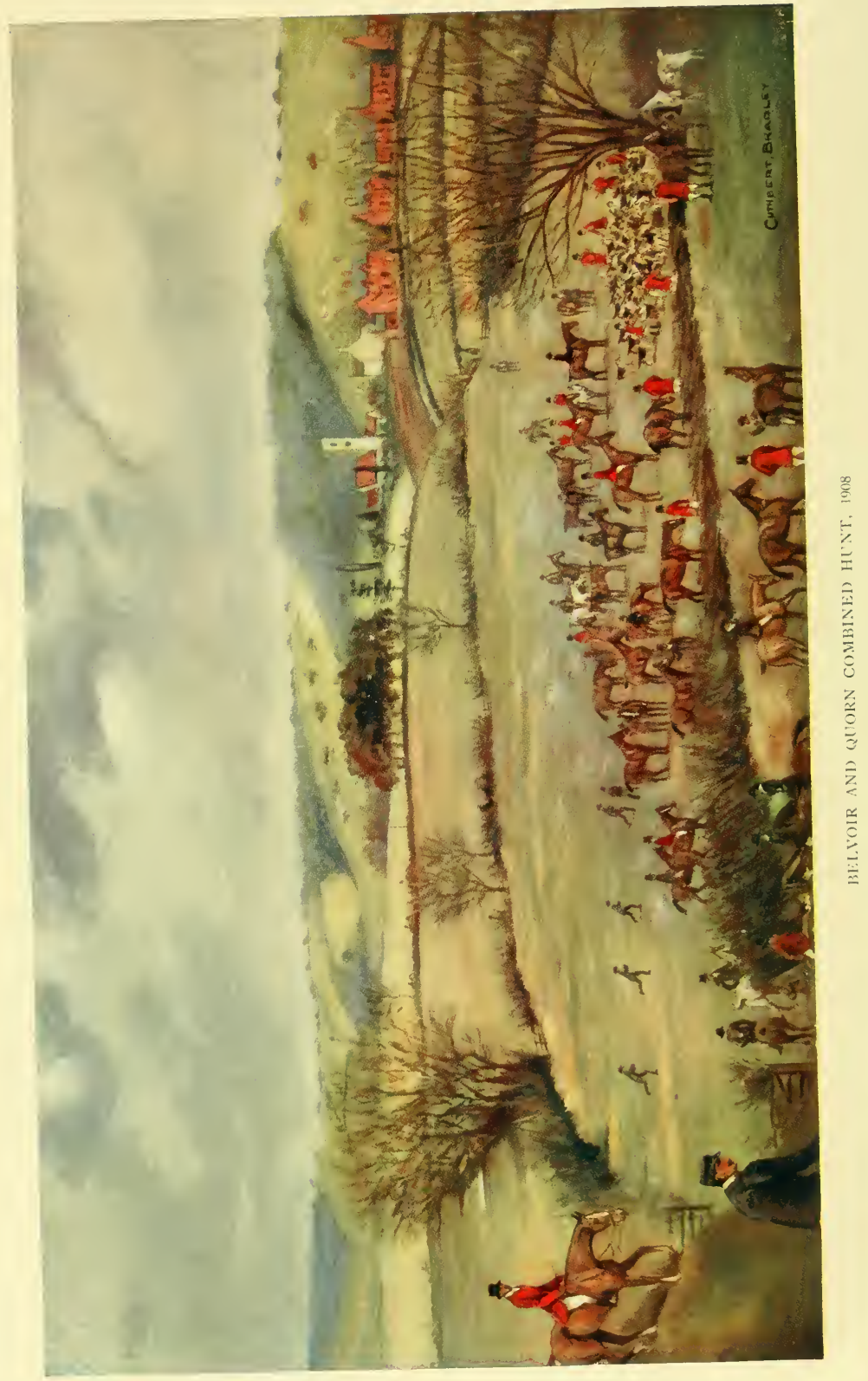




\title{
GOOD SPORT
}

\section{SEEN WITH SOME FAMOUS PACKS}

\author{
I $885-19$ I 0 \\ BY

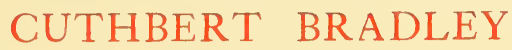 \\ (“WHIPSTER") \\ AUTHOR OF "REMINISCENCES OF FRANK GILLARD, HUNTSMAN TO \\ THE IUKE OF RUTLAND'S HOUNDS"
}

IVITH TEN FULL-PAGE ILLUSTRATIONS, INCLUDING SIX IN COLOUR, NUMEROUS TEXT CUTS AND A HUNTING NOTE BY THE Right Hon. HENRY CHAPLIN, M.P. EX-MASTER OF THE BLANKNEY

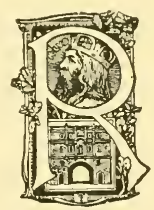

LONDON

GEORGE ROUTLEDGE AND SONS, Limited NEW YORK: E. P. DUTTON AND CO. 
Printed by Ballantyne, Hanson \& Co. At the Ballantyne Press, Edinburgh 


\section{P R E F A C E}

WITH HUNTING NOTE BY THE RIGHT HON. HENRY CHAPLIN, M.P., EX-MASTER OF THE BLANKNEY

"A THING of beauty is a joy for ever,"-a line which might have been written with special reference to the foxhound, whose beautiful symmetry captivates the eye, whose marvellous powers in chase cheer the heart, and whose memory is perpetuated by generations of descendants showing the same characteristics. No wonder as time goes on the popularity of the noble animal increases, and a larger number of people are interested in foxhound lore than at any other period in the history of the chase, including puppy-walkers and others, who do not hunt, but follow every detail of the game with critical intelligence. This is not to be wondered at; for a foxhound is a triumph of breeding and selection, an animal that has kept pace with the requirements of the age in a marvellous way, without sacrificing any of the sterling merits which distinguished the celebrities of the past. Beautiful packs of hounds to-day are to be found up and down England, for no animal has generally improved in appearance so rapidly during the past ten or fifteen years - a lasting testimony to masters whose judgment moulds the destinies of a kennel, a reflected glory to a hunt and a community whose fame is ensured by the excellence of its pack.

Mr. Henry Chaplin, in a kindly letter written from Bagnolesde l'Orne, Normandy, June 23, IgIo, 
gives a most interesting summary of the past, which is undoubtedly the foundation of modernday excellence.

Referring to his mastership of the Blankney from I877 to I885, Mr. Chaplin writes:

"The proofs I have looked at with interest, for any task connected with hunting in Lincolnshire is thoroughly congenial to me. The Blankney were shorn of their glory, after the pack which I bought of the late Lord Henry Bentinck, and then sold to Lord Lonsdale, were dispersed by him. There was little, I am afraid, of Lord Henry's sort left at Blankney, and the present pack, I fancy, has but little connection with Lord Henry's, which at one time, in the opinion of many of the best and finest judges of the time, stood almost alone.

"The Beaufort are, and have been for many generations, a first-class pack of hounds, but never probably so good as they are to-day.

" The Belvoir were in Goodall's time the fountainhead of everything, and though they have altered in size and character since his day, and have never worked for any one as they did for him, they are still in my opinion a remarkable kennel, probably the most so.

"The Quorn under Tom Firr were the handiest and best-broken pack in England, but otherwise never in the first class since the days of old Sir Richard Sutton, though in the open Firr could do anything with them, and showed excellent sport.

"The Cottesmore, until Lord Lonsdale brought the present pack, were never in the first class, or near it, in my recollection-alas a long one !-excepting in the time of his father, who had some wonderful animals in the pack."

Something over twenty seasons' hunt corre- 
spondent work has been a labour of love, living over again the enjoyable moments spent in the field and in the kennel with many famous packs of hounds, to whose noble owners we are deeply grateful for much kindness and encouragement. The story and impressions thus gleaned of hounds and many good sportsmen met in our travels, is rather intended as a pleasurable résumé of an enjoyable life, and not a critical survey of the chase. In time to come, when we have vanished from the scene and other players take their part in the great drama of fox-hunting, these impressions of a very good time spent with hounds, we venture to think, must be of interest, for names of sportsmen as well as hounds crop up again in the third and fourth generations, and the "old country" welcomes such back to the land of their ancestors.

To kindly editors of Land and Water years ago, and especially our "friend and guide," the late Captain J. Moray Brown, with whom we served an apprenticeship as hunt correspondent, we are sincerely grateful. For permission to reproduce some pen and pencil incidents of the chase, contributed week by week through many seasons' hunting, we thank the proprietors of the Graphic, Daily Graphic, the Field, the County Gentleman, Vanty Fair, the Crown, Baily's Magazine, Fores' Magazine, Sporting Pictorial, the Grantham Journal, and others, who have so kindly lent us assistance on many occasions.

Early impressions of hounds and hunting were implanted by Frank Gillard, huntsman to the Dukes of Rutland for twenty-six seasons, who inspired us with the love of form and symmetry in the foxhound during many visits to Belvoir kennels, and whose "Reminiscences" it was our privilege to 
write. We have hunted long enough to see two different systems in the field-the old style in less hurried times, and the modern system at greater speed and higher tension-but can truly say that the best of sport has been enjoyed with each. Foxhunting has made country life what it is, and keeps it as it is: long may "Good Sport" flourish in the land!

CUTHBERT BRADLEY. 


\section{CONTENTS}

PREFACE .

List of Plates

$$
\text { CHAPTER I }
$$

Peterborough Memories, I88I-1909 • . . . . . I

CHAPTER II

The Quorn at Kirby Gate $\quad$. . . . . 28

CHAPTER III

With Frank Gillard on a Lenton Brook Day. Forty Minutes And A Kill . . . . . . . 44

CHAPTER IV

Two Good Days in in89 seen with the Cottesmore and George Gillson . . . . . . . $\quad 5^{8}$

CHAPTER V

A Hunt with the Duke of Beaufort's Hounds . . 7 r

CHAPTER VI

Good Grey Hunters . . . . . . . . . 83

CHAPTER VII

Blankney Reminiscences of Six Masterships • . 96

\section{CHAPTER VIII}

A Hunt with Mr. Charles McNeill and the North CotsWOLd HOUNDS . . . . . . . . . . II3

\section{CHAPTER IX}

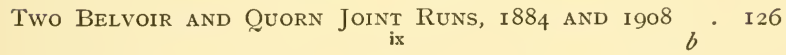




\section{CHAPTER $\mathrm{X}$}

A Hunt with the EARl of Lonsdale, visiting the IVoodLAND Pytchley Country . . . . . . I 50

\section{CHAPTER XI}

VARsity DAYS REVIVED WITH THE CAMBRIDGEshire AND

Mr. Douglas Crossman . . . . . . . 163

CHAPTER XII

Fox-Hunting Jehus, Past and Present . . . . 174

\section{CHAPTER XIII}

Yorkshire Hunters AND Hounds . . . . . I86

\section{CHAPTER XIV}

Hunting with the Cottesmore and Arthur Thatcher . ig6

\section{CHAPTER XV}

The Marouis of Exeter's Hounds hunting the Hare AND THE FOX . . . . . . . . . . 215

\section{CHAPTER XVI}

With the Belvoir from Coston Covert to Woodwell HEAD

\section{CHAPTER XVII}

Notes from the Belvoir Kennel . . . . . $2+3$ 


\section{LIST OF PLATES}

Belvoir and Quorn Combined Hunt .

Frontispiece

From a picture in the possession of Lady GreEnALL.

A Flying Start from Folkingham Little Gorse.

ON THE GRASS

To face page 44

By permission of the proprietors of The Graphic.

The Duke of Beaufort's Vaulter . . . . " 72

From a picture in the possession of the DUKE OF BEAUFORT, M.F.H.

Folkingham Brook. By Folkingham Windilll I I 4

By permission of the proprietors of The Graphic.

Sir Gilbert Greenall and the Belvoir Hounds. Leaving Belvoir KenNels . $\cdot$. $\cdot$.
From a picture in the possession of Sir Gilbert GreEnALL, M.F.H.

A Hunt with Sir Gilbert Greenall and the Belvoir Hounds. Away from the Griffs .

From a picture in the possession of Sir GrLbERT GREENALL, M.F.H.

The Venture: Scarborough to Bridlington.

From a picture in the possession of Mr. Lewis PRIESTMAN, M.F.H.

A Hunt with Sir Gilbert Greenall and the

Belvolr Hounds. Away for Melton Spinney

From a picture in the possession of Sir GILBERT GREENALL, M.F.H.

ON the Benches AT Belyorr

A Hunt with Sir Gilbert Greenall and the Belvoir Hounds. The Kill . . .

From a picture in the possession of Sir GILBERT GREENALL, M.F.H. 



\title{
GOOD SPOR T
}

\section{CHAPTER I}

\author{
PETERBOROUGH MEMORIES, I88I-I909
}

Peterborough the shrine of the foxhound-The foxhound described by Canon Kingsley and Lord Willoughby de Broke-Mr. Henry Chaplin's opinion of the foxhound-A standard established-Mr. Tom Parrington founder of the foxhound show-Mrs. Chaworth Musters' book-Mr. William Barford establishes the show at Peterborough-The Rev. Cecil Legard, founder of the Foxhound Stud Book-Names of the show committee-Mr. R. B. Walker, janitor of the ring-Some few people in the gathering-Famous huntsmen of the past-Some famous writers on foxhounds-Lord Willoughby de Broke's opinion on make and shape-George Carter and Tom Whitemore winning in $188 \mathbf{I}-M \mathrm{r}$. T. T. Drake and the famous Duster-The Oakley, the Pytchley, and the Fitzwilliam at the top in $188 \mathrm{I}$-Will Goodall, junior-Old George Carter in his glory with the stout Milton blood-Forty-three years ${ }^{*}$ service at Milton-Will Barnard revives the triumphs of the Milton kennel-The Duke of Beaufort-Will Dale and the Badminton winners-Tom Whitemore of the Oakley and his son George of the Atherstone-Mr. Gerald Hardy's skill in breeding hounds for the Atherstone and the Meynell-Hounds descended from Hugo Meynell's pack win in 1908-Meynell Warrener ('o7) and Why Not ('o5) - The late Lord Willoughby de Broke and the Warwickshire-Warwickshire Hermit ('89) and Jack Boore-Mr. C.B.E. Wright's opinion on markings-Warwickshire Pedlar ('or) Lord Willoughby de Broke's opinion on good looks-Jack Brown in his glory with Warwickshire Traveller ('o3) and Wizard ('o6)Mr. John Watson's last appearance at Peterbororgh-The Pytchley Marquis ('99) and Potentate ('97) - The great picture of Peterborough hound show of 1899-A visit to John Isaac in kennel-Mr. Fernie's on the flags-The Leicestershire packs and showing-The Quorn Dreamer ('87) and Tom Firr-Yorkshire packs-Mr. George Lane Fox, master of the Bramham Moor-Colonel Anstruther Thomson-Lord Middleton's-The Holderness and Mr. Arthur Wilson-The Cleveland-The Marquis of Zetland's-The Badsworth-Earl Fitzwilliam's-Craven Vagabond ('94)-Mr. Reginald Corbet's South Cheshire bitches-Lord Lonsdale's purchaseHertfordshire Sampler ('o6)-Will Wells and his admirers-The 
Meynell Why Not, a foundling-Mr. Charles McNeill and the North Cotswold Pilgrim and Piteous (05)-Sir John Hume Campbell's purchase-The Croome-Lord Manvers and the Rufford-Lord Bathurst and the V. W. H. Stentor ('o3)-The 5oth or Jubilee foxhound show, 1909-The speech of the President, Earl Fitzwilliam-Winning hounds and kennels-A sentiment from the President.

"On the straightest of legs and the roundest of feet, With ribs like a frigate his timbers to meet, With a fashion and fling and a form so complete,

That to see him dance over the flags is a treat!"

-Major G. J. Whyte-Melville.

Peterborough is a name associated with the modern foxhound in the same way that Leicestershire is inseparably linked with the history of the chase; the annual meet in July around the flags at the Peterborough Foxhound Show being regarded as the half-way house between one season and the next. The pilgrimage to this shrine of the foxhound is made by the élite of every hunting country from John o' Groat's to Land's End, inspired with the desire to act as critic upon the pick of the kennels of England.

There may be diversity of opinions as to what constitutes a good foxhound, but there can only be one as regards perfection of outline. The ideal hound is balanced and symmetrical, with the proportions of a beautiful Greek statue, every line being suggestive of grace, strength, and speed. Elegance of neck and shoulders delight the eye of the painter, while the strength of back and loins are suggestive of work and stamina. We go to Peterborough to see the best blood of the day win the ribbons, and that of Belvoir generally proves to be the trump card put forward by many a kennel hailing hundreds of miles away from Leicestershire.

The perfect lines and symmetry of the foxhound 
inspired the pen of that earnest poet and sportsman the late Canon Kingsley, who describes him in the following fine passage: "The result of nature, not limited, but developed by high civilisation. Next to an old Greek statue there are few such combinations of grace and strength as in a fine foxhound. Majesty is the only word, for if he were ten feet high instead of twenty-three inches, with what animal on earth could you compare him ? It is joy to see such perfection alive." The same sentiment was echoed by the present Lord Willoughby de Broke, speaking at a meeting of the Warwickshire hunt in the autumn of I908, when he said: "We have in these islands one of the finest classes of horses the world ever produced. With the possible exception of a thoroughbred foxhound, there is no more noble animal than the thoroughbred horse."

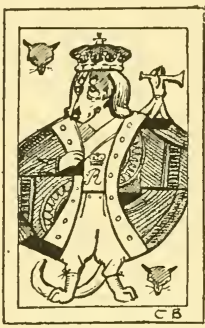

A trump card.

Mr. Henry Chaplin, master of the famous Blankney and Burton hunts in the seventies, also drew comparisons between horse and hound when he said, "Excess of bone development in a race-horse or a foxhound may amount to vulgarity." Both are aristocrats of their respective species, and must be regarded as triumphs of breeding.

Such a gathering gives us a comprehensive view of the following of the chase, a convincing proof of the reality of fox-hunting, which has proved a power for good, and helped to mould the character of the nation. The standard of excellence set on the flags at Peterborough has undoubtedly fostered the ambition to breed better hounds throughout the country, for every year fresh kennels put forward candidates to compete for honours. The solemn assembly of 
expert opinion gathered around the ring is there to discuss knotty points in breeding, and the result, with time and experience, has evolved that beautiful weapon of the chase the modern foxhound, in whose veins courses the "blood" of Belvoir, Badminton, Brocklesby, or Fitzwilliam.

A wealth of reminiscences are associated with visits to Peterborough, which is the premier event of the foxhounds of Great Britain, an institution honoured by the patronage of King Edward VII. The founder of the foxhound show must be regarded as Mr. Tom Parrington, who was master of the Sinnington Hunt when a trencher-fed pack, from I879 to I884. Happily he is with us to-day, and his appearance at Peterborough as judge, or making a speech at the luncheon, is the signal for a great ovation, led by the huntsmen in uniform sitting at the "scarlet table." As far back as I859 it is on record that the Fitzwilliam hounds went to Redcar and won with Hardwick and Friendly at the first hound show open to all England.

In a "Book of Hunting Songs and Sport," collected by Mrs. Chaworth Musters and dedicated to the Right Hon. Earl Ferrers, MI.F.H., published in I885, there are some amusing verses on the show of foxhounds at Osberton, about 1825, written by Mr. Hodgson of the Holderness to Mr. Wicksted, master in "the Woore country." The prizes were a horn for the master, a saddle and broadcloth for coats for the men.

In 1879 , or thirty-one years ago, the hound show was transferred from Yorkshire to Peterborough and held in connection with the Agricultural Showthanks to the enterprise of the late Mr. William Barford, who for many years was Chairman, and to-day is succeeded by his son, Mr. James Barford, 
an indefatigable worker in the interests of both sides of the show.

There is no one more widely known at the Peterborough gatherings than the Rev. Cecil Legard, vicar of a small parish in Northamptonshire and heir to a Yorkshire baronetcy. Clad in faultless clerical attire, his judgment on horse and hound is safe as St. Paul's. As the founder and editor of the "Foxhound Kennel Stud Book," Mr. Legard has accomplished a great work to further the interests of the chase, and every year presents a silver huntinghorn at the Peterborough show for the best unentered dog-hound. At Belvoir his reverence is very well known, having judged every entry of young hounds since Sir Gilbert Greenall instituted the puppy show. A few years ago Mr. Legard was presented with his portrait by the Association of Masters of Foxhounds, when retiring from the editorship of the Stud Book, which is now undertaken by Mr. H. E. Preston, joint-master of the York and Ainsty with Mr. E. Lycett Green. As a prominent official of the show, the Marquis of Huntly is always to be seen there, and a latterday member of the committee is the young Marquis of Exeter, one of the keenest amateur huntsmen of his time. Mr. J. L. Mills, Major G. L. Wickham, Colonel Henry Wickham, and the Chairman, Mr. G. C. W. Fitzwilliam, figure prominently in the management of the show, aided by Mr. J. G. Barford, Mr. J. W. Buckle, son of the famous jockey, Mr. J. C. Cheney, Mr. J. Crisp, Mr. W. G. Maxwell, Mr. F. Percival, a name of Heycock fame in the Fitzwilliam country, Mr. R. B. Walker, with Mr. John R. Smart, the indefatigable secretary. A prominent figure managing the arrangements of the ring and announcing the verdict of the judges is 
Mr. R. B. Walker, who has done so for nearly a quarter of a century. Amongst the distinguished gathering have been seen at one time or another Sir Reginald Graham, the Yorkshire squire, exmaster of the Cotswold, New Forest, Tedworth, and Hurworth hunts, and author of a most interesting volume of "Hunting Recollections," which we had the pleasure to help to illustrate; the late Sir Herbert Langham, of Pytchley fame, often judging hounds; Mr. G. P. Elystan Evans, ex-master of the Cambridgeshire and Tickham hunts, also a judge at Peterborough; Mr. T. Butt Miller, master of the far-famed V. W. H. Crickdale; "Brooksby" of the Fiell, Captain Penell Elmhirst, Lord Annally, Mr. C. D. Seymour, Mr. Alfred Gilbey, Colonel Robertson Aikman, Lord Westmorland, Mr. W. E. Oakley, Lord Penrhyn, the Earl of Enniskillen, Lord Chesham, Sir William Cooke, Mr. Sidney Loder, Mr. H. W. Selby-Lowndes, Mr. Robert Watson, and his son Mr. John Watson, Lord Bathurst, Lord Leconsfield, Mr. Esmé Arkwright, Lord Waterford, Lord Cholmondeley, the Hon. Mark Rolle, Mr. Merthyr and Lady Theodore Guest, Mr. R. Chandos Pole, Mr. and Mrs. C. Penn-Sherbrooke, Mr. J. S. H. Fullerton, Sir W. M. Curtis, Lord Southampton, Mr. W. M. Wroughton, Mr. J. Maunsell Richardson, Lord Macclesfield, Mr. J. Bathurst are a few names, past and present, that help to make a Peterborough crowd of celebrities, together with as many fair ladies in summer costume, the Dianas of the chase, from hunting countries far and wide.

Memories of famous huntsmen seen round the ring, either as professors in mufti or wearing the uniform of the chase, calls to mind two or three generations, the record of whose science and skill form the brightest pages in hunting history. We 
might mention Frank Goodall of the Queen's ; Charles Payne from Sir Watkin Wynn's; Frank Beers from the Duke of Grafton's; Nimrod Long from the Badminton; Tom Smith of the Bramham Moor; John Jones, for over twenty years huntsman to the Cheshire; Cox of the Bicester; Charles Leadham of the Meynell ; and Frank Gillard, late of the Belvoir, whose opinion on hounds to-day is in great request.

Those whose names are known best as the scribes on foxhound lore, compiling a valuable record of the greatest assistance to breeders to-day, include the late Mr. G. S. Lowe, perhaps the best writer of the century on foxhound breeding; Mr. Miles, our old friend "Dragon " of Horse and Hound, always to be seen sitting "in the poets' corner" at Peterborough; Captain Pennell Elmhirst, the Prince of hunt correspondents, "Brooksby" of the Field; Mr. Charles Richardson, "Shotley" of the Field, an authority on all branches of sport; Mr. Crawford Wood, one of the most polished and brilliant performers with the pen in the pages of the Field under the nom de plume of "Hyme"; Mr. Scarth Dixon, a great Yorkshire authority on fox-hunting, son of the famous "Druid" and brother of "Vigilant" of the Sportsman; the Hon. J. Bathurst, a former master of hounds and editor of Land and Water; the Rev. T. F. Dale, also a former editor of the same paper and a prolific writer of hunt history; Mr. Otho Paget, well known as "Q." of the Field for Leicestershire.

The late Lord Willoughby de Broke was strong in his arguments against those who do not love hound shows, where shoulders, necks, and forelegs -indicative of speed-are in strong demand. Those who think that pace, make, and shape are synonymous with wildness are past arguing with. Wild- 
ness is as common in the slow as in the fast, and has nothing whatever to do with make and shape, or with nose either. Not only is pace an assistance indirectly to the nose of a hound, but make and shape are a direct assistance to the nose of any hunting animal. Make and shape indicate ease of motion-a smooth, even action-and therefore wind, without which none of the senses can be utilised to the full. Still, in spite of any argument, there will always be those to subscribe to the old copy-book maxim, "It is better to be good than beautiful."

Early memories of Peterborough are associated with the tall figure of George Carter, who for a number of years was well-nigh invincible with the stout Milton blood from Mr. Fitzwilliam's kennel. The keenest rivalry in the ring existed between George Carter and Tom Whitemore, a contrast in height and figure, who ran him very close with the pick of the Oakley, both claimed by Peterborough men as home packs. Our first hound-show notes were made in I88I and published in the Illustrated Sporting and Dramatic News. Twenty-one kennels sent entries on that occasion, and the show was held in the open on the skating rink, the judges being the late Lord Portsmouth, a student of all the best lines of blood from the days of Hugo Meynell; Mr. T. T. Drake, master of the Bicester, a name for all time associated with the illustrious race of old Duster, whose blood runs in many of the most famous sires of to-day; and Mr. R. D. Scratton, master of the Essex Union, afterwards a great breeder of short-horns. Both Mr. Drake and Mr. Scratton wore tall silk hats in the judging ring.

The first class for the best couple of unentered dog-hounds took some deliberation and weeding out 
from the fourteen couple paraded before the judges. Lord Portsmouth and his colleagues were in favour of a big hound, and finally, amid loud cheers, handed the blue riband to Tom Whitemore for the Oakley, the first couple being Leader, by Lasher out of Wrathful, daughter of Fitzwilliam Wrangler; and Flyer, by the Atherstone Traitor out of Flora, who was by Fitzwilliam Furrier. The Pytchley were second, shown by young Will Goodall, who was brought up by Sir Thomas Whichcote at Aswarby Park, and graduated at Belvoir under his father the famous Will Goodall and Frank Gillard. In the next class for two couple of entered hounds, George Carter had the consolation of knowing that the old blood so dear to him and Tom Seabright would still tell. The Fitzwilliam found favour at once in the eyes of the judges, winning with the six-season Sultan, by old Selim out of Rosamond, daughter of Seaman; the four-season Selina, by Somerset out of Benefit; Roman, by Wrangler from a daughter of Rubicon; and the five-season Wellington by Wrangler from a daughter of the famous Tarquin. For second place there was keen competition between the Oakley, the Atherstone, and the second Milton team, consisting of Nigel, Senator, Reveller, and Wanderer. When both the blue and the red riband were handed to George Carter by the judges, a smile of triumph spread across his genial face which defied all efforts at self-control, the spectators cheering "the booted giant" to the echo.

For style and power there was no getting away from the stout Milton blood, Selim being adjudged the best stallion hound in the show, the red riband going to George Castleman for Atherstone Solon. Much merriment was caused amongst the professional talent looking on when first prize was awarded 
to the Warwickshire for two couple of bitches, and Carter led his out of the ring as though caring nothing about second place. When brought back again to receive the red riband, there was plenty of chaff flying about, but the laugh was with him, for he presented the appearance of a recruiting sergeant decorated all over with winning ribands.

Poor old George Carter had a good innings at Milton. Coming into the service of the Fitzwilliam family in $\mathrm{I} 845$ at $£ \mathrm{I} 2$ a year as whipper-in under Tom Seabright, he completed forty-three years' service, and died in 1889 quite a rich man, leaving $£$ I7, 00o behind him.

The mantle of Elijah has fallen on the shoulders of Will Barnard, the present huntsman to Mr. George Fitzwilliam, who came to Milton in I900, and repeats history, for he too is decorated with winning ribands on every show occasion, like his former commander-in-chief. Will Barnard is the right man in the right place, for early in life he rode whipper-in at Milton for four seasons under George Carter, and worked in harmony with the old huntsman. Since the present master, Mr. George Fitzwilliam, has undertaken the management of the family pack, to the joy of the whole country-side, he has entered heart and soul into the duties of the field and the breeding of the kennel. The old strains so famous in the past for nose, tongue, and drive have been bred up to, and the type of hound now found in the kennel has the size, bone, and quality of those which made the woodlands ring with melody in the seventies and eighties when George Carter was invincible. We have had the pleasure of a hunt with Mr. George Fitzwilliam's hounds on one or two occasions, and there is no keener master. Amongst the many winners in the 
kennel to-day, the names of the three hounds which have won champion honours will do for mention. These are the big dog Harper ('o3) by Atherstone Harper ('97) from Tynedale Ardent ('97). Mr. H. E. Preston and Mr. J. M. Richardson placed this dog in front of everything at the show of I905, his size, quality, and breeding making him a most valuable stud hound. In I906 the beautiful bitch Sanguine ('04) by Analyst ('98) from Sacred ('97) was the best of the ladies in the opinion of the two judges, Mr. G. P. Evans and Mr. W. M. Wroughton. Coming to I9o8 the Fitzwilliam blood was again pre-eminent with Donovan ('05) by Dorset, from Luxury by Wentworth Gambler, a big tan and white hound on the best of feet and legs, his ears being unrounded as of old.

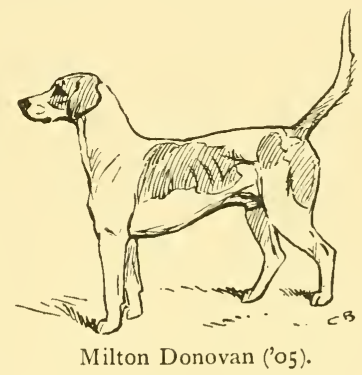
Champion honours were awarded to Donovan by Mr. J. A. Radcliffe and Mr. W. M. Dunn.

The present Duke of Beaufort has hardly missed a Peterborough show during the thirty-one years of its existence, the tallest master of hounds on the active list and the first gentleman huntsman of his time. From ninety to a hundred couple are wanted for the magnificent hunting establishment at Badminton, with its seven and sometimes eight days a week, two packs being frequently out on the same day_the Duke hunting one and Will Dale the other. The Badminton blood is one of the chosen sources for improvement, and nicks with the Belvoir, the Brocklesby, and Fitzwilliam. From time to time the pack has been strengthened by purchases of 
fresh blood, a high standard being maintained, the Badminton sires coming into the pedigrees of many winners for other kennels. In I899 the Duke of Beaufort's won several prizes at Peterborough, the best two couple being Victor, Raglan, Ringwood, and Woldsman, by Belvoir sires from Mr. Austin Mackenzie's bitches. The best stallion hound this year also hailed from Badminton, being a nice muscular dog with beautiful quality and bone, named Vaulter ('97) by Belvoir Vaulter, the judges

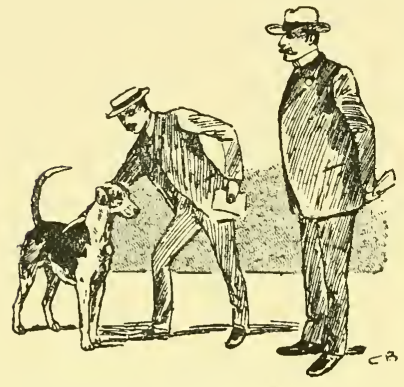

Mr. Austin Mackenzie, M.F.H., and the Earl of Enniskillen, M.F.H.

being the Earl of Enniskillen and Mr. Austin Mackenzie. On the same afternoon the other set of judges, the Rev. Cecil Legard and Mr. John Williams, awarded champion honours to the Duke of Beaufort's Rapture ('98), a pied bitch typical of the old Badminton sort.

Coming to the events of I904, a blend of the new and old Badminton blood worked out top in the ladies' class, Drapery, Drosky, Dagmar, and Lightly winning for two couples, the judges being Mr. C. B. Wright and Mr. J. C. Straker.

Will Dale, wearing the green uniform of the Badminton, is one of the tallest huntsmen of his day, and won his reputation when at Brocklesby with the Earl of Yarborough. Keen and genial, hunting is the foremost passion of his heart, for he never gives the Gloucestershire foxes any rest, and ends the season with a bigger score than any other huntsman in England.

The late Tom Whitemore, with his snow-white 
hair and thoughtful countenance, nearly always had a winning hand when showing for the Oakley during the mastership of the late Mr. Robert Arkwright. Amongst many winners which have done well afterwards, we may mention Oakley Dancer ('88) by Grafton Dancer, from Redcap by Regent, a handsome dog, of exceptional character in his work, without a single weak point in his pedigree. Sir Reginald Graham and Sir Herbert Langham placed Oakley Dancer at the top of the dog-hounds at Peterborough in I8g. I.

In later years the Whitemores, father and son, often met in rivalry on the flags, young George being huntsman to Mr. Austin Mackenzie's Woodland Pytchley pack, afterwards going to the Atherstone under Mr. Gerald Hardy, from which kennel he put forward a sequence of winners.

When seeking improvement, Mr. Gerald Hardy has gone solid for Belvoir sires and done well, breeding hounds in the Atherstone kennel of a medium size, beautiful in style and colour, able to drive through the fences of a cramped country. At Peterborough they have a very long list of honours to their credit, winning the championship with Challenger (' 98 ) in 1902, the judges being Mr. T. Butt Miller and Mr. C. B. E. Wright. The Whitemores often came together for the final, and when the old man's candidate was beaten by his son's, much to the merriment of the huntsmen looking on, he used to say, "Ah well, I had to let the boy have it this time!"

Mr. Gerald Hardy's name has latterly been associated with the revival of a famous period of past hunting history - the appearance at Peterborough of young dog-hounds from the Meynell kennel, where he is now master. Descended from the hounds of 
Hugo Meynell, the first to hunt in Leicestershire, the latter-day triumphs in breeding are the result of a dip into the Belvoir blood. Mr. Gerald Hardy and his huntsman Charles Gillson have good cause to be proud of Warrener and Why Not, winners at Peterborough in 1907 and I908. To describe Meynell Warrener ('07), by Belvoir Warlaby from Locket, he has size to recommend him, standing nearly $24 \frac{1}{2}$ inches, and measuring 32 inches round the heart. All activity, well coupled up, with shoulders, ribs, legs, and feet of the best, the breeding of his sire and dam, nick through Belvoir Weathergage (' 76$)$, and his colour is typical of that kennel.

Of Why Not ('05) Charles Gillson said, " $\mathrm{He}$ is quite a huntsman's hound in the field," a stylish, tan-coloured dog by Belvoir Vagabond ('99) from South Cheshire Wayward, a daughter of Warwickshire Talisman. Why Not was bred by Mr. Reginald Corbet when master of the South Cheshire, who kept nothing but bitches, presenting the dog puppies to his friends. Both Warrener and Why Not helped the Meynell to win in the class for the best two couple of dog-hounds in Igo8.

The Warwickshire, under two masterships of Lord Willoughby de Broke's, have gained probably more distinctions on the flags than any other pack of hounds in England, and that too in a very short space of time. The late Lord Willoughby de Broke, with Jack Boore as huntsman, advised by Mr. J. Maunsell Richardson and the Rev. Cecil Legard, built up the kennel with liberal infusions of blood from the Belvoir, Milton, and other proven sources, determined to make the pack the very first for high quality. In $\mathrm{I}_{9} 2 \mathrm{2}$ the Warwickshire sent a very beautiful dog to Peterborough in Hermit ('\$9), who 
PETERBOROUGH MEMORIES, I88r-Ig09

defeated all comers, and was destined to become a great sire, his young stock winning in both classes on the occasion under consideration. Hermit ('89) was by Harper, a celebrated Warwickshire sire, from Ruthless by Ravager, and he looked the gentleman all over, it being impossible for a lover of fashion

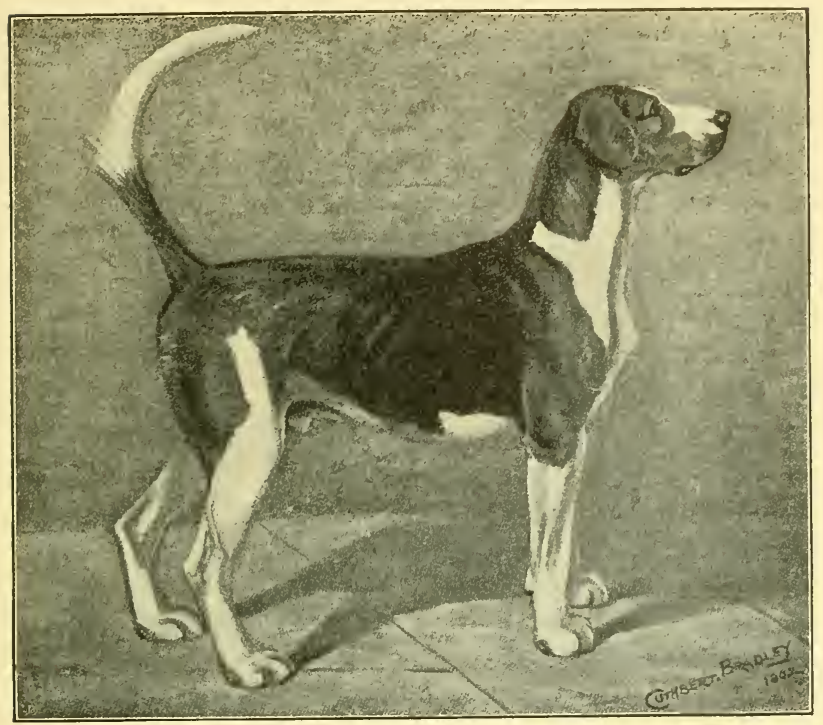

Atherstone Challenger ('98)-Champion 1902.

to get away from the beauty of his neck and shoulders. He had a thin white stern with very little feather, carrying it well over his quarters, the weak point in his conformation being a slackness in the back ribs. The judges were Mr. C. B. E. Wright, master and huntsman of the Badsworth, and Mr. E. P. Rawnsley, master and huntsman of the Southwold, and this was the last occasion at Peterborough when one set of judges were able to get through 
the arduous duties of judging both classes. A remark made by Mr. Wright about colouring we well remember, "In breeding hounds take care of the white necks and shoulders." Certainly Hermit was a case in point, his markings enhancing his marvellous symmetry.

A full record of Warwickshire triumphs would fill a whole chapter, for they have been continuousTancred winning the champion prize in 1897 ; but to come to the events of Igor, of which year we

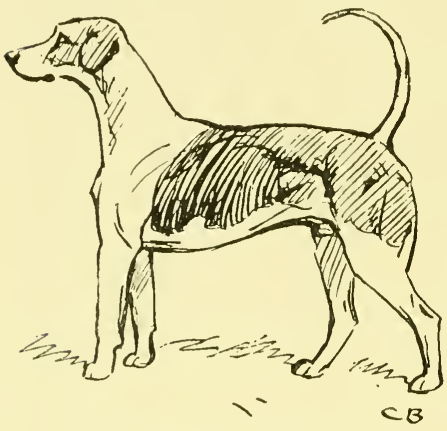

Warwickshire Hermit ('sq). have pleasant memories about Pedlar, the last of the late Lord Willoughby de Broke's prize-bred hounds. Pedlar ('or), by Tuscan from Heedful, strained back on both sides to Belvoir Weathergage, before he had seen a fox, won the champion prize at Peterborough, shown by Jack Brown, a noted hard rider from Lord Harrington's country, succeeding Jack Boore.

Standing $23 \frac{1}{2}$ inches high, with muscular back and quarters, Pedlar lacked the elegance of neck and shoulders which distinguishes Warwickshire winners, and Lord Willoughby de Broke pointed this out as he painted Pedlar's portrait. Though, alas, a confirmed invalid, wheeled in a bath-chair to the kennels, the noble master talked away about hounds and hunting, one of his trite sayings being, "A foxhound should be good-looking, well-made, and able in the field as a matter of course." The judges in 
Pedlar's year were Mr. R. Chandos-Pole and the Hon. C. Brand.

During Jack Brown's reign as huntsman to the present Lord Willoughby de Broke, he made a great hit with two young dogs, Traveller ('o3) and Wizard ('o6), who came up to the high standard shown by the Warwickshire. The first of these, Traveller, winner of the champion prize in I904, was a hound with a distinguishing white stern, like Hermit had, his sire being Belvoir Handel and his dam Tragedy, the daughter of the famous Talisman. He looked the foxhound in every line, combining substance with quality, with a beautiful carriage, and the best of feet. Three years later Jack Brown was in his glory, as he walked into the ring wearing one boot and a legging to win another champion prize with Wizard ('06), a dark-coloured hound, by Tuner from Wilful, the daughter of Tudor. The same day Traveller also won as the best stallion hound, after a hard tussle with Atherstone Conquest, the runnerup, and the occasion will long be remembered by the regular Peterborough goers. Mr. Charles McNeill, master of the North Cotswold, and Mr. Gerald Hardy, master of the Meynell, were the judges, going for symmetry and style in preference to bone and size. Jack Brown stood chewing a bit of biscuit, smiling into the hound's face; Traveller giving a marvellous show of his blood-like quality in statuesque pose. A very amusing description of the scene was given by Pomponius Ego in the pages of Vanity Fair, from which we give an extract: "Personally, I should have bestowed the sire's prize upon the Warwickshire Traveller, because he raised a rippling laugh, and bent a beam of humour upon the scene-no hound at Peterborough has ever before realised the true dignity of 
the occasion as Traveller did. For minutes he stood as a statue graven in stone, with never a movement in his taut-drawn muscles. The best sire of our generation was magnificently upheld in the noble dignity and serene contempt he displayed for the other 'dogs' who brushed his flanks and with inquisitive nose examined this mould of fashion and glass of form."

The two judges being unable to divide their opinion between Traveller and the Atherstone Conquest, Mr. John Watson, master of the Meath, was called in as referee, and after bestowing critical glances on the couple, he slapped Traveller with his catalogue and said, "I go for this dog!"-confirming his opinion of 1904 when, with Mr. W. M. Dunn, he awarded this Warwickshire dog the championship. Alas, this was the last time the late Mr. John Watson was seen at Peterborough, where he was known so well judging horses and hounds; he was one of the house-party entertained by Mr. and Mrs. George Fitzwilliam for the Milton puppy show, which takes place the day before the hound show.

The Pytchley, the admitted best four-day-a-week country in England, has done well at Peterborough in the past, winning the champion honours in I893 for dog-hounds with Forager ('93) by Rockwood, in the mastership of Lord Spencer, with Will Goodall, huntsman, the judges being Sir W. M. Curtis, Mr. T. H. Ashton, and the Rev. Cecil Legard. Coming to a later date, in the mastership of Mr. W. M. Wroughton, a successful student of hound breeding, with John Isaac as huntsman, the Pytchley were keen competitors, winning the champion prize in I899 with Marquis ('99), unrounded, and a longcoupled tan dog, by Belvoir Dexter from Mayoress, 
a daughter of Oakley Dancer, the judges being the Earl of Enniskillen and Mr. Austin Mackenzie. The following year, I9oo, the Pytchley had another champion win with Potentate ('97), by Belvoir Gordon from Parable by Oakley Dancer, the judges being Mr. G. P. E. Evans and Mr. W. E. Rigden.

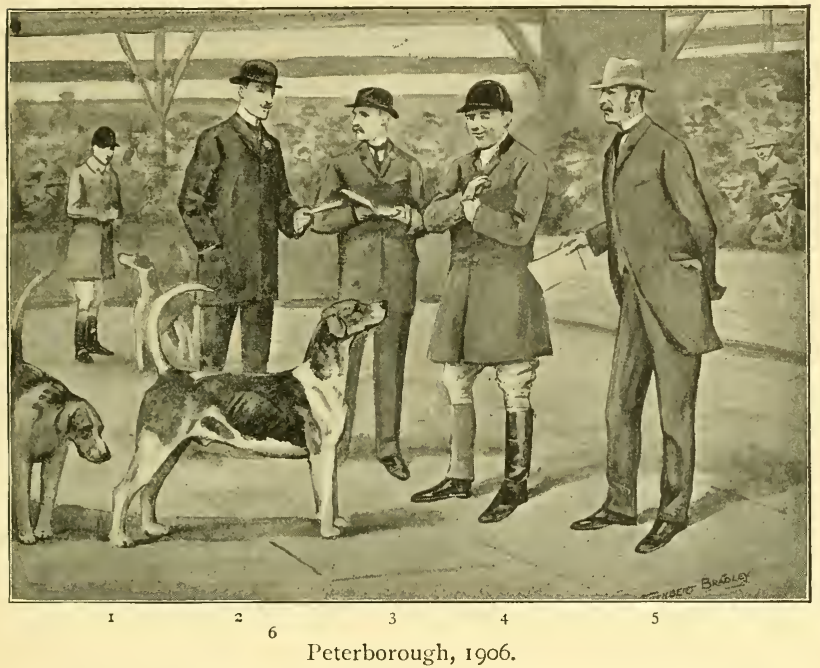

I, George Whitemore ; 2, Mr. Charles McNeill, M.F.H. ; 3, Mr. Gerald Hardy, M.F.H. ; 4, Jack Brown; 5, Mr. John Watson, M.F.H. ; 6, Warwickshire Traveller.

Potentate was an upstanding, determined-looking dog, with good shoulders, and well ribbed up; in type and colouring he was typically Belvoir, and that kennel used him. The Pytchley stood high in IS99 with Potentate, Marksman, Miner, and Pageant, two couple of dog-hounds placed second to the Duke of Beaufort's two couple, Victor, Raglan, Ringwood, and Woldsman, all by Belvoir sires. They appear in the large picture of Peterborough 
published by Messrs. Dickinson of Bond Street in I9oo, for which we paid a visit to Badminton and Althorp to make studies in kennel, half life-size.

When showing on the flags, John Isaac had all the action of a conjurer or a mesmerist, a marvellous knack of bringing out the best points of a hound. On going to kennels, Isaac met us with the tragic news that one of the hounds, Marksman, was dead. "I had him skinned, so that you might see his colouring," he said by way of consolation. "What style of hound was he in life, and how did he carry

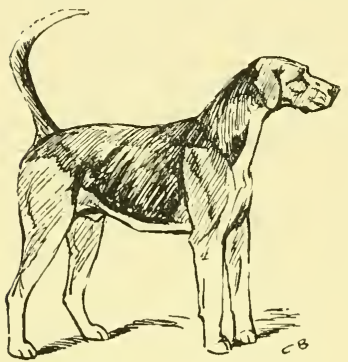

Pytchley Potentate ('97). himself?" we asked, wishing to revive a Peterborough memory. "I'll soon show you, sir; a little big dog, that set himself like this," replied Isaacs, as he seized the skin and, with his hands underneath, performed a juggling trick which seemed to almost animate it into life. Fortunately there was a photograph of Marksman, which had to serve for the picture!

Mr. Fernie's beautiful Leicestershire pack is another which has always stood high with the judges, and a succession of winners have been put forward by Charles Isaac, brother to the Pytchley huntsman. Atherstone and Belvoir are the favoured sources for blood, and in 1906, amongst other honours, two couple of dog-hounds from Mr. Fernie's were placed second in a very strong class, which was headed by the Warwickshire quartette, including the champions Traveller and Wizard. Mr. Fernie's Ferryman ('03), who has been seen out at Peterborough, is a dog by Harlequin, from Fealty 
by Belvoir Falcon, possessing the blood of Quorn Alfred ('72), a hound greatly bred from by Tom Firr, and his stock were wonderfully good in many kennels, able to race a fox as well as hunt one.

One might imagine that Leicestershire, the first hunting county in the world, portioned between four or five different hunts, would have the hounds to sweep the board of prizes. But, excepting Mr. Fernie's, Leicestershire does not count on the flags. As is well known, the Duke of Rutland's, the acknowledged premier pack of the day, has never shown away from Belvoir, though all the masters and experts in breeding spend a day on the flags of that kennel, "to tone up a foxhound eye and foxhound memory," before visiting Peterborough. Though Belvoir does not enter into competition, it is their blood which wins the majority of prizes for other kennels. The Quorn and the Cottesmore have been seen out very seldom, and the same may be said of Lord Harrington's hounds hunting a slice of Leicestershire country.

The Quorn with Tom Firr, in the time of Captain Warner's mastership, went to Peterborough, the most successful year being I890, when they won the champion cup with Dreamer ('87), a lemon-andwhite-coloured hound, built on racing lines, showing elegance of neck and shoulders. Tom Firr was one who bred for pace as the first essential for the Quorn pack, and Dreamer was by Rufford Galliard, from Dorcas by Comos. Another hound from the same kennel won this year in the novice class, Sampson ('90), by Belvoir Gambler from Charmer, a daughter of Rallywood, a massive young dog with Belvoir colouring. The judges on this occasion were Mr. P. A. W. Carnegy, Mr. Reginald Chandos-Pole, and Mr. Thomas Parrington. At the 
luncheon Firr made a speech of neatly-rounded sentences well delivered, for he was a man of many parts, a good musician, and gifted with artistic instincts.

When there was a class at Peterborough for hunt fox-terriers, Tom Firr and Frank Gillard were to be seen judging them in a side wing. The day these little "yappers" were banished from the hound show came as a great relief to everybody who hates noise.

Yorkshire was represented for many years at

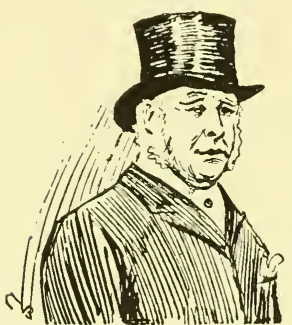

Mr. George Lane-Fox, M.F.H.

Peterborough by the commanding form of the late Mr. George Lane-Fox-as familiar on the box of a coach at Hyde Park, or as a critic at all important horse shows, as he was to the followers of the far-famed Bramham Moor. The "grand old Yorkshire squire," to give him his familiar title, stood six feet in his stockings, erect as a pine-tree, was one of the old school in dress and deportment, a model landlord, master of the Bramham Moor for fortyeight years, and it was a proud boast that he had never been out of England. Near to Mr. George Lane-Fox was generally to be seen his friend and contemporary--a match in height and keenness for hounds-Colonel Anstruther Thomson, whose laurels were won in the Fife, Bicester, Pytchley, and Atherstone counties, and whose reputation extends from north to south.

Lord Middleton to-day is a regular attendant at Peterborough, but representatives of his famous Yorkshire pack of medium-sized hounds, descended from those bred by Sir Tatton Sykes, are seldom seen showing. 
One of the Yorkshire kennels which have done best of late years is the Holderness, under the late mastership of Mr. Arthur Wilson of Tranby Croft, with IV. Metcalf huntsman. In 1902 their Handel ('02) by Belvoir Handel, and their Dasher ('O2) by Belvoir Dasher, won three prizes in good company, whilst in the lady class Holderness Sanguine by Barrister from Stella won the champion prize and was a nicely-turned bitch, showing the characteristic solid black colouring of the kennel, edged with tan and white only on the extremities.

The Cleveland, another famous pack from the large-acred county, under Mr. W. H. A. Wharton's mastership, has been a constant exhibitor and won many prizes. The Marquis of Zetland's beautiful pack, strengthened by Belvoir drafts, are well known at Peterborough, with old Bridger Champion, the white-bearded huntsman, showing them. The Badsworth in Mr. John S. H. Fullerton's mastership, I895 to I902, scored a win with a nice dog, Finisher by Belvoir Dexter.

Earl Fitzwilliam's Yorkshire pack, with Frank Bartlett showing, won for two couple of dog-hounds in I897, these being Duster, Reveller, Damper, and Glancer. The judges this year were Mr. W. E. Rigden and Mr. H. E. Preston, who awarded the championship to Warwickshire Tancred.

In I894 the Craven Vagabond ('94) made quite a sensation by coming out top of everything, to the delight of "a hunt resting in the membership of excellent sportsmen descended from county families." This young dog, who was destined to make a great name for himself as a sire, was by Warwickshire Hermit - whose win we have mentioned-from Volatile, the daughter of Rustic, also winning in a class for two couples with three others of the same litter, 
and was bred by Lieut.-Col. G. C. Ricardo. Displaying the elegance of neck and shoulders shown by his sire, he possessed beautiful quality and bone, captivating the eye of the judges, who were Sir Bache Cunard, Mr. John Watson, and Mr. W. H. A. Wharton.

Amongst those who have only kept bitch packs to hunt with and done well at Peterborough, the South Cheshire are a notable example, under the mastership of the Messrs. Corbet, father and son. South Cheshire Tarnish, Triumph, Testy, and Trilbyall I9o2 entry-will be remembered amongst other celebrities, and to-day are the matrons in the private pack at Barleythorpe, hunted by the Earl of Lonsdale, who purchased, for over $£ 3000$, twenty-five couple, when Mr. Corbet retired. One of the dog puppies bred in the South Cheshire kennel and given by Mr. Reginald Corbet to Mr. Fenwick Harrison, master of the Hertfordshire Hunt, when a two-day-old whelp, grew to be the "top dog" at Peterborough, 1907.

Hertfordshire Sampler ('o6) by Mr. Wroughton's Spanker, from South Cheshire Tarnish, possesses the blood of many great hounds seen during the past twenty-five years, there being nothing to beat his breeding. He stands about twenty-four inches, showing the richest of Belvoir colouring. No wonder Will Wells, his huntsman, was proud, when warmly congratulated by numerous Belvoir admirers, who remembered him, "witching the world with horsemanship," as a whipper-in to the Duke of Rutland's hounds in the early eighties, a purse of money and eleven silver hunting-horns being presented when he left to go huntsman to the Puckeridge, under Mr. Gosling.

The Meynell Why Not ('05), already alluded to, 
is another instance of a foundling puppy from $\mathrm{Mr}$. Corbet's Cheshire pack winning high honours at Peterborough.

When Mr. Charles McNeill, the present master of the Grafton, had charge of the North Cotswold, he established a beautiful pack of bitches only, which were most successful when shown at both Peterborough and Reigate. Big typy bitches, all by Belvoir sires, they had the size and deep notes of dog-hounds, the pack being eventually sold to the present master, Sir John Hume Campbell, for $£ 3500$. The most successful couple were the two sisters Piteous and Pilgrim ('05) by Belvoir Handel, and in I9o8 North Cotswold Pilgrim won as the best brood bitch and champion of the show. As Dan Reid, their huntsman, says, "They are always gay and well forrard; demons on the line of a fox."

The Croome is another Worcestershire pack with a reputation-Mr. Dudley Smith, when master, using Belvoir and Warwickshire sires, the same as Lord Coventry did before him; Croome Saintly by Warwickshire Samson from Dairymaid, a daughter of Craven Vagabond, winning the champion honours for bitches in I907, the judges being Mr. John C. Straker and Mr. John Williams.

The Rufford during Lord Manvers' mastership did well with dog-hounds, the brothers Factor and Furrier ('04) by Belvoir Dasher, from Famous by Belvoir Grasper, possessing size and good looks.

For Lord Bathurst's hunt, the Vale of the White Horse, James Cooper, who is the son of a famous Belvoir huntsman and learnt his business with the late Lord Willoughby de Broke, has won many prizes, taking champion honours in IgO3 with Stentor, a very elegant dog with beautiful carriage, good bone, and the best of feet. Stentor ('O3) was 
by Belvoir Stormer, from Dahlia by Cotswold Dashwood, and his win was a notable one for a two-daya-week pack of thirty-two couples. The judges were Sir William Curtis and Mr. J. S. H. Fullerton.

Earl Fitzwilliam in his presidential speech at the luncheon, July 7, I909, reminded the large assembly that it was the jubilee of the Foxhound Society, which owed its origin in I859 to Mr. Thomas Parrington, at one time master of the Sinnington hounds when a trencher-fed pack. At the first

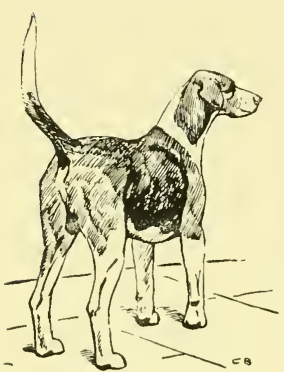

Good to follow. show, which was held at Redcar, Mr. Parrington presented a silver cup, which was won by Milton Hardwick and Friendly, shown by old Tom Seabright, who journeyed all the way from Peterborough. To celebrate the jubilee of the show, Mr. Parrington again offered a silver cup for the best couple, dog and bitch. It was a singular coincidence, commented on by the president, that again the Milton or Fitzwilliam kennel were successful, winning with Saladin and Saucebox, shown by Will Barnard, who whipped-in to the famous George Carter, who in his day was whipper-in to Tom Seabright.

A wealth of tradition and sentiment is therefore attached to the annals of hound showing, the oldestablished family packs, the pioneers of fox-hunting, holding their own to-day with the newer rivals which have sprung into existence. Unfortunately, the veteran Mr. Thomas Parrington was unable to be present to award his own cup, which would undoubtedly have been made the occasion for a great ovation at the luncheon, led by the huntsmen in scarlet sitting at the central table. 
There is abundant evidence that fifty years of foxhound competition on the flags has been the means of bringing into prominence the best qualities sought after by breeders throughout the kingdom. The names of the first winners, Wynnstay Royal, Lord Coventry's Roman, Milton Somerset, Brocklesby Ambrose, Oakley Rhymer, and many others are perpetuated in pedigrees to-day, handing down merit in foxhound blood that cannot be mistaken. This is a strong argument in favour of breeding for good looks as well as good work, the study of the extended pedigree of the winning couple of the Jubilee Cup, containing, as it does, a succession of past celebrities as evidence that like begets like.

The far-extending influence of the Peterborough show on hound-breeding may be judged by a study of the prize list on the last occasion, I909, when, in addition to the old-established winning kennels, such as the Fitzwilliam, the Warwickshire, and the Meynell, the East Kilkenny, under the mastership of Lord Southampton, sent the best single unentered bitch-hound, and the Cattistock, under the mastership of the Rev. E. A. Milne with W. Metcalf, huntsman, won the champion prize for the best bitch in the show.

In the words with which Earl Fitzwilliam concluded his presidential speech at Peterborough, we finish this brief sketch of many pleasant memories of the summer meet on the flags: "It is fifty years since the show was started, and we hope that it will be fifty times fifty before it experiences an ending." 


\section{CHAPTER II}

\section{THE QUORN AT KIRBY GATE}

An appreciation of Kirby Gate-Melton Mowbray described-The crowd of sight-seers - The influence of hunting on various undertakingsTom Firr as a houndsman-Quorn Alfred-Tom Firr the horseman -Other Quorn huntsmen-Captain Frank Forester, master of the Quorn, and his horses - Captain Burns Hartopp, ex-master; the Hon. Lancelot Lowther, deputy master- The House of Lords and foxhunting-Distinguished personages in a Kirby Gate field-The field at Kirby Gate, 1908-The splendour of the Earl of Lonsdale's mastership-Hunting fare-What Tom Firr and Frank Gillard rode on-Celebrities at Kirby Gate, I903-Mr. and Mrs. James Hornsby of Stapleford Park-The silver whistles of the Quorn -A run and mark to ground-Harry the Quorn runner-Tom Firr's whoo-whoop!

"Fill up a bumper! No hounds can go faster, No country can equal our country of Quorn.

Health and long life and success to our Master; Long may Firr flourish and carry the horn.

See through the covert the staunch hounds springing !

Hark to the halloa! Hark to the horn!

Hark to the silver whistles ringing !

Follow, follow, follow the Quorn."

-H. Cumberland Bentley.

THE opening meet of the Quorn on the first Monday in November at historic Kirby Gate acts as a curtain-raiser for another season's sport in the shires. The country-side looks forward to the pageantry of the chase on this day; its gay colouring and bright surroundings doing quite as much to keep fox-hunting in favour as any of the more sterling advantages it can boast. It is a gay scene and wholly English, one that the oldest rider to hounds can never watch unmoved. Kirby Gate 
itself is a quaint old house, standing inside a park, at one time being used as a hunting-box by Sir Francis Burdett, and situated within a few miles of Melton Mowbray in a sea of grass country; it is typical of Leicestershire. In the same way that Derby day is a public holiday for the Londoner, so the opening meet of the Quorn is regarded as an annual picnic for Leicester and all who live within a wide radius of the scene. For ourselves, each recurring occasion is a milestone in life's journey, that brings a sense of congratulation to find we are still "on the active list." The Leicestershire pastures and fences, sacred to the memory of "Squire" Osbaldeston, Assheton Smith, and many another master, still make the most famous county in England the playground of soldiers, statesmen, and all sorts of people. We claim for hunting that it does more to make English-

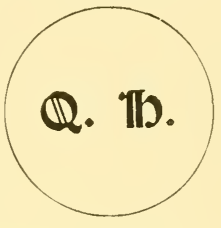

The Quorn Hunt button men what they are, and keep them as they are, than any other branch of sport.

The old cobble-paved streets of Melton resound with the clatter of horses' feet any hunting morning, as they start out with their second horsemen to some distant meet. Time was when the thoroughgoing Meltonians followed later, sitting behind a fast-trotting buggy-horse or on the back of a galloping hack. Now a procession of storm-proofcovered motors rush through the town-the latest accessories to sport-bearing in luxurious ease the leaders of the chase. Perhaps those most to be envied are the followers in pony-carts, having no ambition to compete over a country with the riding division, contented to view the battle from afar without hurrying through the day, feeling all the 
better at the end of it for a fine sight, a pleasant picnic in the open, and a modicum of excitement. "Taking on " a day's hunting in such a way is surely an idealistic form of the " rest cure" !

Melton must be proud of the splendid dignity of her fine church tower, which rises superior to the modern invasion of trade factories and chimneys. Placed in a grass country valley, through which runs the river Wreake, the town appears to be divided in opinion as to whether its prosperity depends on cheese and pork-pie making or fox-hunting. To posterity the fame of the town will be handed down as "the metropolis of fox-hunting," its desirability for a centre of sport being discovered about the beginning of the last century by Mr. Cecil Forester when hunting with the Duke of Rutland's hounds and Mr. Hugo Meynell's. For a long time Melton was a resort for hunting men only, who put up at the hotels and stabled in the town-this probably being the most prosperous period in its history. Since ladies generally took to hunting and graced the field with their presence, palatial hunting-boxes and mansions have sprung up all around the district, out in the country and within easy distance of the four crack packs of the shires.

On a Kirby Gate day the procession from Leicester or Melton more or less resembles a racego-meeting crowd, the carriage company being enormous; every degree of vehicle being represented, from the motor-car to the milk float-the ordinary cart of the country. Then there are the heavily-laden brakes out of the towns, full as they can stick of people who look as if they meant to enjoy themselves, the big hampers up by the coachman promising well. Thousands of spectators on foot turn out to take their stand on the high ground by 
Gartree Hill covert or watch the crowd assemble in the big field by Kirby Gate. The police are there to regulate the traffic at the fixture, the vehicles being pulled up in lines two deep, allowing room for the followers of the hunt to arrive. The whole scene has a holiday-making air about it, a freshness that gives an opening note for the first blush of pink and the commencement of another season's sport.

The preliminaries are the same every year, the

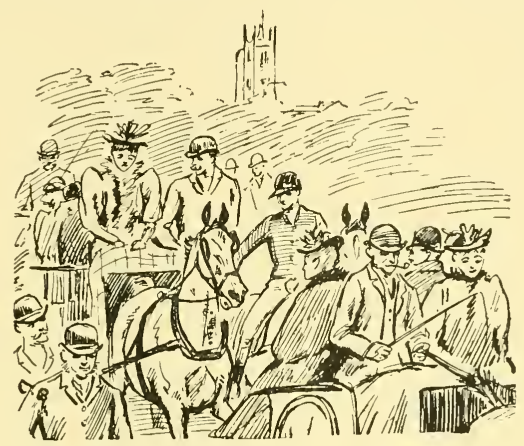

From Melton.

crowd gradually arriving on the vast scene, which is capable of staging them, eager to recognise the features of well-known habitués of the hunt, who season by season flight in like winter migrants from all parts of the world, to make Leicestershire their headquarters for the next five months. It is the most interesting assemblage in the world to watchthoroughly cosmopolitan, representative of all ranks and degrees in every walk of life. As a spectacle it gives a splendid view of types, nationalities, and personalities, whose hard, serviceable countenances prove the vigour and wholesome energy promoted by hunting, its influence being felt in many more 
serious undertakings in life, on which the prosperity of a nation depends.

For many years we went to Kirby Gate to get a sight of Tom Firr, the figure-head of hunting, who personally hated all fuss and show, quietly sitting his horse, the centre of the great assembly, unmoved and apparently unconscious of the admiring crowd. A man of very few words, he had the appearance of a philosopher or an archbishop, and was one whose intellect would have placed him high in any walk of life. Believing that silence is golden, Tom Firr would never allow his hounds to throw their tongue at the feeding-house door, nor did he allow it when unkennelled for hunting, his argument being "that a foxhound should speak only to a fox; his pleasure and affection he must show by his stern." With regard to the breeding of hounds, there is no question that Firr bred more for pace than appearance. Perhaps he was not sufficiently fond of going away from home for blood, as he often said, "So-and-so may stand well and be nice to look at on the flags, but have you seen him hunt a fox? Is he a better foxhound than my own Soand-so ?" Like most huntsmen he had one hound to whom he pinned his faith to see him through in the field or in the kennel, and Tom Firr's particular hound was Alfred ('72), who as a puppy came to Quorn in a basket, and was by Mr. Garth's Painter, out of Affable by the Badminton Forester. Tom Firr used to say he was a model twenty-four-inch foxhound to race over the Leicestershire pastures, and he won first prize with him at the Alexandra Palace Foxhound Show, July I875. In Baily's Magazine of October 1906, Mr. G. S. Lowe says of Quorn Alfred: "Mr. Fernie's Ferryman takes into his pedigree, nearer perhaps than any other, the 
blood of the Quorn Alfred, who was undeniably great. He was, no doubt, very highly bred-a wondrously handsome hound; moreover, his stock were so good in many kennels that the only question is, did he fit a better ancestry than Mr. Garth's Painter out of Affable by the Badminton Forester?-though it was good enough as it stood." Other packs Firr went to for blood were the Belvoir, the Warwickshire, Brocklesby, and Oakley.

Tom Firr, the finished horseman, combined the qualities of nerve, hands, and seat in a remarkable degree. The quietest of riders, jumping fences appeared to be only an immaterial detail of the chase. Never in a hurry, he always seemed to arrive at the right spot in a fence, over

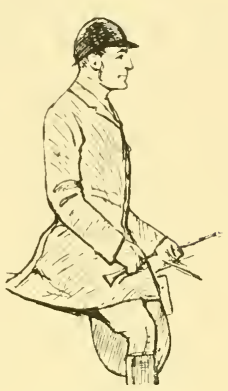

Tom Firr. which he glided without any apparent effort. Riding with a rather longer stirrup leather than is the fashion to-day, he was always in harmony with his horse, and never lost his temper. Such was the man, chosen as a model for the rising generation-" Tom Firr, the pink and pattern of his calling."

Other huntsmen we have seen leading the Quorn battalions on a Kirby Gate day were Walter Kyte, tremendous over a country, and Tom Bishopp, a very smart servant of the chase, whose experience and perfect manners place him in the front rank of his calling. Latterly George Leaf comes on the scene, one of the rising stars, who learnt something of his art when whipper-in under Ben Capell, and the Belvoir huntsman owns to having been influenced by Tom Firr, whom he served under in his early career at Quorn; so that the spirit of the great master of the noble science is still there to 
animate the profession of which he was so famous an exponent.

And now let us imagine ourselves at the meet to-day, under the mastership of Captain Frank Forester, a hound-man of experience, who carried the horn in Ireland when master of the Limerick, and afterwards for the Old Berkshire. Leicestershire born, the master of Quorn has the advantage of being a scion of a family long and honourably connected with fox-hunting in the country, a grandson of Lord Forester, for some time master of the Belvoir, and nephew to Colonel the Hon. Henry Forester, so happily known to old Meltonians as " The Lad," who rode gallantly when past threescore and ten. "Captain Forester rides extremely well-bred horses, most of them in the Stud Book;" so Captain Hughes Onslow, who hunts from Braunston in the Cottesmore country, tells us in an interesting article which appeared in the Badminton Magazine, December Igor. "He likes a somewhat smaller horse than do most people in these parts, and considers $I_{5} .3$ to be the ideal height. Three of his best at the present time are White Legs by Romanof, Tranby by Tranby Croft, winner of the Ladies' Purse at Melton, I907, and Barnetby, a beautiful chestnut horse, full of Stockwell blood, who won the Foxhunters' Chase a couple of years ago. White Legs and Barnety carried the master every Monday and Friday with the Quorn last season, and I greatly doubt if any two other horses in England galloped as many miles or jumped as many fences. Both are high-couraged horses and need a bit of riding."

The post of deputy to the Quorn during the mastership of Lord Lonsdale, and afterwards Captain Burns Hartopp, was often very ably filled by 
the Hon. Lancelot Lowther, hunting from Asfordby Hall, but now migrated to the Cottesmore to fill a similar position in that country. A lifelong experience following the chase has given him an eye for a country and knowledge of the run of a fox, coming at opportune moments of great assistance to the huntsman, who when in difficulties is pretty sure to turn to Mr. Lancelot Lowther.

A study of hunting records convinces one that England would be poorer without its House of Lords, for on the active list is to be found quite an array of Dukes, belted Earls and Barons, many of whom act in the capacity of "common or garden huntsmen." There is hardly one claiming the distinguished title of II.F.H. who would not admit that Leicestershire was the school in which he graduated before taking office with some remote pack, far removed perhaps from the fashionable shires. Such empire-making work has been carried on by members of the House of Lords for generations, long before the presentday crop of nouicaux riches were dreamt of. Fortunes have been spent by titled families for the good of sport and the welfare of the country-side. The history of our titled aristocracy is inseparable from that of fox-hunting, and except for their hereditary sporting instincts and large-hearted generosity, England would not hold the proud position she does to-day. No follower of the chase can subscribe to the "wild-cat theory" that the House of Lords requires either mending or ending.

Distinguishable amongst the crowd at Kirby Gate is the fine presence of Lord Belper, Chairman of the Quorn Hunt Committee. Other very wellknown personages in the world of fox-hunting are Elizabeth Countess of Wilton, and Mr. A. V. Pryor, at whose house, Egerton Lodge, the Quorn hold 
their annual Melton meet, generally the morning after the Hunt Ball. It is easy to find the commanding presence of Mr. Henry Chaplin, ex-Minister for Agriculture, who in the seventies was a brilliant master, hunting his own pack at Blankney, and one of the best of the heavy-weight division. Once again on the scene, we recognise Mrs. Asquith, wife of the Prime Minister, who when Miss Margot Tennant witched Leicestershire with her finished style riding to hounds. Two fine horsemen are Mr. Arthur Coventry, Starter to the Jockey Club, and Mr. J. Maunsell Richardson, of Grand National fame, who still rides at the top of the hunt with the gaiety of five-and-thirty, a model of seat and hands for the rising generation. There also are Colonel the Hon. W. Lawson, who goes extremely well in point-to-point races, the Duke of Marlborough on a grey, and the Duchess of Newcastle in green. Those whom now we miss are Mr. Beaumont Lubbock, the best-looking of men; Captain Tom Boyce, Melton's favourite, who used to hang the best boot with the Quorn; Mr. Cecil Chaplin, one of the quickest of the heavy-weights.

The Kirby Gate gathering of 1908 gives a representative group of regular Leicestershire hunting folk, the Master to begin with, Mrs. Frank Forester, driving, Miss Mary Forester, the Duchess of Newcastle, Elizabeth Countess of Wilton, Mr. A. V. Pryor, Earl Compton, Lady Lillian Grenfell, Lady Violet Brassey, Lady Augusta Fane, Lord Hamilton of Dalzell, Lady Cowley, Major Sir John and Lady Milbanke, Sir Keith Frazer, the Hon. Mrs. John Gretton, the Hon. R. and Mrs. Wyndham, the Hon. Charles Fitzwilliam, Colonel W. A. Peake, Major Bradford Atkinson, Captain and Mrs. R. B. Sheriffe, Captain Burns Hartopp, the Miss Burns 
Hartopps, Major and Mrs. Mann Thompson, Mr. and Mrs. C. J. Phillips, Mrs. Alfred Brocklehurst, Mr. and Mrs. C. Cradock, Colonel the Hon. and Mrs. W. Lawson, Mr. and Mrs. R. E. Strawbridge, Master Strawbridge, Mr. A. S. Cochran, Miss Muir, Captain Johnson, Major Wilfred Ricardo, Major Heycock, Captain and Mrs. Archibald Smith, Captain and Mrs. David Beatty, Captain Vickerman, Major and Hon. Mrs. Tennant, Mr. Vere Chaplin, Captain Herbert Wilson, Captain and Mrs. J. F. Laycock, Mr. A. L. and Miss Duncan, Captain and Mrs. N. St. Clair Allfrey, Mr. and Mrs. A. E. Burnaby, Miss Burnaby, Miss Mary Hartopp, Mr. Bernard Wilson, Mr. Algernon and Miss Turner, Captain H. Ashton, Captain Brown, Mr. Angus Mackintosh, Mr. Fielden, Major J. H. Martin, Mr. J. F. and Miss Cartmell, Mr. and Mrs. C. E. Hay, Mr. V. R. Pochin, Mr. and Mrs. H. G. Fenwick, Mr. J. O. Paget, Mr. O. F. Mosley, Mr. J. T. Wade, Mr. W. Panye, Mr. W. Gale, Rev. P. F. and Miss Gorst, the Rev. R. C. Dashwood, the Rev. J. P. Seabrooke, Dr. Hugh Roberts, Mr. "Danny" Maher, a new butcher in blue, Harry, the runner, and all sorts of people-a list so short of the reality as to need apology.

The Earl of Lonsdale's Mastership of the Quorn from $I 893$ to 1898 will always be remembered for its brilliancy and high average of sport, Melton being full of talent and fashion. Such a combination as Lord Lonsdale and Tom Firr is seldom met in a lifetime; the brilliance of both in the field comes in for mention by Major G. J. Whyte-Melville in his "Riding Recollections." Mr. J. Otho Paget, in his interesting book on "Hunting," one of the Haddon Hall Series, is another who says, "The three best all-round horsemen that I have seen are Lord Lonsdale, Mr. Cecil Chaplin, and Tom Firr. 
All three have different styles of riding, but besides their horsemanship they all have the knack of getting the shortest way to hounds." When Firr was incapacitated through accident, Lord Lonsdale hunted the Quorn hounds, and did it to the entire satisfaction of a very critical field.

The opening meet at Kirby Gate in I903, which inaugurated Lord Lonsdale's mastership, was a scene of exceptional splendour, attracting a crowd of record dimensions. Tom Firr, who commenced his twenty-third season, appeared wearing a "pink" coat, leathers, chain, whistle, battle-axe and swannecked spurs, astride a bang-tailed chestnut horse with no mane. He looked more solemn than ever, even when greeted by his contemporary Frank Gillard from Belvoir, riding a short-tailed black horse, Smoker, renewing memories of the seventies, when he was huntsman to the Quorn. The whole of the Quorn staff were mounted on bang-tailed thoroughbred chestnut horses; the two whippers-in being Alfred Earp and Tom Parker; the pack for the day, twenty couple of the bitches. Every up-to-date detail and possible improvement to ensure sport had been thought out by Lord Lonsdale, whose ideas are always in front of his time. The hunt second horsemen were provided with leather cases, containing old brandy and every appliance necessary in the emergency of accident to man or horse. It was said that a small yellow van which followed, to pick up lame hounds, also carried changes of raiment and food for the men.

The commissariat department for a hunting staff is a point that often wants more consideration, and might save us from a dyspeptic race of huntsmen. The weakest spot in the anatomy of a hunt-servant or horse is the digestion, for long hours and improper 
feeding are bound to bring about troubles in later years. Ideas have altered since the days of Anthony Trollope, when Spartan fare was considered sufficient out hunting, washed down by a concoction of "vinegar and water." A good lunch and a second horse at one o'clock are not the worst part of twentieth-century hunting! Tom Firr, one of the most

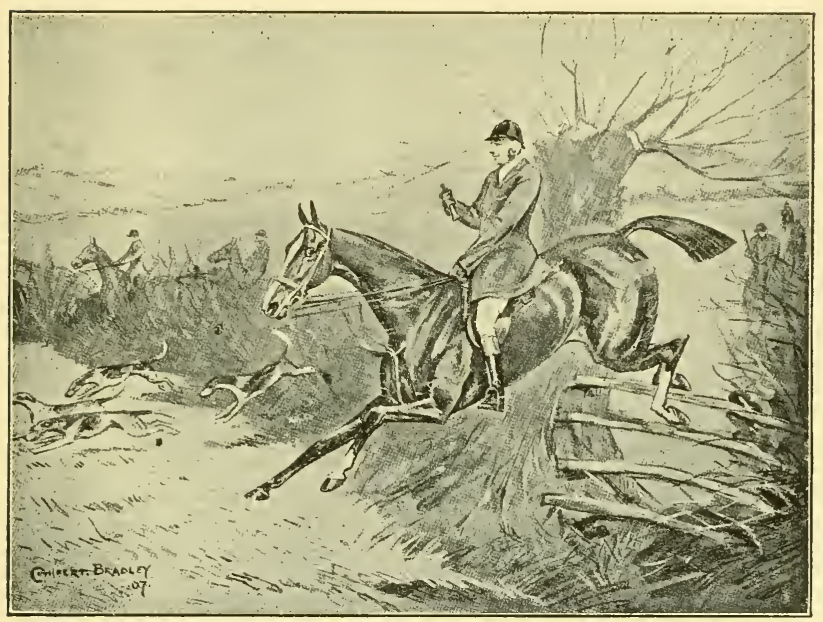

The Earl of Lonsdale.

abstemious, preferred claret to anything else; and Frank Gillard was another who went for the same wine or tea, the late Sir Thomas Whichcote sending the Belvoir huntsmen many a dozen of claret. For over a quarter of a century these two famous huntsmen rode with unimpaired nerve in front of Leicestershire fields, which every season are reinforced with young blood full of ride!

An account of Kirby Gate day without a list of some who were there would be incomplete, so just an example: "The Lad"-Colonel the Hon. 
H. H. Forester, the oldest Meltonian; the Hon. Lancelot Lowther, doing field-master work ; the Hon. Mrs. Lancelot Lowther, riding the well-known grey "The Rake"; Miss Sybil Lowther, Captain Tom Boyce, the Countess of Cardigan and Lancastre, author of a book of lively reminiscences, Elizabeth Countess of Wilton, Mr. Beaumont Lubbock, Mr. and Mrs. Cecil Chaplin, the Marquis of Cholmondeley. Past and present masters of hounds included Lord Chesham, Lord Manners, Captain Warner, Captain Peacock, Mr. Tailby, Mr. Fernie, Captain Pennell Elmhirst, and Sir Bache Cunard.

Future masters of hounds were represented by Lord Annaly, Captain Burns Hartopp, Mr. Charles

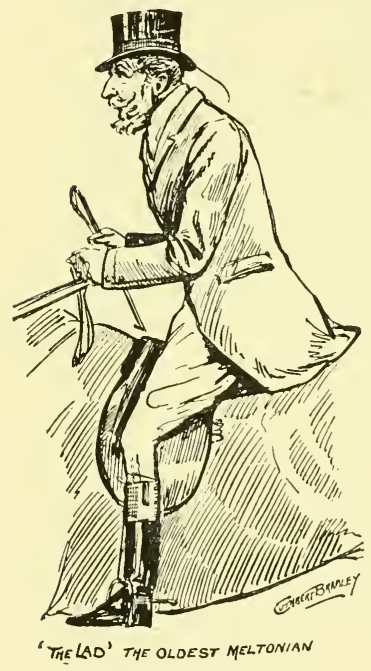

Colonel H. H. Forester.

McNeill, Lord Huntingdon, and Lord Charles Bentinck - a galaxy of talent to help to make a record show in the annals of foxhunting. Mr. Henry Custance was there to represent racing, and a piebald horse named " Joseph's Coat," that jumped the very best, ridden by Captain King King, left a lasting impression as he flitted across country with a comet-like tail.

Pleasant memories must always be associated on this occasion with Mr. and Mrs. James Hornsby, hunting from Stapleford Park, one of the most beautiful old-world Leicestershire hunting-boxes, where we stayed, to ride a good roan horse, Remus-a reliable mount in a crowd. At this time Mr. and Mrs. James Hornsby were regular followers of all 
three Leicestershire packs, and the Cottesmore meet at Stapleford was the occasion for a magnificent breakfast.

Contrary to custom, Lord Lonsdale did not go first to Gartree Hill, owing to a death in the ramily of the owner of the covert, but moved the procession, which extended over a mile long, across to Welby osier-beds. A field away from covert we were held up by the deputy-master, Mr. Lancelot Lowther, riding a short-tailed black horse, the crowd probably numbering over three hundred horsemen. The wait was only a short

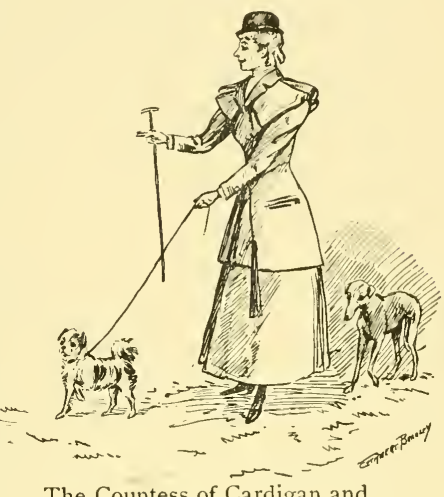

The Countess of Cardigan and Lancastre. one, when the silver whistle of the whipper-in was heard ringing out, announcing that a fox had been viewed afoot. Lord Lonsdale is of the same opinion as the Duke of Beaufort and Colonel $\mathrm{J}$. Anstruther Thomson, that the sound of the whistle has less chance of heading a fox back to covert than the voice. Two twangs from Firr's horn and the flag dropped to a good start, the large crowd sweeping down the hill-side like an avalanche. As Mr. H. Cumberland Bentley says in his Quorn hunting song, dedicated to the Earl of Lonsdale:-

"Then with a rush like a stemmed torrent bursting

Restraint, they are riding, three hundred and more, For a start, and their hoof-strokes, the velvet turf shaking, Beat like the sound of the surf on the shore."

Streaking away up the plough with a line for Grimstone Gorse, through which covert we rode, 
there was a perfect whirlwind of galloping horses, the very first fence emptying numerous saddles, for the country was blind and seats were loose. Sunshine and cold wind rendered scent catchy, but at last hounds marked to ground in a main earth, a move then being made to Lord Aylesford's Plantation for a fresh fox. This time the chase swept on by Shobey Scholes, back again to Grimstone Gorse, a serious fall happening to one of the ladies when jumping under a tree. Lord Lonsdale, who seemed

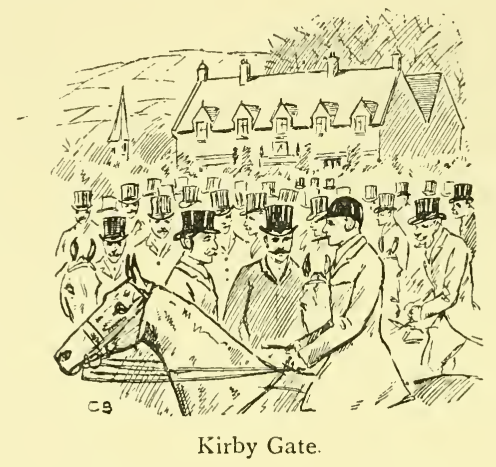

to be ubiquitous all day marshalling his forces, was first off his horse to render assistance, and with the help of a doctor and a hard-riding vet. from Grantham, who filled his cap with water, everything possible was expeditiously done.

Meanwhile, the chase swept on, finally marking to ground in a shallow drain between Old Dalby Wood and Six Hills, by which time there were numerous dirty coats and concertina'd hats.

Lord Lonsdale dismounted to survey the position, while Firr drew hounds away, and the first whipper-in found the mouth of the drain. At the right moment Harry, the runner, appeared on the 
scene leading a brace of wire-haired terriers, and strapped on his back was a Lonsdale patent pick and spade with which he went promptly to work, cutting down into the drain. The whipper-in, with the help of a terrier, was able to draw the fox by his brush, and wriggling at arm's-length flung him away. For a field he led them, and then the leading hound shot out and scored the first kill of the season. Once again we summon Mr. H. Cumberland Bentley to our aid :-

"Their 'hackles' are up, they are running to kill,

Till Firr's loud 'Whoo-whoop,' ringing out from the hollow, Awakens the echoes of valley and hill."

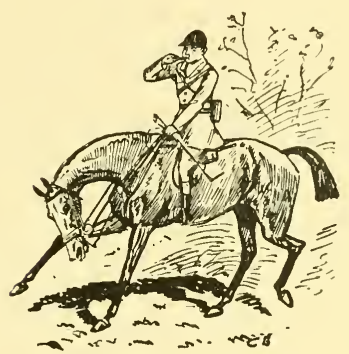

The Silver Whistle. 


\section{CHAPTER III}

WITH FRANK GILLARD ON A LENTON BROOK DAY. FORTY MINUTES AND A KILL

The influence of a good day's sport-The Folkingham fixture revivedLord Edward Manners-The field out with the Belvoir-The Folkingham country-Harry Maiden-The morning hunt from Heathcote's new covert-Again from Folkingham little gorseA cracker from Sapperton Wood-The line of grass by LentonLenton Brook-What Will Goodall said about it-Mr. F. A. Soames leads the way-Mr. Edgar Lubbock's record at the brook - Lord Willoughby de Eresby-The Hon. Claude Willoughby de Eresby-Mr. T. A. Rudkin and his medicine bottles-The kill by Ingoldsby-Those up at the kill, and presentation of the brush, mask, and pads-Back to kennels in the dark-Gillard's untirable enthusiasm-A fox-hunting sermon from the Folkingham vicar.

"You gallantly hit off your fox, And over those Sapperton fields, Full many were in the wrong box.

My ardour exceeded all bounds.

At Haceby I counted but six ;

So to keep him alongside the hounds,

I treated my nag to some kicks.

No! Walcot bold Reynard refuses, And Folkingham gorse he disdains ;

The Aswarby coverts he chooses-

Look out for the Aswarby drains!"

- Lays of the Belvoir Hunt.

THERE is no doubt about the joy of a good day's sport, for its memory can cheer the heart and keep us warm many a long year afterwards. The beautiful Belvoir have put many a fine performance to their credit, but the events of Friday, November 23, I894, will never be forgotten by those who were lucky enough to participate in the stirring afternoon gallop of forty minutes from Sapperton Wood 


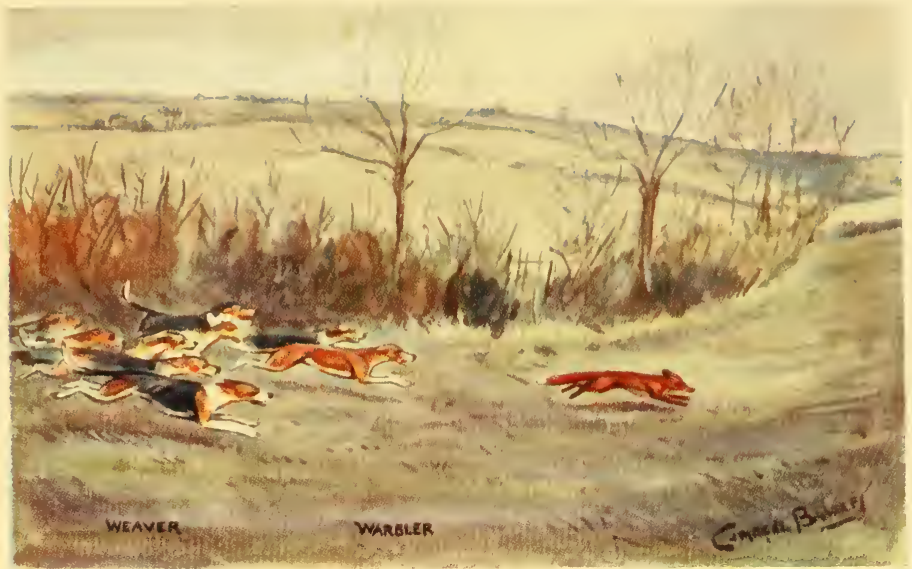

A FLYING START FROM FOLKINGHAM LITTLE-GORSE

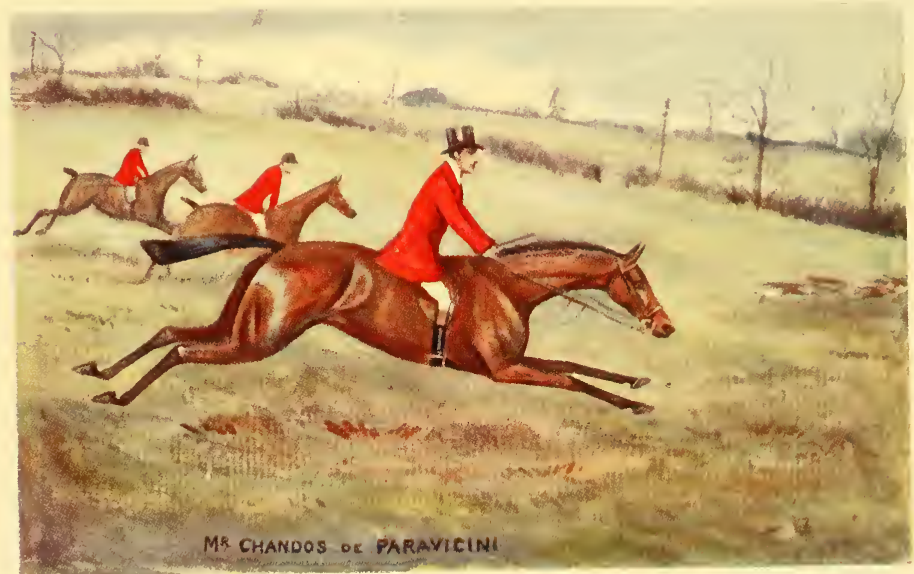



to Ingoldsby village, where hounds killed their fox. Red-letter days come few and far between in any one's life, and he who desires to know what pleasure will really give him should not expect to taste delights too frequently.

Sport this season had been above the average, scent lying well after abundant rain, which washed and settled the ground; so there was a keenness amongst followers enjoying a sequence of

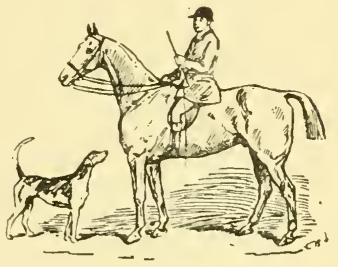

Frank Gillard. good days. The meet was in the market square of Folkingham, an old-fashioned, red brick town of six hundred inhabitants, placed on the coach-road midway between Lincoln and Peterborough, about twenty-five miles distant from each. It was a happy idea on the part of the sixth Duke of Rut-

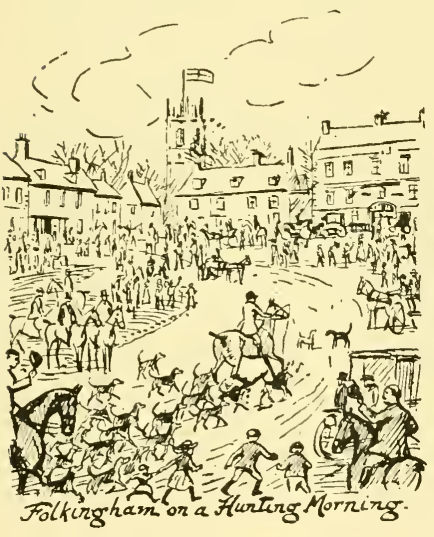
land and his huntsman, Frank Gillard, to revive this fixture, which had not been held for fifty years, dating back to the time when "Gentleman" Shaw was huntsman at Belvoir, and Sir Gilbert Heathcote, lord of the manor of Folkingham, won the Derby in I838 with Amato. The event also celebrated the homecoming of the present squire, Mr. Thomas A. R. Heathcote and his bride, the meet being opposite their house, where a large field assembled.

Glancing at the list of names comprising the field 
shows how quickly the following of a hunt comes and goes, the gaps in the ranks being replaced by new faces. Amongst the gay throng on the scene, November 23, I894, was the late Lord Edward Manners, the Duke of Rutland's second son, who so successfully undertook the duties of field-master to the Belvoir during Gillard's last few seasons as huntsman. Although handicapped by wearing glasses, he was a fearless rider and owned some nice horses, his best perhaps being the long-tailed chestnut, Oakport, winner of one or two chases with his owner in the saddle.

Those out included Mr. Thomas A. R. Heathcote, Mr. Frank and the five sisters, Miss Lucy, Gertrude, Maud, Emily, and Victoria Heathcote; Lord Willoughby de Eresby (returned M.P. for Horncastle again IgIo election); the Hon. Claud Willoughby de Eresby, elected M.P. for Stamford, General Election I9Io; Sir George and Miss Whichcote, Major W. Longstaffe, Mr. and Mrs. Edgar Lubbock, Major and Mrs. F. Amcotts, Mrs. E. Royds, Mr. Arthur and Miss L. Willson, Captain J. Rennie, Mr. F. and Miss G. Parker, Mr. C. R. Hodgson and Miss K. Hodgson, Mr. Vincent Hemery, Mons. Roy, Mons. Coutourie, Count Jantel, Colonel Theobald, Colonel A. de Burton, Mr. F. A. Soames, Mr. F. Worsley, Major Charles Thorold, Mr. J. Hutchinson, Mr. T. Robarts, Mr. A. and F. Schwind, Mr. H. Smith, Mr. H. M. Escritt, Mr. J. and J. E. Grummit, Mr. J. Hoyes, Mr. J. Rudkin, Mr. C. Rudkin, Mr. A. Pick, Mr. J. Ward, Mr. T. Casswell, Mr. J. E. Casswell, Mr. T. Rudkin, Mr. A. Rudkin, Mr. A. Shepperdson, Mr. W. Baily, Mr. J. Constable, and many more to swell the field into a hundred and fifty horsemen, besides the contingent driving, which included Mrs. Thomas A. R. Heathcote. 
Very picturesque was the scene of the hunt wending its way down the wide coaching-road on which the town is built, to visit Heathcote's new covert, a mile distant-a fox-ground planted by the squire's father, the Rev. T. Heathcote, for many

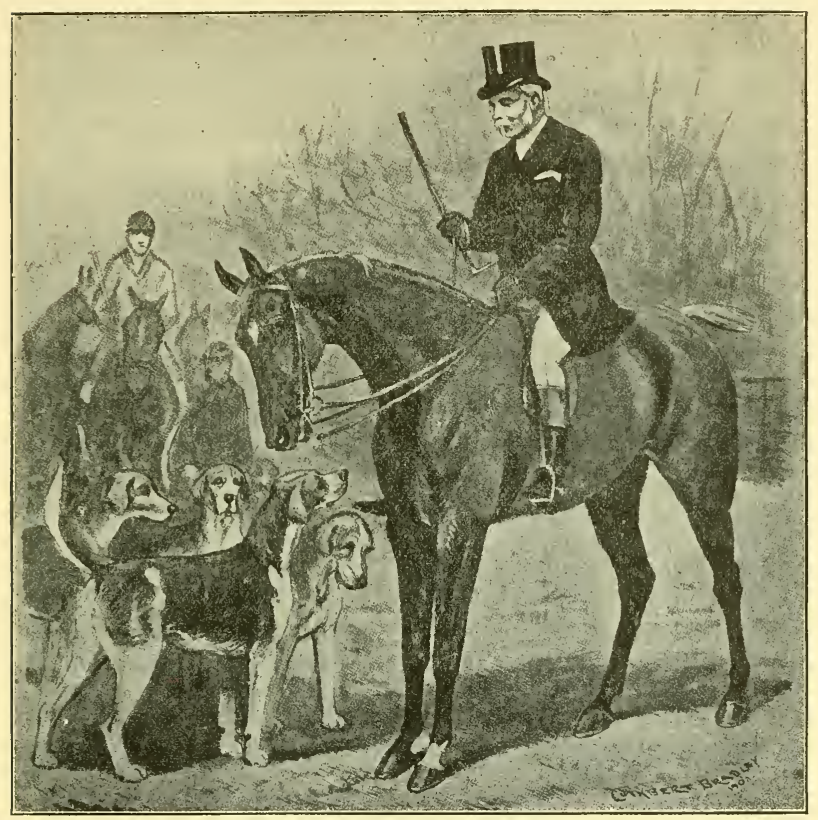

Major W. Longstaffe on Silver Tail.

years Vicar of Lenton. Situated in a good wheatgrowing and grazing country, the fences are strong and the ditches dug deep, so that a safe jumper is a sine qua non when hounds start a travelling fox in the district. At this period of history Gillard and his staff were not well mounted, but it was surprising what they were able to accomplish, though falls were frequent. In the first place, 
Folkingham is a good twenty miles from Belvoir, and the same distance had to be covered at the end of the day when the horses returned to kennels. The wear and tear was necessarily considerable, and the hours very long for man and horse-a twelvehour day from stables being of frequent occurrence.

The first whipper-in was Harry Maiden, a determined rider who took twenty-five falls in the first half of his last season, and then came up smiling at the finish to hunt hounds when Gillard was incapacitated by an accident. Afterwards Maiden went huntsman to the Chiddingfold and later to Sir Watkin Williams-Wynn. The last news we had of cheery Harry Maiden was in a shipwreck during October 1908, when with fourteen and a half couple of hounds he set sail for Egypt to take up the appointment of huntsman to Prince Kamel Pasha. The liner in which he was sailing, named the City of Dundee, collided with another vessel in a fog, and sank within seven minutes in Cardigan Bay. All the passengers and most of the crew were saved, but the hounds, sad to relate, went down with the ship.

It was a typical Belvoir day, spent in steady hunting during the morning, ending with a blazer in the afternoon-the time of day these hounds are so often seen at their best, running on with untirable courage. Getting away with a fox from Heathcote's covert they ran from the low side, with a point for Pickworth village, the musical halloa from Bob Knott, who for so many years rode second horseman to Gillard, setting the hunt galloping down the grass field by the side of covert, and the first fence away, a blind place with an up-hill take-off, put three good men down. The first to fall was Mr. Vincent Hemery, riding a steeplechase mare 
Frailty ; another was the veteran Mr. Tom Casswell, a fine horseman, who learnt the art in the Southwold country, the blind take-off trapping his old chestnut horse Alabaster; and Mr. Austin Pick, schooling a four-year-old, also fell, none of the trio being any the

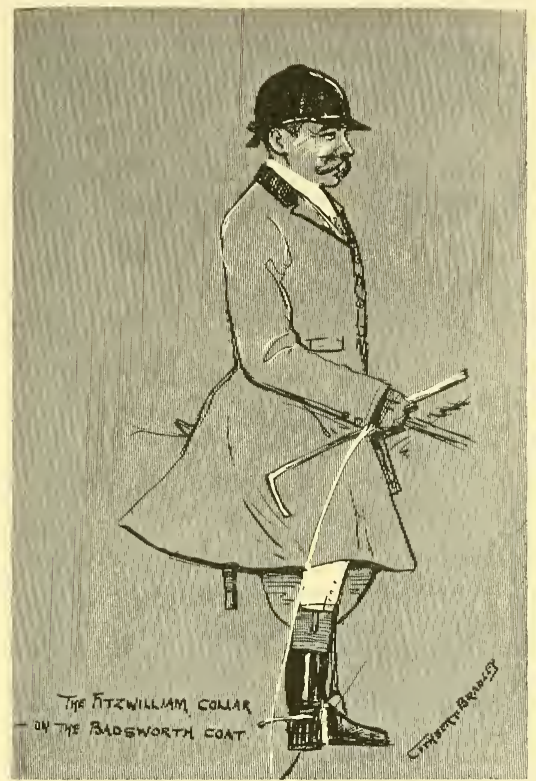

Mr. C. B. E. Wright, M.F.H.

worse. All the way there were plenty of rough fences to jump, Frank Gillard and Lord Edward Manners being in their accustomed place "at the top"; a steady hunting run of nearly an hour ending between Walcott and Threekingham, where hounds had to acknowledge themselves beaten on cold-scenting plough-land.

A return for a fresh start was then made to 
Folkingham Little Gorse, a good four-acre covert belonging to Mr. Thomas A. R. Heathcote. Without throwing hounds in, Gillard sounded the notice to quit on his horn, moving a fox, which was signalled away by Bob Knott on the low side. Hitting off the line, they rattled merrily along towards Birthorpe,

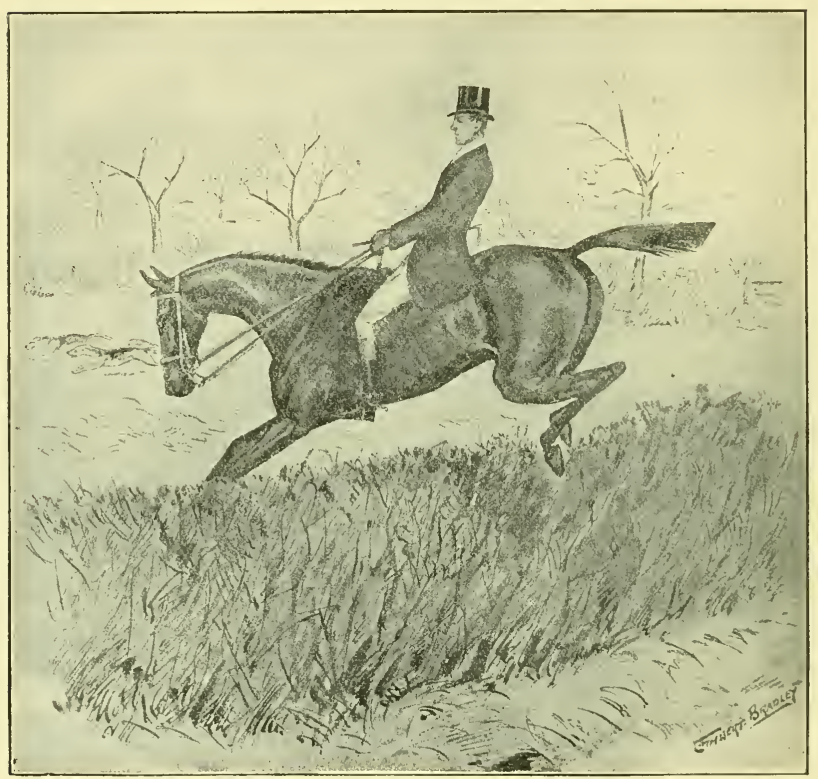

Mr. Joshua Fielden, Ex-M.F.H.

turning up to Stow, losing all trace on the plough country by Threekingham, after going for fifteen minutes. An uninteresting period then resulted whilst searching for a fresh fox in a journey by Spanby, Newton, and Haceby, many of the field turning homewards.

As the mists of a short November afternoon were closing in, Gillard threw hounds into Sapperton 
Wood-true to the old Belvoir tradition to keep drawing so long as daylight lasted, no matter what the distance back to kennels might be. Immediately there was an opening note, followed by a joyous chorus as they all came together, the music setting every one's blood tingling with pleasure, so that our field master had to "hold us up" by the gate.

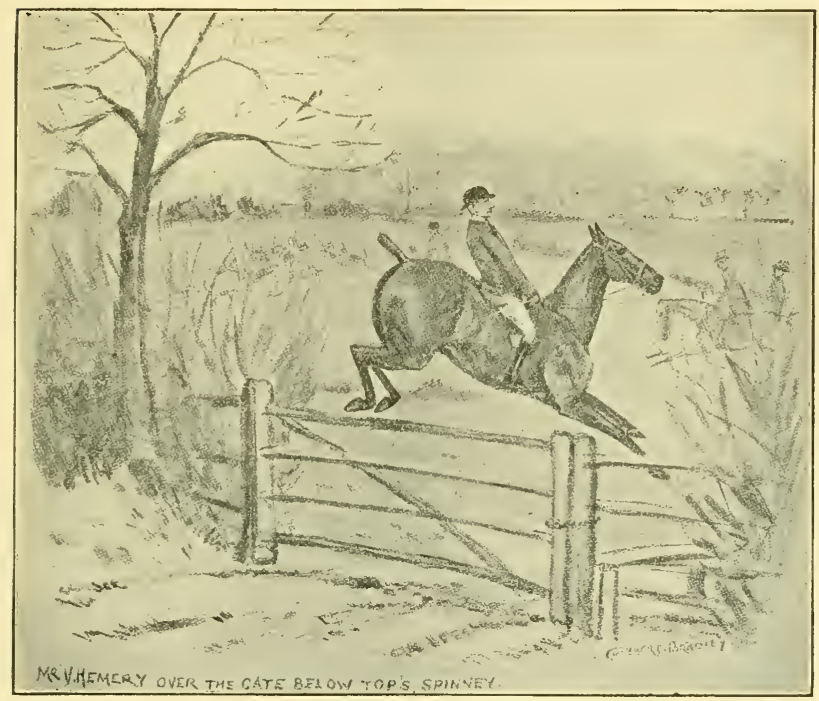

Mr. Vincent Hemery.

A few minutes of suspense followed, and then they had him away on the right side for Pickworth Wood, through which he shot like an arrow, sending the pigeons rocketing from their perches. The air was keen, scent rising, and there was not one amongst us who did not realise that a good hunt was impending. As we hurried through the gate on to the Pickworth Road, summoned by the frantic yells of a tall figure in a long dark overcoat, running 
bareheaded, waving his hat in the direction of Lenton, we recognised Cox of Ropsley, one of the keenest of the foot division. He had viewed the fox away, a straight-necked one with white-tagged brush, and shouted, "They'll run like hell's devils to-night ; you mark my word if they don't." It was the rare instance of a true prophet, for run they did, squandering the following all over the country!

From Sapperton Wood, stretching away southward, is a bit of arable country across to Hanby, with blind fences full of white grass, and those who jumped quickest out of the road and were able to keep their place had the best of that blazing forty minutes' gallop, for hounds never checked. Turning right-handed by Mr. James Rudkin's house at Hanby, they embarked on a line of beautiful grass country, dipping into the valley of the Lenton Brook, the journey being pasture land all the way to Ingoldsby Wood, seen in the blue distance. Several riders fell before the grass was reached, trapped by the blind fences-Lord Edward Manners, Sir George Whichcote, Major Charles Thorold, Mr. A. Schwind, and Mr. F. H. Schwind being amongst the number who extinguished their chance of seeing the finish.

Down the grass slope hounds fairly raced, splashing over the far-famed Lenton Brook, with its steep banks and twenty-five feet of open water, no matter where you have it! We are not therefore surprised to hear that a former huntsman, Will Goodall, always said, after jumping Lenton Brook, "he had accomplished a good day's work." Mr. F. A. Soames, on a chestnut horse, Kedar, was to be seen cramming his hat on, and his spurs in, riding down to the classic stream, glorying in the chance of having a fling at it, for no matter what he was on, they all 
had to go where hounds went. Brilliant hunter as Kedar, the son of Ishmael, undoubtedly was, he had come along at a good fair pace in holding going, and he could only get the right side of the brook with a fall; horse and rider, however, being quickly up and going again, before those following on could rob them of the lead. Mr. Edgar Lubbock, riding a bang-tailed bay horse, was another who met

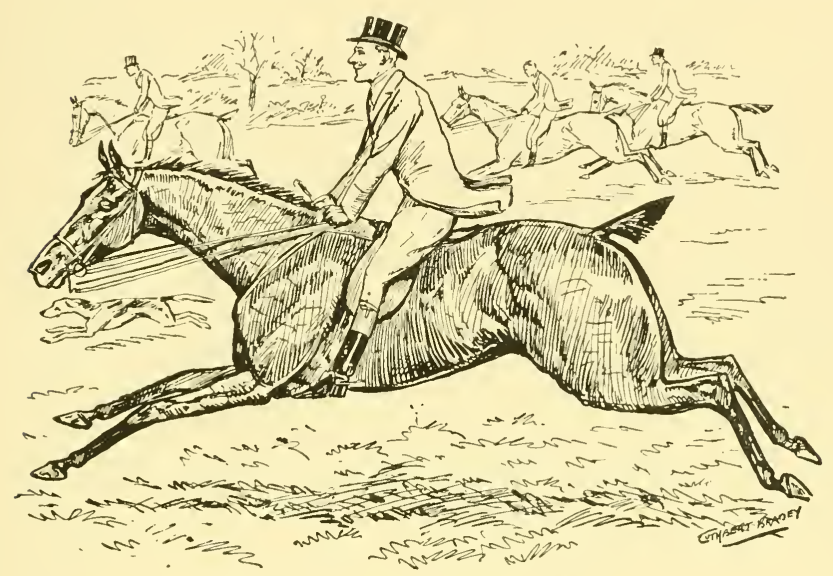

Lord Willoughby de Eresby, M.P.

the formidable obstacle with a smile on his face; and the last season he hunted with the Belvoir held the record for having jumped the Lenton Brook oftener than any other man living. Lord Willoughby de Eresby, riding a dark brown horse with a white face, and his brother on a grey, were both successful in getting the right side, with the select few in the same field with hounds. Soon the mud of the brook was being stirred up by the horses who halved it, including the mount of the second whipper-in, Fred South, which was "clean done." A 
plucky attempt to jump the brook was made by Mr. T. A. Rudkin, the sporting vet. from Grantham, who nicked in the run when on his rounds, and had a bag of blister and lotion bottles attached to the saddle. He too only got the right side with a fall, and the bottles were broken, but he finished the run with the glass clattering in the leather bag.

The majority of us found an easier way round with the hunt staff, for horses at the end of a hard

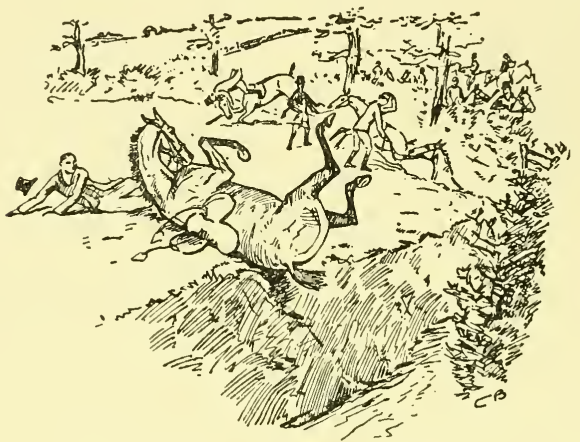

Mr. F. A. Soames down at Lenton Brook.

day wanted nursing, and all of us have not spare necks in our pockets when we go hunting! Say what you will, the man who has a fling at Lenton Brook chances his horse, for the stream is deep enough to break a back if jumped short, and latterly a bridge placed below Hanby has robbed this beautiful line of interest. Harry Maiden managed to make a short cut and get within distance of the lucky half-dozen in attendance on hounds; and by the time the rest of us galloped through Ingoldsby village in hot pursuit, his triumphant "whoowhoop!" was heard near to Mr. Richard Stock- 
dale's stackyard, not half a mile from Ingoldsby Wood. It was a great gallop, and the time was forty minutes from find to finish.

To Lord Willoughby de Eresby the brush was presented by Gillard; Miss Lucy Heathcote, now Mrs. Cuthbert Bradley, securing a pad of this good fox, after enjoying the best of the run up to Lenton Brook, riding the bay mare Guinea-pig. A

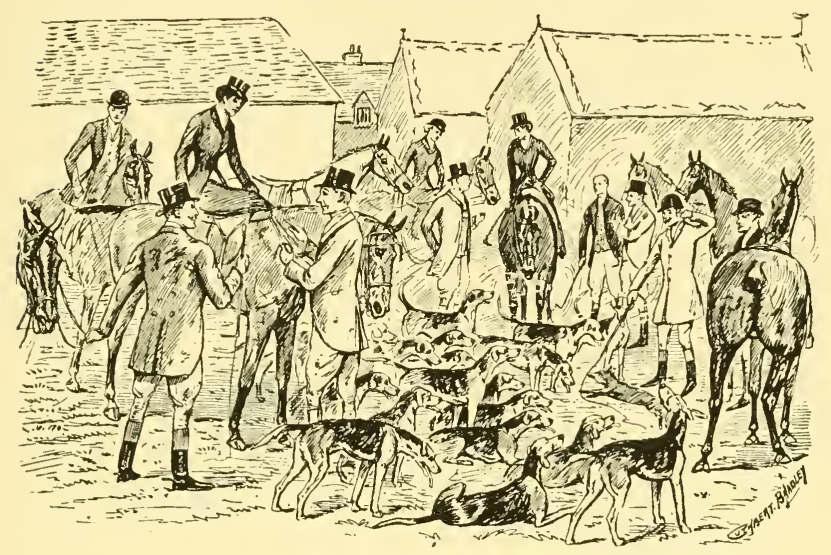

The Kill at Ingoldsby.

pad also went to Miss Emily Heathcote, now Mrs. George Schwind, well carried by a bay horse, Parson, who on another occasion jumped the brook, getting the right side with a scramble on landing. The mask was presented to Mr. T. A. Rudkin, one of the hardest men to hounds on his day, and he was in no way disconcerted at having damaged his veterinary outfit at the brook. Few enjoyed the hunt more than Mr. Lubbock did, always the first to take the opportunity to jump a fence, and one who never owned to a dull day's hunting! During the latter part of the run Mr. Claude 
Willoughby de Eresby lost his hat when jumping stiff timber, and turned up at the finish bareheaded.

It was in the gloaming when Gillard, with hounds and his staff, turned for Belvoir kennels, nearly seventeen miles away. The roads were stony and the night was dark, so lanterns were borrowed from the first homestead, and tied to the stirrup-irons, for fear hounds might be run into by vehicles travelling after dark. Those were indeed heroic times, and well might it have been said that any one day's work from Belvoir was equal to two seen in the provinces! It was no uncommon occurrence to meet the pack coming into Grantham on a dark night, Gillard's horn ringing out a warning when the sound of approaching wheels was heard. How cheery was the greeting as you hailed him in the night! " Had a capital day's sport and killed our fox. You ought to have been with us, sir!" Such untirable enthusiasm was an inspiration, and there were many who never cared to hunt again when Gillard laid down his horn. It was no unusual occurrence for the huntsman to sit down to his wellearned meal at nine o'clock, after a long day spent in the saddle on the distant Lincolnshire side of the country.

The story of the day does not end here, for the Vicar of Folkingham, the Rev. T. A. Stoodley, who realised that his flock, after the events of the stirring day's sport, had been talking and thinking of nothing else but fox-hunting since the Friday, was ready for them on Sunday. Choosing for his text "Evil shall hunt the wicked," he riveted the attention of his sport-loving congregation from start to finish, delivering a most telling sermon; boldly describing what we might fairly suppose are 
the feelings of a hunted fox, when he discovers that efforts to out-pace the pack fail, because he carries with him "something" which proves his own destruction. This mysterious taint, a scent, the preacher cleverly applied to the lusts and vanities of the world, which sooner or later bring the hounds of hell on the track. Vice is their huntsman lashing on the hounds, Remorse and Despair being compared to terriers that follow below ground to bolt the impenitent. Penitence can stop the scent, and put the hounds of darkness off the track, so saving the poor, hunted soul. With penitence put between them and their past sins they are safe, for after all it is only unforgiven sins that leave a trail behind them. The moral of the sermon was, " Repent, or else evil will surely hunt the wicked to destroy him."

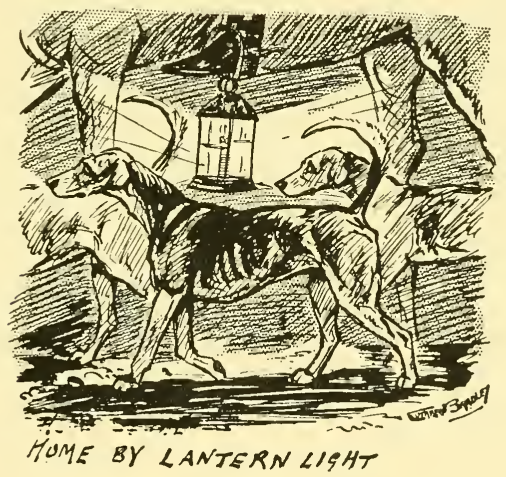




\section{CHAPTER IV}

\section{TWO GOOD DAYS IN 1889 SEEN WITH THE COTTESMORE AND GEORGE GILLSON}

The Cottesmore in the neutral Belvoir coverts-March foxes-The meet at Corby, fifteen miles from everywhere-Mr. WV. Baird and George Gillson-Mr. Baird's hunt horses-The big grey horse in the presentation picture-George Gillson as a huntsman-Gillson's rustic admirers-Some of the field in a good hunt from Corby pastures, and incidents of the run-Away by Lenton Spire-The Rev. Thomas Heathcote-The Rev. Edward Bradley-Cuthbert Bede-The finish at Sapperton-A repetition of the Corby run - The field out-A good start-Baldwin, the flying fox-A good riding field over the steeplechase course by Lenton-The finish by Osbournby hill-top covert-Twenty-five miles back to kennels.

"Now full murk lie the meads upon Barleythorpe plain, And the storm-god is drenching fair Catmos with rain; The mavis and merle they sit silent in bower, And the chorus of the woodlands all tunelessly cower. But at ten o' the morn comes Gillson and horn, Working wondrous change in the scene forlorn. The cry, 'Oh, the hunt's up!' right cheerily sounds, And all Cottesmore's astir with the Barleythorpe hounds."

-Tom Markland in Fores Magazine.

IT seems a long way casting back twenty years to describe two days' sport enjoyed with the Cottesmore, but there are several riding to-day who remember the circumstances as clearly as if they happened yesterday. Until referring to the diary to find the dates were March and April 1889, it was impossible to imagine it was so long ago, but after all a man is only as old as he feels! At the end of the season it has always been a custom with the Cottesmore to hunt the neutral coverts on the borders of the Belvoir country, and, if possible, kill off a few dog-foxes. Though March is a ticklish 
month for scent, yet foxes are on the travel, and should hounds hit off the line of one of these gay Lotharios, the chances are they score a quick, straight run, for blow which way the wind may, a dogfox at this season of the year will travel back to his own ground. On the Lincolnshire border of the Cottesmore country there is a chain of coverts lying between Colsterworth

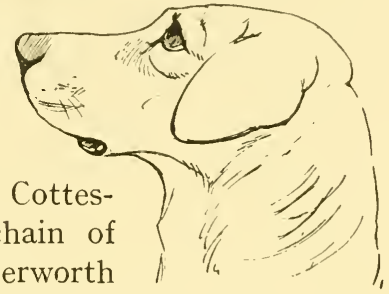
and Bourne, which are neutral for this pack and the Belvoir. It is ground associated with good sport seen in the past, situated in an unpopulated, low-farmed district, a capital country to visit at the end of the season, when more forward arable lands are closed to sport on the score of damage to crops. Essentially a woodland day, for there are vast tracts of forest lying between Colsterworth and Bourne, it is none the less enjoyable and always associated with good hound work. By the older school of sportsmen, who preferred hunting to steeplechasing, these districts were in high favour with a pack like the Cottesmore. Quick, determined, and persevering, there is plenty of scope to show the worth of their breeding when unravelling the line of a stout woodland fox.

The fixture is on the cross-roads known as Corby Birkholme, a point about fifteen miles distant from either Oakham, Grantham, Stamford, or Bourne. Some one who found himself there, and had the locality fully described, went so far as to ask "if the spot was in England ?" Borderland describes it best, but there used to be an old gentleman living at the house on the cross-roads, by name Mr. Wilkinson, ready with a hearty welcome 
for every one and a nip of excellent cherry brandy, making us all eagerness to find a fox as quickly as possible, before the effects worked off. Of course, there is never a crowded field out, but a representative one from both hunts, just the right element to put a huntsman on his mettle to show sport, for those who come these long distances have a business-like air about them! One never quite knows whom we may meet, for on these rare occasions friends from a distance turn up, like ships passing at sea, to hail us on life's journey, and perhaps vanish again into the space of a year or more. What we all perhaps like about a Corby gathering is its provincial character; and the chances are for these woodland hunts Leicestershire clothes and manners are left behind, being out of place. The farmer division is a strong one-good, honestlooking sons of the soil on "nags" innocent of polish; not the horse-dealer fraternity, who prefer a day on the grass with the crowd. The whole district seems endued with the right fox-hunting spirit - a rare tonic for any of us-and the only question of tenant right would appear to be the right of the tenant to ride over his landlord, or of the landlord to take the same liberty with his tenant.

During the mastership of Mr. William Baird, who came from the north and was in office from I880 to I900, great attention was paid to the breeding of the Cottesmore hounds, the kennel being considerably improved by the purchase of drafts from Belvoir in the eighties. For some years William Neal was huntsman to Mr. Baird, but was succeeded in I 888 by George Gillson, who held the post until the change of mastership in I9oo, when he retired. George Gillson was well known in Leicestershire, having been first whipper-in at Quorn 
under Tom Firr, afterwards going huntsman to Lord Ferrers, who had a pack of hounds on the Donnington side of Leicestershire, the country being eventually reclaimed by the Quorn. Gillson then went huntsman to the York and Ainsty, until Mr. Baird gave him the appointment to the Cottesmore. Contemporary with Tom Firr and Frank Gillard, all three of the Leicestershire packs enjoyed an uninterrupted sequence of sport, well served by huntsmen who were the acknowledged best of their time.

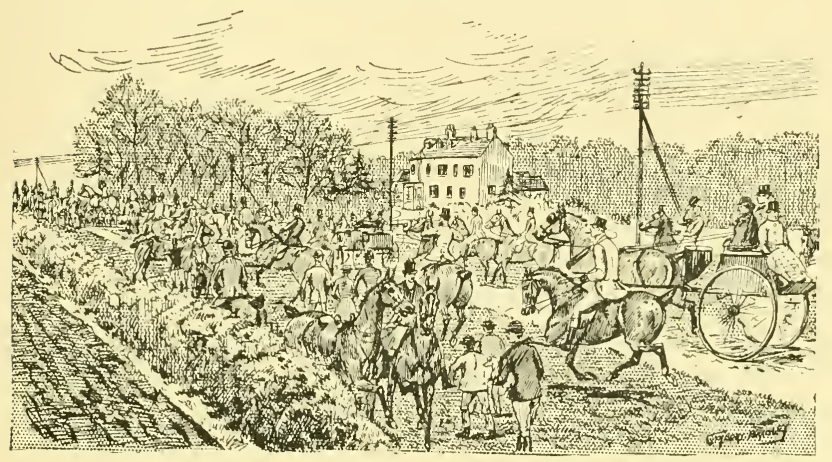

The Opening Day with the Cottesmore at Greetham Inn.

Very workmanlike did the pack look, as they arrived by road at Corby Birkholme, well splashed with mud after doing the six-mile-an-hour trot around Gillson's horse. During Mr. Baird's mastership the hound-van to convey the pack to covert was never used, as was the case in the time of the late Lord Lonsdale, when long distances to fixtures had to be covered, a practice revived again by the present Earl. For these woodland days Mr. Baird had several good grey horses to carry the hunt staff, and there is no better colour to find in a distant landscape. The horses ridden by the Cottesmore 
hunt servants at this period were well-chosen hunters, all pretty much of a stamp, with good backs and shoulders, up to more weight than they were asked to carry. The type of horse Mr. Baird favoured was the model short-tailed, weight-carrying hunter, with capital hocks and quarters to lift out of the deep over a fence. Amongst those the master rode himself were good-looking big horses, the two greys being especial favourites, from which he hunted hounds on occasions when Gillson was laid up by accident. Mr. Baird had a wonderful eye for a country and the line of a fox, his grey horse frequently appearing in the distant landscape ahead at the right moment, when many thought the master was miles behind. Those who attempted to make a short cut by following him were often pounded at the finish by being asked to jump some formidable obstacle over which the master disappeared, possibly his first and last fence during the day's sport. One of these big grey horses was immortalised in a lifesize picture, which was exhibited at the Royal Academy, and presented by members of the Cottesmore Hunt to Mr. Baird, when he retired after twenty seasons of successful mastership.

"Old " Gillson, as he is called-to distinguish him from his two sons, both huntsmen, one at Cottesmore, the other at Meynell-was a man in touch with the country-side and very popular with the farmers. He was rightly regarded as a sound huntsman, and would stick to the hunted fox like a leech-a good exponent of the more leisurely era of the chase. In those days no one seemed to be in such a desperate hurry as they are now ; there was plenty of time to enjoy sport, without being hurried from pillar to post. A hunting community, taking it all through, was certainly more sociable, because 
sport had a more soothing and restful influence; for, moving at a slower pace between times, every one seemed to be on an equality. With the faster era, the poor man on the slow horse finds himself carrying on a stern chase, compelled to finish the day about half-time. But those were happy memories, following the Cottesmore all day on one

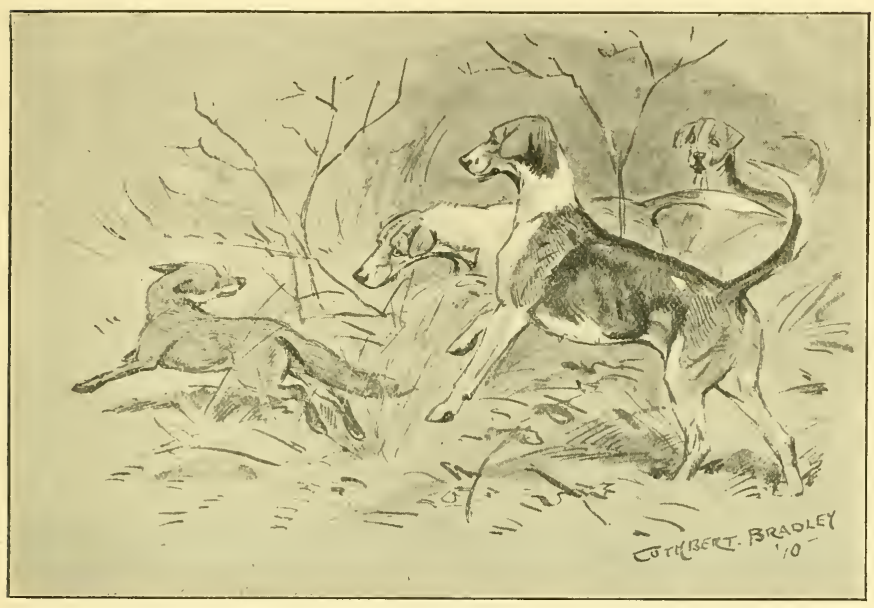

The Find.

horse, the average of great runs seen during a season working out as well then as it does now. The rising generation craves for speed, and perhaps it is only in the general order of things that they begin where their forefathers left off.

As Gillson rode up to the meet, a somewhat portly figure, showing a dash of grey hairs under the cap, which it was his habit to wear slightly on one side, he was respectfully greeted by the assembled crowd of farmers and villagers, eager to have a look at hounds. 
“Marnin', Mister Gillson, we 'ear you've been a showin' great spaurt!" drawled the spokesman to the party.

"Yes, oh yes!" replied the popular huntsman briskly; " now we've come to give your side a turn. Hope you are all well and keen for sport as ever!"

“Yees! we likes a bit of 'untin', seems to 'liven us up a bit in these quiet parts," exclaimed the smiling rustic; "but you see we don't seem to get no younger, and times is bad; it's 'ard work to scrat along and live."

" Never mind about that," replied Gillson, looking learned as a judge; " get on your horse, and you'll feel pounds better when you have followed me all day through Witham Wood!"

The field on these occasions numbered many who made it the excuse to hunt one day in the year, and every horse in the district that would stand up and look through a bridle was pressed into the service of the chase. It is a sign of how times have altered ; for years ago, when living in the Cottesmore country, we remember day labourers would throw down their tools in the field on hearing the cry of hounds, and run for hours in the keenest enjoyment of a hunt on foot. With the spread of education and more material times, this seldom happens now ; besides, as we have said, a hunt moves about much faster, making it impossible.

Riding to Corby pastures, a quick find was proclaimed as hounds opened out in a full-toned chorus which gave promise of a scent. A fox was away on the Belvoir side of covert, and at once the representatives of the two hunts singled themselves out in friendly rivalry. The fun began when Mr. Arthur Hutchinson from Grantham, trotting his roan horse up to a particularly ugly, hog-backed stile, 
jumped it with the greatest ease. Hounds, huntsman, and a good riding field went away in hot pursuit for Irnham Park Wood, and in tuneful chorus hunted their fox through Osgodby Coppice, getting out the far side with a glorious open grass country before them, looking up the valley to Lenton. Nothing could have been more inspiriting. The present Earl of Ancaster looked pleased at the prospect of a ride across his own property; and his eldest son, Lord IVilloughby de Eresby, at that time an undergraduate at Trinity College, Cambridge, was riding along on a steeplechase mare, Maid-of-all-Work.

The two foremost ladies were Lady Margaret Willoughby and Miss Finch, the latter riding a marvellously clever pony. Another who went well on this occasion was Mr. T. Robarts, riding a silvertailed horse. The brook was jumped below Osgodby, and then came a stretch of grass country straight away to Lenton, men being at work on the steeplechase course, making up the fences. The ubiquitous spire of Lenton Church stands out boldly on the sky-line, a striking landmark for the country-side; and we are reminded of a story in connection with this spire, which was restored by the late Rev. Thomas Heathcote, a sporting cleric and a hard rider with the Belvoir. When making the restoration in I875, Mr. Heathcote asked the Duke of Rutland for a subscription. "Why should I subscribe to a church that is not on my property ?" asked the noble master of Belvoir. "Because it is such a good landmark when your hounds run!" replied the fox-hunting vicar; and the Duke promptly sent $£ 5$ towards the restoration of the spire. When Mr. Heathcote died in I883, the Earl of Ancaster, patron of the living of I-enton, pre- 
sented it to my father, the late Rev. Edward Bradley, better known as Cuthbert Bede, author of "Verdant Green"; and though not a follower of the

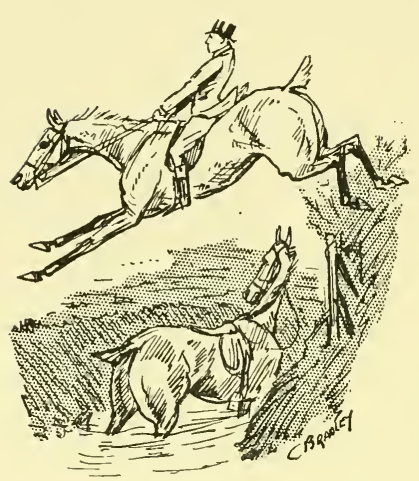

In or Over. chase, his pen contributed many a note on hunting lore and Belvoir Hunt history. By the irony of fate the Belvoir steeplechase meeting was established over the stretch of grass country below Lenton Vicarage, just a year after Mr. Heathcote's death, and flourished for over twenty years, much of the success of the management resting with "young" Mr. Thomas A. R. Heathcote, the eldest surviving son of the late vicar.

After crossing the road that runs between Lenton and Ingoldsby, Gillson and the select division with hounds had some stiffish fences to jump, for it is a good bit of bullock-grazing country. Just below Hanby, hounds hovered by the far-famed Lenton Brook, over which they carried the line, and Gillson " had a go at it," landing with nothing to spare. Two fields farther on they got off the grass on to cold strong plough, and when near Sapperton Wood were completely beaten by scent, after making a six-mile point over a sporting line of country, which pleased the riding division immensely.

It was said that something like three-and-twenty years previously the Cottesmore had run this identical line of country, and on that occasion joined forces with the Belvoir. 
We all know the pleasures of anticipation, with the corresponding disappointment in realisation, and when we arrange our plans for a red-letter day, fickle fortune is sure to upset the best of them. But so pleased were the Cottesmore followers with the day's sport in the Belvoir country, which was fairly pronounced equal to anything that Leicestershire could offer, that a fortnight later they chartered a special train, and with men, horses, and hounds came again to Corby. Of fortune's cap the Cottesmore must have been the very button, for that jade decreed that plans should be realised, and a run put on record that eclipsed the gallop of the previous fortnight. The field representing the Cottesmore included Mr. W. Baird, the master, on a grey; Gillson, on a bay; and his first whipper-in, George Jull, who turned hounds to him for ten seasons, and then went huntsman to a northcountry pack; Mrs. Baird, the Earl of Ancaster, Lord Willoughby de Eresby, M.P., Lord Edward Spencer Churchill, brother to Lord Randolph Churchill, Captain and Mrs. Blair, Mrs. Cecil Chaplin, Mr. Herbert Gosling, Mr. Jackson, Mr. Cecil Noel, Mr. Gilbert Peacock, Major Henry Wickham, the then reigning master of the Fitzwilliam; Mr. Joplin, Mr. Henry Hunt, Mr. George Hunt, and the Rev. J. Mirehouse. The Belvoir division

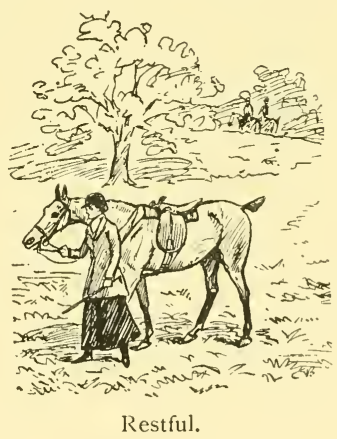
included Sir Hugh Cholmeley, Major W. Longstaffe, Major Fritz Amcotts, Mr. Ernest Chaplin, Mr. Thomas Heathcote, Mr. Edgar Lubbock, Mr. T. Robarts, Mr. Arthur Hutchinson, Mr. F. Parker, 
Mr. J. H. Bellamy, and Ben Baxter, the hunting blacksmith from Irnham, who for many years was an institution, putting on shoes while out hunting, which he carried in a bag on his saddle.

It was a fair hunting morning, and the ground in splendid going order, so that horses could gallop and jump on the top of the springy old turf. A move was made to Corby pastures to try, if possible, to find the same fox, but he was not at home; and Irnham Park Wood was drawn in silence except for Gillson's voice as he encouraged the pack, with a "Yoi over, lads! yoi wind him! eleu wind him there!" At last, when the extremity of the covert was reached, a hound spoke, and the Solons of the pack confirmed the note by coming together with a rattling chorus! "Tally ho! gonna awai!" rang out the far side of covert, from some one frantically waving his hat in the direction of Osgodby Coppice. A blast on Gillson's horn quickly had the pack away from the thicket, crossing two fields before threading Osgodby Coppice, through which they shot without hesitation, and we galloped in hot haste down the middle ride. It was evident at once they had roused the same fox which led the previous gallop, complimentarily named "Baldwin," after the professor of flying who was then giving exhibitions at the Alexandra Palace. The celebrated ex-jockey the late Mr. Henry Custance was another who adopted this name for a very speedy mare, Miss Baldwin, much fancied for the Melton Hunt Cup this same year, but, as the report afterwards said, "Although running well, she had not quite enough gas to win!"

Once again Lenton Church spire in the far distance was the point to ride to, our pilot on this occasion being Major Fritz Amcotts, one of the best 
that ever rode with the Belvoir, well carried by a red-roan mare, Gingerbread, an undefeated fencer, who subsequently became the property of Lord Henry Bentinck. The line was exactly the same, fence for fence, across the steeplechase course below Lenton, taken the opposite way to which it is ridden in a chase. The guard rails were up and wings to the fences, in readiness for the meeting which took place that same week, the workmen giving a cheer and waving us on, as we rode by; for the fox had passed within a hundred yards of them, taking a line about a quarter of a mile parallel and west of the far-famed Lenton Brook. It was an occasion when all seemed to be going well, for hounds who never required much help were travelling in a straight line over an undulating grass country, so that to hesitate was to be lost for the day. Well in front with the master was Lord Willoughby de Eresby, again riding Maid-of-all-Work; Lord Edward Churchill, Mr. Thomas Heathcote, on a mealy bayhorse, "the Earl"; Mr. Arthur Hutchinson, Mr. George and Henry Hunt, Mr. Ernest Chaplin, Major W. Longstaffe, and Mr. Edgar Lubbock. Very determined too was Mr. Jackson, riding a roan mare, going a line of his own, getting some very strong wide fences below Lenton Vicarage when in the pastures near the brook. Mrs. Baird, Mrs. Blair, and Mrs. Cecil Chaplin held good places in this stirring gallop; and the hunting blacksmith was useful, riding his pony at the tail of the hunt, picking up Lord Willoughby de Eresby's hat, which he lost when jumping under a tree.

Away hounds silently raced out of one parish into another, away from the grass on to the plough, below Hanby and Sapperton village, driving along at a fair hunting pace to the Heydour Southings, 
near the road which runs from Boston to Grantham. In the covert Gillson cast about for his fox, and just when hope was nearly abandoned, some one viewed him stealing back towards Newton. In a twinkling Gillson had them on the line, and away we went gaily as before, passing Dembleby Thorns, two fields on our left, to Osbournby Hill Top Plantation, where again the huntsman had to lend assistance. Leaving this covert, hounds turned down the hill, and, entering the village of Osbournby, marked to ground under a well-known stick heap, which has offered sanctuary to a hunted fox on many occasions.

The time of this fine hunting run was one hour and thirty-five minutes, absolutely straight up to Heydour Southings, where they turned sharp righthanded for Osbournby, and it only wanted a brush at the end to make a good finish. A terrier failing to bolt the fox from his stronghold, Mr. Baird gave the order for kennels, some twenty-five miles distant, and with the aid of local pilots the best route was arrived at. Some of those whose horses showed signs of having had enough turned to Grantham, ten miles away, to catch the nearest train, get a feed and dry clothing from their Belvoir friends. The hounds with Gillson, after "refreshing" at Newton House, the home of Mr. Thomas and the Miss Heathcotes, returned by road to kennels at Barleythorpe, near Oakham.

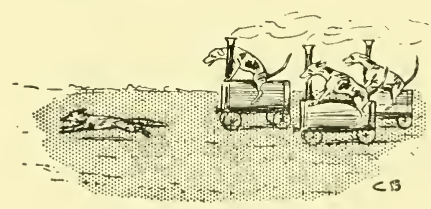

Going like steam. 


\section{CHAPTER V}

\section{A HUNT WITH THE DUKE OF BEAUFORT'S HOUNDS}

Whyte-Melville's verse on the Blue and Buff-The origin of the four great hunts-Whyte-Melville's country-The Duke of Beaufort's hunt and the Badminton kennels-Beaufort Justice-The influence of Badminton blood-Badminton Rapture, 1899-Successes at Peterborough - The 9th Duke of Beaufort, inaster and huntsmanThe Great Wood run, 1881 - The young Marquis of Worcester-The "Blue" Duke and the hunt uniform-Will Dale's record-The Duke and the big dog pack-The hound Vaulter, I 897 - The pick of the pack - The Duke of Beaufort's lunters-The Badminton stablesThe field out at Chavenage Green-Union Gorse-Away over the stone-wall country-A nine-mile point-A long hunting run and good hound work.

"How they drive to the front! how they bustle and spread,

Those badger-pied beauties that open the ball!

Ere we've gone for a mile, they are furlongs ahead;

In they pour like a torrent o'er upland and wall.

There is raking of rowel and shaking of rein

(Few hunters can live at the Badminton pace),

And the pride of the stable's extended in vain,

And the Blue and Buffs are all over the place."

-Major G. J. Whyte-Melvillf.

THE fame of fox-hunting is linked with the history of four noble families, owners of large estates, whose ancestors established packs of hounds when the necessity ceased to keep a troop of armed retainers under their roof. In this way the Badminton, Belvoir, Brocklesby and Fitzwilliam sprang into existence, and each has the advantage of belonging uninterrupedly to one family, extending over a period of one hundred and fifty years. The oldest establishment is said to be the Badminton, which has flourished under five successive Dukes of Beaufort, well managed in the kennel by huntsmen, 
the acknowledged best of their time, serving long tenures of office. The mastership of a noble family lends distinction to a hunt and a community, for there is something alluring in the idea of the great lord of the manor thus providing for the amusement, not only of his own tenants and dependants, but also for the whole country-side. It is a remnant of that powerful splendour which enabled the old feudal lords to carry into battle their own followers. Under the mastership of the present and ninth Duke of Beaufort, everything connected with the Badminton Hunt is done in princely style, sport in the field being conducted with state and decorum.

The fame of the Duke of Beaufort has been sung by Whyte-Melville, who enjoyed his best sport with this hunt, praising the hounds over a stone-wall country, and his last resting-place is on Badminton soil. One of the largest countries, extending over three parts of Gloucestershire, it is at the same time one of the best, offering every variety and condition of hunting. On the Severn side, next the Vale of White Horse country, there is grass, second only to the pastures of Leicestershire, and near Beckhampstead hounds can race over the downs, which are fine as any in England. The intermediate portions are fenced with stone walls and every variety of fence to test the ability of a hunter; the large tracts of forest being excellent nurseries for foxes, and exceptional schooling ground for hounds. The Badminton country is full of foxes, quite seventy brace going to make a cubhunting bag, and the average of hunting days exceeds that shown by most packs.

As might be expected, the kennel is one of the largest in area, with day-yards to accommodate 


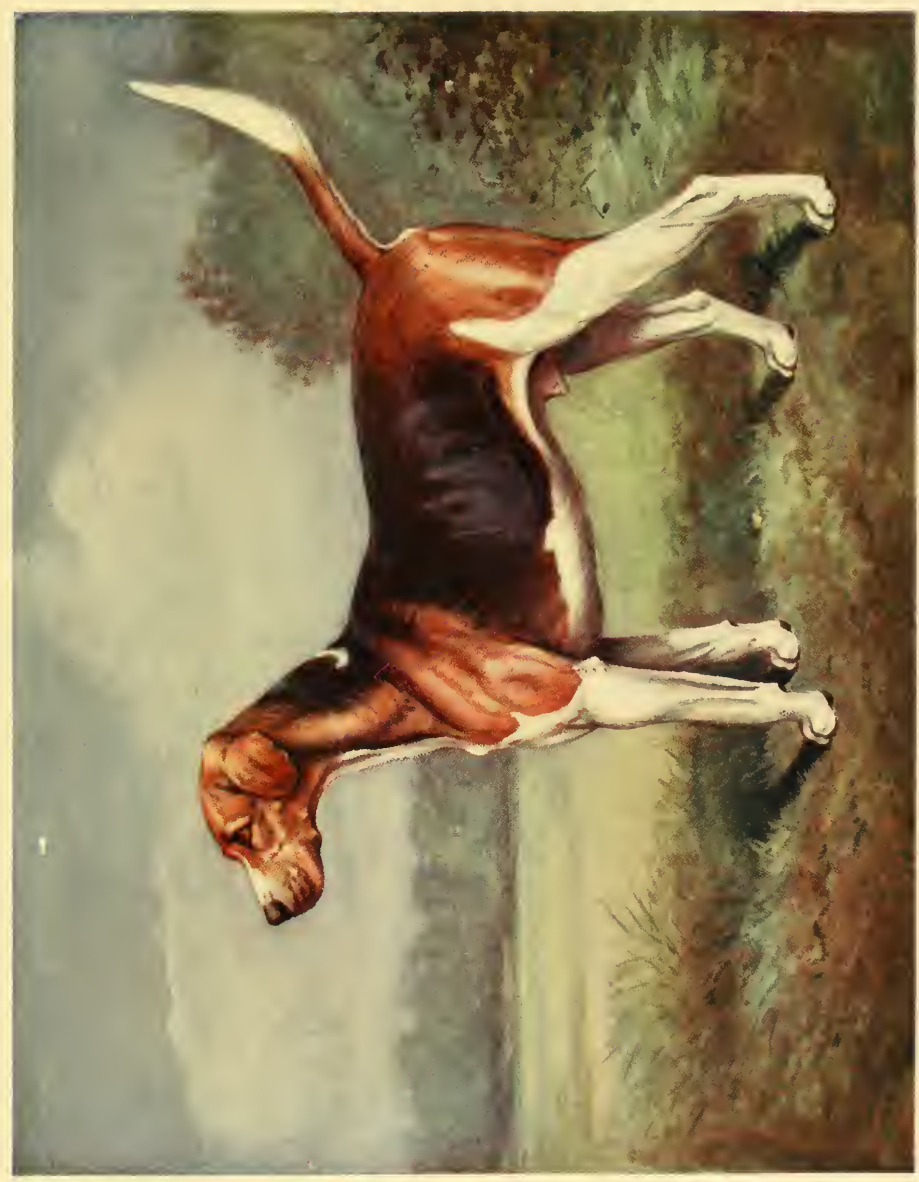

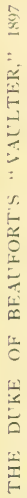



the best part of a hundred couple of hounds, the wherewithal to hunt six days a week, commencing the middle of August, finishing in April. The extent of the country allows of two different packs and two hunts being out on the same day, his Grace and Will Dale hunting one or the other, so that the equivalent of some seven or eight days may be said to count to a week's sport with the Badminton. A large type of hound has always been favoured by the Dukes of Beaufort, measuring quite twenty-four inches, being best adapted for taking the stone walls in their stride. "The Beaufort Justice" is one of the great hounds of the last century, whose blood laid the foundation of much excellence, for he became the patriarch of the pack;

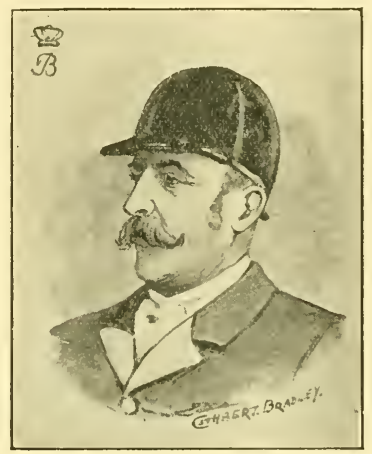

The Duke of Beaufort. the badger-pied colouring, which is a distinguishing feature of the Badminton, being attributed to his influence in the kennel.

Belvoir, Badminton and Fitzwilliam exchanged courtesies, with great advantage to each, and $\mathrm{Mr}$. T. W. Dale relates in his history of the Hunt, that, "In I8oI, Belvoir borrowed a hound from Badminton, named Topper. This hound is one of the roots of the family of which Rallywood, Weathergage, Gambler, Dexter, and Dasher are famous representatives." The late, and present Dukes of Beaufort retained their old sorts, but brought the kennel up-to-date with valuable purchases of doghounds from Lord Portsmouth in I876 and Mr. 
Austin Mackenzie's Woodland Pytchley pack in I899. To-day the Belvoir influence is noticeable in colouring and quality shown throughout the pack, which present a very sorty appearance in the field without losing anything of the size and stoutness so characteristic of the kennel in the past. As Will Dale remarked, "None but the best hounds are of any use in the Badminton country to catch foxes," and a very high standard of excellence has always been maintained. Amongst successes gained at Peterborough the kennel has done well of late years with bitches, going back to I899 when Rapture ('99), by Councillor, d. Rarity, d.s. Rubicon, was awarded the championship. This was quite one of the old Badminton badger-pied sort, a lengthy bitch with a thin stern, great bone and muscular development. Again in I904 two couple of bitches won first prize, named Drapery ('02), Droskey ('02), Dagmar ('03), and Likely ('03), combining the old Badminton blood and that of the Belvoir, through Mr. Austin Mackenzie's Dexter. These two couple have the size and scope of dog-hounds, with the distinguishing Belvoir tan, and are typical of the sort that now occupy the benches at Badminton, from which so many celebrities have sprung.

The present Duke of Beaufort is heart and soul in hunting, and when Marquis of Worcester established his fame as a gentleman huntsman of the very first rank, at that time holding a commission in the Horse Cruards. As far back as I868, when Tom Clark retired from office, the Marquis of Worcester undertook the duties of huntsman for the family pack. For forty seasons his Grace has hunted regularly four and six days a week, a marvellous record which is not approached by any professional huntsman of our time. In the autumn 
WITH THE DUKE OF BEAUFORT'S HOUNDS 75 of I9o8, to every one's regret, the Duke of Beaufort took a heavy fall and broke his leg, which kept him out of the saddle for the rest of the season. His Grace will always be noted for having hunted the hounds when they scored the celebrated Great Wood run on February 22, I $87 \mathrm{I}$; a run which ranks with the Billesdon Coplow of the Quorn, or the Pytchley Waterloo day, when Mr. Anstruther Thomson was master. It went to prove the advantage of a master being his own huntsman, in a position to note the work done by each hound, because many of the dog-hounds that did brilliantly on that occasion developed into sires of great service to their kennel. In the opinion of the bestjudges in England, the Duke of Beaufort

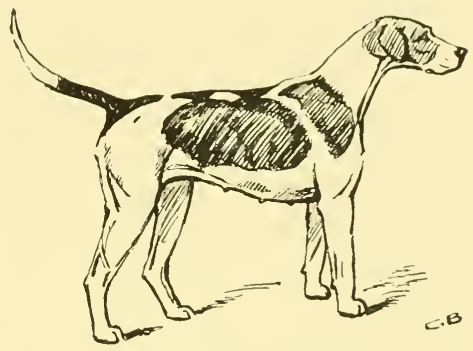

Rapture ('99). Champion at

Peterborough. is considered "the model of a master who hunts his own hounds." The young Marquis of Worcester, born in I9oI, has also shown a remarkable talent for the chase, handling a pack of beagles at a very early age with great skill, and it is a congratulation that the future of fox-hunting and the Badminton hounds, have a promising scion of the noble family training on.

In I802, when the sixth Duke came into the title, he followed in the footsteps of his father, hunting the Badminton country with Philip Payne as huntsman, who had earned a name with the Cheshire and the Cottesmore. The sixth Duke was known as the "Blue" Duke-probably from introducing the hunt uniform of blue, with buff facings- 
the servants wearing green, as they do to the present time. To those accustomed to see the orthodox scarlet of the chase, a field of three hundred riders wearing the blue and buff might be supposed to have a disappointing effect. But the display is brave as anything to be seen in Leicestershire, the Duke's hunt being one of the best-dressed fields anywhere in the United Kingdom. The late Duke was always most particular about the attire worn by his followers, showing, as it does, a compliment to the master and his pack. One saying attributed to him is to the effect that when a man goes hunting he should put on his best clothes, even if it be his Sunday suit.

Will Dale, the present huntsman and wearer of the green uniform, is keenness personified, and one of the cheeriest of men. Always thinking of hunting, no day is too long for him in a week of six days' sport, and a year of nine months' active work in the field. The knowledge he possesses of foxhound pedigrees and the leading lines of past generations which are the foundation of excellence to-day is truly marvellous. Huntsman to the Earl of Yarborough at Brocklesby from I884 to I896, Will Dale was selected by the Duke of Beaufort in I8g6 to manage the kennel at Badminton, and help him in the active duties of the field. His Grace hunts the big dog-hounds on Tuesdays and Fridays, Dale hunting a mixed pack on Mondays and Thursdays, the bitch pack coming out on Wednesdays and Saturdays, with occasional bye-days, when two packs are in the field.

To see the Duke of Beaufort's hunt start from kennel on a hunting morning is a scene very typical of the best that English country life has to show us. The avenue of stately trees, through which we get 
WITH THE DUKE OF BEAUFORT'S HOUNDS 77

a glimpse of the fine mansion, line up from the kennel gates with the road winding its way across the park. On an occasion at the beginning of season rgo4-5, when staying at Badminton to paint a picture of two couple of Peterborough winners, his Grace most kindly gave us a day's hunting in the stone-wall country around Chavenage

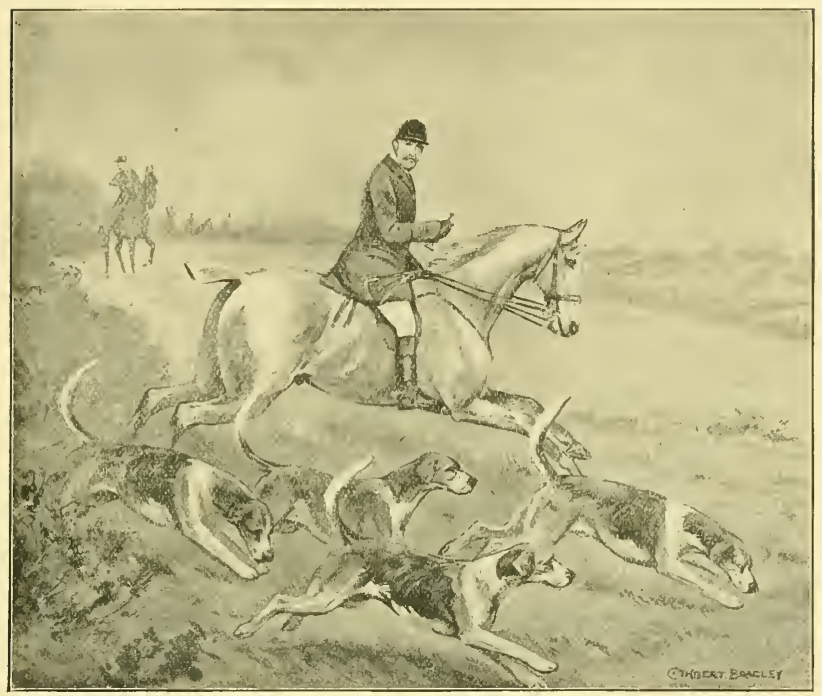

The Duke of Beaufort on Grey Skin.

Green. Heavy rain had improved the going and it was a good scenting day, the Duke of Beaufort handling the big dog-hounds, who put a fine hunting run to their credit. The pack for the day was twenty couple, presenting a grand appearance, standing all twenty-four inches, showing immense bone, depth of brisket and back ribs. Amongst the veterans of the pack there was Vaulter ('97), by Belvoir Vaulter ('94), a son of Hermit and Vanquish; 
and Vaulter's dam was Mr. Austin Mackenzie's Lightning, by Belvoir Game Boy ('84). Vaulter ('97) was pronounced the best stallion hound at Peterborough in I899, a massive 24-inch hound with beautiful quality and Belvoir colouring. Girthing $3 \mathrm{I}$ inches round the heart when in hard condition, he had good ribs, and weighed 79 lbs. Of him Mr. T. F. Dale says in his history of the Badminton Hunt, "Vaulter combines the Belvoir Weathergage grafted on Blankney blood, and finds many of his kin at Badminton, for of Blankney blood at its best the Badminton kennel has many strains. Did not Contest come from Lord Henry Bentinck to Badminton, and please the eighth Duke greatly by his work ?"

Others with whom we renewed acquaintance were Victor and Woldsman, winners at Peterborough; Rataplan and Rasselas, by Dexter, a son of Belvoir Dexter, from Rapture, the old champion badger-pied bitch. Then there was Archer, a very nice dog by the Brocklesby Auditor; Diver and Discount, by Carmelite; Palafox, by Paradox; and Comrade, the Duke's favourite, a bitch by Counsellor; fine dashing hounds with the stamp of Belvoir on their legs and feet, looking all over like carrying on the fame of the kennel.

The Duke of Beaufort had four horses in the field for his own riding, all weight-carriers, the covert-hack a long, low, snaffle-bridle chestnut doing the twelve miles to the meet over hounds. The hunter for the morning was a short-legged brown horse; and the pair in reserve for the afternoon were Grey Skin, a big grey standing seventeen hands, two inches, bought from Mr. Muntz, a fast horse with top weight in the saddle, and Rathkeale, 
a commanding-looking brown horse, which carried his Grace in King Edward VII.'s Coronation Procession, I902. It was supposed to be an off-day for Dale, but nothing short of disablement would persuade him to stay at home, so he was out in the capacity of whipper-in, riding an oldfashioned white horse. With two whippers-in, and a troop of green-coated second horsemen, the cavalcade behind the pack presented an imposing appearance as we trotted through the park on the way to the meet. The Badminton stables are of vast extent, the stalls and boxes accommodating over eighty hunters and harness horses, many hailing from Mr. J. H. Stokes, of Market Harboro'. Latterly, motors have been added to the establishment, and are often used by the Duke and his huntsman when going to covert. Another addition is a stud of hunting ponies for the young Marquis of Worcester, and the Ladies Blanche and Diana Somerset, who with the Duchess of Beaufort are frequent followers when the meets are within distance.

The meet at Chavenage Green is on the Tetbury side of the country, north of Badminton and bordering on the Cotswold. A large field were out, giving us the first sight of the famous blue and buff uniform, there being but one scarlet coat in the assemblage, and that, if memory serves aright, was worn by Captain P. A. O. Whitaker, ex-master of the Oakley, who was riding a thoroughbred type of chestnut. Amongst those out were Major Cosma and Mrs. Little, Captain Gilbert, Colonel and Mrs. Henry, Mr. Edward Henry, Mr. A. M. Wilson, Mr. and Mrs. Williams of Bradley Court, Major Gist, Colonel Turnour, Mr. Harding, Captain Percy and Mrs. Whitaker, Mr. D. Lindsay, Colonel Haydon, Mr. E. S. 
Prince, Drs. Alfred Grace and A. H. Grace, Dr. Mellish, Mr. Arthur Rich, Mr. C. Rich, Mr. J. Rich, Mr. W. Crew, Mr. J. Large, Mr. Morrice, Captain and Mrs. Adam, and many others, besides a large contingent of farmers.

Moving away from the meet, the first draw was Union Gorse, a typical covert in the heart of the best stone-wall country in Gloucestershire - a rough piece of fox-ground of low scrub covering several acres and surrounded by a stone-wall. His Grace threw hounds in, while Will Dale rode to the far end to get a view. An old dog-fox was quickly on his legs and bounced over the wall in full sight of the field, Will Dale on the silver whistle notifying the fact that he was away. A second later his Grace came galloping up blowing his horn; there was no halloaing-for the noble huntsman hates noise-and in the quietest manner possible had his pack quickly out of covert to a flying start. Getting away on excellent terms with their fox, they ran at a splendid pace by Beverstone down to Boldoun Wood. Scent was breast high, and for an hour and a half they bustled along, making a good ninemile point nearly to Corston. Large fields of light heath country, with luxurious crops of old seeds and roots, appeared in the extensive view, grand galloping ground mapped out by a tracery of stone walls. Scent served well, and driving their fox right through Boldoun Wood, with a rattling chorus they went away again as if going for the hills. Turning left-handed, the hunted one passed the big Silk Wood on the right into the Rhododendron covert, and so on through Weston Birt Park-the seat of Lieut.-Col. George L. Holford, C.V.O., Equerry in Ordinary. The pace for twenty minutes was pretty severe, 
and strung out the field, but those nearest to hounds included Mr. A. M. Wilson, well carried by a favourite hunter, and the Messrs. Rich, of polo fame, Captain Percy Whitaker, and others.

In Weston Birt Park hounds experienced their first check; but the Duke summed up the situation, and cast them round the Garden Plantation, where

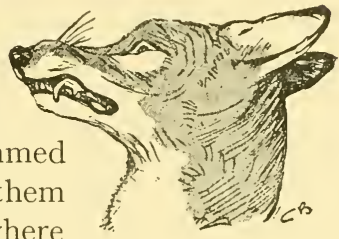
they hit off the line, and again streamed merrily away. The nature of the country altered, fences taking the place of stone walls in the journey to Easton Wood, a district wonderfully well gated, so that a larger section of the field than is usual were able to get to hounds, and enjoy the sight of some splendid work during the latter part of the hunt, which was at a slower pace, necessitating the huntsman's assistance. Crossing the Malmesbury and Sherston Road, just above the Old Fosse Way, they persevered on to Hyam Wood, where a slight check occurred, until the Duke cast down towards the river, where they recovered the line and ran on to Malmesbury Common. Here a man with a dog headed the fox, causing complications, but after being held round Foxley Grove, they ran on to Bradfield Wood, and a great hunt ended with slow work by West Park, away in the direction of Corston, where all trace of scent vanished. Consulting the map, it is a nine-mile point as the crow flies, and a good many more as hounds ran. The view opening out before us was one of extensive woodlands, with plenty of trees in the hedgerows, most striking in their autumnal colouring, for the leaf remained until late in November. 
Another good hunt in the afternoon from Captain Holford's coverts ended with blood, and it was late when we turned for the kennels at Badminton after a most enjoyable day in the Duke's country, which is associated with the lives of so many famous sportsmen. 


\section{CHAPTER VI}

\section{GOOD GREY HUNTERS}

Two qualities of grey horses-A surplus of grey horses left in England -Colour and climate-Colour and the elements-Whole colours for the foreigner-Greys favourites-Pedigree of a grey Arabian horse-Few thoroughbred greys-Gimcrack, 1760-Steeplechasing greys-Sir Reginald Graham's opinion on colour-Mr. Merthyr Guest's and the Blackmore Vale greys-Mr. C. B. E. Wright's greys and chestnuts at Badsworth-The Earl of Lonsdale's chestnuts and grey horse Marble and White Cap-Frank Gillard's Belvoir Grey Bob-Will Wells "makes" Grey Bob-The Hon. Lancelot Lowther and the Belvoir Grey Bob memento, and his The Rake, by Haymaker-The Rev. J. P. Seabrooke's Top Bar-Sir Gilbert Greenall's greys, Fox-catcher, Phantom, and Bubbles-Mr. E. W. Griffith's Grey Friar-The Duke of Beaufort's Grey Skin and Will Strap -Grey John, the horse of a lifetime-Captain H. T. Timson's grey -Some cheap grey horses-The wedding greys.

"The Grey Mare is the better horse."-Butler.

MANY grey horses are to be seen out hunting, and it is hard to find a bad one amongst them-a sweeping assertion that we would not commit ourselves to about any other colour in horse-flesh! But this may be half explained by the fact, that amongst grey horses there seems to be no medium quality; they are either sterling good ones, or their commonness is so apparent that they are drafted for utility purposes. The best grey horses undoubtedly show a strain of Eastern blood, generally in a brainy, well-cut head, so that they can claim a pretty long descent, calling to mind the spirited lines written by Lindsey Gordon-

"We, too, sprung from mares of the prophet of Mecca,

And nursed on the pride that was born with the milk, And filtered through Crucifix, Beeswing, Rebecea,

We love sheen of scarlet and shimmer of silk." 
Some one made the remark when riding in Leicestershire: "What a number of grey horses are out to-day!" "Yes," replied a cynic, who never rides anything but chestnuts, "they are the only horses left in the country. The foreigners buy up all the good horses of every colour except grey, and the South African War took anything with four legs, so long as it was any colour but grey."

A trite saying, that "a good horse is never a bad colour," is little less than an evasion of the question, for there is literally more in colour than at first meets the eye. Colour often is a matter of climate, though this is not a hard-and-fast rule; but in Arabia there is a prevalence of white or grey horses, in Russia black, in England, Germany, and France bay is the colour most often seen. Some three centuries ago the colour of a horse was supposed to be influenced by the four elements, earth, air, fire, and water. Horses that were black, dun, or russet were said to have more of the earth in their disposition, and were credited with being heavy and faint-hearted. Even to-day the opinion of the racing fraternity is that there never was a good black mare on the turf, though we know of some in the hunting field. The brown bay has always been held in estimation, and experienced judges say that there are more good horses of this shade than any other, being pleasant and nimble, suggestive of the air. Chestnuts are representative of fire, generally being high-couraged horses, hot-headed, and excitable in temperament, "ready to go until they drop," as the saying is. White and the paler shades were supposed to be influenced by the watery element, and even to-day horses of these colours or with white markings are altogether avoided by foreign buyers. At the Berlin Horse Show in the 
summer of I\&go this fact was particularly noticeable, and in a show of I027 exhibits there was hardly a grey horse to be found, or any that had conspicuous white markings.

Perhaps the verdict of popular opinion-and it may generally be accepted as the right one-is in favour of the grey horse. The dapple-grey is universally admired, inspiring many a poet to sing his praises in tuneful metre, and their eastern origin lends itself to romance, besides enduing them with exceptional brain power, constitution, and endurance. In an old book of anecdotes we stumbled across a curious pedigree of a grey Arabian horse, well known in Nottinghamshire many years ago. The following is a literal translation of the pedigree : "In the name of God, the merciful! The cause of the present writing is, that we witness that the grey horse Dervish, of Mahomet Bey, is the first breed of Nedgdee horses, whose mother is the grey mare Hadba the famous, and whose father is the bay horse Dahrouge, of the horses of the Benhibaled. Ve testify in our conscience and fortune that he is of the breed concerning which the Prophet has said, 'The true runners when they run strike fire: they grant prosperity until the day of judgment.' We have testified what we know ; and 'God knows who are the true witnesses.'" Followed by six signatures-a formidable warranty with a new purchase, in all conscience!

Although grey horses can be numbered by the score amongst the best that go hunting, yet there are very few thoroughbreds of this colour, the Derby having been won but twice by grey horses-Gustavus in I82I and Frederick in I829. Amongst celebrities in turf history, Gimcrack, a little dapple-grey horse, bred in I760, and so much admired by 
Admiral Rous, that he presented a picture of him to the Jockey Club, is the only English racehorse after whom a still existing association is named-the Gimcrack Club at York, founded in I766, attests his excellence and prowess. Somehow there is a prejudice against greys that they lack speed, but amongst the well-known grey performers in the annals of steeplechasing can be mentioned Grey Skin, Peter Simple, the Greyling, Cigar, Grimaldi, Prince le Boo, Comus, Hesperus, Scots Grey, Bob Ridley, and Downpatrick.

To show off a scarlet coat there is no colour so telling as grey, and what a good colour it is to find in the landscape! Where is the master of hounds who has not a good grey horse or two in his stud ? The best of colours to lead the procession, and as a rule the favourite mount when there is any work that wants doing! Some good judges stick to a colour, just as they do to a stamp, when choosing their horses. "Hunters of a colour are not difficult to find," says Sir Reginald Graham, in his interesting book of hunting reminiscences; "but the difficulty is to find the money to buy them with." When Mr. Merthyr Guest was master of the Blackmore Vale, hunting them at his own cost from I884 to Igoo, he mounted the whole of his staff on grey horses, giving a very striking appearance to a hunt which has a large percentage of woodland. Mr. C. B. E. Wright was another who favoured the colour, and when master of the Badsworth, from 1876 to I892, had a stable of greys and chestnuts, making a very pleasing contrast.

The Earl of Lonsdale's colour is chestnut, and we have seen more than sixty stabled at Barleythorpe to carry the Cottesmore hunt staff, the majority being able to claim a birthright in the Stud 
Book. When master of the Quorn, Lord Lonsdale had two grey horses of great character which carried him when he hunted hounds. White Cap was a long-tailed horse nearly thoroughbred, and could gallop with top weight in the saddle; he was purchased for 625 guineas at the sale of Mr. E. D. Morgan, who hunted from Melton. The other grey was Marble, an upstanding, short-tailed horse

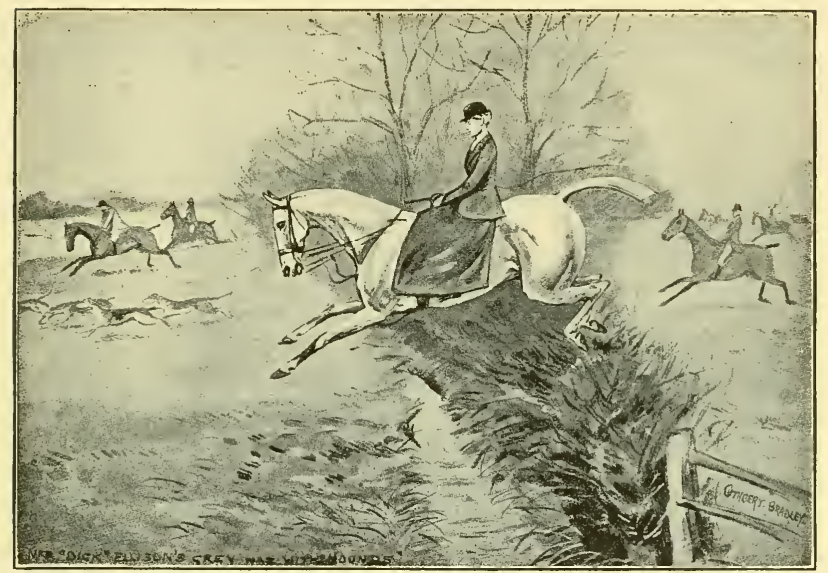

Mrs. R. J. Ellison's Grey.

bought from Major W. Longstaffe of Ponton Hall, by Grantham. When riding this horse, Lord Lonsdale jumped the stone wall at Kirby Gate, which when measured was found to be five feet high.

One of Frank Gillard's favourite mounts, he relates in his reminiscences, was a white horse Grey Bob by Light Bob, just the stamp for Leicestershire, standing a trifle under sixteen hands on short legs, possessing great beam, bone, and muscular development, with unusual freedom. Belvoir Grey Bob earned a place on the scroll of fame, for he carried 
Gillard before a hard-riding Leicestershire field for eleven seasons, and that without ever giving him a fall that could be attributed to the fault of the horse. On a certain Ash Wednesday, with an enormous field out, a stranger lady crossed Grey Bob at a fence, and the consequence was-upset horse and rider. However, she never stopped to pick him up, and probably thought there were plenty more huntsmen to take his place!

About the early history of this good grey horse, Will Wells-huntsman to the Hertfordshire hounds-who left a lasting record when whipperin to the Belvoir in the eighties, writes a most interesting letter, which appears in the "History of the Belvoir Hunt," by the Rev. T. F. Dale. Here Will Wells says, "I had five horses for five days at Belvoir, two a day, and only had one sound one, that was Grey Bob. This horse had got the better of the men who had ridden him; he would only go to Croxton Park and back! We were just going to exercise with the hounds when I said to Gillard, 'Master, I should like to get on that grey horse, for he is being spoilt.' 'So you shall, Will,' he replied, 'if the groom will let you.' So I did. It was then half-past nine in the morning, and I sat on his back until half-past four that afternoon. When I took him home, the stud-groom said, 'Well now, you shall have him at the kennel,' and so I did. He would get you under trees, into ditches, or throw himself down, but I soon got him out of that, and rode him that season, nothing being too big for him." Gillard used to say that if Wells had not taken him in hand, he must have been sold for a song as an incurable. In the second season Gillard took to the horse, and liked him, so that Will Wells did not get him again! 
By some mischance the horse was drafted from the hunt stables, and reappeared the following season carrying his new purchaser. Gillard was naturally much distressed at losing his old favourite, and this got to the knowledge of the Hon. Lancelot Lowther, who, without saying any more about it, bought the horse and presented him as a personal

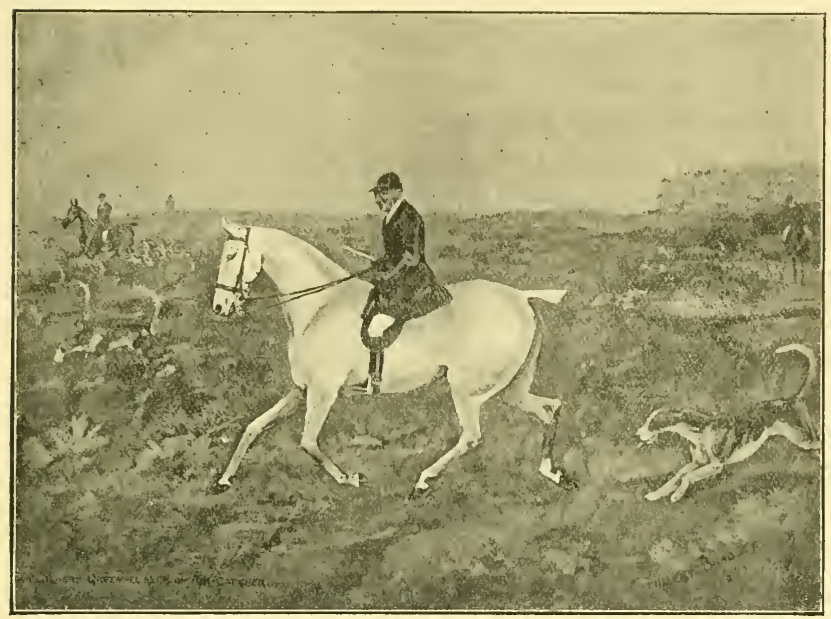

Sir Gilbert Greenall on Fox-catcher.

gift to Gillard. The only conditions were that when Grey Bob died his fore-feet should be sent to the donor, and this was of course gratefully done, one of the hoofs being again returned to Gillard, mounted as the base of a massive silver candlestick, bearing a suitable inscription-“" 'Grey Bob,' ridden by Gillard from November I88I to April I892."

About this time the Hon. I.ancelot Lowther owned a good-looking, short-tailed grey horse, rather inclined to be swan-necked, named The Rake, by Haymaker one of the right sort, who could do as 
much hunting as any two other horses. For nine seasons he was a brilliant performer in the field, with all three of the Leicestershire packs, often carrying Mrs. Lowther. A horse of exceptional quality, standing on short legs, he was a big, bold jumper; on one occasion, when ridden by Mr. Lowther, clearing the brook below Hambleton, which measured 25 feet. His owner refused $£ 700$ for him, and the late Mr. Henry Custance, in his book of "Racing and Hunting Reminiscences," pronounced The Rake to be one of the three best hunters he ever saw in the field, the other two being Lord Lonsdale's Quirk and his own horse The Doctor. When The Rake's hunting career came to an end in I893, Mr. Lowther said, "He gave me three falls running the first day I rode him, but never put a foot wrong afterwards."

Another famous grey of the past was Top Bar, a horse with a funny temper, ridden at the top of many a stirring gallop across Leicestershire by his resolute owner the Rev. J. P. Seabrooke, then vicar of Stonesby. On a memorable occasion in I892, Top Bar carried his reverence in the Red Coat race at the Melton Steeplechases, a scarlet being borrowed for the race, and although he showed the way for half the journey, he was not up at the finish, Mr. Grenfell winning on Mr. C. D. Rose's Carnation. Poor Top Bar dropped down dead in a grass field during the following summer.

Amongst the seventy hunters that have occupied the boxes at Woolsthorpe since Sir Gilbert Greenall undertook the mastership of the Belvoir, fourteen seasons ago, many grey horses of beautiful outline have been seen. Probably the highest-priced grey was Fox-catcher, a fast good hunter and beautiful mover, bought for a large sum at Captain Steed's sale, when he left the Rugby country, where 
the horse was known as a great performer. Foxcatcher figures in a design for the Royal Show at Gloucester, June Igog. Another good-looking grey of a strong type, which carried the master for some nine seasons up to I908, was Phantom, a well-known performer on the Lincolnshire side of the country. A beautifully topped horse, he was very much back at the knees, but they proved good wearing legs, clean and fine as the day he was foaled right up to the last, when he broke down at twenty years of age through striking into an ant-heap by Osgodby Coppice. This horse had a singular career, being bought as a three-year-old out of the station omnibus at Peterborough for forty pounds, and was intended for harness on Sir Gilbert's Cheshire estate. Coming to Belvoir as a second whipper-in's horse, he learnt his business ridden by Will Haynes, now huntsman to Lord Waterford's hounds. A lucky horse, with a wonderful constitution, he was never lame, sick, or sorry, a safe jumper, ridden by everybody or anybody, and kept out the longest hours as second horse. One day Sir Gilbert chose him, finding he was a good ride with the best of manners, gave him promotion, and very well the old horse always looked at the head of the procession.

Another grey that is perhaps just as well known, carrying Sir Gilbert Greenall, is the pony Bubbles, an absolutely perfect model of a weight-carrying cob, I4 hands 2 inches, sensible as a Christian, full of courage, able to gallop and twist like a polo pony. A favourite hack, he is always ridden by his owner at the Royal Agricultural Shows, when as Honorary Director he leads the Royal party round the Show grounds.

Mr. E. Wr. Griffith, field master to the Belvoir, is another who will be remembered riding a grey, a big 
weight-carrier of commanding presence, named Grey Friar. This horse when he belonged to Sir Gilbert Greenall carried Frank Freeman, the first whipper-in, and Mr. Griffith rode him eleven seasons, accomplishing just over three hundred days' hunting in that time-a good record for any hunter! Grey Friar is now succeeded by a long-tailed grey, named Gander, a Leicestershire type of hunter up to weight.

Amongst the eighty hunters stabled at Badminton we remember seeing in Igo5 two powerful weightcarrying greys, which were the favourite mounts for the Duke of Beaufort when hunting his hounds. Grey Skin, bought from Mr. Muntz, stood I7 hands 2 inches, was a model of power and symmetry, and Will Strap, an Irish horse, was quite the biggest hunter we have ever seen, standing I 8 hands.

Turning to personal experiences of twenty-one seasons riding with the Belvoir and Cottesmore, grey has been a lucky colour when replenishing a two-day-a-week stable. Seven of that colour have occupied the stalls of our stable at one time or another, showing no end of sport, and leaving pleasant memories behind them. The one horse of a lifetime was a grey, purchased as a four-year-old for twenty-four sovereigns out of an Irish drove at Corby fair. Coming into our possession at the halcyon period of a hunting career, when every fence is a friend, little Grey John, who stood $\mathrm{I}_{5}$ hands 2 inches, gave us many a long day's hunting and many a crashing fall. For fourteen seasons, from I888 to I902, he was the mainstay of the stable, hunted or driven by Mrs. Bradley, game as a pebble, with a constitution of iron, and a dash of Irish waywardness in his composition. During one particular season, when suffering from a rider's strain, 
so that to grip the saddle was an impossibility, we kept in touch with the chase by dismounting, driving John over the fence. A very sensible horse, he always stood still on the far side, until we climbed over and got on his back again. In one particularly good run across the line of grass that lies in the valley between Lenton and Ingoldsby we found ourselves

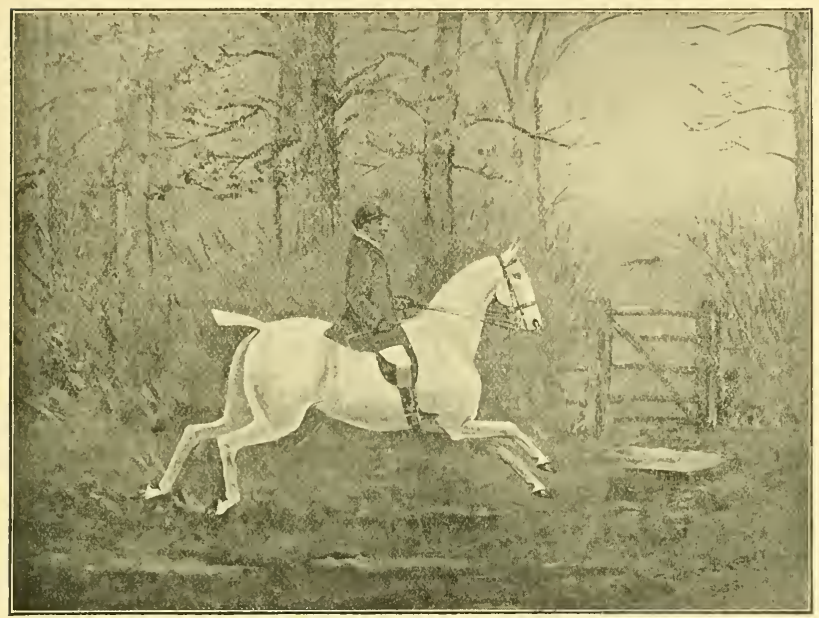

Sir Gilbert Greenall on Phantom.

cornered in a field, confronted by a very stiff high post and rails. Hounds were running in view hard on our left, and on the far side the fence a large section of the field were galloping up a lane, in the full enjoyment of a good hunt. Whilst considering what was best to do, and fearfully afraid of being left behind for the rest of the day, we were joined by Captain H. T. Timson, the present joint-master of the New Forest Stag-hounds, who was also riding a bob-tailed grey horse, the counterpart of our own. The hard-riding Captain was also on the partially 
disabled list from a similar injury to his leg, so that he at once dismounted, driving his horse together with mine over the formidable obstacle. The pair of greys rapped the timber all round, and with flying reins and stirrups landed into the lane amongst the galloping squadrons. "Catch my horse, please!" sang out Captain Timson. "I hope the fall has not hurt you?" was the anxious inquiry from sympathetic friends, who at once caught our horses, not realising how it had all happened. "We are not much hurt, thank you!" replied the Captain, as he remounted and galloped away in hot pursuit, well in it again, thanks to the successful strategy.

Grey, in fact, was an irresistible colour for us at one time of day, two being picked up for an old songaged horses that had been cast for harness work. One of these, a very game-looking sort, was working a tradesman's cart; he had no mouth and could jump anything; but at a gap he invariably landed on his head, falling into and out of a field on more than one occasion where a child's pony could have gone with safety. However, he conveyed us for one delightful season, jumping oftener than we intended (!), and was admired by so good a judge as Frank Gillard.

The other big weight-carrying horse, G.P.O. or Puffin, with musical propensities, was a noble-looking animal so long as he carried his flesh, and stood up for three seasons after being bought out of the shalves of a country mail-cart. He originally carried a master of hounds in the north, and had been a brilliant hunter in his day! In fact, now we come to think of it, all the seven greys that came into our possession were useful harness horses between timesa point not to be despised in a small stable, besides 
being a guarantee that legs and feet can stand the hard going.

It is a pair of grey horses that figure, on the most auspicious occasion in our lives, when plighting our troth at the altar with the lady of our choice. After embracing a large concourse of newly-acquired relations, and observing all the ordinances and ceremonies instituted by custom, a pair of grey horses, probably cast-off hunters, done up in white favours, appear on the scene to start the happy bridegroom with his blushing bride on their first journey together in life. Here again a little bit of superstition as well as sentiment creeps in, because the colour is supposed to frighten away the witches.

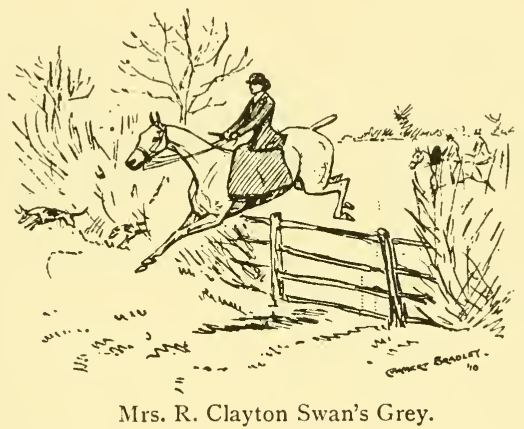




\section{CHAPTER VII}

\section{BLANKNEY REMINISCENCES OF SIX MASTERSHIPS}

Squire Henry Chaplin, founder of the Blankney hunt-A gathering out hunting of those connected with the history of the hunt-Sir Robert Filmer, M.F.H.-Lord Lonsdale and Blankney Villager, I884-Lord Henry Bentinck's hounds-Mr. Henry Chaplin's hunters when master of the Blankney-Major Arthur Tempest's mastership-Mr. "Natty" Cockburn's mastership-And the Earl of Londesborough-Winners at Peterborough, 1894-Blankney Ambrose, 1898-Harmston Hall-Mr. "Natty" Cockburn's hunters -George Shepherd-E. Boxhall-Some good days in 1903-4Mr. Edgar Lubbock, master-Some of his hunters-Some good days in 1906-Lord Charles Bentinck's mastership and advice to hunting people-Two good runs in 1908 with Lord Charles Bentinck and the Blankney hounds-Sir Robert Filmer, master, 1909The winning puppy of the entry, Vandal-Tom Isaacs, the new huntsman.

"The merry men of Lincolnshire were forward in the fray,

When Skipworth rode their Gay-lad, and Frist steered their Grey. ${ }^{1}$ Tom Oliver, and Vanguard had glory to their meed, And unrivalled for a season were Chandler and Proceed;

Salute and Pioneer amid the bull-finches did revel,

And Newport viewed the energy of Lincoln, steered by Bevill. Peter Simple, by four triumphs, earned the praise from every foe'He's an ugly one to look at, but a devil for to go!'"

-Old Lincolnshire Song.

THE Blankney hunt owes its existence to "Squire" Henry Chaplin, returned member for mid-Lincolnshire in 1868 , who established the pack over thirty years ago, holding the mastership from I 877 to I885. One of the best heavy-weights of his time across country, especially well mounted, the Squire of Blankney is known to the present generation as a great politician, "the last word on the grand manner of the mid-Victorian era," as the Prime Minister said, and a regular follower of the Leicestershire packs,

\section{Peter Simple.}


still a quantity to reckon with, when a knotty argument has to be settled or a fence jumped. On a certain day in January I907 when the Blankney hounds met at Coleby Hall, near Lincoln, the field included quite a gathering of those whose names are connecting-links in the history of the hunt, and for that reason was most interesting. The meet was at the residence of Major Arthur Tempest, late of the IIth Hussars, who succeeded Mr. Chaplin in the mastership, holding it from I88I to I895, a brilliant

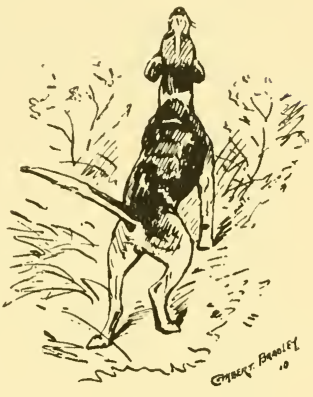
period of sport in the latter part of which Ben Capell came on the scene as huntsman. Major Tempest's fame for horsemanship will go down to posterity, riding as he did on four occasions in the Grand National Steeplechase, twice being second, the best performance being the Colonel's year, I87o. Both the reigning masters were out, Mr. Edgar Lubbock, who succeeded Mr. N. C. Cockburn in I904, being joined in I907 by Lord Charles Bentinck, who undertook the duties of huntsman and master until the spring of I9o9. The youthful Lord Raincliffe was riding a pony, and represented his father, the Earl of Londesborough, who held two years' joint-mastership with Mr. "Natty " Cockburn, who served the hunt well for nine seasons, and then went big-game shooting. Noticeable were Lady Castlereagh and Miss Florence Chaplin, daughters of the first master to the pack, on a visit to Blankney for a few days' hunting. Amongst others out was Sir Robert Filmer, hunting from Grantham, an officer in the Grenadier Guards, and owner of an estate in Kent, who suc- 
ceeded Lord Charles Bentinck in the mastership of the Blankney, at the end of season Igo8-9. Sir Robert Filmer was one of the foremost riders with the Leicestershire packs when hunting from Grantham, and in I904 won the Belvoir hunt redcoat race, riding his horse Blair, a grandson of Blair Athol. A representative following included Lady Charles Bentinck, the Duchess of Sutherland, Major J. H. Rennie, Mr. Ernest Chaplin, Captain J. Reeve, Captain Roger Tempest, Miss Tempest, Mr. W. Fane, Mr. and Mrs. E. Royds. Owing to the prevalence of fog, the greater part of the day was spent rousting up numerous foxes in Stapleford Wood, a famous covert with the best of grass rides.

Major Tempest's term of mastership had one short break, the Earl of Lonsdale coming to Blankney from the Woodland Pytchley, and the hounds he brought into the kennel made their mark in subsequent pedigrees. Especially distinguished was Lord Lonsdale's Villager ('84), a nice dog in his work, and on the flags, coming into the pedigree of Belvoir Vagabond ('99) and other notable sires.

The Blankney is a riding hunt, having the advantage of being within distance of Leicestershire, and a strong contingent of well-mounted farmers, the Saturday fixtures in the best country near the Vale by Wellingore, attracting good representative fields from two or three counties. An off-shoot of the old Burton country, the short history of the Blankney is linked with most historical associations and Lord Henry Bentinck's famous pack. Their blood is the foundation of the Blankney kennel, and many masters of hounds swear by the strains for work and excellence in the field to-day. Sir Reginald Graham, in a volume of hunting experiences, gives an interesting note of the famous pack 
in the sixties. "Who that ever saw the pack when in Lord Henry's hands, and hunted by Charley Hawtin, can forget how at the end of the longest day they would cast themselves one or two fields in front of their huntsman, and fling themselves at a gallop in a semi-circle till they recovered the line. ... As regards foxhound blood it was almost a

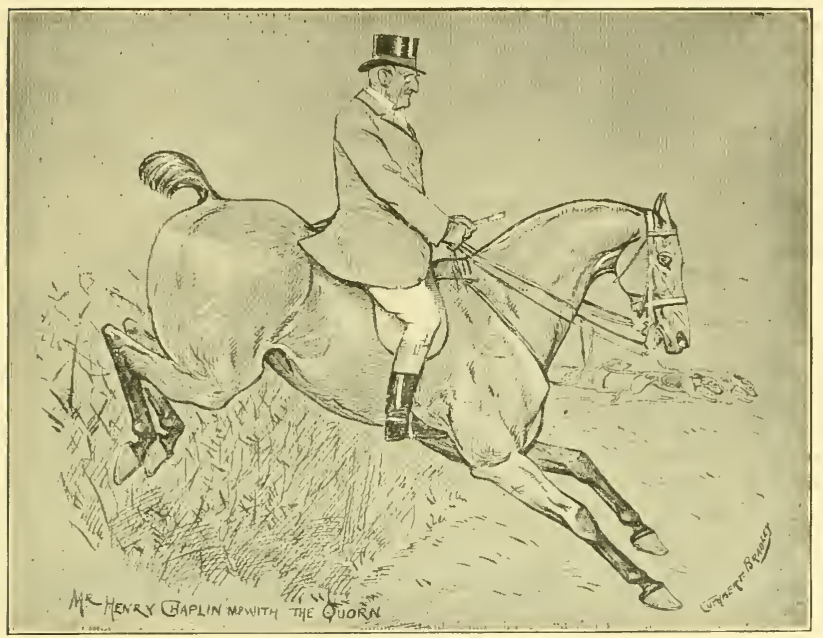

Mr. Henry Chaplin, M.P.

national calamity when such a famous pack was dispersed at the hammer. Let those who have the blood value it as priceless, for now it could not be obtained for love or money."

Yet it is said that Lord Henry Bentinck cared less for large bone than many masters, but was very particular with regard to work, and it is pretty certain that very few of his hounds would have been "looked at" in the ring at Peterborough to-day. Of Lord Henry Bentinck, Mr. J. Neville Fitt relates, 
in a volume of "Covert Side Sketches," that "No man ever mounted his men better, and in buying hunters, price never stopped him. . . . For a horse called Shropshire, he paid six hundred, and agreed to allow the former owner one hundred a year, so long as the horse carried him."

Mr. Henry Chaplin was another who had a stud of magnificent hunters when at Blankney, and the same authority just quoted continues: "It is needless to say that Mr. Chaplin himself has always been especially well mounted, as indeed was needful, as he is far from a light-weight, and where hounds go he goes, be the country what it may. He has, perhaps, never had a better horse than the grand chestnut Emperor the First, which I have seen him go well on, and no wonder, as he was at one time considered the best weight-carrier in England, and report says : Mr. Chaplin refused a thousand guineas for him. .. Snowstorm, who could win steeplechases and get hunters, besides carrying his master with hounds, has done good service in the country; and when Mr. Chaplin had him and Dalesman at Blankney, no man in England could show two finer hunter sires."

A successor to Major Tempest in I895 was found in Mr. "Natty" Cockburn, who, fresh from the Oxford University, where he captained the Polo, entered with zest and energy on the pleasures and responsibilities of mastership, to so sporting a community as the Blankney. Purchasing a stud of good-looking hunters, about thirty-five in number, of a blood-like stamp, he appointed the hunt in a style befitting Leicestershire. No expense was spared to ensure sport, and Mr. Cockburn held office until I904, the last two seasons assisted by Lord Londesborough in a joint-mastership. Of 
the hounds much might be said, the strength of the kennel being fifty-two couple for four days a week; first under Ben Capell's management, then under George Shepherd's, the pack reached a high standard as regards necks, shoulders, legs, and feet. At Peterborough in Major Tempest's mastership during I894, Ben Capell secured honours

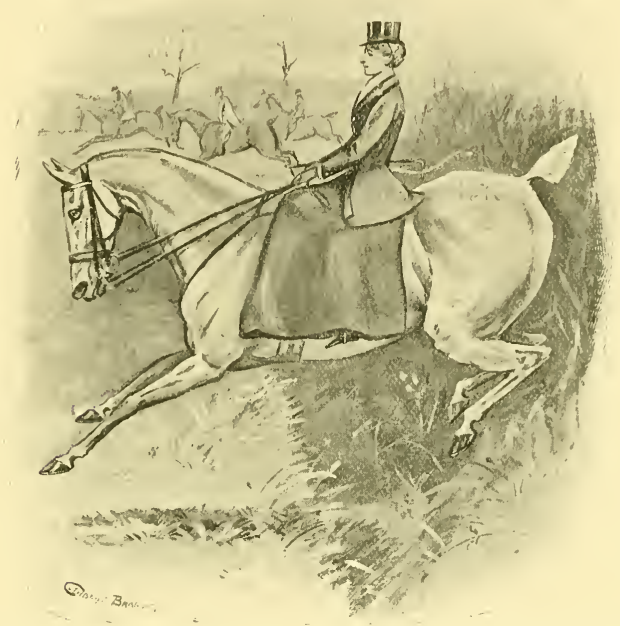

The Hon. Mrs. Lancelot Lowther, with the Quorn, on The Rake.

with two couple of dog-hounds, these being Garnet ('9o) by Belvoir Glancer, from Rarity by Lord Lonsdale's Villager; this hound being placed second to the Craven Vagabond for champion honours. Others of the winning quartette were Striver ('9I), by Belvoir Guardsman ('85), from Lord Lonsdale's Starlight; Foiler ('9I), by Belvoir Gambler ('74), from Fashion; Skillington ('93) by Brocklesby Smoker, from Meynell Forecast, 
all bred on the right lines for good looks and work.

The best dog-hound bred by Mr. Cockburn when master was Ambrose ('98) by Belvoir Falcon ('93), who was by Feudal ('87), who was by Syntax ('80), a son of Grafton Silence. The latter's name ought to have been enough to hang him, but he proved one of the finest sires the Grafton ever possessed, and was responsible for over a hundred couple of puppies in one season. Grafton Silence was by Statesman, a son of Senator, by Belvoir Senator ('62), "top dog" at Belvoir in his day. Senator ('62) was by SingerDestitute, and Singer was by Comus-Syren; by Mr. Drake's Duster ('44). Then to turn back to Belvoir Comely ('9I), the dam of Belvoir Falcon, she was a daughter of Shamrock, who was by Dashwood, by Founder, by Fallible, by Fitzwilliam Furrier. Of Fallible it was said by Frank Gillard, he was one of the three best hounds he ever saw in any part of a run. So that Blankney Ambrose ('98) possessed a combination of strains that are best in foxhound-breeding. His dam was Blankney Amethyst ('95) by Rufford Artist ('90), who went back to Atherstone Trimmer ('86), the dam of Amethyst being Rufford Gipsy ('93), by Lord Galway's Gordon ('90), by Belvoir Gordon ('86), by Belvoir Gambler ('84). The dam of Gipsy was Rufford Captive ('89), by Oakley Rhymer ('82). Ambrose developed into a sire of distinction, there being fourteen couple of his get in the Blankney kennel, season I904-5. He was also used by Yorkshire and northern hunts, his stock working out top of their entries.

A medium-sized dog, with first-rate shoulders and deep ribs, Ambrose possessed drive, speed, stoutness, and quality, carrying his bone well down. Quite 
one of the right type, he was just the hound to suit the requirements of the Blankney country, flying his fences in chase, and a great worker in every part of a run, qualities which he transmitted to his stock. Nearly all the sires of the Blankney entries about this period were Belvoir bred or once removed from that kennel, and included Belvoir Drayman, Vagabond, Game-boy, Stormer, Handel, and Hymen. Other sires who did the pack good were the Duke

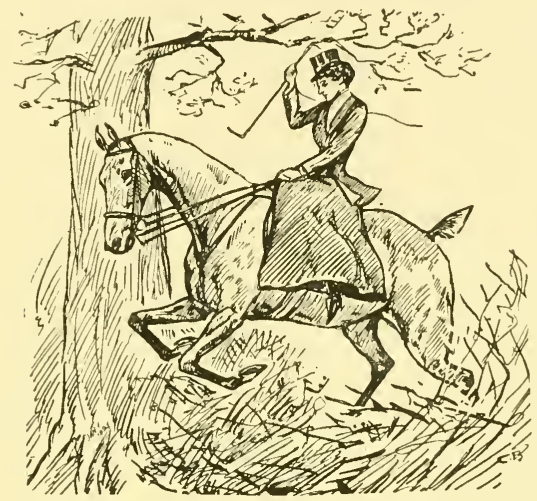

Grey John (1888-1902).

of Beaufort's Darter, full of Bentinck blood, which Mr. Austin Mackenzie so skilfully blended with the Belvoir. In the field they presented a sorty appearance with distinguishing Belvoir colouring, a handy pack hunting beautifully for George Shepherd, who showed excellent sport and killed his foxes.

A most attractive meet is Harmston Hall, Mr. N. C. Cockburn's picturesque residence four miles south of Lincoln, on the high ridge of tableland, commanding a magnificent view across the vale looking towards Newark. One of the master's best mounts was Grey Skin, a snaffle-bridled grey, which 
carried him at the top of many a good gallop, for he was a keen horse and very fast. In close attendance was generally to be seen his great friend Mr. Frank Oates of North Clifton Hall, who also rode a favourite grey horse, Grey Friar, bought from the Rev. F. M. P. Sheriffe; and when Mr. Cockburn gave up the mastership, this horse was sold to Mr. Edgar Lubbock, his late owner retiring from hunting. George Shepherd was very well mounted, and amongst his best horses, Morley, a dark chestnut up to fifteen stone, carried him three seasons every Saturday across the big grass country in the vale. Another favourite was Bobby, by the Bobby, a good-looking dark-brown horse with a white face, standing on short legs and active as a cat, Shepherd could get anywhere with him in the big drain country. Tommy Giles, with his quaint white markings, comes into the story of many a good hunt, for he was a little big horse, hard as iron. A better-looking horse than the bay Victor it would be impossible to wish for, possessing as he did substance and quality. As a stud they were a very nice level lot of horses to look through, with good backs and shoulders, nearly all of them short-tailed hunters with their manes off. The Blankney country requires a bold horse that can gallop, use his head as well as his hocks, for the ditches are wide, the fences strong, and very often the going is holding. The first whipper-in, E. Boxhall, was also well mounted, and a capital lieutenant for the huntsman, their united efforts crowning many a good gallop with blood. When Mr. Cockburn gave up the mastership, Boxhall went as kennel huntsman to the West Kent.

Referring to the diary of I903-4, the last season of Mr. N. C. Cockburn and Lord Londesborough's mastership, we find many good days' sport recorded. 
On Ist February, after the meeting at Beethorpe, where Captain Oates entertained the field, hounds scored what was considered the fastest gallop seen for many seasons. Finding an outlier near to Spalford Rabbit Hills, they raced him towards Collingham, past Scars to Swinderby, where they killed. Again on the IIth after meeting at Welbourn Windmill, hounds brought off a great hunt of

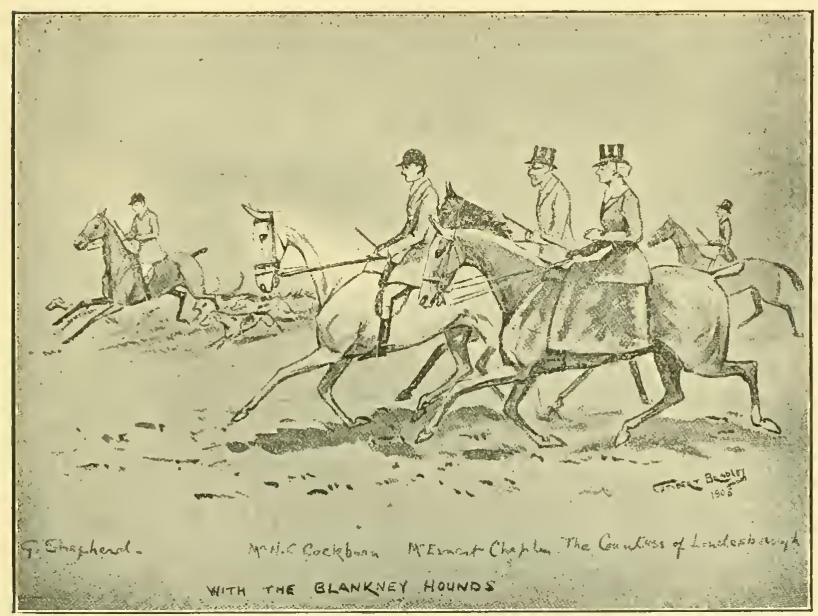

Mr. N. C. Cockburn, M.F.H.

one hour and forty-five minutes right into the Belvoir country, finishing at Willoughby Hall, the residence of Mr. Cyril Greenall.

On the 27th the fixture was Wellingore Hall, and though there were several slight falls of snow, it was not sufficient to stop hunting. In the afternoon from Coleby Gorse they ran a fox back by Somerton Castle, along the bank of the river Brant, the finish in deep water resembling an otter hunt. 
On r2th March the joint-masters were both out at Nocton, when sharp frost over-night was succeeded by thick fog. The afternoon hunt was started from Stockdove Holt, and going away at once into the Fens, they ran for an hour and a half, making a good finish by rolling their fox over in the open. The big drains caused lots of grief, for more than one wet jacket was in evidence, hounds having only a select field in attendance, the majority preferring to view the run from the hillside.

One of the last days of the season was in Stapleford forest, where Shepherd had thirty-two couple of hounds in the field. Those out included Lord and Lady Londesborough, Mr. N. C. Cockburn, and the master-elect, Mr. Edgar Lubbock. Scent lay well, and after a tremendous rattling in covert, every hound throwing his tongue, a brace of masks adorned the whipper's-in saddle before two o'clock.

Mr. Edgar Lubbock's accession to the mastership of the Blankney, with George Shepherd retained as huntsman, was immensely popular with the country-side, for there was no one better known or so beloved in the Belvoir hunt. Hunting more frequently on the Sleaford side of the country, Mr. Lubbock was privileged to hold fixtures about once a fortnight in Belvoir domains, much to the delight of his many friends. Always keen for a ride, the new master infused his following with the same ardour to be with the flying pack! The average of sport was good as ever, and amongst the new hunt horses were many bang-tailed thoroughbreds that looked like winning a chase. Bachelor's Pride, own brother to Bachelor's Button, was one of these, carrying the first whipper-in, Will Weston, afterwards passing into the possession of Captain George Paynter, for whom he won chases. Amongst others 
was the Beau, winner of the Private Sweepstake at Croxton Park, afterwards passing into the possession of Mr. Harry Armour of Linlithgow. and Stirlingshire Hunt point-to-point fame. Port Said, a dark-brown thoroughbred horse, took a bit of riding, but could both gallop and jump when in the mood to do so. Perhaps the horse that showed the master most sport was The Cat, a strong chestnut, carrying him six seasons without a fall; quite a record for Mr. Lubbock, who enjoyed jumping a great many fences, and took his fair share of tumbles!

Looking over the story of many enjoyable days we saw with Mr. Lubbock, the following occurred in March I905. The Blankney met by invitation at Rippingale, a Belvoir fixture, and in the absence of Shepherd the hounds were hunted by Will Weston. Getting clear of the large tract of woodland Dunsby, Kirkby, and Bulby, a fox was persuaded to face the open from Aslackby Wood, shaping a course across a charming line of grass country from Keisby, away over the Lenton Brook. Unfortunately scent was very weak, and more pace was necessary to make it a really good hunt. The day was made memorable by the afternoon gallop from Folkingham Little Gorse, hounds getting away close at the brush of their fox, racing over the grass below Birthorpe, twisting left-handed up to Stow Green. Never checking, they raced up to Spanby, and pulled him down a field away from Newton Gorse, after going twenty minutes at top pace. Only those who got away with a good start saw the finish, and were a small band, including the master, riding The Cat; Mrs. R. J. Ellison, well carried by a grey; Miss A. Reid, Captain H. Steeds, Mr. F. H. Schwind, Mr. C. de Paravicini, Mr. J. Tomlinson, Mr. J. Rudkin, 
and Will Weston, who took a fall, but was there in time to handle the fox.

Another good day was after meeting at Brant Broughton, where the field included the master General Sir Mildmay Willson, C.B., Sir George Whichcote, Sir Robert Filmer, Major Tempest, Major J. H. Rennie, Mr. and Mrs. R. Clayton Swan, the Hon. Gertrude Walsh, Captain J. S. Reeve, Mr. E. Royds, Mr. C. de Paravicini, Captain J. Thorpe, Mr. Cyril Greenall, Mr. E. A. Smith, Mr. H. Jackson, Mr. C. Hartley, Mr. Cecil Wray, Mr. J. Mountain, Mr. Burroughs, Mr. H. Morley, Mr. A. E. Tomlinson, Mr. W. B. Burt, Mr. Wigram, Rev. F. M. P. Sheriffe.

Finding quickly near the meet, they ran in the direction of Stubton, coming round by Stragglethorpe and Leadenham into Waterloo Gorse, where a good hunt of thirty minutes ended. Finding again in Brant Broughton top covert they ran by Beckingham, crossing the river Witham into Stapleford Wood, making quite a good day's sport and a hard one for horses.

In January Igo6 the Blankney with many Belvoir followers assembled at Aswarby Park, where Sir George Whichcote entertained a large field, which included the master General Sir Mildmay and Miss Laura Willson, Miss Sylvia Amcotts, Mr. and Mrs. R. Clayton Swan, the Hon. Gertrude Walsh, Mrs. Montague Thorold, Mrs. G. Schwind, Mrs. T. W. Stanton, the Miss Reids, Captain J. S. Reeve, Mr. and Mrs. Norton, Captain and Mrs. Pritchard, Mr. A. E. and Miss Jessopp, Mr. E. Chaplin, Mr. W. Fane, Major J. H. Rennie, Mr. Cyril Greenall, Major J. A. Cole, Mr. and Mrs. E. Royds, Mr. Cherry, the Rev. F. M. P. Sheriffe. Aswarby Park is a stronghold for foxes, as many as 
three different hunts, the Belvoir, Blankney, and the Marquis of Exeter's meeting there in the course of ten days. Hitting off a line by Caswell's Plantation, the lady pack rattled along in brilliant fashion for fifty minutes without touching a covert, running past Threekingham, nearly to Folkingham, over the brook up to Walcott, away past Newton, nearly to the Nightingale Gorse on the Bridge End Road, where they suddenly threw up, after a very trying gallop for horses in the deep going.

Reviving the memories of a famous ancestor, Lord Charles Bentinck held the mastership of the Blankney for three seasons, hunting hounds himself. A finished horseman, his name recalls the most exciting period of the inter-regimental polo tournaments, when the 9th Lancers, the roth and I3th Hussars fought hard for the championship on Hurlingham's fair fields. The following suggestions were made by Lord Charles Bentinck to hunting men, set forth in an article by Mr. Arthur W. Coaten, which appeared in the Badminton Magazine, October Igo8:--

"Subscribe more, and don't depend so often on finding a rich man willing to take the mastership. It is often a hard and thankless task, and people ought not to expect to get a good servant for a bad wage.

"Work harder in the country among the farmers and small holders especially. Educate in fact.

"Walk puppies. Hunting men should be ashamed to let poor people who cannot afford to hunt, and often never see a hound, do this for them out of their great sporting hearts.

"Grumble less. It is not much encouragement to a master to spend his money, time, and health trying to provide sport for people whose most 
cherished privilege seems to be to grumble at everything he does. My experience is that those most ignorant about hunting are the worst

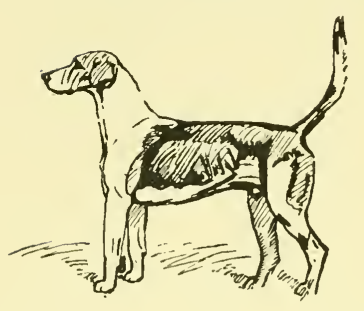

grumblers. Therefore the remedy would seem to be to educate themselves."

Just before Christmas, December Igo8, we have memories of two good days' sport seen with Lord Charles Bentinck and the Blankney hounds. The first

was on the I7th, after meeting at Ewerby on a wretchedly wet morning, when a start was made from Sills Gorse, hounds being served by a marvellous scent, which enabled them to run hard for ninety minutes, scoring a nine-mile point right into the Belvoir country. The line was by Asgarby, Kirkby Mount, Moneys Gorse, through Aswarby Thorns and Osbournby Hill Top to Newton Wood, with scarcely anything in the nature of a check from start to finish. A kill was all that was wanted to crown this good gallop.

On Christmas Eve Igo8 a large field assembled in Sleaford market-place to meet the Blankney, Lord Charles Bentinck being in command, and amongst those riding were Lady Charles Bentinck, Lord Henry Bentinck, Lady Irene Denison, Lord Raincliffe, Lord Burghess, General Sir Mildmay Willson, Mr. Arthur and the Misses Willson, Major General J. F. Brocklehurst; Sir Robert Filmer, the Countess of Clonmell, Captain J. S. Reeve, Mr. A. L. and Miss Jessopp, Mr. Amcotts, Captain R. Tempest, Major J. A. Cole, the Misses Morton, Miss F. Smith, Mr. Cyril Greenall, Mr. E. A. Smith, Mr. and Mrs. Norton, Mr. H. Godson, Dr. D. G. Thomson, Mr. F. Ward, Mr. and Mrs. E. S. Tomlinson, 
Mr. C. Smith, Mr. H. Morley, Mr. Earl, Mr. G. Pilkington, Mr. B. Caswell, Mr. B. Colson, Mr. J. Tomlinson, and several others.

Sleaford Wood did not supply a fox, but an outlier was set going in the Ruskington district, running by Roxholme and Cranwell. After paying a hasty visit to Fumards Pits he took a ring out to Brauncewell Grange; Lord Charles Bentinck, who was riding a bang-tail black horse, handled the pack in masterly fashion, and lifting them to a halloa, had his fox well beaten before reaching Dunsby Gorse, where they killed after a good hunt of thirty minutes. "Who-whoop!" screamed Lord Charles as he carried the fox triumphantly out of cover; "who-whoop!" every hound throwing their tongue to swell the savage chorus!

Sir Robert Filmer inaugurated his mastership to the Blankney hunt with the puppy show and luncheon during August Igog; the judges for the occasion being his uncle Sir Herbert Langham, a famous ex-master of the Pytchley, Ben Capell, huntsman to the Belvoir, and J. Smith, huntsman to the Brocklesby. The "top dog" of the entry proved to be Vandal, by Cottesmore Vandal ('o3), by Belvoir Vagabond ('99), who strained back to Lord Lonsdale's Villager ('84), one of the best hounds a.t Blankney in his day. The dam of Vandal is Furious, full of old Blankney blood; the

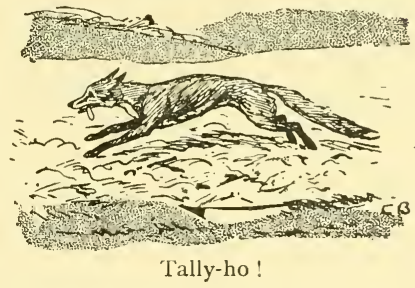
success of the young hound being a triumph in breeding and selection on the part of the retired master, Lord Charles Bentinck.

For the post of huntsman Sir Robert Filmer 
secured the services of young Tom Isaac, son of Charles Isaac, so many years huntsman to Mr. Fernie, and nephew to John Isaac, huntsman to the Pytchley, both of whom in their day whipped-in to Sir Herbert Langham, when Will Goodall was huntsman to the Pytchley. The Blankney under the new mastership enjoyed during Igog-Io one of the best season's sport on record. 


\section{CHAPTER VIII}

\section{A HUNT WITH MR. CHARLES MCNEILL AND THE NORTH COTSWOLD HOUNDS}

The North Cotswold the Eden of fox-hunting-Mr. Charles McNeill, the disciple of Tom Firr-Tom Firr's horn-The composition of the North Cotswold pack-Belvoir-bred bitches-Prices made by Belvoir-bred packs - The celebrities of the kennel-The advantages of well-bred hounds-A Leicestershire element in the Cotswold hill country - The hunt horses-Following Tom Firr across country - Broadway and the kennels-The pick of the stable-A hunt in the hill district-Dan Reid-A fox found up in cloud-land-A burst over the stone wall country and a kill-A fox dies game in front of the pack.

"I remember the lowering wintry morn, And the mist on the Cotswold hills,

Where I once heard the blast of the huntsman's horn, Not far from the seven rills.

I remember how merry a start we got

When the red fox broke from the gorse;

In a country so deep, with a scent so hot, That the hound could outpace the horse."

-Adam Lindsay Gordon.

THERE are few more picturesque hunting districts than the country around the Cotswold Hills in the fair county of Worcestershire. This Eden of foxhunting is a much-sought-after possession, wild and rugged, with variety of scene on hill and dale, pasture and woodland. In the hill districts of the North Cotswold country walls are the only obstacles, but in the Evesham vale on the grass, are flying fences with good pasture ground equal to anything in the shires.

It has often been said that farmers are the II 3 
backbone of fox-hunting, and these Worcestershire sportsmen bred and born are a community whose fame for staunchness to fox-hunting is known far and wide. The majority of them or their sons ride to hounds, and wire is practically unknown in their country, whilst foxes are preserved as they ought to be-the best of good feeling prevailing between sport and agriculture. Many countries may go a-begging for a master, but

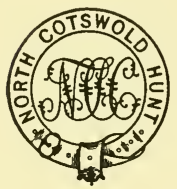
not so the North Cotswold, whose Hunt Committee have on occasion had over twenty applicants for the coveted post.

Our first sight of the North Cotswold was in I9o6 when staying with Mr. Charles McNeill, who held the mastership for five seasons, IgoI-6, a period of brilliant sport which will long be remembered in the country. Mr. McNeill learnt his hunting from Tom Firr, residing for several years in Quorn village at a period when he was a most successful breeder of fox-terriers, securing many championships in the show ring. Reviving memories of those happy days in I896 and after, Mr. McNeill said, "I was continually in kennel studying his methods, and had a pack of beagles of my own at Quorn, with which Tom Firr used to come and run, occasionally treating us to one of his silvery view halloas. At that time he was captain of the Quorn Cricket Club, but had to give it up, as his knee was always slipping out of joint. One of nature's gentlemen, he was a very reserved man, but in the long rides home from hunting used to become more communicative than at other times, and would talk over the doings of the day, arguing out what he considered his faulty casts, but always having a reason for every one he made. When he was forced to relinquish the post of hunts- 


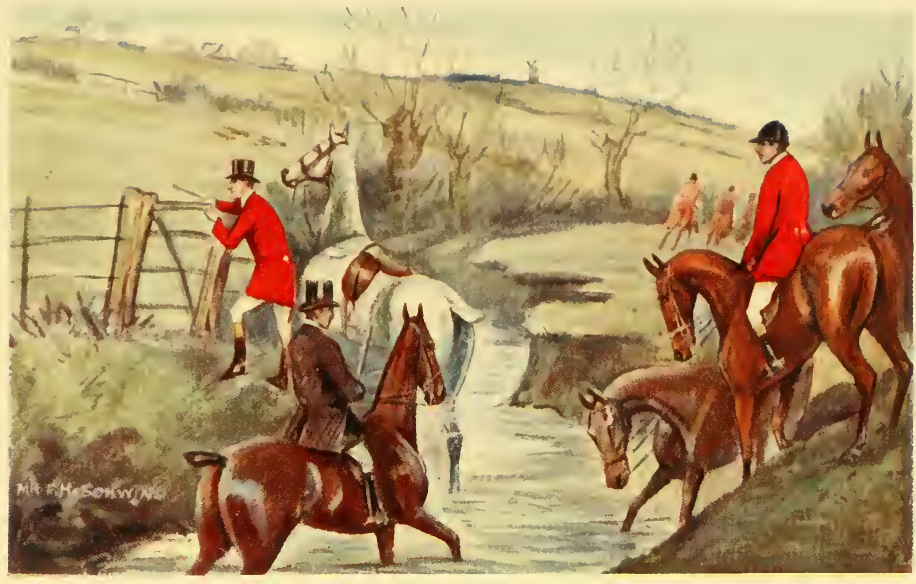

I:()LINGHAN BR()I:

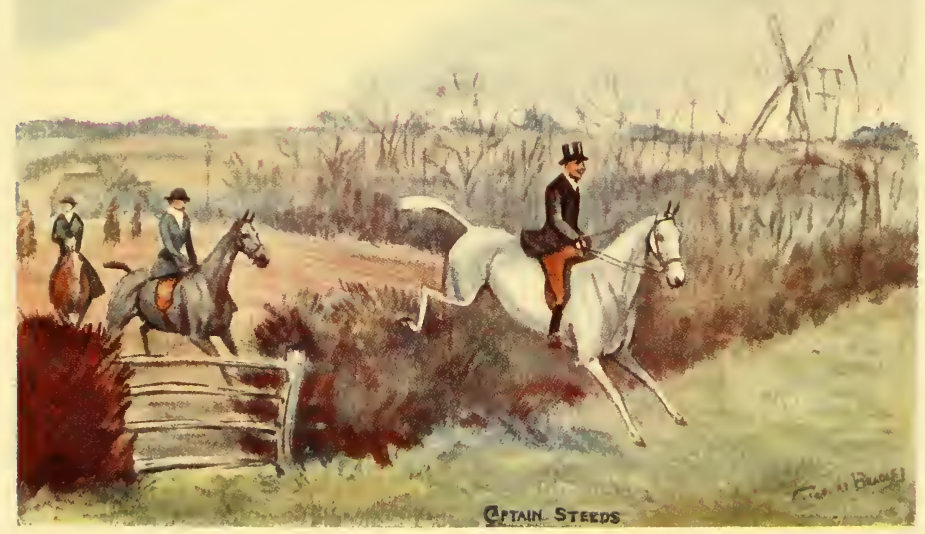



man to the Quorn, he sent me one of his old horns and had it engraved as follows :-

\section{" From Tom Firr}

In memory of many good gallops since 1886.'

And he said in his letter he hoped some day it would blow hounds away on a fox for me. At that time I had no idea of taking hounds."

When Mr. Charles McNeill undertook the mastership of the North Cotswold in Igor, he purchased a mixed pack from the retiring master, Captain Cyril

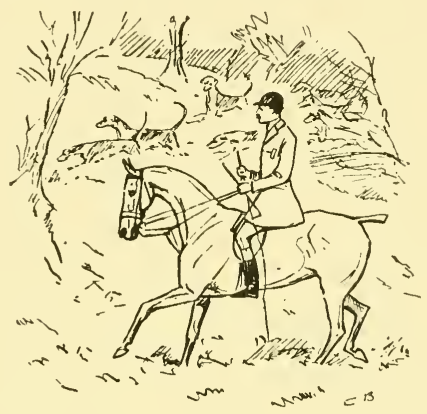

Mr. Charles McNeill, M.F.H.

Stacey, and retained only the bitches, the dogs being sold to Lord Portman. Bearing in mind that a stock of good "typy" bitches is more than half the way to success, drafts were bought from the Belvoir, Atherstone, Mr. Fernie's, and the Duke of Beaufort's, all being mated with Belvoir sires, possessing one or two lines of the same blood. The improvement came chiefly with the Atherstone purchases, which were three parts Belvoir, all the matrons, amounting to fifteen couple a season, being sent to the Belvoir sires. Substance with quality was the chief point aimed at, and therefore few whelps were brought up by one dam, and none of the dog puppies reared. 
The formation of a pack of hounds of the highest class has been the life ambition of many a famous sportsman of the past, and Mr. McNeill in six seasons built up one of great excellence. The kennel presented a very level appearance-brimful of quality and matching in colour-the type throughout being Belvoir; the big bitches, measuring rather over twenty-three inches, were remarkable for muscular backs, strong quarters, and well-sprung ribs. In chase they were deep-noted as dog-hounds, and with nothing older than five-season hunters running with the pack presented the zenith of vigour - a determined lot of ladies who meant catching their fox at the end of a gallop. The season we hunted with them they killed forty brace of wild hill-foxes up to the end of February, though the district is poor scenting, and the country only two days a week, though three is sometimes managed. In breeding Mr. McNeill went close with happy results, having gained experience with show fox-terriers, his favourite blood in hound breeding being Belvoir Dexter ('95) and Belvoir Vagabond ('99), judiciously crossed in and out. Such was the pack that showed much excellent sport to the followers of the North Cotswold, and won many honours on the flags at Peterborough. When Mr. McNeill retired in I 906 from office as master and huntsman, the pack of forty-two couple of bitches was purchased by the newly appointed master, Sir John Hume Campbell, for $£ 3600$, a sum which expert opinion said would have been exceeded if the pack had gone into the open market. We may call to mind the success of other Belvoir-bred packs in late years, viz., the Woodland Pytchley, sold by Mr. Austin Mackenzie, the dogs making $£ 2000$, the bitches $£ 3000$; the Morpeth, sold by Mr. R. Clayton Swan, made $£ 3000 ;$ and the Atherstone, sold by 
Mr. Gerald Hardy when he moved on to the Meynell mastership, went for another $£ 3000$. Our pleasurable mission to the North Cotswold kennel was to paint the picture of this beautiful bitch pack, subscribed for and presented by the farmers to Mr. McNeill on his retirement.

Probably the most remarkable family in the kennel was a litter of four couple of sisters in I905, by Belvoir Handel ('99) from Atherstone Pitiful ('99). These included a couple who afterwards won champion honours at the Peterborough and Reigate hound shows, the names of the full litter being Piteous, Pilgrim, Pin-tail, Pittance, Pie-crust, Piety, Pillage, and Pitiless. The most distinguished of these was Pilgrim, a massive bitch standing on beautiful legs and feet, showing the gayest Belvoir colouring, who latterly threw a litter of whelps to Brocklesby Armlet, and won champion honours at Peterborough for Sir John Hume Campbell in Igo8. If we had been asked to select seven couple at the end of season I905-6, we should have taken Pilgrim, Piteous, Pin-tail, Dairymaid, Negative, Necklace, Gadfly, Dazzle, Gratitude, Trifle, Pittance, Havoc, Daring, and Blissful, all of whom come into the picture. But there were many more so close up, that another opinion might have reversed the decision all through. No wonder that such a sportloving community were delighted when they knew the pack was to remain in the country. It was surprising to all how well the hounds' legs and feet stood the hard going and the strain of jumping stone walls, proving the worth of good bone and breeding, which, like first-class machinery, can go at the highest pressure and last. Mr. McNeill told us that hounds light of bone below the knee or long in their feet, were of no use to wear in such a country. Still it 
is marvellous to think that half the pack did not get their toes down before Christmas, much more that they could show with the best on the flags at Peterborough in the summer. Tom Firr used to stay with the master at Broadway, and many a useful hint and valuable suggestion did he make at a time when the kennel was rising into the front rank.

A certain air of Leicestershire was imported by Mr. McNeill into the North Cotswold country, the hunt servants being well turned out and beautifully mounted. The new departure and faster era of sport was thoroughly appreciated, and strangers sojourned in the land, so that in the course of a season or two the following and subscriptions considerably increased, every house and stable in the district having its hunting occupants. Yet it is but a little country and far removed from Leicestershire, its extent being fourteen miles long and eight miles wide, or rather less than that at its apex and base. With the large community of farmers this brilliant era of sport came as a revelation, and sad was the parting when their inspiriting leader laid down the horn, which once belonged to Tom Firr.

As might be expected, Mr. McNeill favoured a very nice stamp of blood-like horse on short legs, something that could gallop and jump, and stay the very best over the rough stony hills, or stride across the Evesham vale. Here again the best-bred ones seemed capable of doing the most work in a rough country, with less damage to joints and tendons than is the case with underbred horses. The muscle that met the eye, on backs and quarters, showed that they were horses not kept to look at, for nothing but work could put it there! Like the hounds, the horses had youth on their side, changes taking 
place every second or third season to make room for young ones coming on. The North Cotswold hunt horses when sold made the extraordinary average of $£ 253$, two that had carried the master hunting hounds and won chases, making 500 and 400 guineas. Reviving Leicestershire memories and impressions of the ideal in horsemanship, Mr. McNeill said, "No finer horseman than Tom Firr ever crossed Leicestershire ; apparently only cantering when others were galloping, and yet always in front, arriving at the best place to jump as if by instinct, he slid over and was gone! Many a fall and many a crumpler have I seen, and had myself, from thinking there was nothing to jump, when it turned out to be a wide bottom, which he had jumped in safety, without any apparent effort."

Those who have never yet seen Broadway, the Worcestershire village in which the North Cotswold kennels are placed, have a pleasure in store. It is an old-world place, with picturesque houses, whose stone roofs are hung all over with jessamine, honeysuckle, and mountain-climbers. There is a wide street with a village green and a fine hotel, the resort of American tourists, who know Broadway and its charms! The kennels are exactly opposite, nestling under the Cotswold Hills, with a grim old weather-worn tower on the summit, grinning defiance down on you. The yard is most compact, and there is the huntsman's house with walking paddocks, meal-room, and feeder's house, making as pretty a picture as any sportsman might wish to see.

The row of stabling for twenty horses is close by, under the charge of Allan, the stud-groom, who came from Sir Bache Cunard, when he gave up the Leicestershire country, now known as Mr. Fernie's. The occupants of the boxes were as interesting as 
the hounds to look through, a rare lot of performers, many of whom we saw in the field. The stencilled fox on the sanded floor, thoughtfully put there by Allan to catch the artistic eye, called forth a view halloa from the master, who forthwith started a recitation of Whyte-Melville's stirring verses, until the stamping and snorting of the horses was a gentle reminder that a little of that sort of thing goes a long way! The most valuable horse we saw on that occasion was a six-year-old named Grey Tail, standing I6 hands and well let down. He looked the model hunter up to weight, showing beautiful quality, with faultless shoulders, long and well set, ribs sprung to a nicety, backed up by great quarters, that seemed to have jumping power written all over them. We noticed that he went in the shortest of short-cheek bridles, and his manners with hounds were perfect. A bold resolute horse, with legs of iron, he could slip over a country in the most finished style, and was good-looking enough for the show ring. When the stud was dispersed at the end of a very hard season's hunting, Grey Tail made 295 guineas.

The next horse was Bertie, up to more weight, and ridden a season by Sir Albert Nuntz. Mr. McNeill, who hunted hounds on this horse, thought he could jump his own height, for he had such a wonderful spring, being a light-hearted goer. His hunting record was that he did more days than any other in the Broadway stable, excepting the Slave, a chestnut ridden by Dan Reid, the kennel huntsman. Such a good-looking horse as Bertie, on the best of legs, was sure to arouse spirited bidding, and he found a new owner at 230 guineas. Romeo was another of the stud with a great character, not prepossessing when seen in the stables, standing idly 
with Roman nose and ugly hocks. Once outside his box, he could hardly be recognised as the same horse we had been looking at a few minutes previously. Up to I3 stone 7 lbs., with four grand legs, long sloping shoulders, and head beautifully put on, he swung past at a three-quarter gallop, looking for all the world like a point-to-point horse, or even something better. The son of Inferno, by Robert the

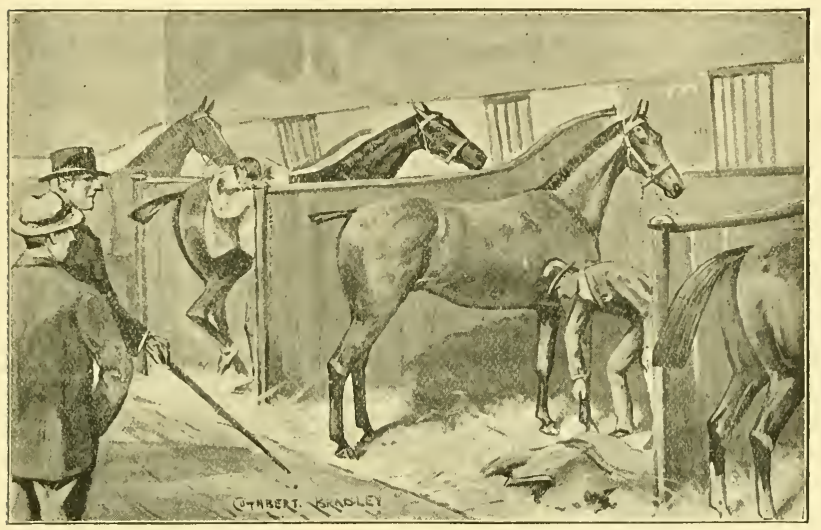

The Pick of the Stud.

Devil, Romeo was a great horse across country, and went for I5o guineas, after carrying Jack Scott, the first whipper-in. When we stopped at Master Bill's box and noted Mr. McNeill's expression, we knew we were looking at one of the master's favourites, but still he did not seem inclined to recommend him! "Jump? Oh yes, he can jump anything, has never put me down, and has never refused; but_-" "But what ?" we asked. "Well, he is sharp, very sharp," he said. "I rode him in a point-to-point a fortnight ago, and he fairly took charge of me for three miles. But for all that he is a rare sort, barely I6 hands, 
but looks like carrying a house, and galloping all day with it." His joints were somewhat big, and he went below his value at Ioo sovereigns. When we get on the " horse topic," the subject fairly gets away with us, for each horse called forth some reminiscence of a good day's sport, and there was the good grey pony hunted by Mr. McNeill's son when at home for the Christmas holidays, such a

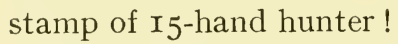

Our first sight of the North Cotswold in the field was at a meet on a village green in the hill district, when we were mounted for the occasion by Mr. McNeill. As the master rode up in the middle of a pack of seventeen and a half couple of bitches, there was a. cheery word all round, and that note of expectancy which precludes an enjoyable day's sport. The primrose-yellow collar is the distinguishing feature of the hunt uniform, and the coronet on the hunt button, a sole lingering connection of a former mastership under Lord Fitzhardinge. Dan Reid, the kennel huntsman, with a dash of Irish in his composition, looked quite classical riding a thoroughbred long-tailed black horse, and is one who has made many friends all through a life devoted to the service of the chase. For the first draw we commenced hill-climbing to the larch plantations, somewhere up in the clouds. It was a congratulation to find our mount was used to the country, with its steep ascents and surface of loose stones. These hills require a considerable amount of stopping before a day's hunting, otherwise a pack would be always running to ground; but Mr. McNeill's just doubled the average of foxes killed in a season, bringing it up to forty-three brace, though formerly it never reached twenty-five brace.

From the hill-top, probably a thousand or more 
feet above sea-level, to judge by the strength of the gale that was blowing, we had a glorious view of a far-stretching panorama of country in the vale beneath. Though the country is not a good scenting one, except when there is a bite of east in the wind, the bitches quickly roused their fox in the larch plantations on the hill slopes, their deep sonorous music lending enchantment to a scene of diversified loveliness. A second or two later, old Dan Reid was heard piping a fox away on a silver whistle, for there were no confusing halloas. Up came the master, flicking over the stone wall out of covert, and quick as lightning inspired hounds and followers with the urgency of the matter. Keeping their fox travelling up wind, they worked him down into the vale and a good riding country, taking a point for the Croome country on the opposite hill-side. It was a ride full of new experiences, to say nothing of some anxiety, giving us, alas, but a distant view of the master and his smart bitches flying over the stone walls which surround the seventy-acre pastures. A rain-cloud blotted out the view at the finish, enveloping the hillside in a dense wall of fog, robbing the pack at a critical moment of well-earned blood.

Talking of runs brings up a wealth of reminiscences, for it is a district in which the keenest interest is taken in the doings of hounds by the non-hunting fraternity, who are sportsmen to the very core. On a memorable occasion, after finding a good fox near Wyatt's Spinney, the bitches in the full enjoyment of a burning scent drove him along over the stonewall country at such a pace that he was forced to fly up wind. It was a regular Belvoir burst of twenty minutes, a fox going straight for his life, losing no time over the walls, and running up the middle of each field in a desperate effort to gain 
on his pursuers. Mr. McNeill viewed him nearly the whole of the journey, seeing him miss his footing at the last stone wall and fall back. Though the mistake only made a matter of a second or two, it sealed the doom of a gallant fox; for Housemaid dashed out with the lead, and, catching him by the brush as he topped the wall the second time, herself went over with the impetus, knocked out on the far side. An electrifying cheer from the master put a finish to the fastest burst of the season, when they killed under the wall near Springhill.

"Whoo-whoop! they have him-they're round him! how

They worry and tear when he's down!

'Twas a stout hill-fox when they found him, now

"Tis a hundred tatters of brown!"

Another good gallop, from a thruster's point of view as well as the huntsman's, was from Gallipot Gorse in the Vale. An old customer, who had led the pack on several occasions and saved his brush by getting to ground, was not so fortunate on this day. Running well by Toddington without touching a covert, they passed Worrington village and crossed the new railway below Laverton. It was evident that the pilot meant the earths on the hillside in Burill Wood, but two fields from that point the bitches suddenly viewed him. Up went their hackles, and, giving utterance to that cry of delight which proclaims the death-knell, their language seemed to convey its meaning to the hunted one. A curious incident occurred at the finish, which was witnessed by several members of the hunt. In the last grass field, when this gallant fox realised that he was beaten, he stopped and, turning round, met the pack. With gleaming ivories he died facing the foe, his teeth meeting in a death grip directly the 
WITH THE NORTH COTSWOLD HOUNDS I25 leading hound seized him. The master confessed afterwards that "It was the first time in his life, he was sorry that the fox had not just managed to beat them at the finish!"

A year or so later, when Mr. Charles McNeill went as master to the Grafton Hunt, his farmer friends of the old North Cotswold country made him a further presentation of a silver hunting-horn.

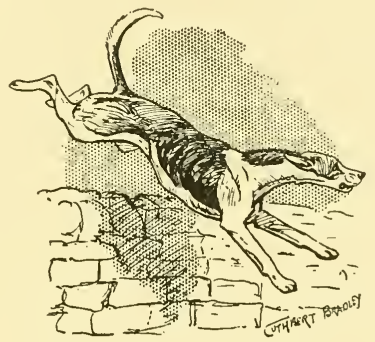

The Cotswold stone walls. 


\section{CHAPTER IX}

\section{TWO BELVOIR AND QUORN JOINT RUNS I 884 AND I9O8}

\section{PART I}

Saturday the great hunting day in Leicestershire-The best source of information-Belvoir and Quorn run of 1878 from Frank Gillard's diary-Belvoir and Quorn run of 1867 from Mr. John Welby's diary-The trophy of the great Belvoir Quorn gallop-Frank Gillard's letters descriptive of hunting-Admirers of Belvoir Fallible, 1873-The huntsman's letter to the ducal master-The geography of the great hunt-Frank Gillard's narrative of the run -Alfred Earp gives Tom Firr's version of the story-The run, time, distance, and finish-The obsequies performed, and the packs divided-The Rev. J. P. Seabrooke's comment on the runSome of those who saw the run-Two generations of Leicestershire leaders.

\section{PART II}

The past compared with the present-- The Belvoir Saturdays in the Vale — Lady Greenall - The Belvoir field out, Nov. I 4, I908-The Belvoir pack for the day-Steady hunting with the Belvoir in the morning - The Quorn and Captain Frank Forester-The Quorn field out, Nov. 14, I908-The Quorn pack-George Leaf-Will Weston and Blankney memories-The Quorn hunt in the morning-The two packs join in Sherbrooke's covert-Mr. "Ned" Griffith-A fox away-Ben Capell and George Leaf, their horses described-The Belvoir and Quorn whippers-in-The run-What "Q" of the Field said-What "Tally-ho" said-What Captain Forester said-Prominent hounds-Belvoir Ragman-The Belvoir field-master views the fox over the railway embankment-The Rev. J. P. Seabrooke's opinion on hunters-Mr. Henry Cholmondeley out on the right day - Captain Holloway Steeds - The scene near Old Dalby - The hard riders-Near the finish-Capell's whoo-whoop-Lady Greenall presented with the brush-Which fox was it? Mr. A. V. Prior's opinion-Mr. Otho Paget's opinion-Captain Forester's opinion -Lady Greenall decisive !-Dividing the packs-Past, present, and future. 


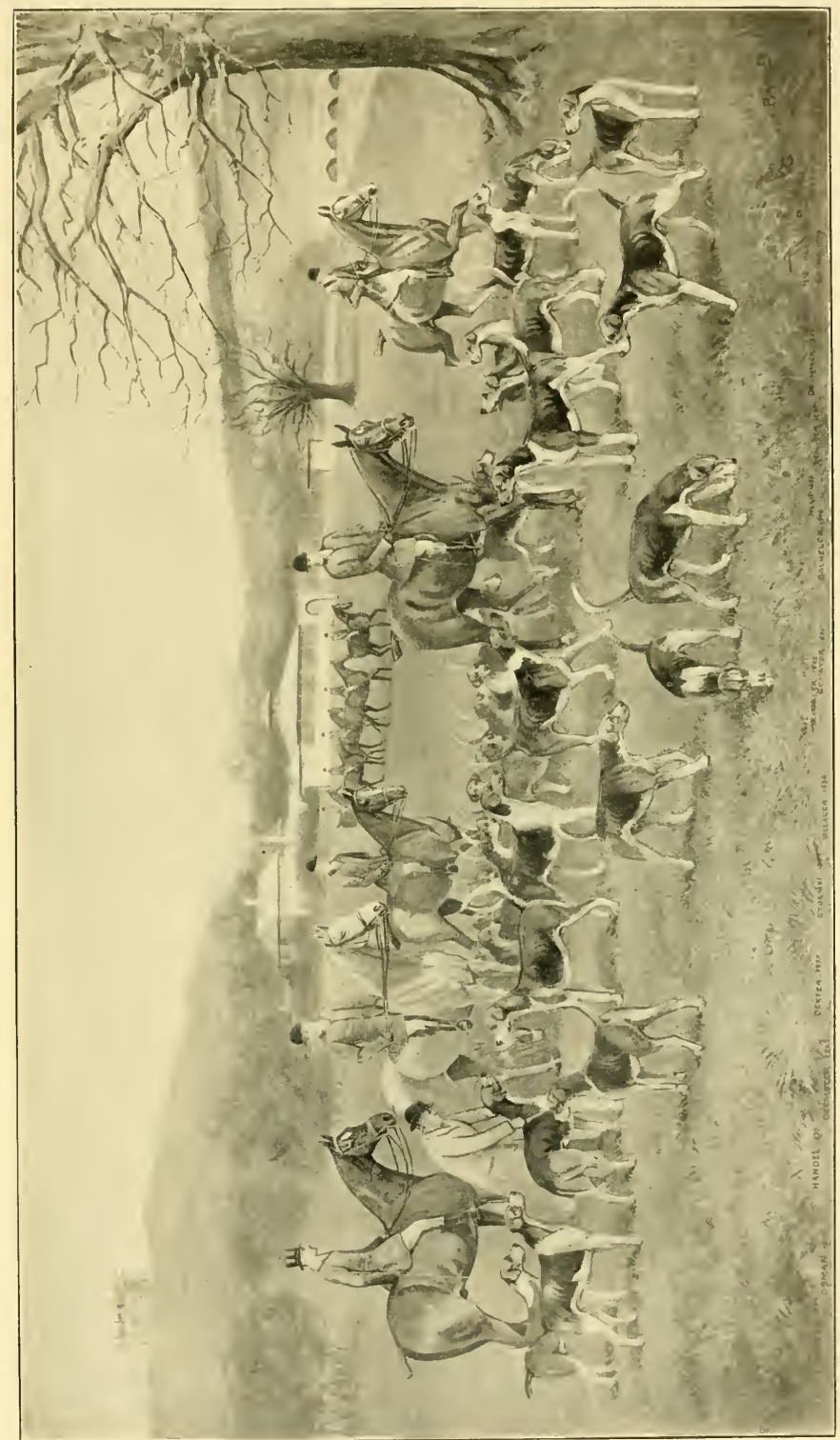

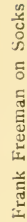

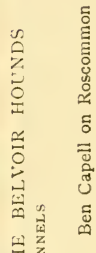

焉焉

는

4

$\exists$

不

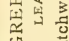

(1) ल

$\stackrel{H}{1}$

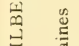

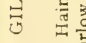

新 



\section{PART I.-The Run OF I 884}

"A wide open brook at this time of day

Is a poser, as most will admit.

Catch hold of his bridle, and show us the way,

Whilst down in the saddle you sit.

Catch hold of the bridle and shove him along,

And o'er the wide water you fly ;

My boy, it's much easier said now than done,

Though many good men have a try.

Yet Custance came up with a rattle, and flew,

Clearing all in his stride, in the famed Waterloo."

-Verses by TOM FIRR.

SATURDAY is the day of the week in Leicestershire, for often during the season there is the opportunity to hunt with any of the four packs, the Belvoir, Cottesmore, Quorn, or Mr. Fernie's, all having appointed fixtures in the classic county. The distance that divides the areas of action is possibly within a fifteen-mile radius, yet it is the rarest occurrence that any two hunts join in chase. The memorable occasions when Belvoir and Quorn have killed a fox in company has only happened twice in the last quarter of a century, the dates being I 884 and Igo8. The story of these two red-letter runs

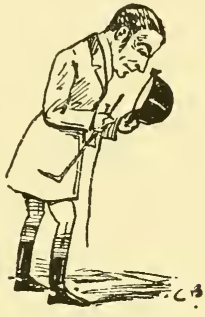

Frank Gillard. gives a fine perspective view of Leicestershire celebrities, past and present being happily linked together by family names and associations, which is the charm of hunting history.

To ride a run and write the narrative of it is the work of two people, and the present chapter is not a one-sided view of two great events, but the opinions of many who were there to see. Frank Gillard gives a graphic story of the hunt of I884, and this has been supplemented by Alfred Earp, huntsman 
to Lord Harrington, who for seventeen seasons rode first whipper-in to Tom Firr. Ben Capell and George Leaf add testimony of the later hunt, so four Leicestershire huntsmen have helped forward the story.

A very memorable day's sport resulted when Gillard was huntsman to the Belvoir and joined forces with the Quorn in a run, Monday, December 22 , I884. Such an occurrence hardly works out in an average of twenty years, although they are neighbouring hunts, whose boundary line is marked by the river Eye, which runs through Melton Mowbray. In Gillard's volume of "Reminiscences," he, records a joint run, with a brush at the end of it, which took place November 25, I878, and it was an occasion which caused considerable friction. To give the history of it briefly, the Belvoir ran a fox very fast from Harby Covert, by Hickling to Curates' Gorse, a Quorn covert. Here the hunted one appears to have lain down, for hounds during half-an-hour's search could not get wind of him. The Quorn pack approached the covert, and Mr. John Coupland, not being best pleased finding the Belvoir in possession, requested Gillard to draw hounds out. Rather a breezy scene resulted when the Belvoir huntsman declined to accede to what he considered a most unreasonable request. At a critical moment a view halloa from George Cottrell, the first whipper-in to the ducal pack, solved the problem, for hounds streamed out of covert and the two packs raced away, killing a well-beaten fox before they had run a mile. The two fields drew up, and the satisfactory finish seemed to act as a salve to the wounded feelings.

At an earlier period, when Frank Gillard whippedin to James Cooper, we find an entry in the diary 
kept by Mr. John Welby, of Allington-February 4, I867: "From Grimston Gorse the Belvoir hounds joined in chase with the Quorn, and, running some way together, killed their fox by Goadby Gorse."

The events of the great day, Monday, December 22,1884 , is the occasion to which we wish to devote space, chiefly because its story brings before us the characteristics of two famous huntsmen of the past, Tom Firr and Frank Gillard. To this day the brush that crowned that history-making gallop is to be seen in a glass case at the Belvoir kennels, cherished as one of its treasured heirlooms, and with it is a print from a long descriptive letter of the run, written by Frank Gillard the same evening, to Lord Charles Cecil Manners, 6th Duke of Rutland, master of the Belvoir.

In the same case with this brush is seen another brush and mask, which has caused rather confused ideas when viewing the trophy; but the explanation is, that they belonged to a fox which gave an eventful run of nearly two hours the day after Lord Forester's funeral.

The printed letter is evidence of Frank Gillard's diligence as a penman, for every evening after hunting, during the twenty-six seasons he was in office, the diary of the day's sport was written up with scrupulous care. In addition to this, the aged Duke, whose infirmities for many years prevented him from being in the saddle, wanted to hear, at the earliest possible moment, a detailed account of all that happened, whether he was in residence at Belvoir Castle or elsewhere. We marve] at such correspondence to-day, because letter-writing is well-nigh a forgotten art! and now the Belvoir huntsman, from the kennels can ring the master up on the telephone, 
giving a summary of what has happened, in the shortest time imaginable.

Frank Gillard's letter is headed with a woodcut portrait of a hound called Fallible ('73), a son of Milton Furrier and Prophetess, a daughter of Rallywood. He showed true foxhound style in every line, and the late Lord Willoughby de Broke, in a letter to Gillard dated from the Warwickshire kennels, March 20, I888, said, "I think Fallible the best dog in England, and I have been to nearly every kennel. He is far superior to Milton Spanker. I am in a position of one, as it were forming a pack. I find I can get quality nowhere except from you and Brocklesby." Others who subscribed to Fallible's worth were the Duke of Grafton, who sent Frank Beers to try and buy him, the price mentioned being $£ 500$. Old George Carter, when he went to look at Belvoir Fallible, the son of his champion dog Milton Furrier, said, "If you will let me have the young dog, I will walk all the way back to Peterborough with him. I won't risk taking him by train." Of Fallible his huntsman used to say, that he was one of the best of three hounds he ever saw on the line of a fox, the other two being Weathergage and Gambler. The celebrated "Gillard compound for distemper," which is in such demand to-day, has Fallible's head stamped upon it.

In the letter dated from Belvoir Kennels, Grantham, Monday evening, December 22, I884, Gillard begins: "My Lord Duke, your Grace this morning was good enough to wish we might have good sport, and it is with great pleasure I now make an attempt to write an account of an extraordinary good hunting run." We may here explain that before hunting Gillard more often than not used to ride a hack up to the Castle to interview the ducal master in bed, 
for he took the keenest interest in the sport, from which he was debarred by gout and accident from following. At the end of the day, if anything particular had occurred, the Belvoir huntsman at once put pen to paper, and the letter was sent by special messenger from the kennels to the Castle.

The letter continues as follows: "Finding our fox at Harby Covert and getting away on good terms, hounds ran very fast in a straight line for Kaye Wood-Coston Bassett; about two fields short of the wood, our fox was headed by a shepherd and his dog, and, turning left-handed, we ran over Pen Hill, crossed the canal, and passed Hose Gorse close on the left, nearly reaching Hose, when we bore to the right, and crossed the road about midway between Hose and Clawson. On reaching Mr. Colman's house, our fox was headed by foot-people and turned back over the road, then going straight for Sherbrooke's Gorse; but, disdaining shelter, he passed the covert on the left, and made his way to the left of Hickling, as if he meant going over the Hickling Standard, but after crossing three fields over the Hickling and Broughton road he bore to the left, and made over the hill just to the right of Over Broughton, and forward for a mile or more in the direction of Willoughby-on-the-Wolds; when a turn northwards took us close to the Curate's Gorse; a man here fortunately headed him-we heard afterwards it was the keeper of the covert, who headed the fox from the breeding earths, which were open. He turned down to the Nottingham and Melton Midland Railway; clinging to the line, crossing and recrossing it four or five times. On approaching Widmerpool Station, Reynard made for a small planting called 'Flint Hill,' which is situated about a mile from Widmerpool-north of the village ; 
here we got up to our fox, and hounds were rattling him about in cover, when all of a sudden I saw the Quorn huntsman galloping up with hounds, and in another minute both packs had joined." It may here be mentioned that the Belvoir had been running their fox for one hour and twenty minutes at a good pace, and having gone straight out of their country, the second horsemen were nowhere to be seen.

Gillard's narrative is full of interesting incident of what happened afterwards. "Whilst standing in the central ride cheering hounds, Tom Firr galloped up with his hounds, just as the fox crossed over behind the Belvoir huntsman's horse, without his viewing him.

"'Tally-ho!' shouted Firr; 'Tally-ho! that's my fox!' 'Now, Tom, behave yourself,' replied Frank, for he saw that it was a critical moment, and did not mean being second best, though on Quorn soil. 'I shall be very angry directly, Tom, if you don't let my fox alone, for you know you had no line into this covert!'" The two packs settled any further argument by opening on the line, rattling the fox out of covert as they went away together. "It was a very lively run, I can tell you," said Gillard, as he brightened up at the thought of it ; " and, as you may imagine, there was a little jealousy between the two hunts, for everybody meant being to the fore. Firr took a most awful imperial crowner soon after starting, carrying away liberal tufts of grass on his coat-tail buttons for the rest of the day. We had to turn to gate or gap whenever it was possible to do so, for none of the second horsemen had come up, and the pace during the first hour of the run had been sufficient to keep horses galloping along. I rode a little snaffle-bridle bay horse all day, named Game-boy, and he made no 
mistake, enabling me to be quickest up at the finish."

Alfred Earp, who was whipper-in to Tom Firr for seventeen seasons, and is now huntsman to the South Notts under Lord Harrington's mastership, gives the following story of the eventful day. "Tom Firr, as every one knows, was one of the best that ever blew a horn, and I am certain there never was one that could speak to a hound as he could, or had such a grand voice. When hunting his fox he was always quiet; he hated noise, and, no matter how bad the scent, I never knew him lose his temper. I have often seen him on a bad scenting day when casting his hounds, and some of the field, as they very often do, keep moving on, he would work his horse broadside on in front of them, and hold them up, so quietly done that they would not realise his move. I always thought him a marvellous man over a country, no matter how big it was; he was always with hounds, never in a hurry; he rode slower at his fences than most people do in Leicestershire, and with rather a loose rein. Like the late Mr. J. O. Trotter-than whom a better man to hounds on a rough horse never was-Firr never lost his temper with his horse, and could get as much out of one as any one I ever knew. On that memorable day when we clashed with the Belvoir at Flint Hill, his words to me were "Watch your own hounds and stick to me!' A little later when crossing a big grass field before we got to the Broughton road, his horse, Revolving Light-a short-tailed brown horse with a white face-struck into an ant-heap and rolled twice over him. He was not a bit flurried, and I do not think Gillard or any of the big field saw it, for we were cutting a corner. Truly he was a tough one !" 
Returning to Gillard's narrative, he goes on to say: "Hounds never wanted much help-not even though there were two huntsmen to assist them ! but when that did occasionally occur, first one handled the pack and then the other: so in this way things worked pleasantly; and our 'fields' appeared to thoroughly enjoy the fun. We ran back over the railway, and the Nottingham and Melton road, in a line for Hickling, passing to the

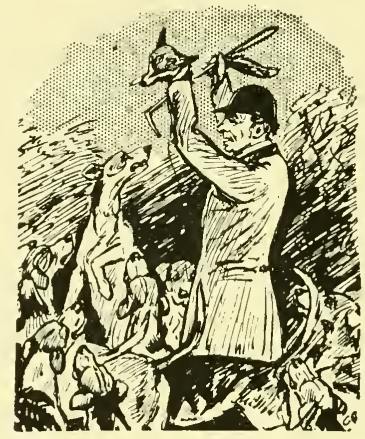

"Who-whoop!"

left of Parson's Thorns, along the hill above the Broughtons to Old Dalby, through the village and Dalby Wood, passing close to the left of Grimston Gorse, on through Saxelby Spinney. I viewed our hunted one away, a big grey dog-fox-close in front of hounds, and I did not think it possible he could run any more than a field or so ; but instead of that, away we went by Saxelby village, after which he bore to the left, and all but reached Cant's Thorns; then taking a sharp turn down into the valley, he succeeded in reaching Welby Holt, or what is now called 'Lord Wilton's Covert,' and after a few minutes doubling about in the covert, hounds killed him. 
Time from finding in Harby Covert, two hours and twenty-five minutes; both packs were running together an hour and five minutes. Measured on the Ordnance Map, the line hounds ran was twenty-six miles. The fastest part of the run was from Harby Covert to Clawson-this was done without a checkand all the other part was at a good fair pace which kept us galloping along.

"I could hear the hounds savaging in covert," continued Gillard, "and was quickly off my horse, knowing there was not a moment to lose. Hounds had broken up their fox, but, as luck would have it,

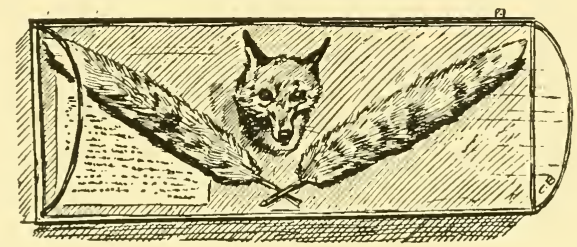

The Trophy.

they left the brush and mask lying close together, so I picked them up before Firr came, putting the brush in my pocket, as I wanted to take it to the Duke, and was afraid one of the field might ask for it. As Firr made no claim, I thought I would not be hard on him, so said, 'Here you are, Tom, you take the mask, as your hounds helped to kill my fox!' A moment later, to my horror, I heard him tally-hoing and who-whooping in the central ride, with every hound round him, and the field looking on, under the impression it was his fox! 'By Jove!' I said, 'this will never do,' and I slipped out of covert, ran about fifty yards down the fence, blowing my horn, and waving the brush about. In a moment all the hounds left Tom and came to me, 
so I cheered and halloed them till I thought he had heard enough of it, and he said to me, 'Now, Frank, we had better take the pack to that gate and draw out our own hounds.' 'All right,' I said, 'let me jump on my horse first.' No sooner was I in the saddle and said, 'Come on, my lads!' than every one of my hounds-sixteen and a half couple of bitches-came to my horse's heels, including one couple of the Quorn, which I had the pleasure of returning next day.'

The sight greatly pleased the Rev. J.P. Seabrooke, who occupied a prominent position all through the gallop, having the distinction of being the only rider who had the luck to see the other combined run, which occurred about twenty-five years later, in Igo8. He remarks in a letter of January I9o9, "Gillard realised, and rose to the occasion at once, taking up the leadership. He was in his glory! Firr seemed dazed for the moment-as well he might after a stunning fall. Gillard and Firr, riding into the midst of the combined pack after the hunt, separated their hounds like two distinguished artists, each hound following his man." Gillard relates that Mr. John Coupland, whom he had served under at Quorn, begged the brush, but, learning next day that the Duke of Rutland was most anxious to retain the trophy as a record of this great run, he returned it.

A full list of the two fields out is not obtainable, but the following are mentioned: "We had a good field out for Harby. It included Mr. Burdett-Coutts, Mr. Francis Crawley, Mr. Edgar Lubbock, Mr. Ernest Chaplin, Mons. F. Roy, Mons. Conturie, and Mr. Lionel Trower, all from Grantham; Mr. Craig, the Rev. J. P. Seabrooke, and Captain Hume representing Melton; Mr. Fisher from Orston; Dr. Williams 
from Coston Bassett ; Mr. Marriott, Mr. Henry Smith, also the Quorn hunt." The first whipper-in to the Belvoir was Arthur Wilson, who afterwards went huntsman to the York and Ainsty hounds.

About this period in history there arrived at Melton a hard-riding trio of friends, the late Captain Tom Boyce, I6th Lancers, the late Captain Parke Yates, many years master of the Cheshire, and Captain Wynne Griffith, Royal Dragoons. For several seasons they hunted from Melton with all three of the Leicestershire packs; and it is a case in point of hunting history repeating itself, for to-day Sir Gilbert Greenall, a nephew of Captain Parke Yates, is master of the Belvoir, married to the daughter of Captain Wynne Griffith.

\section{Part II.-The Run of 1908}

"A stranger, a traveller, stout, gallant, and shy,

With his earths six miles off, and those earths in his eye."

A halo of romance surrounds the doings of the past, the crust of time adding a glamour to the stirring story associated with so many celebrities of the chase, who played their part following the Belvoir and the Quorn in the eighties. If this is true of the past, then we may claim that there is no page in hunting history more full of interest than the story of to-day, when in the enjoyment of health and vigour we take our part in the great drama of the chase. Certainly, after a lapse of five-and-twenty seasons, when the Belvoir and Quorn packs again joined forces in a hunt, killing their fox together, on the memorable Saturday, November I4, I908, there was no lack of enthusiasm amongst the following who rode this history-making gallop. 
The Belvoir Saturday is always an occasion for which the pick of Leicestershire stables are reserved, usually meaning a hunt in the Vale, the finest hunting arena in the world. On Saturday, November I4, I908, the Belvoir fixture was Piper Hole, five miles north of Melton, the weather being mild and the ground dry. A keenly competitive field, representative of three sporting shires, was as usual on the scene, the division from Grantham coming by special, arranged every Saturday by the veteran

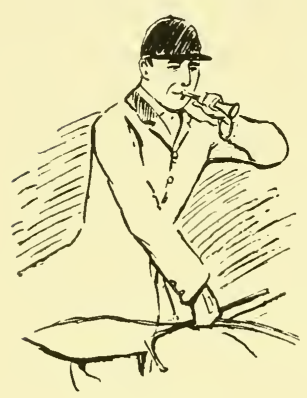

Ben Capell.

Colonel Cotton Theobald, sometimes conveying fifty horses. From Melton and all the other hunting centres for Leicestershire, the favoured covert hack is the indispensable motor-car, for riding to covert is fast becoming a memory of the past.

The assembled field included Lady Greenall, taking the command in the absence of the master, Sir Gilbert Greenall, assisted by Mr. E. W. Griffith, the best of field masters, Mrs. E. W. Griffith, the Duchess of Newcastle, Elizabeth, Countess of Wilton and Mr. A. V. Pryor, Lord Hamilton of Dalzell, Lord Compton, Sir Keith Fraser, Lady Milbanke, the Hon. Mrs. W. A. Lawson, Mr. Cecil and Lady Lilian Grenfell, Major and Mrs. Mann Thompson, the Hon. W. R. Wyndham, Mrs. R. J. Ellison, the Hon. Mrs. J. Gretton, Mrs. Preston, Miss Duncan, Miss Podemore, Captain and Mrs. Arthur Smith, Mr. Algernon Turner, Captain Steeds, Mr. F. H. Schwind, Mr. C. de Paravicini, Mr. R. Millington Knowles, the Hon. H. H. Scott, Mr. R. L. Fenwick, Mr. and Mrs. C. 
Cradock, Miss Muir, Colonel C. Theobald, Mr. and Mrs. F. H. K. Durlacher, Mr. and Mrs. H. M. Escritt, Mr. O. F. Mosley, Mr. P. S. Coxe, Major and Mrs. W. Ricardo, Miss Philips, Captain and Mrs. R. B. Sheriffe, Mr. and Mrs. A. E. Burnaby, Major Bradford Atkinson, Mr. P. Brocklehurst, Major and Mrs. Hobson, Captain and the Hon. Mrs. Cecil Pelham, Captain Ewing, Mrs. le Marchant, Mr. Reynal,

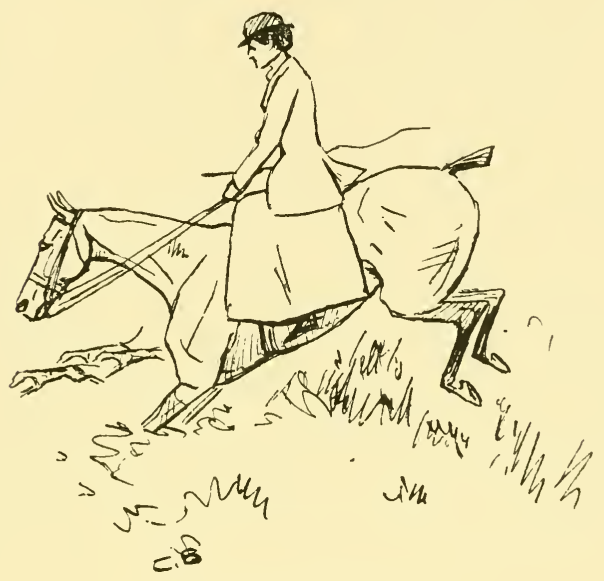

Lady Greenall in command.

Mlle. Landale, Mr. G. Herriot, Mr. A. Mackintosh, Mr. W. Gale, Mr. G. Bellamy, Dr. Smyth, Mr. W. Wilkinson, Mr. Otho Paget, the Rev. R. C. Dashwood, the Rev. J. P. Seabrooke.

The pack for the occasion was twenty-two and a half couple of the big dog-hounds, which Ben Capell may well opine "to be the best he ever saw on the line of a fox since he became a huntsman!" Full of young blood, they look at covert side a pack fit for the gods! Pride of place amongst so distinguished a pack must surely rest between Warlaby ('04), the 
result of a successful out cross with the Grafton, and the favoured sire of the moment at home and far afield, his wonderful son Weaver ('o6), a model of strength and symmetry, having the deepest ribs ever seen on the flags at Belvoir; Ragman ('o6), the son of Royal, the determined-looking fox-catcher; Warbler ('02), the tan dog, always amongst the three rumning at the head of the pack; Helper ('03), with the round close feet, which might be the envy of any cat; Vulcan ('08), the son of the beautiful Weaver, and top of his entry; Smoker ('07) by Stormer ('99), and many more to carry on the fame of the Belvoir blood.

The country-side displayed the leaf and verdure characteristic of October, and scent in covert was only moderate, so that hounds could do little more than harass a fox in Piper Hole Gorse. Better results rewarded the visit to Clawson Thorns, a well-groomed fox leading the way to Holwell Mouth, in which covert several were afoot. Sticking to the hunted one, they followed his line along the hills, a slow scent preventing them forcing him into the Vale, where a better hunt might have resulted. Return visits to Holwell Mouth and Clawson Thorns proving fruitless, Lady Greenall decided to try fresh ground, the order being for Sherbrooke's, fox ground planted by and named after a famous Leicestershire sportsman.

Changing the scene to the Quorn at Lodge-onthe-Wold, ten and a half miles south-west of Melton, Captain Frank Forester was in command of a small field. The master of the Quorn's name calls to mind that of a famous ancestor, Colonel Cecil Forester, afterwards Lord Cecil Forester, brother-in-law to the sixth Duke of Rutland, a very leading man at Belvoir in the fifties, who acted as "warming-pan " between 
two ducal masterships. The field out included General Burn Murdoch, Major and the Hon. Mrs. Tennant, Mr. Henry Cholmondeley, Mr. E. F. Paget, Major C. Johnson, Captain Johnson, Captain and the Hon. Mrs. N. St. Clair Allfrey, Mrs. Horace Peacock, Miss Ashton, Mr. J. W. B. Robinson, Mr. E. B. Brookes, Mr. Tyler.

The Quorn pack in the field were twenty-one and

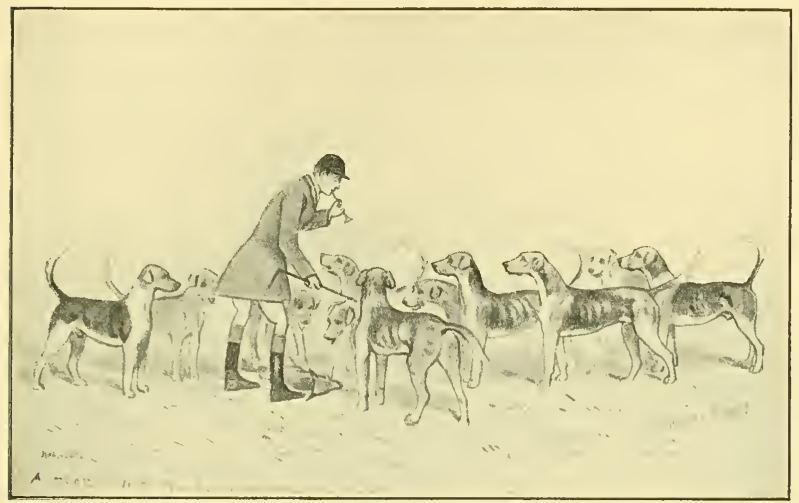

Some of the Belvoir pack.

a half couple, which included four couple of bitches, the full strength of the kennel this season being fifty-four couple, and of these thirty-four couple were by Belvoir sires. The huntsman, starting his first season with the Quorn, was George Leaf, who exchanged from Lord Middleton's with Tom Bishopp, and by his dash and quickness won golden opinions in Leicestershire at once. The first whipper-in, Will Weston, was well known to Belvoir followers, who saw him on many occasions when in the same capacity with the Blankney, under Mr. Edgar Lubbock. 
After meeting at Lodge-on-the-Wold, hounds scored quite a good hunt from Owthorpe Borders nearly to Long Clawson, across a beautiful bit of country by Widmerpool. A longish jog was necessary to get back to Curate's Gorse, from which a fox was set going, and, says Captain Forester, "we hunted up to Broughton Village, then going straight on to Sherbrooke's, the latter part of the hunt was fast. The light being bad, we were within a field of that covert before I was aware that the Belvoir were in possession."

For the best part of half-an-hour a ringing fox had been engaging the attention of the Belvoir pack in Sherbrooke's Covert, and the sudden appearance of the Quorn hounds charging in the bottom end, was hailed with delight by the field! In a moment the two packs joined forces, forty-four couple waking the echoes of Sherbrooke's! It was the moment of a lifetime, though some one asked "Shall we stop them?" Mr. "Ned" Griffith's decisive reply being, "Certainly not, if there is the chance of a run!"”

Any further doubt was settled by a ringing viewhalloo from Jack Hewitt, the Belvoir first whipper-in, riding a good dun horse, Toffee, as he viewed a small-looking fox leaving the Hickling side of covert. Capell's horn came in quick response, animating every horse and rider when hounds streamed out of covert.

Ben Capell being senior huntsman handled the combined pack, Leaf riding at his elbow, charging the hairy fences side by side, remindful of old days at Blankney, when they rode together as huntsman and whipper-in. It is rather singular that both Capell and Leaf were riding short-tailed blood horses of the same pattern and appearance as those 
which carried Gillard and Firr in I884. The bay mare ridden by the Belvoir huntsman was Zephyr, a quick square hunter, with the best of back and shoulders. The Quorn huntsman rode a I5-hand 2-inch bay horse with a white face, a nailing good hunter named Braceby Lad, winner of a three-mile farmers' steeplechase at the Belvoir meeting in 1907 , giving Mr. Garner Bellamy his first winning mount,

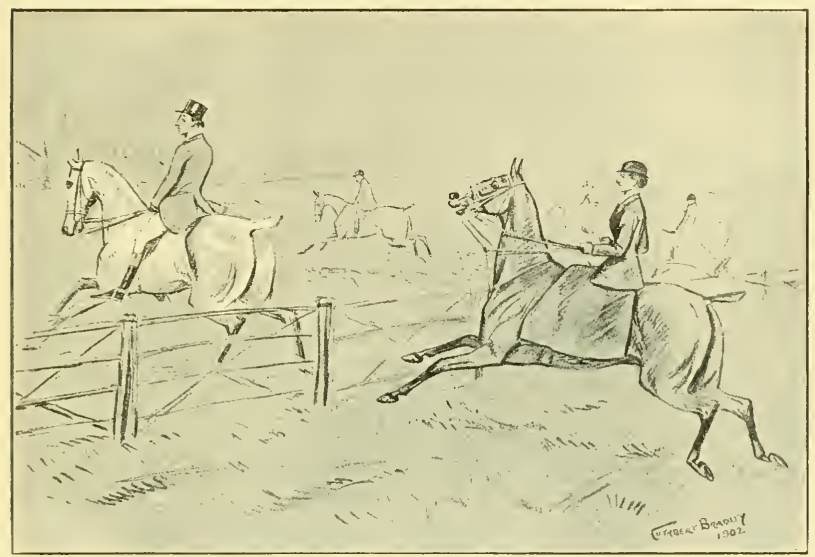

Mr. and Mrs. E. W. Griffith.

and then the property of Mr. G. F. Anyan of Braceby.

The Belvoir whippers-in were Jack Hewitt, who came from the Meynell, and H. Norman, a very good horseman, possessing both hands and seat. Those for the Quorn were Will Weston and J.Goddard, the latter a kinsman of the famous "Jimmy" Goddard, whipper-in to the Cottesmore in the seventies. As Belvoir and Quorn are steppingstones for promotion, the quartette will probably be found at no distant date in the list of huntsmen. 
Settling to the line, the combined pack ran nicely across the grass vale towards Hickling, checking when opposite Broughton, where the fox had evidently been headed. Capell cast down the Melton turnpike road, and hounds hit it off to the right. The remark made by " $Q$ " of the Field, who knows Leicestershire off by heart, was, "It is impossible to find a more charming bit of country; but to be able to appreciate it properly, you want to go a little faster." Tally-ho! the keeper of the Belvoir log-book in the pages of the Grantham Journal, had no fault to find: "The best of all possible lines, the going good, and the scent serving. The pace was just right over the beautiful grass up to Broughton, helping us over the deep Smite, and the hairy fences, which looked bigger than ever with the leaf still hanging on." The master of the Quorn, well carried by a chestnut thoroughbred, Nonsuch II. by Horning, dam Barbrook, was with hounds all the way, and he said "it was a fair, without being a racing scent, just suiting a big lot of hounds who ran very level."

It goes without saying that neither huntsman missed an opportunity of drawing attention to any good bit of work by a hound of his own pack. George Leaf said afterwards, "My hounds did not seem to get settled to their work; they knew there was something strange, but I cheered them on, and then I saw leading, my Diagram ('o8) by Belvoir Ragman, from a bitch by Belvoir Daystar. I pointed it out to Capell, and he was just as pleased as I was to see him. I also saw Belvoir Clasher, Victor, Vulcan, and Ragman make a good hit before we got to the railway."

Roused to energy by the importance of the occasion, a large field were riding along, determined to be with hounds, the pace not being too exacting, 
the combined pack running well together, and Capell cast them twice during the run. Mr. Griffith, riding on the right wing, was well carried by a long-tailed, dark brown Leicestershire horse, Lord John, and the Belvoir field-master was the first to view a very tired fox climbing the railway

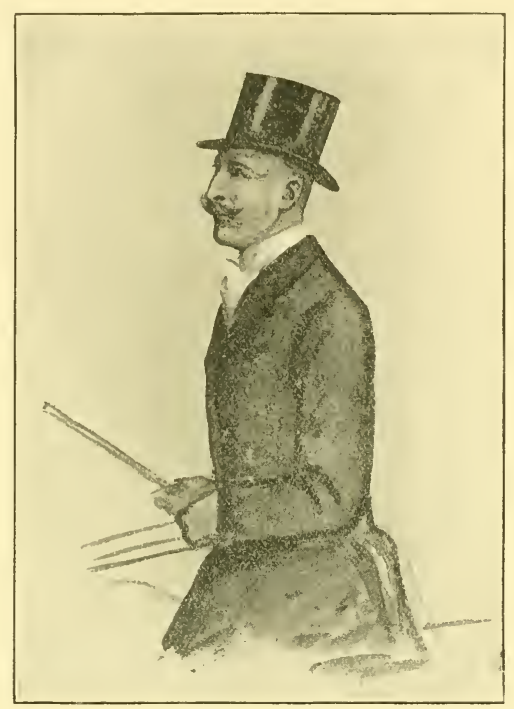

Captain Holloway Steeds.

embankment by Old Dalby Station; Mrs. Griffith, who was riding a favourite chestnut hunter Skylark, also viewed him.

The hunting panorama of grass country, stretching away in ridge and furrow like a vast sea, conjures up a wealth of fox-hunting memories. It was in this district that the previous combined hunt had its issue, and one only had the luck to ride on both occasions, viz., the Rev. J. P. Seabrooke, 
vicar of Waltham. "Were you riding a better horse to-day, your Reverence, than the one that carried you at the top five-and-twenty years ago ?" was asked of the hard-riding cleric. "I don't know, my boy! They all jump! they all j-u-m-p ! if you only let them!" was the characteristic reply. The Quorn huntsman was cheered by a familiar face in the crowd, reminding him of good days seen in Yorkshire, for he remarked, "Curiously enough, amongst those with us was Mr. Henry Cholmondeley, one of the best riders in Lord Middleton's country, on a visit to Major Tennant, and he enjoyed himself very much, though taking a fall over the Smite in the morning gallop." It was Captain Holloway Steeds from Ireland, riding a good grey horse with shoulders and a short tail, who afterwards remarked, "The absence of jealousy was a most charming feature of the hunt; all combining to further sport." It was probably this harmony which crowned the hunt with a kill in the open.

The high embankment by Old Dalby Station, on the railway between Melton and Nottingham, stood out against the setting sun. In the blue distance beyond could be distinguished Old Dalby Wood, rising from the valley to the sky-line, a point a gallant fox hoped to make. Crawling up the steep grass slopes, he was but a mile from sanctuary, and the unwelcome ovation from a gang of platelayers must have been a shock to his nerves. On swept the chase up the valley between the two Broughtons; hounds, with rising hackles as they drew nearer to a sinking fox, chanting a death-knell, which was music in the ear of the two huntsmen cheering them on. As the pack followed their fox over the steep railway embankment, a little band of riders jumped the stiff fence and went with them, including Mr. W. 
Wilkinson from Grantham, " a rum un to follow; a bad un to beat in any country" ; Mr. E. B. Brookes, one of the foremost riders with the Quorn; Mr. Chandos Paravicini, who won distinction as a gentleman rider on the flat; Mr. F. H. Schwind, quite happy on a chestnut horse Solicitor II., a winner of chases; George Leaf, Will Weston, Jack Hewitt, and a few more.

Crossing the double line of rails and the signal wires, the slide down the precipitous grass bank and the jump out again took a bit of doing !

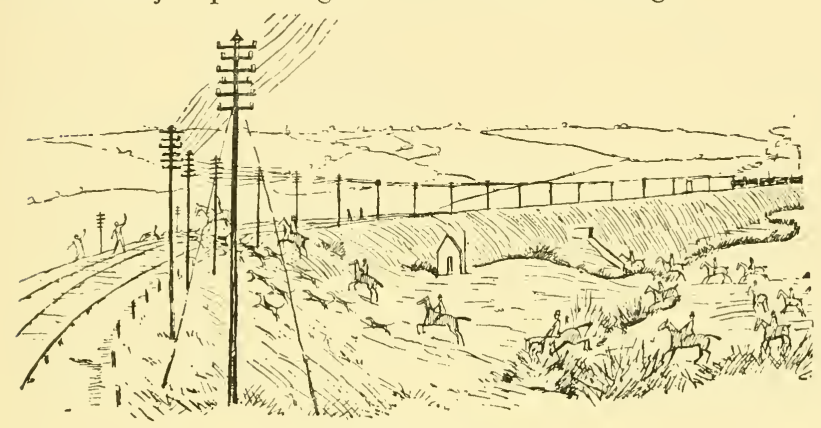

By Old Dalby Station.

Two tunnels, half a mile apart, under the railway served the rest of the field, both Mr. Griffith and Captain Frank Forester being on the right. "Go on for'ard, or he will get into the village, and we shall lose him !" shouted the master of the Quorn to Mr. J. F. Cartmell, joint-secretary to the two hunts, who quickly had a watchful eye forward across the small grass enclosures up to the village.

The tower of the church and the fine gables of Old Dalby Hall, the hunting-box of Mr. and Mrs. C. J. Phillips, were the predominating features of a peaceful little village in the vale, with its background of deep woodland. A field away from 
the railway, behind tall blackthorn fences, Ben Capell's triumphant who-whoop! rang out with electrifying effect on the still evening air. A kill in the open near a big willow-tree had crowned a hunt lasting the best part of an hour, and so savage were the combined pack as they split up their fox that only the brush was rescued.

Lady Greenall, who had enjoyed every yard of the run, well carried by Outlook, a brown horse (an extraordinary jumper and very fast), was presented with the brush by Ben Capell, and it is a treasured trophy for the Belvoir kennel. The nose was all that remained of the mask, and this George Leaf secured for the Quorn kennel.

It will, of course, be always a matter for discussion as to which fox led the combined pack. Mr. A. V. Pryor, the veteran of the Melton hunt, riding a black horse named Sovereign, tells us that " a farmer in the occupation of land near Sherbrooke's told him that when the Quorn were running near there in the morning, two hounds came away from the pack and ran into the covert, where the Belvoir found them later." Mr. Otho Paget, in his account in the Field, remarks, "I never heard of any one seeing their-the Quorn-fox enter Sherbrooke's." On the other hand, Captain Frank Forester points out that there is evidence that it was a Quorn fox, " on account of the way he ran, taking much the same line as we came down to Upper Broughton." Another theory is that the Quorn came to the cry of the Belvoir in Sherbrooke's covert, and that is possible, for Iady Greenall declares that she is quite positive that it was a Belvoir fox which the combined packs hunted and killed.

The last act was the two huntsmen dividing 
the packs, counting them through a gateway before turning homewards, the distance back to kennels being considerable, and the daylight fast disappearing at 3.35 on a short November afternoon.

The special circumstances make every incident of the occasion interesting, and supplies a page of hunting history, linking the present with the past, to animate a future generation of fox-hunters.

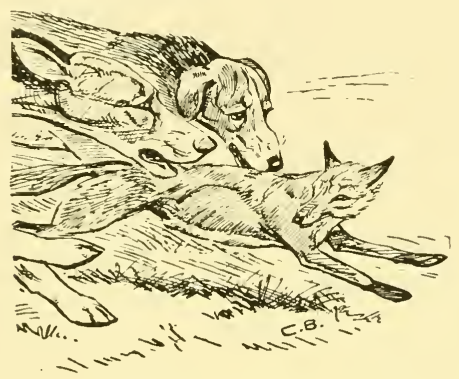

Belvoir and Quorn. 


\section{CHAPTER X}

\section{A HUNT WITH THE EARL OF LONSDALE, VISITING}

THE WOODLAND PYTCHLEY COUNTRY

Visiting hunts tone up the sport-Laxton Park, NorthamptonshireThe field out, Feb. I896, to meet the Earl of Lonsdale-The Brocklesby dog-pack-The dawn of the science of breeding hounds -Brocklesby Rallywood-The three best fox-hound sires in the Rev. Cecil Legard's experience-Will Dale's career-Lord Lonsdale and his hunt staff-A hunt in Wakerley Forest-Boughton ParkOver the Park wall-The Kill-The Pytchley at Owston Wood, April I909-The field out : Cottesmore and Pytchley followers-A hunt and kill from Owston Wood--Lord Lonsdale has a day in the Grove country-Lord Lonsdale's purchase of hounds for the Cottesmore kennel, 1907-8-A story of the Southwold in a strange country.

"Oh! give me the man to whom naught comes amiss,

One horse or another, that country or this ;

'Thro' falls and bad starts who undauntedly still

Rides up to the motto: Be with them I will."

-G. J. IVhyte-Melville.

NEVER do we remember seeing a more representative gathering of the fox-hunting clans than the field which assembled at Oakley Hay, on the borders of Northamptonshire, in February 1896. The occasion was a memorable one, Mr. Austin Mackenzie, master of the Woodland Pytchley, having issued an invitation to the Earl of Lonsdale, master of the Quorn, asking him to bring his private pack and have a hunt in the forest. Lord Lonsdale was no stranger to the country, having served his first mastership with the Woodland Pytchley from I88I to I885, Ben Capell, the present Belvoir huntsman, being his second whipper-in. There was a great air of expectancy about the gathering, which numbered representatives from nearly a dozen different hunts, making up a field of about two hundred, besides a 
A HUNT WITH THE EARL OF LONSDALE I5I large crowd of sightseers. There is a true saying. that it is possible to stay at home until you know nothing, and most certainly this applies to matters of the chase, for much useful knowledge is gained when visiting other scenes and pastures new, the mind receiving fresh ideas and a wider appreciation of fox-hunting. The occasion under ronsideration was one of many, when sportsmen at a distance

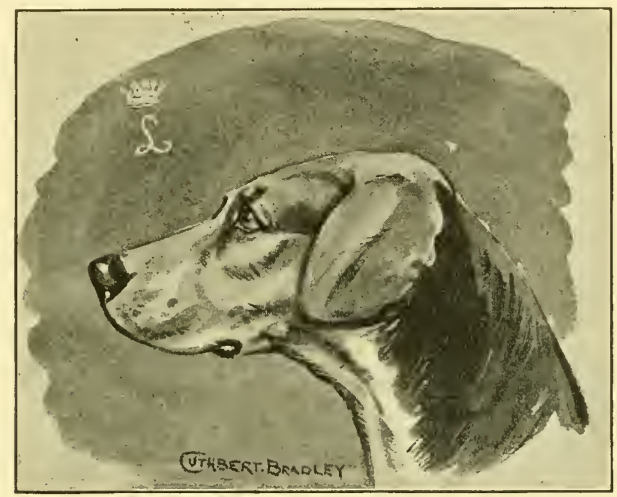

join in a hunt, making a day's sport which has many pleasant associations attached to it. For a huntsman turned loose in a strange land, amongst those who know every inch of the country, it is a severe test of ability to show sport, the visiting hunt generally being full of ride, tuning up the home following to concert pitch. Before night the Napoleon of gentlemen huntsmen, with his famous pack of dog-hounds just purchased from the Earl of Yarborough, accomplished a memorable day's sport, which delighted the large field of professional and amateur critics.

Staying over-night in the neighbourhood at 
Laxton Park, the guest of Mr. and Mrs. James Hornsby, ${ }^{1}$ who had lately taken up their residence there, coming from Stapleford Park, Leicestershire, we learnt something of the nature of the country, which is three-fourths pasture, with strong woodlands. Our host and hostess were well known as staunch fox preservers for the Leicestershire hunts, and at Laxton Park, their new home, soon established the fame of the coverts to supply sport for four packs of hounds, who all meet there during the course of the season, viz., the Woodland Pytchley, the Cottesmore, Mr. George Fitzwilliam's, and the Marquis of Exeter's. From Laxton Park we drove eight miles to meet Lord Lonsdale's hunt at Oakley Hay, whither our mount Hames, a good black horse, had preceded us, with Pygmalion, one of Mrs. Hornsby's favourites, to carry Mrs. Cuthbert Bradley.

The show at the meet was a brave one, two hundred all told in the saddle, some forty vehicles, and a large crowd of foot-people. Lord Lonsdale, with his brother the Hon. Lancelot Lowther, fieldmaster, and a staff of nine in scarlet, arrived with hounds by special train from Quorn. We counted nine masters of hounds and four professional huntsmen in the field, which included Mr. Austin Mackenzie, by whose invitation Lord Lonsdale brought the hounds; Captain Warner, ex-master of the Quorn ; Mr. C. W. B. Fernie, master of the old Billesdon Coplow country; Mr. H. Wickham, exmaster of the Fitzwilliam hounds; Mr. W. R. Erskine-Wemyss, ex-master of the Burton; Sir Bache Cunard, ex-master of the old Billesdon Coplow country; Lord Dalkeith, field-master to his father's the Duke of Buccleuch. The hunts-

1 Mr. James Hornsby's death occurred in March I9Io. 
men were old Tom Whitemore from the Oakley; young George Whitemore, huntsman to the Woodland Pytchley; Thomas Isaac, huntsman to $\mathrm{Mr}$. Fernie, and another from a distance. The lady division numbered Mrs. Austin Mackenzie driving; Lady Augusta Fane, showing the blue facings of the Quorn ; Lady Ethel Wickham, sporting the green collar of the Fitzwilliam; Mrs. James Hornsby, wearing the Cochin-China buff waistcoat of the Belvoir ; the Misses O'Brien, representing the white collar of the Woodland Pytchley. Some of the rest of a large field included Mr. "Bill" Harford on a clean-bred un ; Mr. J. B. Craddock, for so many years hon. secretary to the Quorn hunt ; Mr. Harvey, hon. secretary to the Woodland Pytchley; Captain Holloway Steeds, from Ireland, hunting with the Warwickshire packs; the Rev. Cecil Legard, of Cottersbrook in Northamptonshire; Mr. J. H. Stokes, the well-known horse-dealer from Market Harboro'; Mr. Burk, Mr. Close, Dr. Pink, and many more besides.

Owing to the crowd, it was hardly possible to get a sight of hounds at the meet, for there were many who wanted to look at the much-talked-of Brocklesby dog pack, which Lord Lonsdale had purchased the season previous from Lord Yarborough. The pack for the day numbered twelve and a half couple, bred by Will Dale, huntsman at Brocklesby from I884 to I896, and well known to be perfect in their work as any hounds in England. Mr. Robert Vyner, in Notitia Venatica, published in I849, testifies to the important part that the Brocklesby has played in foxhound history. "Hound breeding," he says, "was at that period as scientifically pursued as sheep-breeding, and the successful perseverance of Mr. Meynell and the 
first Lord Yarborough will ever be deserving of the warmest gratitude from all true sportsmen, lighting up as they did what might justly be termed the dawn of science in the chase." Elsewhere he remarks, "The original stock, from which the most fashionable sorts are descended, are from the pack of the Earl of Yarborough-the family of Pelham having possessed hounds of the same breed for nearly two centuries." Mr. George E. Collins, who published a most interesting book, "The Brocklesby Hound Lists, I746-1903," goes on to say in an article in the Victoria County History of England : "All the best strains in the Brocklesby pack go back to Ranter and Rallywood, and some of the best blood in the Duke of Rutland's, the Duke of Beaufort's, Lord Fitzhardinge's and Lord Galway's packs may also be traced back to these two hounds. Rallywood was perhaps the most famous hound ever bred. His dam, Rosebud, was worked till she was ten years old, and never did wrong in her life. 'The Druid' said that Rallywood virtually made the fame of the Belvoir. He went there when nine years old, and fifty-three couples of his puppies were sent out to walk in the second season. The Rev. Cecil Legard classed Brocklesby Ambrose-a son of Belvoir Senator ('6r) -with Belvoir Gambler and Dexter, as the three best sires in his experience."

Mr. George Collins goes on further to say: "The very best of sport marked Dale's career-I884-96at Brocklesby; frequent successes were gained at Peterborough, while there was the greatest demand for Brocklesby blood from all over the kingdom. Dale was a splendid horseman; he carried the Brocklesby horn twelve seasons, hunting 1282 days and killing I35I foxes-a wonderful record when the high quality of the sport is taken into consideration." 


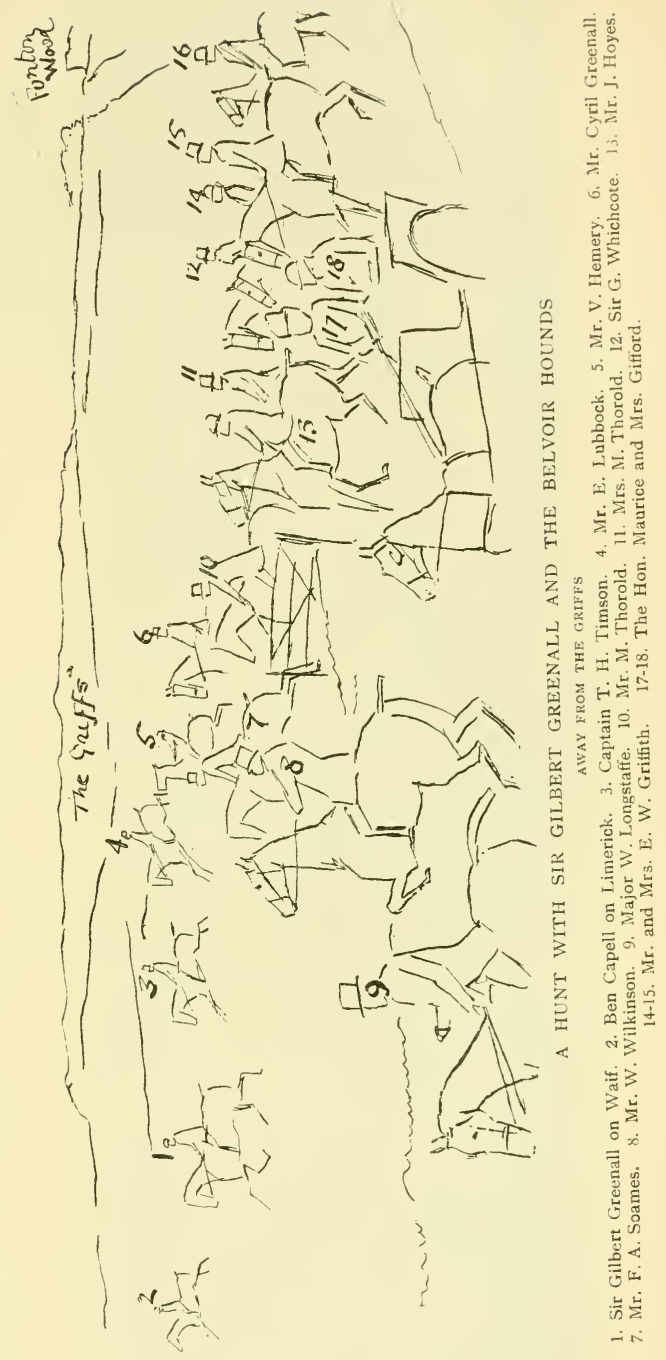





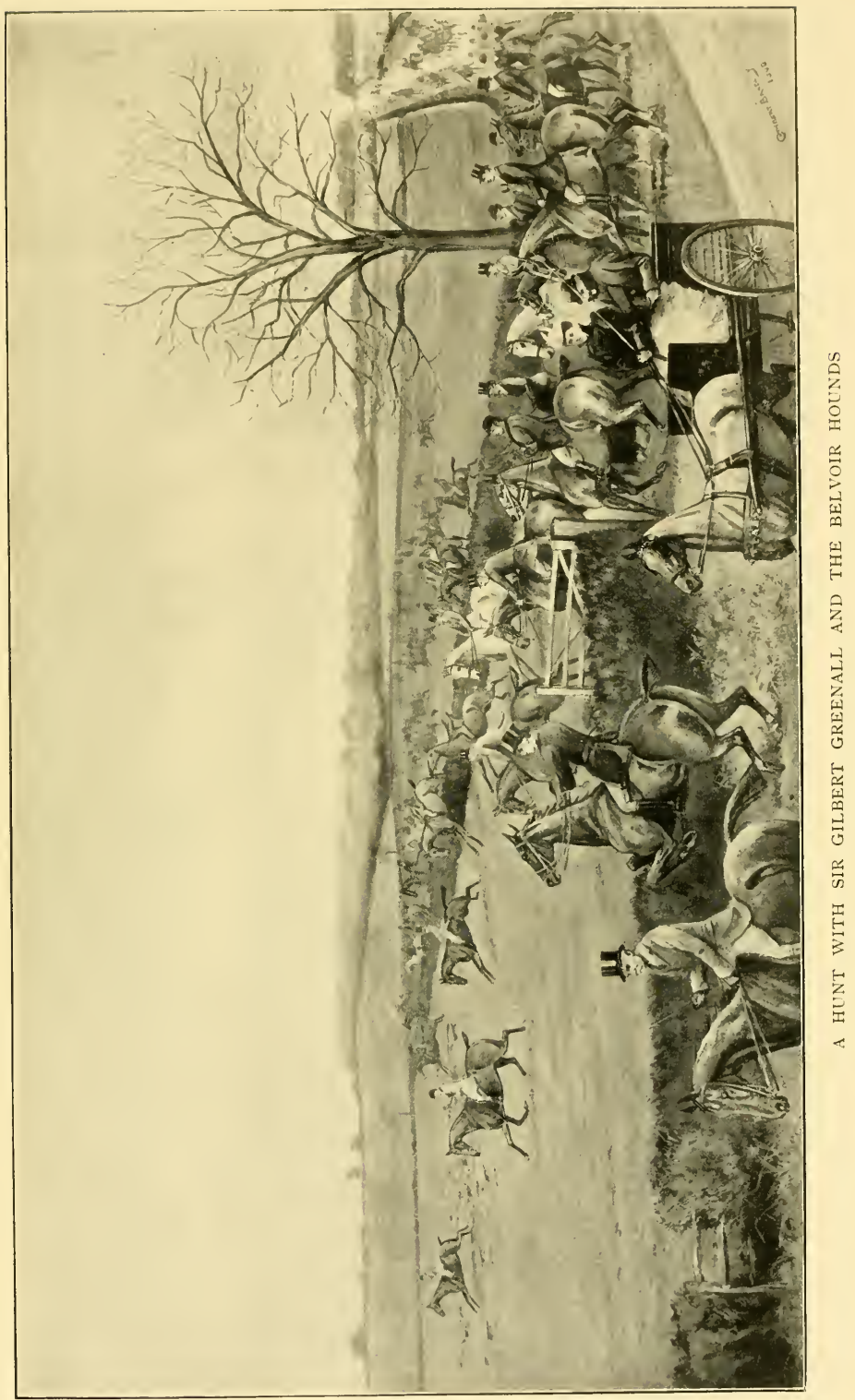



Lord Lonsdale was riding the grey horse White Cap, the big dog-hounds, keen and alert, swarming round the heels of their huntsman's horse as he moved away from the fixture. In type and appearance they were identical with the Belvoir, though the standard of height is nearly an inch bigger than the Duke of Rutland's. All the hunt staff were on bang-tailed chestnuts of a thoroughbred stamp, and never so much as a wisp of mane was to be seen on any of them. Lord Lonsdale's system of hunting hounds is by voice and whistle, though at

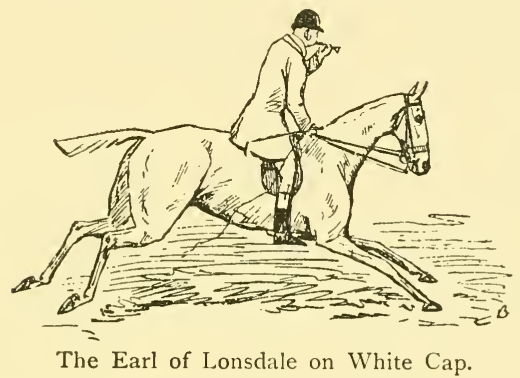

the same time he is a good performer on the horn; and by the way they fly to him, it is easy to see he wins their hearts and confidence.

The hunt moved across to Ruston Blackthorn, a large tract of woodland, but even the deep notes of his lordship's voice and diligent search of the big dog-hounds failed to charm a fox from his lair. The prospect of a scent was none of the best, owing to the bright sunshine and the parched state of the ground, but there was a business-like air about the hunt that foreshadowed stirring events directly the supreme moment arrived. The master's grey horse, recently purchased at Mr. E. D. Morgan's sale for 625 guineas, was handy as a lady's-maid, 
jumping in and out of covert, or scuttling up a ride at best pace, here, there, and everywhere, as hounds worked the large forest. Trotting to Wakerley Wood, an opening note was proclaimed directly hounds touched the covert. Then it was the horn and voice of the master of Quorn, with the silver whistles of his men, raised melody in the fair domains of Pytchley! The pack in full-tongued chorus opened on the line, pressing their fox away on the Oakley side, running across a mile or so of high-scenting grass by Newton and Geddington, holding the Chase Woods on the left, into Weekly Hall Wood, near the town of Kettering. Here they had other foxes on the move, but, sticking well to the hunted one, they chased him backwards and forwards through a chain of coverts, carrying on the hunt in a space of country that might have been encompassed in a four mile ring-fence. A more perfect sporting country in which to get about it has seldom been our lot to see, for grass predominates between the large tracts of wood, whose rides are rolled during the spring, so that they are firm and level as the proverbial race-course. Lord Lonsdale was putting in a lot of work, and had changed from White Cap to the back of a big brown mare Sloppy Sal, always with his hounds and on his fox, in spite of conflicting halloas. His lordship is one of the cheeriest of huntsmen, putting the whole of the field in a good humour, though he rules with firmness, and will not allow hounds to be pressed or interfered with! After a rare dusting in covert the hunted one was viewed showing evident signs of distress, and once again in the open, it was delightful to see his lordship lift his pack, as it were in the hollow of his hand, and drop them on the line again a field away. A good fox had been on his legs before the Brocklesby 

dog-hounds for a full hour, and was glad to turn for shelter to Boughton Park, the Duke of Buccleuch's property. It is on record that a former Duke, disappointed of a wish to plant an avenue from Boughton House to London, solaced himself by

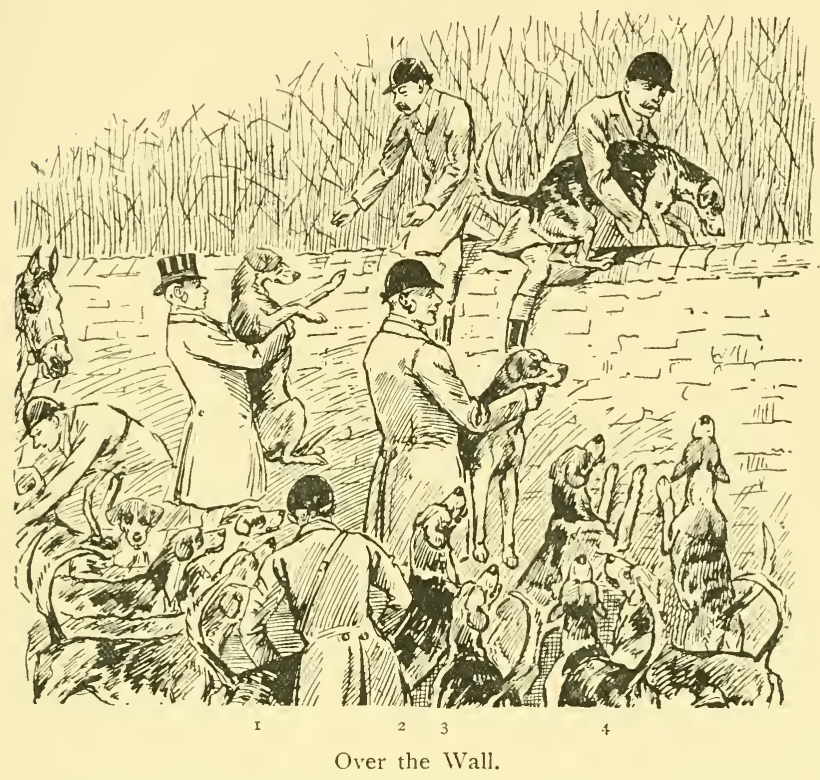

I. The Hon. Lancelot Lowther ; 2. Sir Bache Cunard, M.F.H. ; 3. The Earl of Lonsdale, M.F.H. ; 4. Mr. Austin Mackenzie, M.F.H.

creating an equal mileage within his own property, and to-day it is wonderfully wooded country.

Running to the Boughton Park wall the fox sought shelter in the drain that passes under the road, and here we all pulled up and jumped off our steaming horses to wait, whilst one of the staff went to seek the runner with the terriers. Mr. Austin Mackenzie climbed on to the high wall to see what 
was on the other side, and it was as well he did so, for he viewed the fox leaving the drain-mouth, making off across the park. "Tally-ho! tally-ho!" he shouted, and Sir Bache Cunard climbed up alongside him, whilst Lord Lonsdale, the Hon. Lancelot Lowther, and the whippers-in got hold of some of the big dog-hounds-ninety pounds weight if they were an ounce-and hoisted them up on to the top of the wall. Away we galloped up the road with the rest of the pack to find the gates, and then for half a mile spurted over the old turf to the far end of the park. "Who-whoop!" rang out, as hounds rolled their fox over in the open, making a capital finish to a hunt of one hour and ten minutes. Lord Lonsdale looked supremely happy as he blew his horn in the middle of the baying pack, giving every one time to draw up. The obsequies worthy of the occasion of the death of so good a fox were duly performed, the brush, mask, and pads all going as trophies to representatives of several hunts. So pleased were some of the farmers who enjoyed this run that they persuaded Mr. Fernie to ask Lord Lonsdale to bring his pack fox-catching in the old Billesden country, and they probably had another good hunt to finish the season.

Memories of this day's sport were revived at the end of season Igo8-9, when the Earl of Lonsdale, master of the Cottesmore hounds, invited the Pytchley to come and have a hunt on Saturday, April Ioth. Lord Annaly, who was accompanied by a strong contingent of the Pytchley followers, arrived by special train with Frank Freeman, the huntsman, and hounds.

Owston village was the fixture, close to the large fastness of that name, which Major Hughes Onslow so well described in an article in the Badminton 
A HUNT WITH THE EARL OF LONSDALE 159

Magazine, January I907. "Owston Wood, a huge jungle, close on two miles long, and half a mile broad. It is a grand stronghold for foxes; the wonder is it does not harbour bears and wolves in its impenetrable fastnesses, with meandering boggy rides." The large field out included the Earl of Lonsdale and Lord Annaly, with their respective huntsmen Frank Freeman and Sam Gillson, who are brothers-in-law; the Hon. Lancelot Lowther, Miss Lowther, Lord Edward Spencer Churchill, Mr. C. and Lady Lilian Grenfell, the Marquis of Cholmondeley, Mary Lady Gerard, Lord Alistair Leveson-Gower, General Mahon, Lord and Lady Castlereagh, the Hon. R. Douglas, Victoria, Countess of Yarborough, and Mr. J. Maunsell Richardson, Colonel and Mrs. Blair, Sir F. T. Fowke, Miss Fowke, Elizabeth, Countess of Wilton, Mr. A. V. Pryor, Major-General Coddrington, Lord Hamilton of Dalzell, Major the Hon. P. C. E. Freke, Mr. and Mrs. S. Loder, Colonel the Hon. W. A. Lawson, the Misses Lawson, Miss Naylor, Major Dawson, Major R. B. Muir, Captain G. Powell, Major T. Bradford Atkinson, Captain Poyser, Major Hughes Onslow, Mrs. H. Callender, Miss Callender, Mr. P. C. de Paravicini, Colonel W. A. Peake, Mr. and Mrs. Chaplin, Major Heygate, Mr. J. and Lady Theresa Cross, Major E. G. B. Palmer, Captain H. Wilson, Mr. Niven, Mr. W. A. Chaplin, Major and Mrs. A. Coats, Mr. H. Dixon, Major and Mrs. W. Ricardo, Mr. and Mrs. S. Bigge, Captain Burns Hartopp, the Misses Burns Hartopp, Captain J. W. Burns, Captain the Hon. R. Robertson, Mr. R. Heathcote, Captain E. C. Clayton, Mr. Greville Clayton, Mr. Vere Chaplin, Mr. F. Chaplin, Mr. R. L. Fenwick, Mr. and Mrs. E. G. Fenwick, Miss Tryon, Mrs. Evan Hanbury, Mr. H. Hanbury, Miss Hanbury, Miss 
Finch, Mr. H. C. Bentley, Mr. H. R. Finch, Mrs. Burn, Mr. and Mrs. R. E. Strawbridge, Mr. and Mrs. A. E. Burnaby.

Hounds started by rousing a leash of foxes in Owston Wood running like wildfire in covert, emerging with the chosen one on the Knossington side, doubling back again to the big wood after making a short ring. Driving him into the little wood, they slipped away again from the Withcote end of covert, along the gully up to Launde, carrying a faint line into Prior's Coppice. A brace of foxes were afoot in the last-named covert, and with the chosen one Freeman scored a good hunt of over an hour, before they pulled him down, stiff as a hedge-stake, near to Lady Wood, which forms a link with the larger woods of Owston. It was quite a good day's sport, the greater part of it being over the best of the Cottesmore country, good-scenting ground and perfect riding ground, which could not be improved upon even if it could be equalled.

The Lowther family can claim over sixty years of Cottesmore mastership, and were all houndsmen, the present Farl's ancestors breeding the best of their day, whose blood was sought after by the kennels of the Dukes of Beaufort and Rutland, the Earls of Fitzwilliam and Yarborough. When Lord Lonsdale was elected in 1907 to the mastership of the Cottesmore, succeeding Mr. Evan Hanbury, he strengthened the kennel with purchases of the best blood of the day. The opportunity came with the dispersal of Mr. Reginald Corbet's beautiful South Cheshire bitches, fifteen and a half couple of which were purchased by Lord Lonsdale, who, after seeing them hunt, considered they were worth any money for a country like the Cottesmore. The top of this entry were War-cry ('o6), by Warwickshire Sampson from 
A HUNT WITH THE EARL OF LONSDALE I6r

South Cheshire Wedlock, and the beautiful Belvoirbred bitch Hecuba ('o6), by Belvoir Helper from South Cheshire Crafty, five hundred guineas being the price of the couple. A season later his lordship made further extensive purchases at the dispersal of Mr. IV. M. Wroughton's Woodland Pytchley pack, giving two hundred guineas for a noted bitch, Warranty. Such a store of bitches

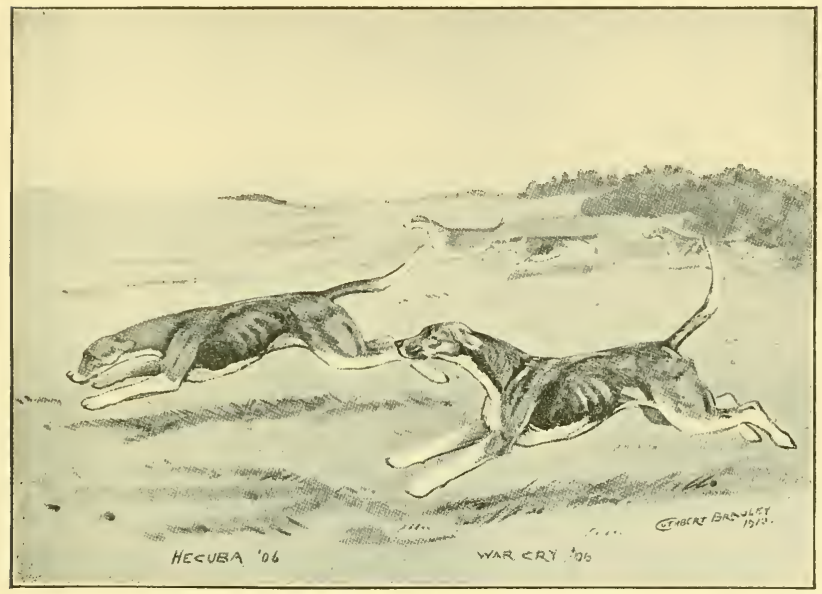

A couple of the Earl of Lonsdale's.

should maintain the high standard of the pack for many a season to come, mated as they have been with proven sires: future entries combining the best blood of the day will be of interest to hound breeders. Lord Lonsdale appointed young Sam Gillson huntsman, a son of old George Gillson, who hunted the Cottesmore for eighteen seasons under Mr. Baird, and Sam gained some experience whipping-in to the Belvoir, afterwards going to carry the horn for the West 
Wilts, and then in the same capacity to the Bedale, a good school for huntsmen.

With the spring of the year and longer hours of daylight, many masters like a change of scene, visiting a neighbour's country with their hounds, gaining new experiences. To conclude the Cottesmore season I908-9, Lord Lonsdale accepted an invitation, taking his private pack, composed of purchases from the North Cheshire and Mr. W. M. Wroughton, to have a hunt in the Clumber coverts, the seat of the Duke and Duchess of Newcastle in the Grove country.

A good story is told of the Southwold hunted by Mr. E. P. Rawnsley, a Lincolnshire pack which shows the best of sport, going in April Igog for a day in the Pytchley country. A very good hunt resulted, for they ran over the borders of the Pytchley to a covert in the Grafton country. Mr. Charles McNeill, happening to be hunting the Grafton pack in the district, saw the strange whipper-in stationed by the covert, and sent his servant to ask who he was. "Where have you come from?" asked the Grafton whipper-in. "Fra Lincasheere!" replied the Southwold whipper-in, airing the dialect of his county. "How far is that?" asked the other, fairly astonished. "About a eight or nine mile point," replied the Lincolnshire man, who had no idea of the geography of the county he was in. Back went the Grafton official to report that the stranger said he had come "an eighty-nine mile point from Lincolnshire." 


\section{CHAPTER XI}

VARSITY DAYS REVIVED WITH THE CAMBRIDGE-

SHIRE AND MR. DOUGLAS CROSSMAN

Memories of days at the Cambridge Varsity-The days of youth-Great sportsmen who graduated at Cambridge-King Edward VII. graduated with the Cambridgeshire hounds and Tom Firr-Mr. G. P. Evans' mastership-Mr. G. Smith Bosanquet's mastership-Mr. Douglas Crossman's mastership-The meet at Grafham Station-The leading lady hounds-Cambridgeshire foxes-Mr. Crossman's huntersMrs. Crossman-The field out-A hunt from Grafham to Perry Woods-Some points of a working pack-A finish and long ride home through St. Neot's-The Cambridgeshire dog-hounds on the flags-Dasher, the dog of promise-Two good days' sport, I908-9.

"Hunting is the noblest exercise,

Makes men laborious, active, wise ;

Brings health, and doth the spirits delight,

It helps the hearing and the sight;

It teacheth arts that never slip

The memory-good horsemanship,

Search, sharpness, courage, and defence,

And chaseth all ill habits thence."

CAMBRIDGE has many pleasant memories for vegetating country parsons, schoolmasters, hard-working M.P.'s, missionaries, masters of hounds, county magistrates, and Jacks-of-all-trades, the University turning out sportsmen as well as wranglers. It seems but yesterday that we watched young Lgraduating in sport over the steeplechase fences at Cottenham, and to the fore in that neck-or-nothing ride with the Varsity drag-hounds. To-day he is one of the most efficient masters of hounds in England. Again it was young W-we all went to hear in the debate at the Union-" For the Abolition of Proctors." The senate was full as we 
hung on his lips, and carried the motion unanimously! Now he is the hope of his party, and weighs the affairs of the nation in the balance. The world is made up of all sorts, and it would never do for all to be born "books in breeches," the events of South Africa pretty well proving that a leaven of hunting, racing, and polo was very useful in the hour of need to stiffen up the defence of the nation. When looking through a sketch-book of Cottenham university race-meeting impressions, we found amongst the undergraduates who sported their family colours, and rode gallantly over the two and a half miles of country, many names to-day that are to the fore in the camp, the senate, and the world of sport.

Probably, amongst many successful owners of horses, whose colours are borne to victory for the great classic events and prizes of the turf, there are some who look back to one of the proudest moments of their life, when for the first time they donned silk themselves at Cottenham, and with many a peck and scramble steered a good old slave to win the lasting laurels of fame. What energies these happy days fostered, the memory of which kindles the latent fires that for a time may have remained dormant within us, those quickening reminiscences of the sports and pastimes of youth.

Mr. J. Maunsell Richardson, the pilot of Disturbance and Reugny in their Grand National victories, reminds us that it is nearly half a century ago when, an undergraduate at Cambridge, he rode together with the present vicar of Waltham, the Rev. J. P. Seabrooke, over the steeplechase course at Cottenham. To-day both can go to the top of a Leicestershire field in a quick thing with hounds, and stay there, though two younger generations of 
riding talent may be blazing along to get the lead. The Rev. Cecil Legard was another who took a sporting, as well as a clerical, degree at Cambridge. The list of masters of hounds includes many who rode and played polo when at the Varsity, the best of schools for horsemanship, foremost being Mr.

J. Maunsell Richardson, for some time master of the Brocklesby during the minority of the Earl of Yarborough. Then there was Mr. C. B. E. Wright, who held three or four masterships, including the Badsworth and Fitzwilliam; Mr.

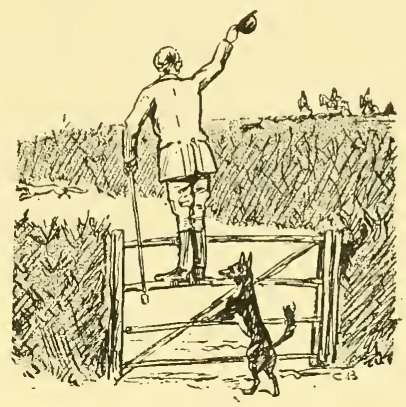

A View-halloa. Roland Hunt, master of the Wheatland; Mr. C. D. Seymour, for many years master of the West Norfolk ; Earl Fitzwilliam, who hunts the Wentworth and the Grove, when Lord Milton was a keen competitor at Cottenham, his grey mare Mary, as good a hunter as ever looked through a bridle, winning more than once. The Hon. Lancelot Lowther was another of the riding division from Trinity who has since ably filled the post of deputy-master to the Quorn and Cottesmore during his brother the Earl of Lonsdale's masterships. The list of first-class polo players is full of Cambridge talent, including Mr. W. S. Buckmaster, who when at the University in the nineties rode brilliantly with the Cambridgeshire and the Fitzwilliam.

"Oh, for the glamour of youth!" is a quotation from one of the latest novels, but the lament is a vain one, for perpetual youth is to the fore at Cambridge; no matter in what decade we may revisit 
the Alma Mater of learning, there is always sunshine and lightness of heart in evidence.

Many trace their earliest hunting experiences to days seen with the Cambridgeshire, which presents every sort of country to ride over, the fences being of a practical kind and the going sufficiently deep to steady the ardour of the most abandoned thruster. During the mastership of Mr. Charles Barnett, r829 to 1867 , King Edward VII. was in residence at the University, and it was old "Jack" Press's proudest boast that when huntsman to the Cambridgeshire hounds, he was tipped by his Royal Highness. Another who may be said to have learnt his earliest lessons with the Cambridgeshire was Tom Firr, second whipper-in to Jack Press, and in that capacity he may possibly be remembered by veterans whose college days date back to the sixties.

Our first visit to the Cambridgeshire kennels was in the mastership of Mr. G. P. Evans, who was in office nearly nine seasons, carrying the horn himself, greatly improving the pack with a liberal infusion of Belvoir blood. He mounted his staff on hunters of beautiful quality with the right substance, his reign being memorable for a high average of sport. Succeeded by Mr. George Smith Bosanquet, who held office for three seasons, keen as his predecessor in all matters concerned with houndbreeding, also going to Belvoir for improvement. During this period of mastership the Hon. Lancelot Bathurst, for some time hunting editor to Land and Water, carried the horn successfully, and was followed by John Budd, contriver of foxhound puppy " foster-mother." Medium-sized hounds with plenty of pace were found best suited to the requirements of the country, which has some rough heavy going. 
We had the opportunity to enjoy a sight of the Cambridgeshire hounds in the field and in the kennel at the end of season I9o8-9 under most favourable circumstances, the guest of the master Mr. Douglas Crossman. Talking of hounds by sires whose family characteristics are known to us is always full of interest, especially in the case of the Belvoir, where the strong family likeness is so pronounced. Beginning with the day's hunting, which we saw after making an early start from Lincolnshire to catch the first express up to Huntingdon, we happened to choose the wettest day of the year, and the last of the Cambridgeshire season. Boarding the motor at Huntingdon, we travelled nine miles to covert with Mr. and Mrs. Douglas Crossman, the rain penetrating every sort of wrap and covering as we swished along over excellent level roads. The view all the way was good typical hunting country, plenty of grass land with the hedgerows well timbered, and in the far distance, on a ridge of high country, there appeared a large extent of forest.

The meet was at Grafham station, where a nicesized field had assembled in spite of the discomforts of heavy-falling rain, numbering several ladies, who always look more cheery under these trying conditions than do the sterner sex. Hounds had arrived after a long trot by road, the only sort of "dog" one would have thought of turning out of doors on such a morning, much less expect to show sport in a country which every hour of the day became more water-logged. In the absence of the huntsman, on the sick-list, the two whippers-in were in charge, Frank Tucker and Mike Cullerton, mounted on blood-hunters, for the Cambridgeshire country requires a well-bred, stout horse to gallop on in deep going and jump every sort of fence. The 
pack for the day was thirteen and a half couple of bitches, a determined-looking lot, full of muscle after a hard season's work. With a few minutes to spare, Mr. Crossman pointed out some of the leading lady hounds, Sunlight ('04), a five-season hunter, being a very nice stamp of medium-sized hound, by Belvoir Dexter ('95) from Sunbeam ('99). Showing the Belvoir tan colouring with a distinguishing white collar, later on in the day we saw her put them all right at a critical moment when they had flashed over the line. Vanity ('o6) was another nice bitch by Belvoir Valesman ('02) from Dusty ('02), with good neck and shoulders. During the season she raced out from the pack, and killed her fox single-handed. Cambridgeshire foxes take some catching, the coverts being large, with a good deal of rough going between, and even on a good scenting day they can lead hounds for forty minutes. Diligent ('o8), by Dashwood ('o4) from Brazen ('04), was a very nice turned bitch, as good-looking as anything in the kennel, black-and-white pied, with a tan head. Damsel ('08), by Fitzwilliam Donovan ('05) from Blithesome ('02), had a very sporting appearance, just the type for a brood bitch, and another of this entry was Dutiful ('o8), by Oakley Broker ('04) from Promise ('o4), not a taking-looking bitch when seen on the flags, but in the field a nailer in her work, running at the head of the pack.

Mr. Crossman carried the horn in the absence of his huntsman, and for that reason we congratulated ourselves on having chosen this particular occasion to see the Cambridgeshire in the field, for the master when living in the Meynell country, where he learnt his hunting, was one of the best of a hardriding field. The two horses to carry Mr. Crossman were brown bays, short-tailed blood hunters with 
the best of backs and shoulders, standing on short legs, a type impossible to get away from! Burnaby was the first mount for the day, and Bengal, the favourite, was in reserve for the afternoon, showing a white star and a dash of grey hairs in his tail-a beautifully balanced horse and a finished performer.

Mrs. Crossman, who has hunted all her life, was well known in Essex on her noted mare Ruth, and before that in the Meynell country when Miss

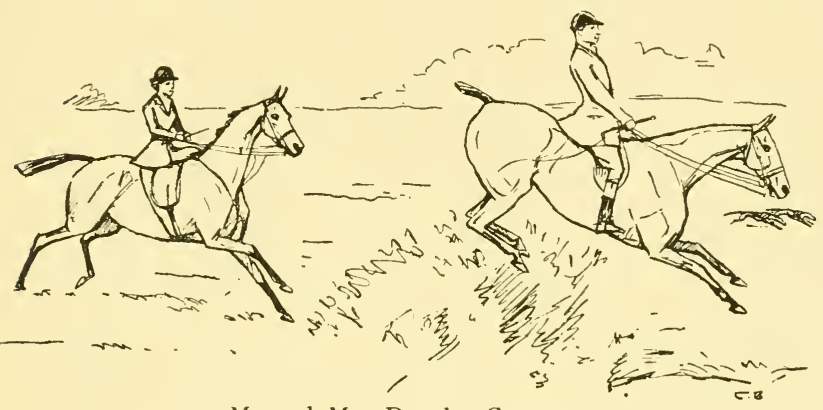

Mr. and Mrs. Douglas Crossman.

Eleanor Dawson. The master's wife now rides a thoroughbred stamp of hunter, Lady Jane, a brown bang-tailed mare, being the first, and Ninette, another that looked like racing, being the second for the afternoon hunt. Amongst the assembled field was the veteran cleric the Rev. Kirke Smith, rector of Boxworth, riding a strong chestnut; Miss Browning, the daughter of a former Oakley master; Captain Morrison Bell, riding a bang-tailed black horse; Mr. Lomax, Mr. Hodgson, Count Tisa, one of the heavyweight division, riding a chestnut; Mr. Alexander, Mr. Jordan, and Mr. Sheddon, both of polo fame; also Mr. W. A. Fordham, the hunt secretary. Unfortunately the Cambridge men were down, so none 
of the University division were in the field to add to the gaiety of the scene.

For the first draw Mr. Crossman took us to Grafham Wood, a nice, thick covert on the hillside overlooking an extensive vale away for Spaldwich Church and windmill.

A master always scores an advantage hunting his own hounds, enabling him to judge which strains of blood do best for the kennel. A fox was quickly on the move, and the full-toned chorus proclaimed a scent, setting the field scurrying hither and thither in eager haste, glad to restore circulation in the pitiless downpour of chilly rain. After a turn round covert they forced him out over the railway, and we ran a ring across a heavy bit of country, back over the line into Calpher Wood, with the master and Mrs. Crossman leading the way. Once in covert again they ran as if snapping at his brush, but he just managed to give them the slip, and a halloa proclaimed them away over the grass, back to Grafham Wood. Never leaving him, we were soon again in the open, shaping our course through Savage Spinney, with Perry Wood looming in the far distance. This would have been a nice line to ride under favourable conditions, but every brook was swollen into a river, and every furrow had the proportions of a wide brook, making galloping heavy work for the good dun mare we rode.

In Perry Wood the hunted one shifted responsibilities on to the shoulders of a friend, and by doing so made good his escape. As Mr. Crossman summoned hounds out of covert, he pointed out Sylvia ('O3), a six-season bitch by Grafton Danvers ('oo), who had been leading them all the morning. Then there was old independent Sun- 
light, all right on her day, but never one to stand much knocking about. Dutiful, too, came in for praise, a racing-looking bitch in her first season by the Oakley Broker, and George Baker the huntsman told us next day, when we met him in kennel, that this dog had done well as a sire for the Cambridgeshire, getting the right sort for work.

Another hunt started from Mudloe Wood, and this time we had better going on the grass across Gaynes Park, which carried a useful scent. A lead over the sunk fence was given by the master, fol-

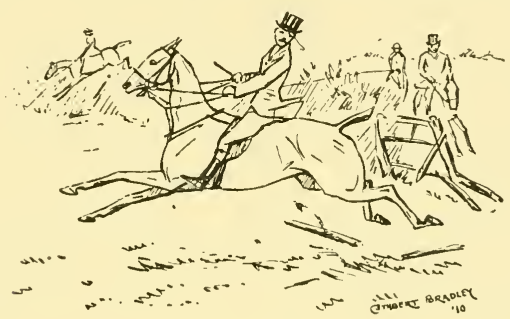

One to follow.

lowed by a stranger lady, and Count Tisa. Then after an intricate bit of hunting, necessitating the negotiation of one or two widish places, hounds ran in delightful fashion over the rising grass country into Perry Wood, a stronghold which has enabled many a fox to elude his pursuers. On the journey homewards in the dusk, a ride of twelve miles, we pulled up at the Cross-Keys, an old-fashioned hostelry at St. Neot's, where the horses had gruel, and the hunt servants a well-earned "bite." Very welcome were the lights of the master's house, Gramsden Hall, by Sandy, where we arrived just in time for dinner, and, after struggling out of waterlogged boots and hunting kit, which we had donned twelve hours previously, the creature comforts of a 
warm house after a rough day in the open were never more appreciated.

On the flags at kennels next morning in welcome sunshine Baker showed us the dog-hounds, which included the veteran Bedford ('OI) in his eighth season, by Mr. Pole's Bender ('96) from Meynell Spotless ('93), being one of three couple which Mr. Gerald Hardy drafted from the Meynell kennel. A rare dog in his work who could do anything with a fox, Bedford was well coupled up, possessing excellent neck and shoulders. The biggest dog in kennel, and at the same time said to be one of the best in the field, was Rummager ('05), by Warwickshire Sampson ('oo) from Ruby ('98), a determined-looking fox-catcher, with a very taking style about him. Prodigal ('o8), by Oakley Broker ('04) from Promise, was a 23-inch hound full of promise. Blue Cap ('04), by Grafton Danvers (Igoo) from Blissful (Igoo), a cobby hound, rich in colour, a good-wearing sort.

The dog we liked best of all was Dasher, who came into the entry of I909, a very promising hound by Fitzwilliam Plato ('o7) by Potent, a lightcoloured hound like his sire, both winners at Peterborough, from Daffodil ('o6) by Belvoir Daystar ('03) from Sunbeam ('99). Dasher with luck looks like making Mr. Crossman a hound to put forward at Peterborough; for he stands well on good feet, has deep ribs, carries his bone down, and is a dog with some size about him, whilst his breeding is undeniable.

The two best days of the season Igo8-9 happened before Christmas, Mr. Douglas Crossman hunting hounds himself. On November I 7 th, when riding Bengal, after a useful hunt in the morning, a fox was roused in Grafham Wood about two o'clock in the afternoon. Hounds ran straight 
through Calpher Wood on to Burton Sticks without hesitating a minute, racing on to cross the Stowe road, right-handed to Spaldwick village, the time being twenty-five minutes. Recovering the line, they ran right into the Fitzwilliam country by Barham to Wright's Gorse, past Hamerton to Solom Wood, and were stopped at dusk. Only a dozen got to the end, the extreme points being eight miles or sixteen as hounds ran.

On December I8th, after meeting at Packington to spend the morning hunting round that district, a good fox was started about 2.30 in the afternoon from Knapwell Grove. There was a capital scent on the ploughs as well as the grass, hounds running by Boxworth village away to Childerley Hall to the Belt at Madingley, where a shooting party headed him. Turning left-handed through Drayton village, they crossed the Huntingdon road and went straight on to Packington village, where they lost at dusk. The time was one hour and twenty minutes, the extreme points five miles, although hounds ran much farther.

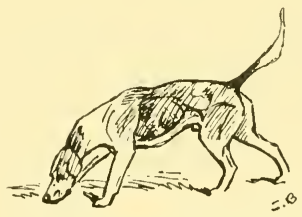

Cambridgeshire Dasher ('og). 


\title{
CHAPTER XII
}

\author{
FOX-HUNTING JEHUS, PAST AND PRESENT
}

The old road and its influence-The origin of steam-rolled roads-

Cuthbert Bede's title "Down the Road"-Mr. C. T. S. Birch Reynardson, the gentleman stage-coach driver-Old professional whips-Tom Hennesy's crooked whip-The revival of coachingThe music of a trotting team-The coach welcomed all down the road-Mr. Alfred Vanderbilt's "Meteor" coach-The size of a coaching stud-The Earl of Lonsdale's postilion and harness horses - The Earl of Lonsdale's driving feat against time-Coach-driving competition at Hurlingham and Ranelagh - The coaching Marathon race-Mr. Lewis Priestman's "Venture" coach-The team of greys - Hunt horses as coach horses-Young horses-Hirelings-The appointment of the "Venture" coach and harness-A coach drive from Scarborough-A Yorkshire view-Reliable teams in heavy trafficA sporting chestnut team-The end of the journey-A pleasant thought for the future of coaching.

"Alas! alas! where have they gone,

The coach, the bays, and greys?

Alas! alas! where is it gone,

That 'Light of other days'?

The sun has set that once shone out

So bright upon those teams ;

The night has come, and all that's past

Seems but as fleeting dreams."

-C. T. S. Birch Reynardson (from "Down the Road").

REsiding within sight of a fine old main-road prompts the spirit of travel quite as much as the accident of being near water stirs the inclination to become a disciple of Isaac Walton. Of late years the wide coach roads that intersect the counties hunted by the Leicestershire packs have proved the greatest service to the large division who now 
travel to covert by motor-car. In the days of our forefathers they were, of course, the main arteries for traffic up and down England, and their milestones, with distances marked in plain figures to or from London, seem to put the country-side in touch with the populous city which gains enchantment when contemplated from a distance! Nothing short of a hundred miles from the great metropolis can be considered a safe distance to ensure tranquillity of rural peacefulness or absence of smoke taint to destroy the pure air, which is the charm of Leicestershire or Lincolnshire.

There are still a few people left to compare the past with the present, and from their account it would seem that the dust and danger on the roads in the coaching age was just as formidable as it is to-day where there is heavy motor traffic. For twenty years the roads were well-nigh deserted when coaching went out and steam came in, and it is to the institution of the motor-car that we owe the better state of things from the general use of the steam-roller.

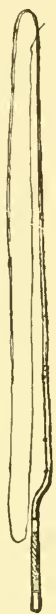

Tom Hennesy's whip.

As the saying is, "It is an ill wind that blows nobody any good," and when the revival for driving does set in, as sure enough it will when the craze for speed has run itself out, then there will be the perfect roadway such as our forefathers never imagined.

In the seventies we came under the influence of a coaching celebrity, the late Mr. C. T. S. Birch Reynardson, the squire of Holywell Hall in Rutland, who frequently drove over to see my father, the late Rev. Edward Bradley, rector of Stretton, a pretty 
little parish by the side of the Great North Road in the Cottesmore country. Mr. Reynardson would talk by the hour about his coaching experiences seen in the twenties and thirties, and my father, who was better known as (uthbert Bede, author of "Verdant Green," persuaded him to put them on paper. The result was an interesting volume "Down the Road, or Reminiscences of a Gentleman Coachman," a title which my father invented after revising the manuscript. The book was illustrated by coloured plates from Alken's coaching. pictures, which adorned the walls of Holywell Hall, and the old squire to the last resented " the teakettle with its steam taking the place of four bright bays." In his opinion the greatest pleasure in the way of "sport" was as a gentleman coachman to drive a real mail or genuine passenger four-wheeler of the olden time, by night and by day, in summer and winter, tempest and snowstorm, as though earning a livelihood by the work.

He further relates that his instructors were first old John Barker, driver of the " Regent" coach, from Stamford to Huntingdon in I823, afterwards Tom Hennesy, coachman to the " Regent " between Huntingdon and London; others being Dick Vickers of the Shrewsbury Mail, Sam Hayward of the Shifnall Coach, Charlie Harper of the Chester Mail, Peter Hilton of the "Hirondelle," Jack Williams, Harry Vyse, Will Jones, Shaw of the "Nettle," and some others, " noted whips."

"Down the Road" possesses an historical value as a volume, being the faithful reflex of a system of things that have now had their day, but have not lost their interest for the present generation.

Amongst a large collection of whips, walkingsticks, and alpenstocks which the old squire had in 
his favourite sitting-room at Holywell Hall, we remember Tom Hennesy's crooked whip, about which he relates the following story of how he became its possessor : “' If you'll promise me that you'll take it clean out of the country, and never bring it into these parts again, I'll make you a present of it.' On these terms I became the happy possessor of the dog-legged stick; and, though I have driven hundreds of miles with it on other roads, it has never been a single mile on the London side of Stamford."

It is a fortunate fact that the sporting spirit still animates the Jehu of to-day, and the wish to

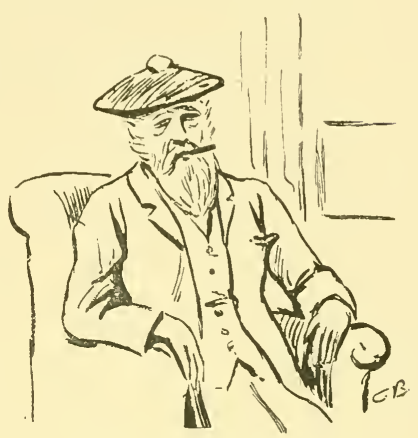

Mr. C. T. S. Birch Reynardson. excel prompts the leisured class with means, to revive the "glories of the road." Although the fourhorse coach cannot compete with the locomotive and motor-car as a means of transit, coaching ranks amongst the most manly sports an Englishman can take up. To such thorough sportsmen we owe the institution of the summer passengercoach, running daily on the breezy downs and sunny uplands within distance of fashionable coast towns and inland resorts. This mode of travelling at a moderate pace amidst the beauties of scenery, is one of the most pleasant pastimes to be found in England-restful to a nervous system overwrought by the craze for speed in this hurrying age.

To any one of sporting instincts with an ear for music, there is no finer trotting march than that played by the iron heels of four horses with equal 
action. The appearance too of a level team going well into their collars, as only generous-bred ones know how, is an inspiring sight, unrivalled at present by any mechanical means of transit valued at thousands of pounds. Certainly all the way down the road the approach of the coach is heralded with signs of respect and delight by a rural community. Everywhere you may note the daylabourer, the shop-keeper, or the travellers on the road, proud to catch the coachman's eye and wave a welcome. Those who are the stragglers of a past generation go farther still, taking off their hat to the coach, remaining uncovered until it has gone out of sight. The country-side is cheered and animated by the appearance of the coach, in the same way that every one turns out to get a view of hounds passing by.

During the past three summers London has welcomed Mr. Alfred Vanderbilt from America, reviving the "Meteor" coach with a regular service to and from Brighton. This is certainly a matter for congratulation, because many had begun to think that the fine old road was lost to coaching-a prey to modern nuisances. About sixty horses, brought from America, work the coach, eight changes being made during the course of the journey, the enterprise necessarily being a costly one.

A coach which covers a long distance daily at a regulation pace requires, roughly speaking, one horse to every mile of ground. A team will do a stage of five or six miles at top speed, with less wear and tear to themselves than when longer stages of ten or fifteen miles are covered without drawing rein. It is therefore a matter of economy to keep a large stable and furnish frequent relays, when time has to be kept and the roads are hilly. 


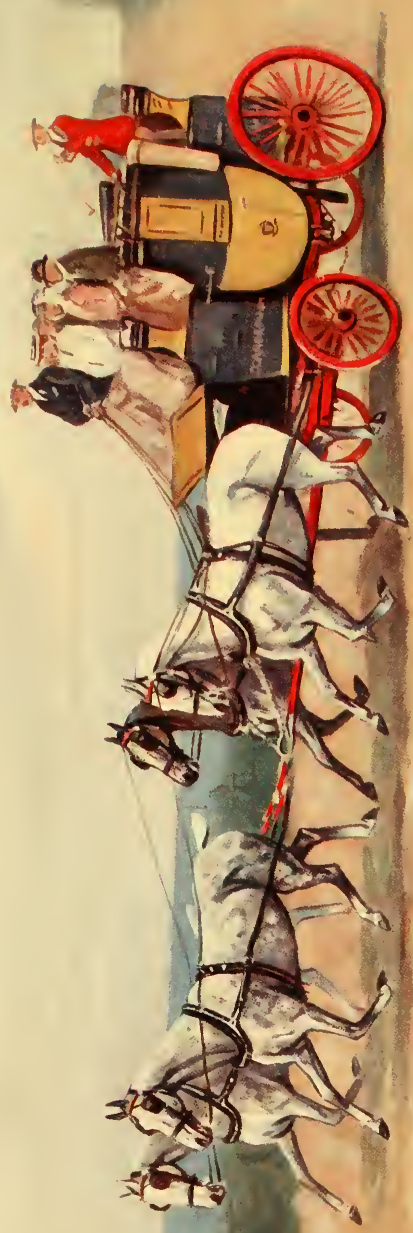

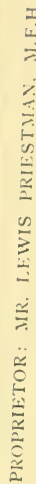

4

3

7

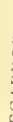

บ

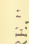

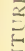

2

5 

Lord Lonsdale's reputation as a coachman has always stood high, and his splendidly equipped procession of carriages is one of the most striking features of the Leicestershire race meetings. In these days of dull monotony, the gay livery of the yellow-jacketed postilions, with same Lowther colouring for the four-wheel chariots, is very pleasing, brightening up the ordinary traffic of the country. Lord Lonsdale is one of the few who has the greater part of his carriage-work done by postilions, and it is a revival of a most interesting period in history. All the harness horses are matched pairs of thoroughbred-looking chestnuts with bang tails, and their appearance on the scene commands the attention of a royal procession. Years ago all his lordship's horses had to pass a weight-and-measure examination; to go under the $I_{5}$ hand 2 inch standard of height, and weigh not less than $9 \frac{1}{2}$ cwt. Lord Lonsdale's hunters, too, had to submit to the tape and standard. Not over 16 hands in height, not measuring less than 6 feet round the girth when in hard condition, not less than $8 \frac{3}{4}$ inches under the knee, were hard-and-fast lines insisted upon.

Lord Lonsdale's great driving feat against time in the year $189 \mathrm{I}$ is an interesting record in these days of Marathon coaching drives. It will be remembered that the Earl of Lonsdale and the Earl of Shrewsbury, the reputed best whips of the day, were matched for a hundred pounds a-side to drive twenty miles, the order of running being heats of five miles for a single horse, a pair, a team, and a postilion pair. When Lord Shrewsbury scratched, then Lord Lonsdale, sooner than abandon the match, which had attracted enormous attention, decided to drive against time. The first five miles behind War-paint, an ex-steeplechase horse harnessed to 
an American buggy, was accomplished in $13 \mathrm{~min}$. $29 \frac{1}{5}$ sec., the next stage of five miles behind two American trotters was covered in $\mathrm{I} 2 \mathrm{~min}$. $5 \mathrm{I}_{5}^{2} \mathrm{sec}$. The team of thoroughbred leaders, and a pair of fire engine-horses for wheelers, galloped the course in I $_{5}$ min. $9 \frac{2}{5}$ secs., which was very good considering the weight of the vehicle and the heavy state of the road. For the last five miles Lord Lonsdale got on the back of a beautiful weight-carrying hunter, harnessed by the side of a thoroughbred, and they whisked the four-wheel conveyance over the fivemile course in I3 min. $\frac{1}{8} \mathrm{sec}$. The full twenty miles, including all stoppages, was covered in the remarkable time of $56 \mathrm{~min} .55^{4}$ secs., and the achievement was greeted with loud and prolonged cheering.

For many years coaching competitions at the Hurlingham and Ranelagh clubs have been attractive features in the summer programmes. The courses arranged on the green sward show to advantage the fine equipages, and the tests bring out the capabilities of the coachmen as well as the handiness of the teams. The rules for such a competition over a measured 200 yards course are: the first Ioo yards to be zigzag between pairs of barrels I 2 feet apart and I6 yards distant from each other; the second Ioo yards straight between a line of pegs placed at intervals 6 feet 6 inches apart. Full marks are twenty, from which for every obstacle knocked down two points are deducted, and for each obstacle touched one point. In the case of a tie, the coach that does the course in the best time is adjudged the winner. A good time, I min. 7 secs., over the Ranelagh course was made by Sir Savile Crossley, who brought his team along at a gallop without touching barrel or peg.

The management of the International Horse 
Show introduced a new and attractive contest styled "The Coaching Marathon," from Hampton Court to Olympia. The coaches, leaving Hampton Court, cover a specified route, reaching Olympia within an hour and a half, the judges considering the condition in which the horses arrive. Such a contest is very popular, and should do much to make driving attractive.

Any evening during August the arrival of the "Venture" coach is awaited with keen interest by a crowd gathered around the steps of the Grand Hotel at Scarborough. Punctuality is one of the points of good coachmanship, coming next to safety and dispatch, the "Venture" owned and driven by Mr. Lewis Priestman, master of the Braes of Derwent hounds, being the best of time-keepers. On the tick of half-past six the silvery notes of the "yard of tin" may be heard echoing down the narrow crowded streets, as with rhythmical trot the team of sporting greys swing into view and pull up opposite the fine hotel, looking out across the Bay of Scarborough. The last stage in, of eight miles covered in fifty minutes up and down hills, is a severe one, and the team stand with their necks stretched and tails quivering, glad to catch the cool

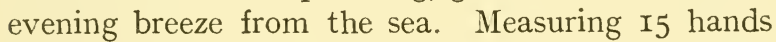
2 and 3 inches, they look exactly the stamp of horse for work, quick and active hunters, built close to the ground, with good round feet. Compact horses always look well in harness, doing their work easier than leggy ones, and are pleasanter to drive. The team of greys, it was evident, had done a spell of work together; they looked very level, and their action was equal, the wheelers having rather more substance than the leaders.

As might be expected, a coach owned and driven 
by a master of hounds is sure to be turned out in the most workmanlike style possible. Of the four teams that do the daily journeys between Scarborough and Bridlington, the distance being twenty miles each way, most of the horses are of hunter stamp. Half the pleasure of coaching consists in sitting behind fresh young horses in the full vigour of life, free-goers that put heart into their work, the teams driven by Mr. Lewis Priestman being five and six year old, with the advantage of a season's condition and hard corn. On occasions when, owing to accident and indisposition, it was necessary to make up the team with a hireling, the change was at once apparent. A hireling is nearly always a seasoned, aged horse, a good, honest worker, no doubt, ready to slog along in his own slave-like way, but a most dreary, uninteresting horse to sit behind. A coach team of hirelings, all nodding their heads to a different tune, would be even less exhilarating than riding stale hunters. The teams that work the "Venture" coach match well in colour, stamp, and action, looking "varry like the road"; they at once pleased the eye as a whole, without being extravagant in any detail.

Yorkshire is a county of critics where horse-flesh is concerned, and the appointment of the "Venture" coach, with its black and yellow body, scarlet wheels, and blue cushions, delighted the eye of the experts there to see the departure and arrival each morning and evening. The harness with brass mountings was of the very best make and beautifully cleaned, the latter point being thoroughly characteristic of a hunting stable. Free from ornamentation, the badge of the Braes of Derwent hunt, in the shape of a fox's mask in brass on the bosses of bridles, just 
gave that sporting touch, together with scarlet headbands, carrying the colour through from the bars, pole, and wheels of the coach.

On a joyous, bright morning in August, with a refreshing breeze blowing off the sea, we were honoured with the box-seat on the "Venture" coach. The four greys, the first team out, Mr. Lewis Priestman threaded skilfully through the narrow streets of Scarborough, thronged with every description of traffic. Walter, the guard, had a watchful eye in the rear, quite necessary in these days of rapid motors, and his musical accompaniment on the horn was the signal to clear the road for the most popular institution to be found anywhere in Yorkshire. Leaving the town, hill-climbing begins at once, the coach travelling smoothly as the team were sprung up the short gradients; Mr. G. Burgess, the manager, working the brake, besides being in readiness to take the reins for the second stage from Filey.

The extensive view on the right is a rolling panorama of agricultural land, mapped out on the hillside with a tracery of fences, a district hunted by Lord Middleton's hounds. To the left is the sea, three hundred feet or more below the rugged cliffs; and melting away behind us could be seen the bold outline of Scarborough's Castle Hill, compared by those who know it to the Rock at Gibraltar. Hardly a mile of the eight into Filey is on level going, and Yorkshire has added charms when viewed from the top of a coach. A sharp descent into Filey gives a sight of the famous Brigg, and the narrow streets with their sharp turns put to the test all the skill of a practised whip.

The fresh team awaiting us were four bright bays, not quite so level in appearance as the greys, 
but a useful lot to do the five miles each way in and out to the Dotrill at Reighton, a lonely wayside inn. The third team of dark browns and a chestnut were bigger, heavier horses with the best of manners, for the most difficult driving stage into Bridlington. Going through the town it was easy to imagine that Pandemonium had been let loose, a whirlpool of donkeys with bells on them, carrying a party of noisy trippers, being most disconcerting, but the leaders went straight ahead, oblivious of any kind of road nuisance. This dark brown team were more of a harness stamp than any of the others, higher on the leg, and with taking action, the offside chestnut wheeler being the only hunter of the party. For the return journey after luncheon, they were in readiness again, and it was a revelation to find that, in spite of incessant afternoon motor traffic in both directions, we accomplished the journey with safety and dispatch. A new team of chestnut leaders and bright bay wheelers were in waiting at Filey to do the heavy stage of hill work back to Scarborough. The leaders were both fifteen-stone hunters, a very sporting pair rattling the bars gaily as they danced along in front of the powerful wheelers, who had a lot of collar-work steadying the coach down the steep inclines near Cayton. To sit behind such a team was most interesting, for on a journey we seem to realise the character and temperament of each horse, as with light hearts they swing the coach along, performing their work with that generous spirit so characteristic of a good hunter with hounds.

The view lit up by the setting sun was magnificent in colour and boldness, an ever-changing effect of light and cloud that almost defies description. The music of Walter's horn did seem to enliven the 
last stage of the forty-mile journey; and as we arrived on the tick of time at the Grand Hotel, Scarborough, there was the welcome thought of dinner, and the usual crowd of sightseers to look round the team which had changed places with the greys that started out in the morning.

That day by day these summer road coaches have their complement of passengers to travel by them, at the regulation fare of threepence a mile, augurs well for the continued love among Englishmen of fresh air and open scenery.

The coaching fraternity can boast it is one of few sports not to be hindered by weather, for, supposing it rains from morning to night, the philosophical traveller remarks, " Thank goodness, there is no dust or flies, and very few motors about!" After all, as the poet sang-

"It is the hard grey weather that makes hardy Englishmen."

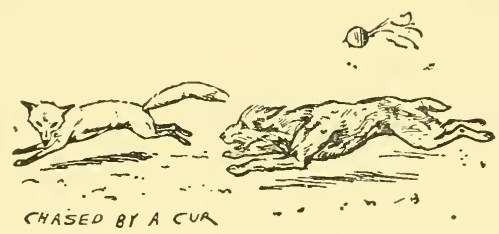




\section{CHAPTER XIII}

\section{YORKSHIRE HUNTERS AND HOUNDS}

A day with Mr. J. H. S. Fullerton hunting the Badsworth hounds-

Badsworth Finisher-The meet at Robin Hood Well-The bag for the season-Lord Middleton's country-The late Sir Tatton Sykes -The kennels at Birdsall-Tom Bishopp-The leading strains of hounds and celebrities in kennel-Lord Middleton's stables and hunt horses-Hunter sires at Birdsall-Hunter brood mares with sixty years' pedigrees-Mr. Arthur Wilson, master of the Holderness - The winners at Peterborough in 1902-Holderness Handel and Sanguine.

"Oh, shadow of glory,

Dim image of war;

But the chase hath a glory,

Her hero a star."

Through the kind invitation of Mr. J. H. S. Fullerton, when master of the Badsworth, we can claim to have seen one day's hunting with a Yorkshire pack in the spring of Igor. A deep fall of snow during the night made the prospect of hunting very doubtful, but the sun worked a quick change, so that in a few hours the valleys were in flood. The meet was at Robin Hood Well, on the Great North Road, six miles north of Doncaster, and we rode six miles to covert from the kennels at Wentbridge with Mr. Fullerton, who was hunting the lady pack of eighteen and a half couple. The kennel was considerably strengthened with Belvoir and Brocklesby blood; a very nice dog, Finisher by Belvoir Dexter, being amongst those that won honours at Peterborough for Mr. Fullerton.

At the meet, intelligence of an outlier reached the master, seen an hour previously near the quarry 
in Skelbrooke Park. Hounds quickly had him away jumping over the wall, running across the Park past the Church and the Hall, with Mrs. Fullerton doing the duties of field-master to keep a hardriding field in check. Scent was very catchy off the grass, and Mr. Fullerton had to help hounds as they hunted steadily in a line with the Hull and Barnsley Railway, where the going was terribly deep and holding. Checking at the Great Northern Railway Bridge, they cast themselves and hit off the line near the Mainpole brook, running with tuneful chorus to Mr. Finlay's garden at Skellow,

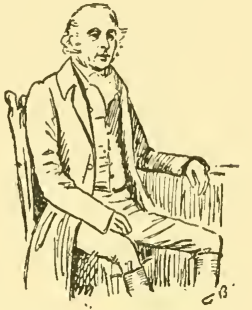

Sir Tatton Sykes. where they checked. A cast over the road set them right, and they hunted slowly into Owston Park, going on through Burghwallis Wood to the limestone country beyond, where all trace of scent vanished, after a patient hunt of over an hour, which brought out much good hound work. For several years Mr. Fullerton hunted from Grantham, and rode many a good run with Tom Firr, Frank Gillard, and George Gillson, being one of the foremost riders of that time. During this particular season with the Badsworth, Mr. Fullerton killed thirty-nine and a half brace of foxes, the dog-pack having the best of the luck, averaging a fox every time they went out.

The opportunity to spend a day at Birdsall and see the sights of a splendid hunting establishment, over which the present and ninth Lord Middleton has presided for the past thirty-two years, is one of the I 908 pleasant recollections of a holiday spent in Yorkshire. The very air breathes of sport and savours of tradition, the rolling panorama of moor, woods, hills, and winding rivers presenting a varied 
charm and wildness of scene so befitting a setting for the chase. Those who know Yorkshire, have pronounced the area of some forty miles hunted by Lord Middleton's hounds, some of the most sporting to be found anywhere in England. Purely agricultural, a large portion consists of wolds, while the remainder is low-lying vales with heavily-wooded hills, admirably adapted to bring out the hunting qualities of a pack. The present occupants of the benches are descendants of hounds hunted by Sir Tatton Sykes, who was a great breeder of thoroughbred stock, and they have been improved during the past fifty years by Lord Middleton and his father before him. To-day there are few hunting establishments where hunters or hounds can boast longer or stouter pedigrees, and in both departments of the chase there is much to see that will interest those who admire the highly-bred animal, for, after generations of careful selection, a type has been established both in the stable and in the kennel.

The natural order of things is to begin with the hounds, on whose excellence the fame of a hunt depends, and Tom Bishopp spared no trouble to show us the pick of some fifty-seven couple. Bred for good looks and work, it is a kennel full of quality matched for size and colour, a hound nearer the 23-inch standard of height appearing to be the type favoured on the flags at Birdsall. The kennels are about as complete in their arrangements as it is possible to imagine, and were designed about fifty years ago by the late Lord Middleton. The handsome block, with its roomy day yards and golden fox surmounting the central tower, are about a quarter of a mile from Birdsall House, Lord Middleton's home, which stands near an extensive range of old-fashioned stabling. The plan of the kennels has 
been adapted by the Cottesmore and Hertfordshire hunts, the covered-in passage with top lights being a most convenient accessory in which to show the hounds in bad weather. As it happened while we were seeing the hounds, a rattling thunderstorm broke over the kennels, driving us out of the day yards to shelter, the artillery of hail on the glass roof being very disconcerting for hounds.

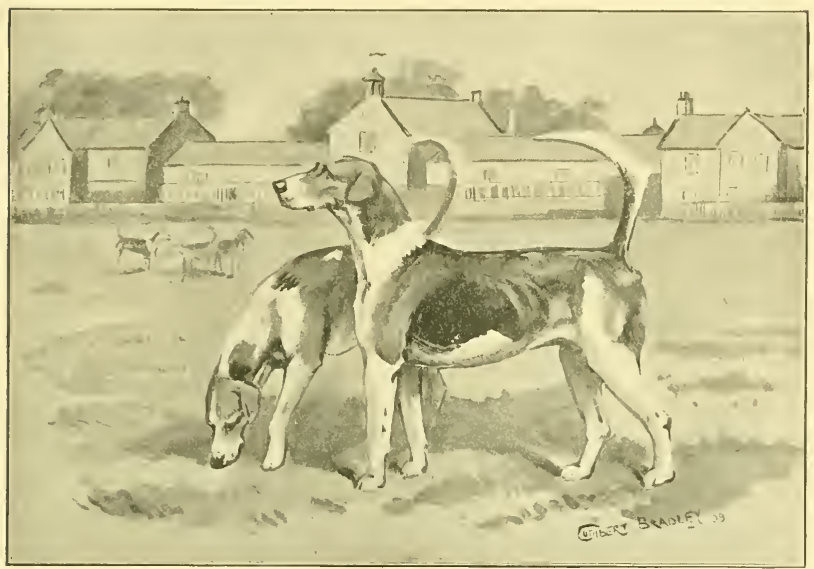

Lord Middleton's Kennels.

Tom Bishopp, who came to Lord Middleton as huntsman from the Quorn in Igo8, is no stranger to Yorkshire, starting life as a whipper-in to his present kennel, passing on to the Bramham Moor.

Taking the hounds in order of seniority the veterans came first for inspection, the Belvoir type and colouring at once catching the eye, for the blood of that kennel mingled with Brocklesby is responsible for the foundation of much present-day success generally. When Tom Bishopp put forward Dexter ('02), it was plain to see that he regarded 
the old hound in the light of a huntsman's friend, and he was described as an extraordinary dog in his work, one of the Solons of the pack always to be relied upon to find a fox. Quite a Belvoir sort, he was not so handsome as his sire Belvoir Dexter ('95), though he showed a strong family likeness, especially in the brainy appearance of the head. On the side of his dam, Woodbine ('99), he inherited great working qualities from Grafton Woodman, who went down to posterity as the tap-root of much excellence. Strange to say, Bishopp bred and entered Woodman when huntsman to the Grafton, and this hound gave the Belvoir an excellent outcross, which resulted in the successive line of Wonder ('98), Warlaby ('o4), Weaver ('o6), Vulcan ('o7), and Wizard ('o9). Referring to the pedigree of Grafton Woodman ('88), a great hound in his work, we found that his dam was by Belvoir Founder ('86), who was one of the three top sires at the ducal kennel, the other two being Weathergauge and Finder, all helping to improve and build up many packs. Lord Middleton's Dexter had not the length of his sire or the general scope, but he proved a good-wearing hound, used by masters of hounds in the north, his name also figuring in the I9o8 Meynell entry with a strong litter. At home Dexter was represented by a worthy son, Deacon ('05), showing plenty of stuff and quality, a mediumsized compact hound that sired good stock for other kennels. Derwent was another sire of the same year by Dexter, a bigger-framed hound, but unfortunately lame from the result of accident. Just the type of hound for Yorkshire describes Viceroy ('o3), a son of Belvoir Villager ('97), a nice tan dog with black on his ribs, standing well on short legs. Viceroy sired many good working hounds in the pack, 
and, like his sire, was a determined sort in chase, besides being a good-looking one in kennel.

The line of the famous Freshman ('95), who was by Pytchley Freshman, was represented by Fraisthorpe ('O2), a beautiful dog, and Friday ('OI), an upstanding hound with a wonderful character, though not overdone with bone. Freshman was used with success by the Cottesmore, and a few seasons ago a son of his, called Freeman, was pronounced by Arthur Thatcher to be the best foxhound he ever saw in chase. Mr. Wharton, master of the Cleveland, was another who dipped into the Freshman blood, and it is helpful in any part of a run. When Stalwart ('o7) came in we liked him as well as anything put forward on the flags; he was a son of Steadfast ('04), who was a son of Belvoir Stormer ('99), and in the young hound there was the elegance of neck and shoulders so distinguishing a feature of Stormer, who brought in the blood of Grove Harkaway, and introduced into the Belvoir kennel the black ticking on the legs and chest. Stalwart was great on the line of a fox, a lively hound in chase, and all liberty on the flags; he came under the $23 \frac{1}{2}$-inch standard, just the type for the wolds and hill country. The dam of Stalwart was Frolic ('02), a daughter of Freshman, so that in his veins coursed some of the choicest blood to be found in the kennel. Another nice-turned dog by Belvoir Stormer was Student ('05), whose son Stormer was placed first in the Igo8 entry, the second position being occupied by Vagrant, son of Belvoir Vagabond ('99), who was one of the most valuable sires put forward by the ducal kennel during the past fifteen years. From the foregoing remarks it will be seen that Lord Middleton's is a kennel to go to for blood and improvement, combining as it does 
the strains of so many notable sorts, the pedigrees of its hounds being most fascinating to follow.

The bitches we only had time to glance through collectively, and they were beautiful in type, with good bone, necks, and shoulders, the kennel owing its fame to their excellence. One of the celebrities amongst the matrons was Daisy ('o3), a daughter of Belvoir Dasher (Igoo), by many considered to be Belvoir Dexter's best son; the dam of Daisy was Frugal ('98), a daughter of Freshman, so she boasts the best of breeding. The fame of Daisy is likely to be perpetuated for many a year to come with five and a half couple to represent her in the kennel, including the top bitch at Birdsall named Wary ('o7), who is one of a remarkable litter of four couple by Grafton Waggoner. These ladies do drive, so we heard, and their lines are indicative of speed, displaying on the flags that nippiness of movement so characteristic of the thoroughbred foxhound.

A second pleasure awaited us when turning to the stables to see Lord Middleton's hunt horses, for they present a stud of exceptional merit, bred, as they are, all to a type. Very few stables in England can show the best part of fifty hunters bearing such a strong family likeness, and this is explained by the fact that the brood mares at Birdsall are descended from mares in the stud whose pedigrees have been kept as carefully as those of the hounds for the past sixty years. The late Lord Middleton founded the stud, and to-day the present Viscount has a store of bunter brood mares, descended from hunters who have all proved their worth in the field. Sired by thoroughbred horses of the right type to do good amongst hunting mares, a thoroughbred stamp of hunter has been established, combining substance with quality. Such a home-bred 
stud as that to be seen at Birdsall is an object-lesson of the good hunter-breeding has been to the country when carried out on the scientific principles adopted by two Lord Middletons during a mastership of over fifty years. It is said that the pony type was the original pattern aimed at in the stable, and to-day it is noticeable that a medium-sized hunter is in favour, measuring rather under I 6 hands, a short-legged, active, blood-horse, excellent in back and shoulders, with depth through the heart. Such a type of hunter is adapted for any country, possessing pace and stamina, power of hocks, and second thighs, the best conveyance the heart of man could desire. Bays, browns, and chestnuts are the predominating colours, all having manes, and semibang tails, which adds to the evenness of appearance noticeable throughout the stud.

Amongst the many notable thoroughbred sires which have been kept at Birdsall by the Lord Middletons for the use of the farmers and the puppywalkers, are many which completed a distinguished career on the turf, and proved their stamina by winning races in their fourth year of training. Lord Middleton's hunter sires include the names of Peppermint by Camballo, a winner at the Hunter's Improvement Society Show; Gordon by Hermit, dam by Young Melbourne; Sherbrooks by Dutch Skater, dam Verderer by King Tom; Red Eagle by Thurio, dam Tranquillity by Venison, who raced up to his sixth year, and afterwards was awarded three royal premiums; Wales by Belgrave, dam Victoria ; Cardonald by Carronald, a descendant of Stockwell; and The Dempster.

Quite twenty in the stable were by Gordon, and had the character for being the best of hunters, able to gallop up and down hill and stay all day. 
Red Eagle is another whose stock we admired, beautifully turned hunters with good bone measurement, and the young Wales are distinguishable for the strength of their jumping quarters. Many of the brood mares can trace back in descent to the old original Yorkshire pack-horses of the last century, and the dash of pony blood in their veins gives that extra stamina so valuable for the hunting field.

If time had allowed we should have liked the opportunity to have seen Lord Middleton's stud farm, where fourteen shire stallions are kept, and a choice lot of brood mares, many of which are wellknown winners in the show ring. A short day only gave the opportunity to see but a sample of the triumphs of breeding to be found at Birdsall, but it was long enough to appreciate a splendid hunting establishment, and realise that Yorkshire is still one of the foremost counties to which we may look for our supply of horses.

In the summer of I902, at the invitation of the late Mr. Arthur Wilson of Tranby Croft, for so many years master of the Holderness Hunt, we went to that kennel to paint the portraits of two hounds which won honours at Peterborough Hound Show. At that time Walter Metcalf was huntsman, the kennels being a short distance from Beverley, whose fine Minster invites inspection. The hounds we went to interview were Handel, a niceturned dog, rather back at the knees, by Belvoir Handel; he won in couples with Dasher in the unentered class at Peterborough 1902, and again as the best young dog-hound in the show. Handel was of great service to his kennel as a sire, his name coming into pedigrees of many good hounds in the north. The other hound that we painted was 
Sanguine, champion bitch at the Peterborough Show, I902, an all-black bitch edged with tan and white, colouring rather typical of the Holderness kennel. Sanguine stood well on the best of feet and legs, her neck and shoulders left nothing to be desired, but the arch in her back looked rather like a "roach." The success was a great triumph for Yorkshire, which has always stood high in the estimation of those who love a horse or a hound.

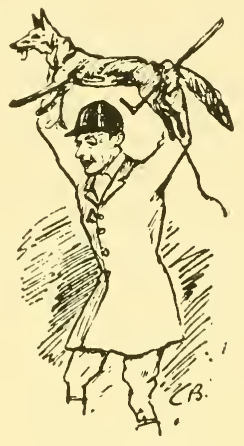

Who-whoop! 


\section{CHAPTER XIV}

\section{HUNTING WITH THE COTTESMORE AND ARTHUR THATCHER}

The old and the new school of hunting-Tom Firr's opinion on a trying day's sport for the huntsman-Mr. Evan Hanbury-Arthur Thatcher the whipper-in, then huntsman to Essex Union-Good advice to whipper-in and huntsman-The Cottesmore country described-A country to make a pack of hounds-Good old county families-The Earl of Ancaster-Sir Gilbert Heathcote's mastership-Large landowners-Launde Wood-Prior's Coppice-Ranksborough GorseArthur Thatcher's best hunting run-Belvoir and Cottesmore compared-Two good hunts in December 1903-Beau Brummell and buff tops-A good hunt through Morcary into Lincolnshire-To ground by Little Bytham-A long continuous hunt-The Cottesmore and Fitzwilliam packs join and kill-A great day's sport in the Manton district-A distinguished Cold Overton field-Over the Whissendine brook-A wild Lincolnshire woodland fox "brushed" by Thatcher-Tom Firr assists Thatcher in a hunt-A tribute to Arthur Thatcher's worth.

"What! four of us only! are these the survivors

Of all that rode gaily from Ranksboro' ridge?

I hear the faint splash of a few hardy divers,

The rest are in hopeless research of a bridge ;

Va victis ! the way of the world and the winners!

Do we ne'er ride away from a friend in distress?

Alas! we are anti-Samaritan sinners,

And steaming past Stapleford, onward we press."

- IV. Bromley Davenport, M.P.

A BRILliant era of sport distinguished Mr. Evan Hanbury's seven years' mastership of the Cottesmore, I900-I907, with Arthur Thatcher, one of the quickest of the new school of huntsmen. It has been said of the grass countries that pace is the elixir of the chase, and Leicestershire cannot be fully appreciated unless the hunt travels fast enough. 
With each generation of sportsmen many changes must necessarily come about to suit the temperament of the age, and though hunting is a most conservative sport, so that those who have ridden longest resent any sort of innovation or change, yet a forward and progressive tendency is necessary to preserve its vitality, and bring a timehonoured institution right up to date. The older school of sportsmen, who rode with the celebrated huntsmen of the last generation, and enjoyed the best years of their life, during long tenures of office, under one exponent of the noble science, cannot be excepted to welcome with enthusiasm a new constellation of talent, whose brilliancy promises to eclipse the

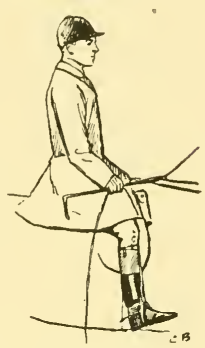

Arthur Thatcher. glamour that surrounds the doings of the past. Time alone must decide the merits of each generation when weighed in the balance, but those who have hunted fifteen or twenty seasons can claim to have seen two different systems of hunting the fox in Leicestershire, and will not be too old or bigoted to admit that the best of sport has been enjoyed with each.

Tom Firr has been singled out as the model of a Leicestershire huntsman, and even in this rapid age, when the ideals of yesterday are so quickly replaced by the triumphs of the hour, the great huntsman's name is mentioned as a standard of comparison for those following in his footsteps. The reason that Tom Firr's memory survives his generation is because his methods were in advance of the age, and he was one of the very few whose nerve never failed, riding at the age of fifty-eight, in his last season at Quorn, as brilliantly as when he first joined the pack. 
Amongst the leading talent in the field to-day, both amongst gentlemen and professional huntsmen, there are many who received an inspiration from Tom Firr's finished performance, and modelled their plan of campaign on the same lines. Brain as well as nerve are the necessary attributes for the huntsman to a pack of hounds in a fashionable country, especially in these rapid times, when a day's sport is carried out at very high pressure. A Leicestershire field is always keenly competitive, but at the same time it is thoroughly appreciative, and a successful huntsman's popularity might be envied by a Prime Minister or an Archbishop. Of course Tom Firr, with years of experience behind him, was a master at the game, standing the severe test of criticism better than any man of his time, but even he confessed that the Quorn Fridays on a bad scenting day were the most trying, owing to the size and ardour of the crowd. He used to say that there was only time to make one cast when hounds checked, and if that did not come off, he had to take the smart bitches practically in his hand and lift them clear of the crowd. Possessing a marvellous instinct of the run of a fox, no one knew better when the exact moment had come to make a bold cast, although Tom Firr was one of those who believed in leaving hounds alone on every occasion possible.

For many years Mr. Hanbury hunted from Oakham, and was one of the leading division with the Leicestershire packs, a light weight who favoured a thoroughbred type of hunter, and donned silk on many occasions with success. Identified with the county of Rutland by marriage with Miss Gwendoline Finch, daughter of the late Mr. G. H. Finch of Burley - on - the - Hill by Oakham, Conservative 
member for Rutland nearly forty-five years, and latterly father of the House of Commons, Mr. Evan Hanbury's acceptance of the mastership was heralded with delight by all sections of the community, for it was no easy task to find a successor to Mr. W. Baird, whose long reign was remarkable for peace and consistently good sport. No hunt is better done than the Cottesmore, and the new master instituted a faster era of sport, with Arthur Thatcher recalled from the Essex Union.

Of Arthur Thatcher it was said by a writer signing himself "Vagabond" in Land and Water, October I9, I90I, who hunted with Mr. Fernie's: "Few huntsmen have risen so rapidly to fame as Thatcher, who comes of a family of huntsmen and whippers-in. What brought him to notice was his great opportunity in the year 1896, when he was twenty-six years old, after eight years' service as second whipper-in with Lord Middleton's and Mr. Fernie's hounds. His fine qualities as a horseman had become plain before then to observing eyes; the good horses on which Mr. Fernie mounts his men helped to perfect a natural aptitude, for no fence would stop him when he was wanted to turn hounds. It was, then, as a matter of course that he succeeded to the place of first whipper-in, which was vacated by the promotion of Kinch to be huntsman to the Atherstone. Early in the season Charles Isaac, Mr. Fernie's huntsman, was laid by with an attack of pneumonia, and Thatcher was called upon to hunt the hounds. In spite of bad scent, absence of the master, and other difficulties, Thatcher showed excellent sport.

"In I 898 an opportunity offered for promotion with the Essex Union, and also for the gaining of additional experience. There is no doubt that a 
huntsman cannot perfect himself in the science of hunting if he only knows the grass countries. In the Essex Union there is some grass, but more plough, and much stiff woodlands. It is a country to learn in, but not one to break a huntsman's heart, for it is as a rule a good scenting plough. But if Thatcher learned from the Essex Union he also taught, for we have heard on good authority that he fairly revolutionised the style of riding in that country. The Essex Union became by force of example and emulation a flying country. Taken in this way it is probably safer, as it certainly is more enjoyable, to ride over. In his thirtieth year, the very prime of a man's hunting life, when he is not so young as to be likely to throw away his chances by rashness, nor so old that they have come too late, he found himself huntsman to the Cottesmore."

Then the writer, after seeing good sport with the Cottesmore and Arthur Thatcher, concludes: "The fame of the huntsman will no doubt draw crowds to the Cottesmore, but the wide pastures, the stiff fences, the steep hills, as well as the absolute necessity for a good horse and a stout heart, will probably, after all, reduce the crowds automatically within manageable compass. If we had a word of advice to offer, it would be that while a whipper-in, like a subaltern, should never think of danger, a huntsman, like a general, owes it as a duty to his followers to be gallant, but not rash."

Mr. Evan Hanbury mounted Arthur Thatcher in splendid style, on thoroughbred horses that had taken to jumping, as many as three a day being at his disposal on the Leicestershire side. Reviving memories of the horses he rode, Thatcher said: "I went two whole seasons without a single fall, and 
the best horse I ever rode was called Sir Bache, a strong, short-tailed bay. He never gave one fall in six seasons, and I now have his hoof mounted, which Mr. Hanbury gave me. Another fine performer was a mare called Nesta, sold for 370 gns. when Mr. Hanbury gave up the mastership. Socks, another of my favourite mounts, I bought for 270 gns. at the sale, and now hunt Mr. Fernie's hounds on him; he is a wonderful hunter. The following were all long-tailed blood horses: Mischief, Riversdale, Goodman, Johnny Lyons, Chinaman, Nesta, and Socks. Then I rode Snowflake, a grey bob-tailed horse, a very fine jumper, bought by the Hon. W. R. Wyndham; and Badger, a white-faced black horse, with a short tail, a clinking good hunter, bought by Mr. V. Hemery for I8o gns., when all the horses were dispersed.

"My best hounds in the field were Falstaff ('OI) by Lord Middleton's Freshman ('95), out of Fallacy ('97); he was quite the best hound in chase I have ever seen. Another good dog was Ambrose ('O3) by Brocklesby Augur ('9o) out of Captain Johnson's Amorous ('99); he was a clinker, so were Denmark and Dolphin, by Belvoir Dexter ('95) out of Songstress ('93)." As a whipper-in Thatcher gained much experience with Lord Middleton's hounds, so Falstaff breeding would be known to him.

The Cottesmore has always been regarded as one of the most desirable hunts from a social point of view, and it would be hard to find a better country in which to pursue the fox. It is not, therefore, surprising that all the élite of the fox-chase ride with the Cottesmore, for it is the one country of all others where a bold man on a good horse may enjoy himself. The bulk of the country lies in Rutland, one of the most conservative counties on 
the face of the map, with a large slice of Leicestershire grass country in the vale to the west of Oakham, and a wealth of wild woodland district on the eastern Lincolnshire boundary.

Hunting in the wooded districts either at Tilton on the Leicestershire side, or Morcary on the Lin-

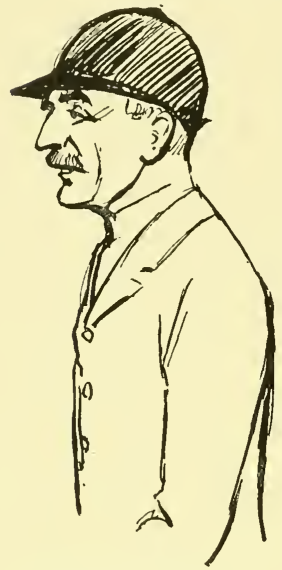

Mr. Evan Hanbury, M.F.H. colnshire side, where thick and sticky coverts are surrounded by old turf carrying a good scent, is a training in hunting craft, and the making of a pack of hounds. Free from the presence of the crowd, who never wander very far away from the grass, there is room for hounds to hunt a fox, and they take some catching on their own ground in these wild, wooded districts. As Mr. T. F. Dale remarks in his interesting book "Foxhunting in the Shires," "One of the reasons why the Cottesmore show such sport in their Tuesday country, is because they have a master and huntsman who know that no brilliancy in the open can result in good sport, without it rests on a foundation of hard work in the woods. Thatcher works his woods and kills plenty of cubs in the autumn, and the members of the bunt reap the reward in the winter."

When admiring the hounds to-day we must not forget the excellent work done by former huntsmen, William Neal and George Gillson, who laid the foundation on which others have been able to build. The foxes of the country are stout and wild, so that a pack must be able to hunt as well as race, for 
most of the coverts are strong woodland with wide areas of country between. But few gorse coverts exist, and no artificial earths, so that every variety of hunting, whether on the grass, plough, or in the woodland districts, is an opportunity to enjoy the chase under the most perfect conditions. A good scenting country, and sparsely populated, the pack are seen to great advantage in the open, and once clear of the woodland strongholds it is a congratulation to have a good horse under you! But a huntsman and his hounds must be quick, if they hope to handle a Cottesmore fox, and in Arthur Thatcher they had their match.

The Cottesmore country is one of county families, who give a reflected glory to the hunt which has flourished under their fostering care for the best part of two centuries. The past history of the pack is inseparably linked with the Noels, Lowthers, Trollopes, and Heathcotes, extensive land-owners in the hunt, who collectively have held masterships extending over nearly a hundred and fifty years.

Amongst owners of large estates, both in the Cottesmore and Belvoir countries, is the Earl of Ancaster, son of the late Sir Gilbert Heathcote, who held the Cottesmore mastership early in the last century, and had a fine stud of hunters under the care of the famous Dick Christian. It is interesting to note that when Sir Gilbert Heathcote's hunters were sold by Messrs. Tattersall in the summer of $\mathrm{I} 807$, one horse made 360 gns., three realised 3 Io gns. each, and two went at 300 gns., the remainder of the stud making high prices.

At this time the hounds were kennelled at Normanton Park and Stocken Hall, and later, when the Lowther family came into possession, they were 
kept at Cottesmore village, near Oakham, from which place they take their title.

The present Lord Ancaster residing at Grimsthorpe Castle, on the Lincolnshire side of the country, for many years was chairman of the Hunt Committee, and is one of the largest subscribers.

Normanton Park, by Stamford, is the residence of Lord and Lady Willoughby de Eresby, eldest son of the Earl of Ancaster, a keen politician, and a hard rider on his day. By Stamford the Marquis of Exeter owns a large slice of property, and from Burghley House with his own pack of hounds devotes much time, capital, and energy in the interests of the chase. There is good fox ground by Exton Park, the seat of the Earl of Gainsborough, head of the house of Noel, who founded the hunt sometime at the end of the eighteenth century. On the Leicestershire side of the country, a large property is owned by the Earl of Dysart at Buckminster Park, and Mr. John Gretton, the present Conservative member for Rutland, joins in at Stapleford Park, the nearest Cottesmore fixture for Melton. Then there is Lord Kesteven at Caswick Park in Lincolnshire, whose father, when Sir John Trollope, held a mastership, with such good neighbours in the interests of hunting as Colonel Birch Reynardson at Hollywell Hall, the Earl of Lindsey at Uffington, Mr. Handley, the Squire of Clipsham, and Mr. C. H. B. Hesketh, the new owner of Stocken Hall. Nearer Oakham, there is Burley-on-the-Hill, owned by the Finch family; Sir Arthur Fludyer, owner of a large property and Wardley Wood; Captain Dawson at Launde Abbey, Colonel Palmer of Witchcote, Mr. Lauderdale Duncan at Knossington, Mr. Robert Heathcote at Manton and Lobthorpe. 
If we had to name an ideal covert in the Cottesmore country, opinion might be divided between Launde Wood or Prior's Coppice, from both of which many a history-making run has resulted, for, just the right size, they are always sure finds, and surrounded by grand country of quick-scenting grass, hounds generally get away on the best of terms with their fox.

Of the gorse coverts, Ranksborough, which stands out on a hillside in the vale by Oakham, sets the seal of approval on any day's sport, and is foxground that seldom fails to supply a pilot who may lead the way across a line of Leicestershire grass with fair hunting fences, and never so much as a field of plough in the view. The reverse is the case directly hounds cross over to the east side of the Great

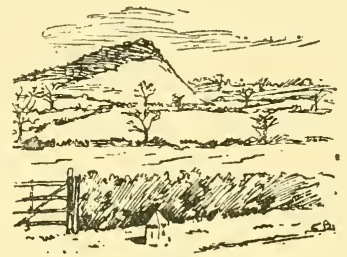

Ranksborough Gorse. North Road, for a continuous chain of strong forest is surrounded by a desolate country of alternate grass and plough, which rides deep in a wet time, and retaining a scent, provides the best of sport for those who appreciate good hound work and steady hunting.

"One of the best hunting runs I ever saw in my life, was hunting the Cottesmore on Boxing Day, December 26, I902," said Arthur Thatcher, selecting one from many which were quite as good. "We found at Oakham Pastures, rode by Prior's Coppice on the right, ran close up to Launde Park Wood, and turned to the left through Wardley by Uppingham, leaving Wakley village on the right, by the two Luffenhams, and killed him in the middle of the road at Tixover. It was a great performance 
on the part of hounds, and we did not draw again."

Of memorable days' sport seen with the Cottesmore and Arthur Thatcher, the diary contains many against which is the mark of excellence, for he was always cheery and keen, both of which are sterling qualities in a huntsman, putting a field at once on the best of terms with the day's sport. Idolised by those able to ride up to the pack, Thatcher managed also to give the tail end of the hunt the best of fun. A horseman beautifully balanced and possessing fine hands, big fences were jumped with consummate ease, and Thatcher was one of those who seldom had a first whip riding at his elbow. Both methods would, however, appear to be equally successful in furthering sport, for other Leicestershire huntsmen nearly always ride with their first lieutenant close at hand. Another contrast between leading Leicestershire packs is that the Belvoir staff wear the palest of tops, the Cottesmore favouring the dark mahogany colour. It is recorded in history, that Beau Brummell, the great dandy of the last century, on the occasion of a visit to the sixth Duke of Rutland, introduced the fashion of wearing pale buff tops, the tint of a buff Orpington's egg.

The entry of two days' sport seen December I903, recalls the lawn meet at Edmonthorpe Hall, the residence of Victoria, Countess of Yarborough, and Mr. J. Maunsell Richardson. In the absence of the master, the command was taken by Mr. W. Baird, the ex-master, and the first order was for Woodwell Head. Notwithstanding the fact that the Belvoir had twice on the previous day run through the covert, a fox was soon astir, leading the way to Gunby Gorse, where hounds overran 
the line. Thatcher made a cast, but scent being cold, no further good resulted. Later from Ashwell Spinney a splendid hunt was seen, though the pilot ran rather a twisty course, heading for Whissendine, over the brook for Stapleford domains. Sticking well to him through the coverts in the park, they drove him back past Wymondham Grammar School, and finished a good run in the park by Edmonthorpe.

On the following Saturday, the Igth, after meeting at Beaumont Chase, Thatcher put two good hunts to his credit, hounds crowning each gallop with a kill in the open. The first was from Stoke End, and the pilot failed to make his point in the Uppingham district, where hounds rolled him over after a short, sharp burst. Starting again at Wardley Wood, they ran a fox by Horninghold Spinneys, back through Allexton Wood to Ridlington. Bearing for Ayston Spinney, he made his last effort to reach Nevill Holt, but was so dead beat that hounds ran into him after an hour and fifty minutes-a fine performance on the part of huntsman and hounds, making a hard day for horses.

Sport that deserves the red letter in the hunting diary was seen on Thursday, November 30, I905, when a distinguished following met the Cottesmore at Thistleton village. It was a typical hunting morning, still and grey, the southerly wind bringing a scent, hounds scoring a four-and-a-half-mile point into the wilds of Lincolnshire, seldom ridden by the Leicestershire division.

An outlier jumped up out of a field of roots close to the village, and with hounds snapping at his brush raced for dear life to a well-known culvert under the railway, by Little Bytham Station, near the main line between Grantham and London. The 
ride was across a wild, untrimmed country, with spongy grass land, innocent of drainage or high cultivation. Crossing the Great North Road, hounds and Arthur Thatcher disappeared in the dark recesses of that huge oak forest, Morcary Wood. We took the line of grass outside, riding at best pace for a mile and a half down the side of covert, straining an ear to catch the cry of hounds, whose line could be judged by the pigeons rising from the tree tops. Scent was too good and Thatcher too quick to allow of the hunted one shaking off his pursuers, but when the huntsman's thoroughbred bay horse emerged from the thicket, he looked as if he had taken a bath in liquid mud. The depth of these rides is proverbial, and how the horse could have come the pace down through the covert and kept on his legs, was little short of miraculous. However, the pack were running with a glorious cry, and had their fox straight as an arrow down wind over the rough grass by Stocken Hall, away for Little Haw Wood. For nearly the whole of the journey there is hardly a sign of any habitation, a wild sporting country such as our forefathers loved, with nothing more formidable than a roving bullock to head a fox in his flight. Such a district is never frequented with runners or sightseers, like the fashionable areas, and hounds must hunt for themselves, with little or no chance of the telegraph department being forward to give them a lift. Finding the last-named covert was no place of safety, Thatcher's electrifying cheer as he topped over the fence and got a view was good to hear! For a mile or more across a stony waste of bad scenting country they persevered, and a good sporting gallop of nearly forty minutes in holding going, ended with a mark to ground in an impregnable 
drain under the railway near to Little Bytham Station. Mr. J. Maunsell Richardson, on a bangtailed, thoroughbred-looking bay horse, was first up, and, riding forward, endeavoured to gain intelligence of the hunted fox from the villagers who came flocking out. The field included the master and Mrs. Evan Hanbury, Miss Finch, the Duchess of Newcastle, riding a short-tailed, strong, darkbrown horse, the Duke and Duchess of Sutherland, Victoria, Countess of Yarborough, Mary, Lady Gerard, Lord Gerard, Lord Alistar St. Clair, Lady Angela Forbes, the Hon. Charles Fitzwilliam, the Hon. Francis Lambton, Mr. A. V. Pryor, Mr. Herbert Gosling, Colonel Blair, Captain E. C. Clayton, Major Hughes Onslow, Captain Burns Hartopp, Major Milner, Mr. and Mrs. George

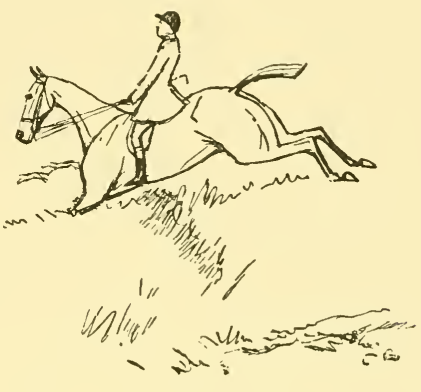

Arthur Thatcher.

Coats, Mr. H. R. Finch, Captain Noel, Miss Nailor, Mr. P. Evans Freke, Mrs. R. Ellison, Mr. Guy Fenwick, Mr. S. P. Bouverie, Captain Adkins, Mr. W. H. Pearson, Miss Sybil Knox, Mr. P. O. and Miss Chichester, Mr. Julian and Miss Tryon, Mr. G. Hunt, Mr. T. E. Robarts, Colonel Grenfell, Mr. E. Saville, Major Parker, Captain Vickerman, Captain Featherstonhaugh, Mr. C. S. Newton, Mr. Greville Clayton, Mr. V. Hemery, Captain Steeds, Mr. Frank Chaplin, Mr. Vere Chaplin, Mr. Noel Newton, and, top of the farmer division, Merry from Clipsham, the son of a famous stage-coach driver.

During December I905 we find it recorded that the Cottesmore had a week of continuous good 
sport, in spite of threatening frost and fog. After meeting at Stretton village, they had a tremendous hunt of nearly three hours' duration and were unlucky not to kill; evidently changing foxes, for the pace at times was so severe one could not have stood up before them. Starting at Tunnely Wood, they passed through the great forest of Morcary, a good line to Woodwell Head, which swarmed with foxes, back again to Gunby Gorse, another stronghold, through Hardy's Plantation, on to Beaumont Wood, away for the big coverts by Greetham, where hounds were stopped at dusk.

A memorable day's sport came within the same week, when they met at Witchley Warren by Stamford, Mr. George Fitzwilliam's hounds meeting close by at Burghley House, the seat of the Marquis of Exeter. The two packs joined in a covert known as Horn Stacks, and, getting away together, ran for an hour, killing their fox in company on the old race-course by Stamford. Mr. Evan Hanbury was in command of the Cottesmore, but the master of the Fitzwilliam was not out. Arthur Thatcher and Will Barnard hunted the combined pack by turns, and Thatcher relates, "It was my last turn getting close at him, catching him in some old ruins; so I cut the fox up."

After the hunt the combined pack was taken to Wothope ruins, and divided through a gateway. On the Saturday of the same week, after meeting at Beaumont Chase, hounds ran from Stoke End through Stockarton Wood and Merevale Holt to Medbourne by Mr. Fernie's kennels. The field out included the master and Mrs. Evan Hanbury, Mrs. Asquith, the Earl of Lonsdale, the Earl of Kerry, Lord Manners, Sir Henry Jervoise, Sir Bache Cunard, and Mr. W. Baird. 
Coming to a good day January 8, I906, after a stop for frost, Thatcher had the dog pack out at Luffenham, where a small field to meet them included, besides the master, the Duchess of Newcastle, Lord Gerard, Colonel Brocklehurst, the Marquis of Exeter, Mr. Herbert Gosling, and Mr. A. L. Duncan. The first spin was with a heath country fox who travelled across the Edith Weston Valley to Ketton, where scent gave out in the stone-pit district. A better fox was forthcoming from Glaston Gorse, some two miles from Uppingham, and, taking a very wide circle, hounds ran with great dash in the direction of Manton Gorse, round by Wing, over the Pilton lordship, nearly to Lyndon. The line is a stiff one, the going heavy, and the hilly nature of the country was responsible for a considerable amount of grief amongst the following. Coming back with a wide sweep up the valley past Manton village, they raced up to their fox before he could crawl into the gorse, and killed him.

Stirring sport marked I906-7, the final season of Mr. Evan Hanbury's mastership, though Arthur Thatcher for many weeks was on the sick-list, and hounds were hunted by the first whipper-in, Jack Boore. During December a large field from Oakham, Melton, and Market Harborough met the Cottesmore at Cold Overton; amongst those out being the master, and Mrs. Evan Hanbury, Miss Evan Hanbury, Victoria, Countess of Yarborough, and Mr. J. Maunsell Richardson, the Duchess of Newcastle, Elizabeth, Countess of Wilton, and Mr. A. V. Pryor, Colonel Brocklehurst, the Duke of Penaranda, Mr. WV. Baird, Mrs. C. IV. B. Fernie, Colonel the Hon. W. and Mrs. Lawson, Miss Lawson, Mr. Herbert Gosling, Mr. Robert Heathcote, Mary, 
Lady [Gerard, Lord and Lady Castlereagh, Mr. and Mrs. H. C. Bentley, Major and Mrs. R. B. Muir, Mr. Hugh Owen, Mr. and Mrs. W. Harford, Captain and Mrs. Burns Hartopp, Lord and Lady Cowley, Mr. and Mrs. S. N. Bankart, Mr. W. A. Chaplin, Major Bradford Atkinson, Mr. and Mrs. F. H. K. Durlacher, Mr. Frank Chaplin, Mr. Vere Chaplin, Sir Henry Jervoise, Sir Arthur Fludyer, Mr. and Mrs. G. Fenwick, Major Hughes Onslow, Colonel Malcolm Little, the Hon. Lancelot Lowther, the Hon. Charles Fitzwilliam, Mr. A. E. Burnaby, Mr. and Mrs. R. Fenwick, Captain Vickerman, Major J. McKie, Mr. and Mrs. Russel Monro, Miss Tryon, Captain E. C. Clayton, Captain and Mrs. David Beatty, Major Wilfred Ricardo, Mrs. Gough, Miss Pelham, Miss Barclay, Major Andrew Coates, Mr. A. L. Duncan, Miss Duncan, Mr. Alec Duncan, Mr. J. Belville, Mr. Alec Cross, the Hon. W. R. Wyndham, Captain N. Allfrey, Mr. F. Murietta, Mr. Worrall, Mr. G. H. Finch, Mrs. Cooper, Mr. and Mrs. Maxwell Angas, Mr. G. B. Parker, Captain A. Smith, Captain J. Burns, Captain Ewing, Major Heycock, Captain R. A. Markham, Colonel Bouverie, Mr. W. P. Cartmell Hubbesty, Mr. H. Drage, Mr. H. Stokes, Mr. Hames, junior, Dr. Norman and the Rev. R. C. Dashwood.

A more classical setting for so brilliant an assemblage than Ranksborough Gorse it would be impossible to imagine, and Thatcher quickly had hounds out of covert close at the brush of a fox. Leaving the Leesthorpe side he ran by Langham away for Ashwell, and was killed after a brilliant burst. A fresh fox jumping up off a plough field, Thatcher and hounds were quickly on his line, going through Ashwell Spinney away for Whissendine, over the brook to Stapleford domains, with slower 


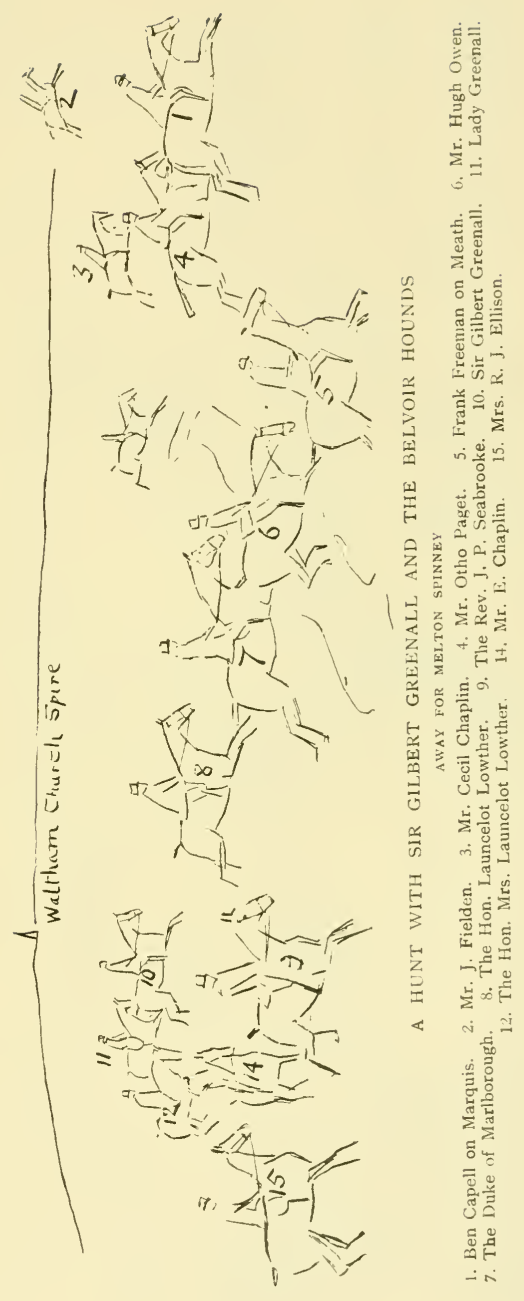





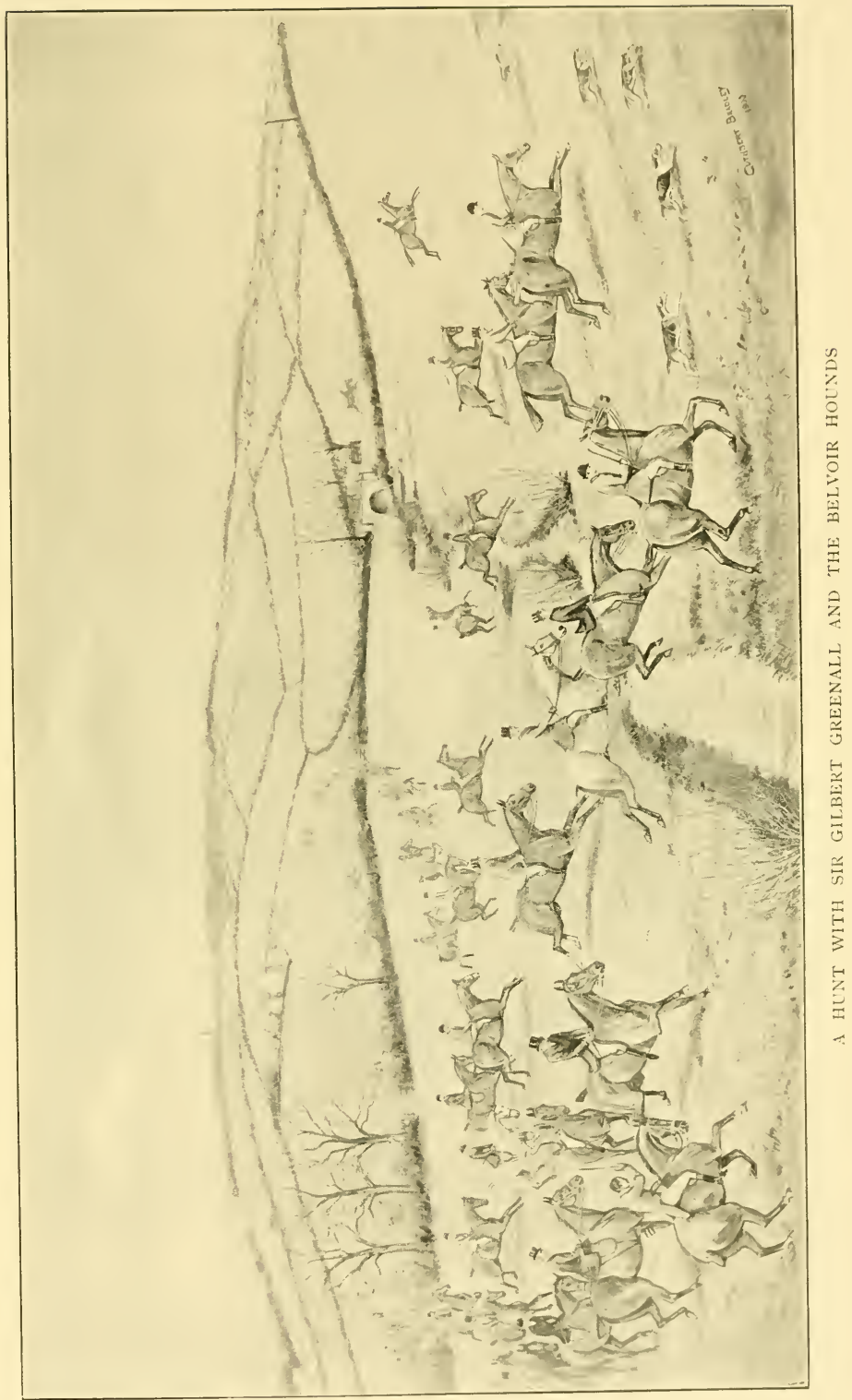



hunting on to Leesthorpe. Many saddles were emptied during the run, including that of Major Muir, one of the best of the top weights, whose horse got impounded in the Whissendine brook through the banks giving way, and was rescued with some difficulty by ropes and a plough team.

At the end of March from the woodlands on the Lincolnshire side by Bourne, one of the best days' sport of the season was seen with straight-running foxes, who piloted the way over some of the best of the Belvoir grass country. Starting from Bourne Wood, hounds drove their fox from the huge coverts in this district, running over a rough bit of plough and grass country to Aslackby, where the brook brought some to grief, and, twisting by Laughton, Thatcher had the satisfaction to handle his fox, after a fine hunting run of ninety minutes. Finding again in Kirkby Wood, another strong fox covert of huge acreage, they had the good luck to run a six-mile point over the grass and the Belvoir steeplechase course below Lenton up to Humby Wood, where scent gave out. The field included the retiring master, Mr. Evan Hanbury, and the master elect, the Earl of Lonsdale.

Tom Firr often took a "huntsman's holiday," having a bye-day with a neighbouring pack, and Arthur Thatcher recalls one of these occasions when he rode with the Cottesmore. "I remember finding a fox at Berry Gorse, and Tom Firr was out, riding one of Mr. Russel Monro's horses. We jumped into the Melton road together; he rode on the right hand, and I was on the left of hounds. Running fast to Cold Overton Wood, I asked him to go on, and he viewed the fox away for me. We finished with a mark to ground in a drain close to Oakham after a very good hunt. I always thought Tom 
Firr the finest huntsman and horseman I ever saw."

Subscriptions for a testimonial to Arthur Thatcher were received at the end of the season by Colonel Brocklehurst and Mr. W. A. Harford, a purse of money being presented to him in recognition of the fine sport he had shown during the seven seasons he carried the horn for the Cottesmore. Returning to the scene of his former triumphs when a whipper-in, Market Harborough was jubilant at his appointment to the post of huntsman to Mr. Fernie's, on the retirement of Charles Isaac. It was said the demand for houses and stabling in the country was unprecedented, a striking testimony to a huntsman's popularity and ability to show sport. 


\section{CHAPTER XV}

THE MARQUIS OF EXETER'S HOUNDS HUNTING THE HARE AND THE FOX

The Marquis of Exeter's Hunt started I $899-$ From hare to fox-The register of kills-Mr. Harry Armour of point-to-point fameThe Hopetoun House harriers-Churlish, a Peterborough champion - Valid, a Peterborough champion-Pocket beagles-Aswarby Park - Whichcotes who were high sheriffs of Lincolnshire--The country described-The kennel huntsman-Two typical hare hunts-A fox day-An early start cub-hunting with the Marquis of Exeter-Another early morning on Cannock Chase with the South Staffordshire-The wild game on Cannock Chase-A good day and a kill in the Fen.

"A diff'rent hound for every diff'rent chase Select with judgment; nor the timorous hare O'ermatched destroy."-SOMERVILLE.

Followers of the Belvoir, Cottesmore, Blankney, and Fitzwilliam's hunts owe the Marquis of Exeter a debt of gratitude for establishing a pack of hounds at Burghley House, by Stamford, which he hunts himself on the border-land districts of these particular countries. There was a time in the life of his lordship's distinguished kinsman, the late Marquis of Salisbury, when a grateful hunting community would have voted solid for the Marquis of Exeter being appointed huntsman to the Royal Buckhounds, a post he could have filled with distinction. But the loss to Lincolnshire and foxhunting would have been a heavy one, for Lord Exeter works hard in the cause of public affairs, and the sport he shows to a scattered community, cheers and invigorates many who required more hunting to keep them in the proper spirit.

For several seasons Lord Exeter hunted the hare, 
and the Burghley House pack were harriers under 20 ins. in height, with a hunting staff clothed in green. In this way they visited various countries by invitation, giving the fox-hunting community many an acceptable bye-day. After a time, when the merry little harriers had learnt all there is to know about the wiles of a hare, they chased and slew a maundering sheep-dog, and then achieved greater things by killing an Aswarby fox after a capital hunt of thirty minutes at a good holding

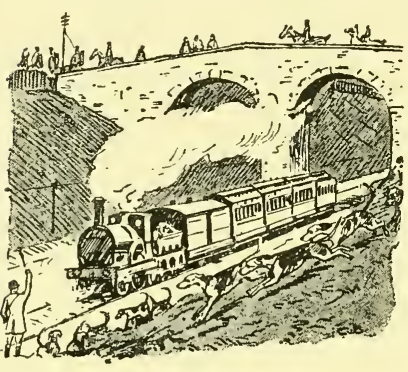

Over the Line. pace. Since then Lord Exeter has abandoned hare hunting, and now pursues the fox two and three days a week during the season. Though a few of the original harriers still remain in the pack, nailers in their work, the standard of height has been increased with foxhound blood, and every year sees an improvement so far as size and pace are concerned.

The original pack was twenty-one couple, ten and a half couple of which were dogs, and a very useful pack of harriers they proved themselves. The hares killed the first season, viz., in I899, were 55 ; in Igoo, 33 ; IgOI, $4 \mathrm{I}$; I9O2, 70 ; I9O3, 34. But much of the country hunted by Lord Exeter was overstocked with hares, which was not good for sport, eventually determining him to turn attention to the fox. Looking through the kennel list there is evidence of the best strains of harrier blood, with representatives by the Boddington Borderer, Mr. V. Pryce's Corsair, Mr. Quare's 
Galloper, Major Robertson Aikman's Prelate, the Fox-Brush Valiant, Vale of Lune Ruffler, Mr. Lloyd Price's Cruiser, the North Bucks Warbler, and then suddenly appears the name of Belvoir Villager, bringing about a new era of sport.

The term harrier is more or less an open one, for foxhound blood nowadays plays a very important part in the formation of a pack. The Hopetoun House harriers, the property of the late Marquis of Linlithgow, swept the board of prizes at Peterborough years ago, and were dwarf foxhounds in type and colouring. A very high standard of excellence was maintained in the Hopetoun kennel, and in January 1903 we saw twenty-seven and a half couple of $2 \mathrm{I}$-inch hounds, paraded on the flags by George Isaac, the kennel huntsman. To paint the portraits of these hounds we stayed with Mr. Harry Armour in Edinburgh, of point-topoint fame in the north, who with his daughters, Miss Nairn and Hazel Armour, see a great deal of hunting with the Linlithgow and Stirlingshire hounds. The following is a characteristic verse written by J. H. R. on an occasion when Mr. Harry Armour rode his horse Hollyhock to victory in the L. and S. hunt heavy-weight race, I905-

"From point to point, from field to field,

The pride of place I ne'er did yield,

As I'm a sinner!

In scarlet coat and whitest stock

I cantered home on Hollyhock,

An easy winner!"

In the Hopetoun House kennel the display of feet, legs, necks, and shoulders was marvellous right through, presenting a Belvoir appearance in miniature. The blood represented Mr. Brookes', Major Wickham's, and Colonel Aikman's hounds, with 
Belvoir, the foundation of all excellence, not very far removed. Those we saw most of when composing a picture group were Churlish, a six-season hunter and Peterborough champion. Her lines were most captivating; a beautiful type in miniature, standing on the best of feet and legs, with neck and shoulders cast in the Belvoir mould. Churlish was by Mr. Brookes' Woodman from Charity. Valid, another Peterborough champion, and three-season hunter, was by Mr. Brookes' Vanguard from Trollop, and she had a more racing appearance. The dog selected to complete the trio was Warlock, by Mr. Brookes' Woodman from Wistful, a beautiful little hound combining substance and quality. On the line of a hare Lord Linlithgow, who was his own huntsman, told us they went like lightning, and it required a stout one to stand up for twenty minutes before the pack. The pocket beagles we saw on this occasion were even more wonderful, fifteen and a half couple of $8 \frac{1}{2}$ and Io-inch miniature foxhounds, who ran a buck rabbit with a cry which would have delighted the pucks and fairies, so suggestive were they of spriteland! The pick of the kennel were Love-knot, Little Un, Weasel, Lucy, Whiting, Tipsy, Trifle, Baby, and Trinket.

Of days' hare-hunting seen with Lord Exeter we have many pleasant memories, especially on occasions when he brought his hunt for a week's visit to Aswarby Park, Lincolnshire, where his cousin, Sir George Whichcote, puts them up. The stately old Lincolnshire mansion has always been a centre for the chase, and Sir Thomas Whichcote, a former squire, the grandfather of the Marquis of Exeter, was one of the finest horsemen who ever rode with the Belvoir. From him Lord Exeter doubtless inherits the love of the chase, together with the 
THE MARQUIS OF EXETER'S HOUNDS 2 I9 present baronet, Sir George Whichcote, both of whom for several seasons owned the great Sir Thomas's hunting saddles, which were valued as priceless. With the hounds kennelled close to the Hall, and the horses stabled all over the village, there was an atmosphere of sport in the air which roused the whole district to activity. That Aswarby

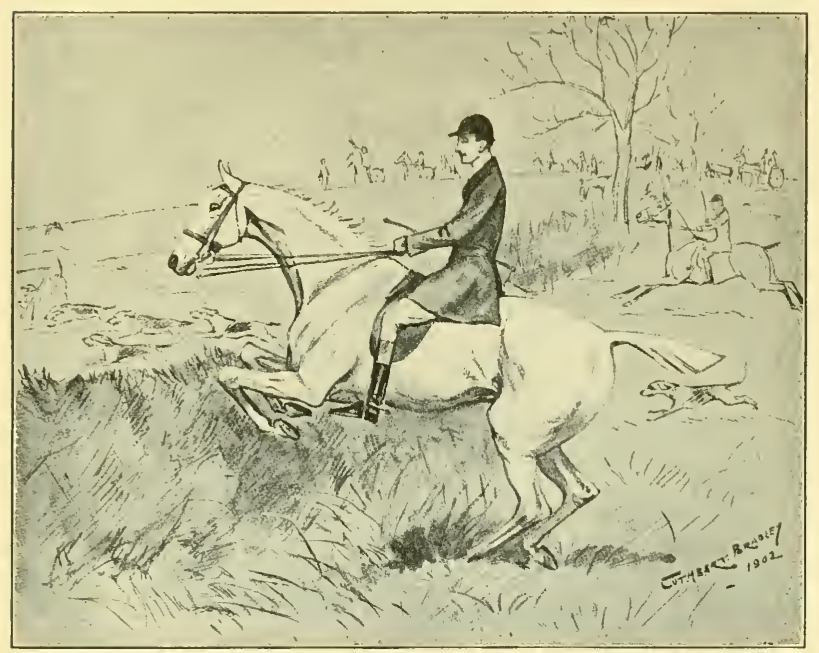

The Marquis of Exeter, M.F.H.

is placed on the extreme eastern borders of the Belvoir hunt, instead of in the centre, is our misfortune, for it is one of the best nurseries for foxes. It is interesting to note that baronets named Whichcote were high sheriffs of Lincolnshire in I466 when Edward IV. was proclaimed King, and in I76o when George III. came to the throne. Again, in I837, the late Sir Thomas Whichcote proclaimed Queen Victoria, and in Igor the present baronet, Sir George, was high sheriff of Lincolnshire. 
Lincolnshire is a great sheep country and therefore not very well adapted for the chase of the hare, when hounds are inclined to hang about longer than wanted in the district. As a school for riding, harriers have proved themselves a capital institution, and amongst Lord Exeter's following, whether riding in Lincolnshire or Northamptonshire, there were always a large contingent of farmers to be seen. The master himself is always to the fore in the full enjoyment of a ride, and amongst his stud of hunters generally has two or three grey horses which carry him well. The kennel huntsman, F. Summers, has been with Lord Exeter all the time, and came from the Bedale, where he was second whipper-in, amongst his stud being a chestnut, and a roan with a Jorrocks-like head and tail. Both horses are everlasting and able to get anywhere. Every sort of country is hunted, beginning with his lordship's own extensive property round Stamford, much of it light, arable land with stone walls and not the best of scenting ground. Practically through the season the pack hunt two days a week by invitation in Mr. George Fitzwilliam's country, much of it deep woodland, and some heavy plough, strongly fenced. Hunting in the Belvoir country between Aswarby and Rauceby, the going varies from strong wet clay to light barley-land-capital hunting ground well foxed.

Amongst typical days' sport was one after meeting at Sapperton, the residence of Mr. and Mrs. Cecil Rudkin, in November I902, Lord Exeter having sharpened up his pack with some purchases of Peterborough winners. Handling them beautifully, they made rings in the Lenton Brook district, rather a formidable obstacle to cross and recross during the progress of the chase. Led by his lord- 
ship, quite a large field included the Marchioness of Exeter, Mrs. H. T. Timson, Mrs. R. J. Ellison, Miss Whichcote, Miss Mutter, and a young lady on a small pony that disappeared several times during the hunt in the deep blind dykes. It was a hunt that put a good many on the ride, and we explored a large area of country between Humby, Lenton, and Keisby.

One of the best days' sport was on the grass round Sempringham, after meeting at Birthorpe, the residence of Mr. and Mrs. John Tomlinson. The fences in this district are quite big enough, but, piloted by the master riding a grey horse, the diminutive pack of fourteen and a half couple described a hunt of forty-five minutes, and killed their hare near Primrose Lane, in sight of Sempringham Abbey and the golf links. A great many people were out on foot to see this hunt, occupying a commanding position on the hill-side, the excuse for a pleasant day in the open spent within hearing of hounds.

Though the last few seasons Lord Exeter pursues the fox, he still wears the green harrier uniform, and his pack is a welcome institution in a country which is limited to two days a week, owing to the distances from kennels. Meeting at Aswarby Park in November I907, the field out included the Marchioness of Exeter, Sir George Whichcote, Mrs. Montague Thorold, Mr. E. W. Griffith, Mr. Lionel Trower, Mr. P. C. de Paravicini, Captain White, Mr. E. Royds, Mr. G. H. Mutter, the Hon. W. R. IVyndham, Miss Laura Willson, Miss Amcotts, Mr. W. H. Wilkinson, Mr. B. Casswell, Mr. Sharpe, Miss Earl, Mr. Smith, Mr. Tinsley, Mr. Dickens, Miss M. Dickens, Mr. H. Clarke, the Rev. E. L. Treffry, the Rev. F. M. P. Sheriffe. Aswarby Thorns sup- 
plied the needful, and a rousing good gallop resulted over a country that rode very deep but carried a scent to Silk Willoughby, where with slower hunting they reached Rauceby and killed.

Four o'clock in the morning for the month of August is an hour considered necessary to catch the early morning dew and a scent. The Marquis of Exeter was one of those who started season I908-9 as usual on grouse-shooting day, reaching covert in the dark, having to wait twenty minutes for the first streak of dawn before throwing hounds in. The select field to meet him, included one of the number driving a gig, who arrived a good first with his lamps lit! Scent served, and before a return was made to kennels at eight o'clock, when the sun was blazing hot, a brace of masks adorned the whipper-in's saddle.

These early mornings' hunting in August have a charm all their own, and we have memories of a hunt with the South Staffordshire presenting a scene of diversified loveliness. Staying over-night with Mr. F. Villiers Forster, the master, at Longdon Grange near Rugely, we were aroused next morning before four o'clock to start the cub-hunting campaign on the last day of August. Variety of scenery and conditions of hunting are offered by the wild, hilly tract of moorland, known as Cannock Chase, some forty thousand acres of heather and bracken. Undoubtedly in early times an oak forest of great extent existed here, and there is a tradition that a squirrel could spring from tree to tree, some twelve miles, from Hammerwich as far as Buxton. Solitary oak-trees still exist on the Chase, with belts of firs and spruce to break the masses of purple heather and golden bracken. This wild spot of delightful 
scenery is the haunt of all kinds of game, and we saw, in our ride on the moor, grouse on the wing, partridges, black-cock, besides fallow-deer. As the pack streamed away on the line of a fox up the distant hill-side, throwing their tongue in joyful chorus-for heather carries a tremendous scent when wet-we experienced the ecstasies of a wild chase far away from the signs of human habitation. A reliable pilot and experienced mount are necessary to cross this moorland in safety, for the tracks are hard to find and there are bogs and grips to entrap

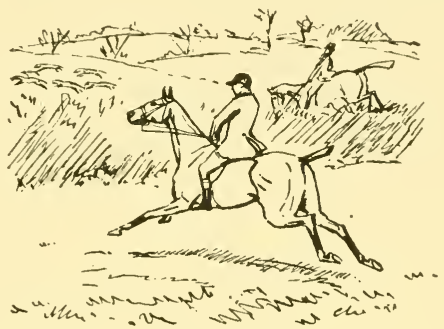

A Quick Hunt.

the unwary. Hounds, as a rule, can beat horses in this district, and the resourcefulness of a pack to hunt for themselves may be seen under the most picturesque circumstances. A fox running in heather is an extremely difficult object for the unpractised eye to view in the distance, so closely does his colour harmonise with the surroundings. The South Staffordshire kennel is coming to the front at Peterborough, where already they have figured in the prize-list.

In spite of the vagaries of weather and the very hard going which characterised season I9o8--9, the Marquis of Exeter's hounds did well. One of the best days of the season was after meeting at Aswarby 
in January, when they roused an outlying fox on the borders of the fens round Burton, and after an eventful hunt across an unexplored country, where hounds had not been seen for twenty years, they killed him in an outhouse at the edge of the Blankney country. 


\section{CHAPTER XVI}

\section{IVITH THE BELVOIR FROM COSTON COVERT \\ TO WOODIVELL HEAD}

Buckminster Park-The Belvoir hounds viewed at covert-side-Ben Capell-Jack Hewitt-H. Norman-A Belvoir field, 1908-9-A preliminary Leicestershire frolic on the heath country-A view of Coston covert- "Notice to quit" on the horn-Pace the elixir of the chase-Runs from Coston covert in the Sixties-The record time of a Coston covert to Woodwell Head run--Speed tests and measurements-Those there February $188 \mathrm{I}-\mathrm{A}$ good riding field, January I 883-A very fast gallop, February i 892, and those thereTwo red-letter days from Coston covert in $1895-96$ and the leading division-A Coston covert fox-brush for the Hon. Mrs. Lancelot Lowther-A Coston covert fox-mask for the Hon. Francis Lambton - The find-A typical Leicestershire burst-The kill below Woodwell Head.

"But little need was there to-day By Coston Thorns awhile to stay, For scarce the eastern side we gain, Scarce tighten girth and bridle-rein, Ere Cooper's halloa sounds away!

A gallant fox brooks no delay."

- Coston Run Song of January 1 7, 1863.

THE lawn meet at Buckminster Park, the Leicestershire seat of the Earl of Dysart, is always an attractive fixture, drawing a distinguished Wednesday following of the Belvoir from the Leicestershire and Lincolnshire sides of the country. The fine mansion, built in the Grecian style at the end of the eighteenth century, makes an ideal setting for a meet of hounds, with extensive drive and lawn allowing a full view of the assembled crowd. Standing on the high ground overlooking a vale of grass and home plantations, with a fine hunting country stretching 
away to the south and the west, there is always the prospect of a good day's sport.

On a certain Wednesday we rode to Buckminster Park, to which point every road with its contingent of second horsemen and motor-cars appeared to lead. From the earliest days in the history of the Belvoir this classic pack has scored some of the fastest gallops on the quick-scenting grass country in the surrounding district. While the gay throng taste the stirrup-cup provided by Lord Dysart's hospitality, hounds swarm round the huntsman's horse, the privileged group to set foot on the trim lawn, looking "the handsomest pack in England at covert-side." Many judges of the past regarded the Duke of Rutland's hunt as the very embodiment and type of the best side of our national sport, and we realise to-day that this high position is maintained in an age too when so many other establishments may be counted as excellent. Sir Gilbert Greenall's appointment of the hunt is in keeping with the high standard shown by the pack, for the hunt horses are quite as level in appearanceblood-like hunters, on short legs, with the best of backs and shoulders, all being docked and trimmed like fighting-cocks. Ben Capell, who began life under Tom Firr, is a Leicestershire huntsman bred and born, his methods of conducting a hunt being in keeping with modern ideas. The chances are he is riding one or other of his Wednesday mounts, Zephyr or Black Cap, both bay browns that match so well that it is difficult to distinguish one from the other, for he sits with that unconscious ease which gives the appearance of a centaur-like form. A hunter under sixteen hands, a narrow horse, quick as lightning, would appear to suit Capell best, but he seldom rides the same for more than three 
seasons; the constant change on to new mounts in the full vigour of life has probably reduced the average of falls taken by the Belvoir hunt staff to a minimum. The first whipper-in, Jack Hewitt, is a short man and an extraordinarily good hunt servant, always there to put hounds to his chief with the least fuss and bother; Jack or Desborough may be his mount, and he has that happy knack of being in the right place to view a fox or give a lead. Cast in the mould of a horseman, long and light, Herbert Norman, the second whipper-in, has the gift of hands and seat to please the most critical eye. We may talk of pipe-clay and button-drill for exactness, but the way the whole of the Belvoir hunt-staff wear their uniform, even to the blackheaded tie-pin, is a reveletion of workmanlike smartness,

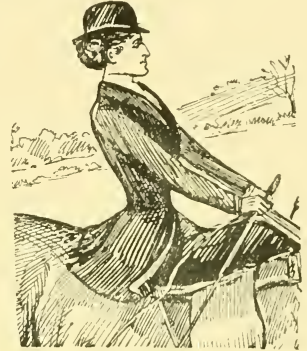

Mrs. Asquith. the effect of completeness leaving nothing to be desired.

Amongst the large crowd assembling are Sir Gilbert and Lady Greenall and their two smart boys on ponies; whilst from Belvoir Castle are three of the Duke of Rutland's daughters, Ladies Marjorie, Violet, and Diana Manners, amongst the keenest when hounds run, with Lord Robert Manners their uncle; Mr. Edward Griffith, riding a long-tailed grey horse that looks like sixteen stone on the grass, is there to undertake the arduous duties of fieldmaster, with Mrs. Griffith on a chestnut, the Duchess of Newcastle, the Countess of Wilton, and Mr. A. V. Pryor, Captain Burns-Hartopp, ex-master of the Quorn, and Mrs. Burns-Hartopp, Miss Mary Hartopp, 
Colonel the Hon. W. A. and Mrs. Lawson, Mr. and Mrs. R. B. Sheriffe, Victoria, Countess of Yarborough, and Mr. J. Maunsell Richardson, Captain and Mrs. R. J. Ellison, Mr. and Mrs. C. J. Phillips, Colonel and Lady Julia Follett, Mr. and Mrs. R. Clayton Swan, Lady Angela Forbes, Mr. H. de Paravicini, Mr. and Mrs. Chandos de Paravicini, Mr. Ernest Chaplin, Captain Holloway Steeds, Mrr. Vincent Hemery, Mr. Charles Newton, Captain and Mrs. Pritchard, Mr. and Mrs. F. H. Schwind, Captain and Mrs. J. F. Laycock, Mr. Tom Hare, Mr. G. Drummond, Captain G. Paynter, Miss Paynter, Major G. Powell, Captain and Mrs. Mann Thomson, Major and Mrs. R. B. Muir, Miss Muir, the Hon. W. R. Wyndham, the Hon. E. and Mrs. Wyndham, Mr. H. T. Barclay, Colonel Theobald, Mr. James Hutchinson, Sir Keith Fraser, Captain and Mrs. A. J. Palmer, Mr. and Mrs. R. L. Fenwick, Mr. and Mrs. G. Fenwick, Colonel Smith, Mr. A. Hutchinson, the Hon. H. R. Scott, Colonel Brocklehurst, Mr. Vere Chaplin, Major R. A. Markham, Captain and Mrs. Archibald Smith, Major Rennie, Mr. and Mrs. R. E. Strawbridge and Master Strawbridge, Mr. and Mrs. H. M. Escritt, Mr. Chesterman, Mrs. Jefferson, Mr. A. Turner, Miss Turner, Sir Charles and Miss Welby, Mr. L. Duncan, Miss Duncan, Mr. R. Millington Knowles, Mrs. le Marchant, Mr. and Mrs. Max Angas, Mr. J. F. Cartmell, Sir Robert Filmer, Colonel and Mrs. E. H. Baldock, Sir John and Lady Milbanke, the Marquis of Cholmondeley, Lord George Cholmondeley, Mary, Lady Gerard, Lord and Lady Gerard, Major J. B. Atkinson, Mrs. H. G. Pease, Baron de Forest, Mr. IV. H. Mildmay, Miss Moore, Miss M. Sedgwick, Mrr. and Mrs. M. Stocks, Captain Thatchell, Mrr. O. F. Mosley, Mr. A. Wheeler, Major E. J. R. Peel, 
Mr. and Mrs. I.indsey Smith, Colonel Eiric Smith, Lady Evelyn Cobbold, the Hon. Ivor Ciuest, Captain the Hon. G. H. D. P'ennant, Mr. J. P. Crenfell, Mr. F. B. Mildmay, Captain H. Ashton, Mr. Niven, Major and Mrs. W. Ricardo, Mr. W. P. CantrellHubbersty, Mr. McKeane, Mr. C. Tompkinson, Major A. Coats, Major Ewing, Mr. J. and the Hron. Mrs.

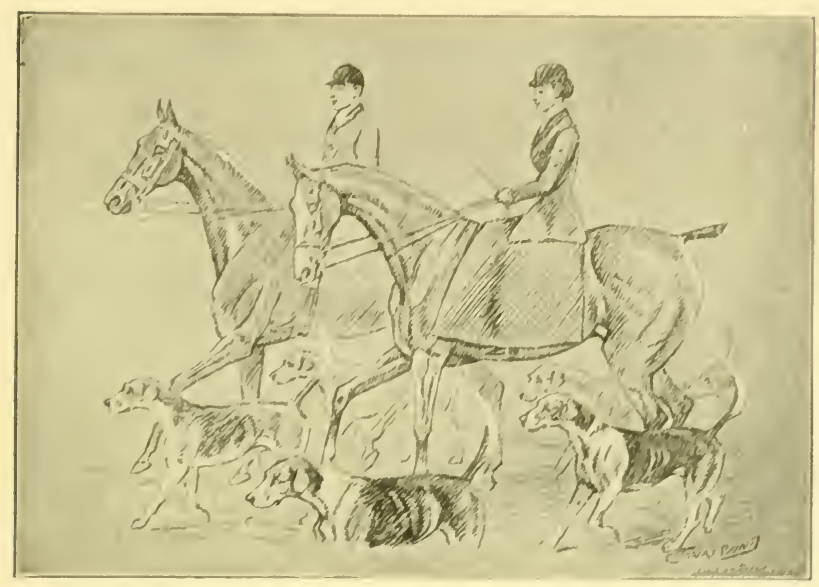

Sir Gilbert and Iady rreenall.

Gretton, Mr. A. E. Purnaby, Mr. H. R. Langrishe, Mr. Bernard Wilson, Lady Catherine Hill, Captain Vickerman, Mr. and Mrs. S. Whitburn, Mr. and Mrs. C. Hay, Captain J. W. Burns, Captain W. R. Rorlen, Mr. and Mrs. F. H. K. Durlacher, Mr. and Mrs. E. Peacock, Mr. J. O. Paget, Mr. W. Wilkinson, father and son, Mr. and Mrs. C. Craddrock, Mr. IV. Gale; Mr. J. H. Bellamy, Mr. G. Pellamy, Mr. J. Sellamy, Mr. R. C. Cooper, the Rev. J. Gorst, the Rev. J. P. Seabrooke, the Rev. F. II. P. Sheriffe. Every side; of social life and activity is represented, a striking 
testimony to the extent to which hunting has become part of the interests of all classes.

The day was gleamy with sunshine and passing cloud, a slight north-westerly breeze stirring the

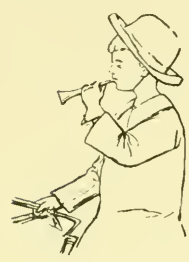
bare branches of the plantations which back the Hall, and with good going all the conditions combined to make it an ideal hunting morning. It generally happens that the first order is to go down into the grassy vale to the plantations below the park, which may mean an excursion on to the heath, and the opportunity to let off that superfluous energy, after which horses and riders sober down to take on the serious business of a day's hunting. The sight of such a display of hunters, the pick of the stables of Leicestershire, is alone worth going many miles to see, for, spread out on the undulating galloping ground of the park, it is possible for the eye to take in the magnificent pageant at a glance. As hounds chase a fox from one or other of the home plantations and get him into the open heath country, the hunt goes riding along in battalions, jumping the inviting heath fences twenty abreast, an enjoyable preliminary Leicestershire frolic, quite devoid of fierce competition.

About midday the scene is changed, the hunt turning for the high country to try fresh ground lying south of Buckminster village; then, when it is realised that Coston covert is the order, the top division from Melton and Grantham are all on the qui vive for an impending struggle, which may mean the best item of a season's sport. The sight of Jack, the first whipper-in, cantering on leaves no doubt that the historical covert is our destination, 
a precaution that is necessary, for the sound of the trotting cavalcade might move a fox and rob a hunt of its brilliancy. Riding across the two undulating grass fields gives the first view of Coston covert, a line of stunted thorns on the hill-top in cold shade when seen on the north side. Not until it is approached by the narrow ride gate at the north-east corner does its charm of surroundings

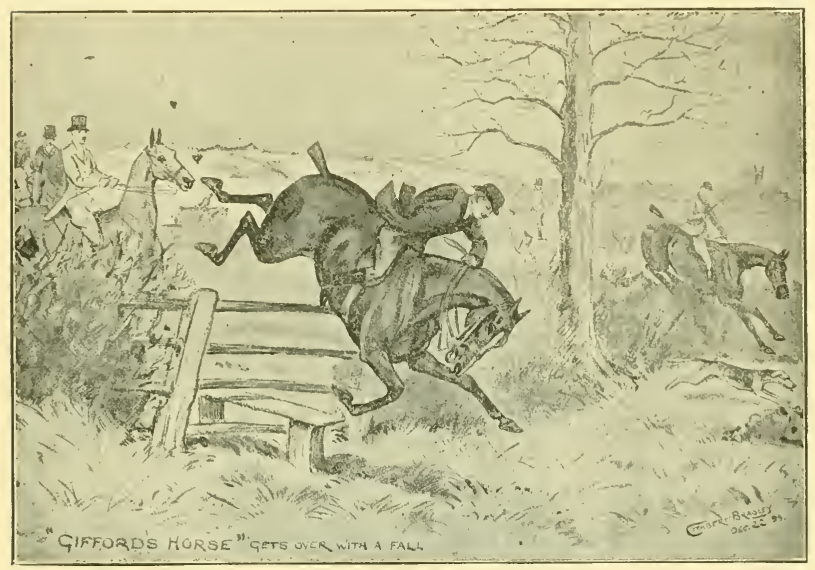

The Hon. Maurice Gifford.

appeal to the eye. Gently sloping to the south there is the witchery of colouring on tree and thick undergrowth lit up by the soft winter sunshine. A typical Leicestershire fox covert of about ten acres, it is an ideal spot, from which hounds get away with a flying start, to launch out across a perfect panorama of undulating grass country, stretching away as far as the eye can reach. The sky-line melts into blue distance, and, if the light is good, it is possible to distinguish the bold outline of Woodwell Head by Market Overton, some four miles 
away on Cottesmore territory. Trees are few and far between, just sufficient to break up the hedgerow lines which make a network tracery over the sea of grass. You may search the landscape for signs of human habitation, only to find one or two solitary farmsteads miles apart, presenting an ideal sporting paradise. Blow from which point the wind may, there is no smoke from town factory, or taint from high farming, to rob the grass land of a scent left by a fox going straight for his life to the covert, nearly four miles away.

As Capell approaches Coston covert with hounds he follows precedent by sounding the preliminary "notice to quit" on the horn, which echoes back, the silence being broken by the harsh notes of a magpie as he saucily flicks out of the thicket. Let us hope our luck is right, bird of doubtful omen! for though more thrilling gallops can be recorded from this covert than any other in Leicestershire, there are seasons and occasions when it has failed. Sir Gilbert and Lady Greenall pull up by the narrow ride-gate, and the rest of us possess our souls in patience, waiting for the master to touch his horn, the signal for a flying start, and the rush of pent-up energy led by the best riding talent of the day.

An up-to-date pursuer of the fox, when asked to give a definition of a perfect day's sport, is reported to have said, "Twice round the Aylesbury steeplechase course, and home to lunch." A dart from Coston covert to Woodwell Head with a racing scent would pretty well meet this ideal summary of a perfect hunt, for the Belvoir have covered the distance, which measures just under four miles as the crow flies, in twelve minutes. Since the early days of hunting the line has always been considered a trial of speed for horses and hounds, who 
on many occasions have done the distance without the semblance of a check. The horse, however, that can catch the Belvoir on a quick-scenting day in this country has yet to be foaled, though up-todate hunters are bred on racing lines. This is only one more instance of the marvellous construction of the foxhound, possessing the speed and the

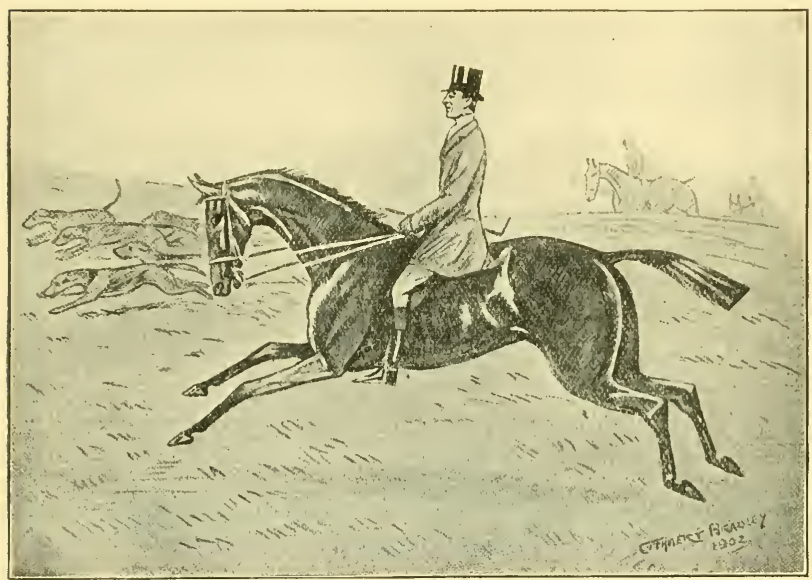

Mr. R. Clayton Swan, Ex-M.F.H.

endurance to tire three horses, the one measuring 24 inches at the shoulder, the other 64 inches.

Looking back to the annals of the Belvoir as recorded by the late Rev. John Welby, one of the finest horsemen of his day in the Sixties and Seventies, who left a volume of memoirs, dedicated to the sixth Duke of Rutland, we find some interesting Coston covert records. In I863 when Frank Gillard, the subsequently famous huntsman, was riding second whipper-in to James Cooper, the covert for a season was in disgrace owing to 
hounds having picked up poison, and it is recorded that on February I7th it was drawn by boys, the hounds being kept outside. They drove a fox out, the hounds were laid on, running by Edmondthorpe, up to Woodwell Head, on by Barrow, to ground in Cottager's Gorse-time, forty minutes.

Again on December I4, I864, when Gillard had been promoted to first whipper-in, hounds drew Coston covert for the first time after the poisoning, and a fox broke directly, but with only eight and a half couple of hounds. These got away close at him and raced down to Garthorpe; rising the hill to Saxby Spinney, they skirted Stapleford Park and ran over the fine country by Teigh to the Green Lane from Ashwell to Langham, where Cooper's horse fell dead under him, Mr. G. Drummond lending him his. The fox lay down in a hedgerow and hounds ran over him, but being brought back they killed. It was a splendid fifty minutes, and there were many falls. Numerous other good days are recorded much farther back at the very commencement of hunting history, the covert having always been favoured fox-ground.

The pages of Frank Gillard's "Reminiscences," published in I898, give many interesting accounts of Coston covert days. Referring to the events of November I4, I877, Gillard says, "From Coston covert hounds raced with a breast-high scent to Woodwell Head, accomplishing the distance in twelve minutes. Gillard took the time, so did the Rev. J. Mirehouse, of Colsterworth, who was always 'a good clocker.' The Duke of Rutland was very pleased when he heard of this brilliant burst, and remarked that it proved the Belvoir hounds were faster than in Goosey's time."

Any argument of speed entering into the story 
of a hunt cannot be taken as conclusive testimony, and we are reminded in a letter from Captain S. King, who hunted many years from Melton, that "A generation before the days of Squire Osbaldeston - viz., about I766 - Blue Cap and Wanton ran clean away from a field, mostly riding thoroughbreds, on Newmarket Heath; so hounds

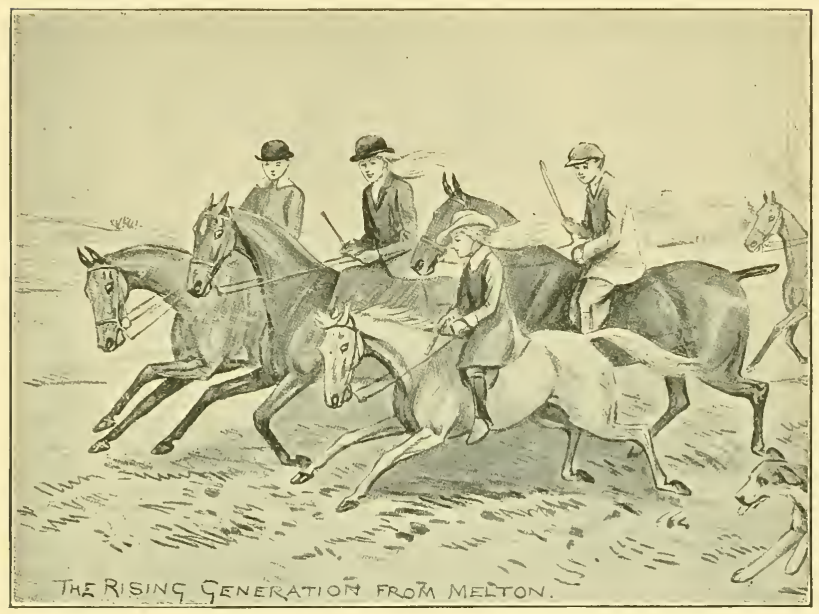

From Melton.

could travel in those remote days!" Then as to a certain distance of country being jumped in a specified time, the Grand National course, which measures 4 miles 856 yards, was covered on a memorable occasion, March 26, I909, in 9 mins. $53 \frac{4}{5}$ secs. Yet anybody may ride a Grand National horse hunting, and some do so-with permission from the master to catch hounds on a quick-scenting day, if they can! The story of the run in a grass country on a quick-scenting day is generally about the same: "There was no one within half a field of the 
pack." Measurements also of jumps taken out hunting seldom convey much, and the best of them may be beaten in a circus ring by so many feet or inches. Yet every one who goes hunting knows, that a quick thing to hounds in a strongly-fenced country is the finest test of the sterling worth of horse or rider.

"The fastest gallop of the season happened on February I6, I88I, from Coston covert, hounds racing like wild-fire towards Wymondham in the direction of Woodwell Head, and back again to the starting-point, squandering a large field of over three hundred followers. Those nearest to them were Captain 'Doggy' Smith, Mr. John Welby, and Will Wells," so Frank Gillard tells us.

On January 24, I883, a long and fast gallop was seen from Coston covert to Woodwell Head, away for Freeby, ending with a kill near Stonesby-time, two hours and twenty minutes. Amongst those who rode this run were Lord and Lady Grey de Wilton, the Hon. H. H. and Mrs. Molyneux, Major the Hon. and Mrs. Stirling, Colonel the Hon. H. H. Forester, Mrs. Sloane Stanley, Miss Turner, Sir Hugh Cholmeley, Captains Tennant, Penell Elmhirst, Tom Boyce, Messrs. A. V. Pryor, Burdett-Coutts, Henry Chaplin, H. T. Barclay, A. Brocklehurst, J. Hutchinson, Westley Richards, George Drummond, F. Roy, Coutourie, the Rev. J. Mirehouse, and Rev. J. P. Seabrooke.

A day full of riding experiences comes under the heading of February Io, I892. Gillard remarks that it was the best day of the season, hounds getting away from the south-east corner of Coston covert close at their fox, and, never leaving his brush, ran by Woodwell Head and Crown Point, which was reached in twelve minutes, ending with 
a mark to ground in Gunby Warren after slower hunting, the full time being twenty-five minutes. Amongst those who had the best of it were Lord Lonsdale, Lord Drumlanrig, the veteran Colonel the Hon. H. H. Forester, who will always be remembered as "The Lad," Captain Blair, Captain Lee Barber, and the Rev. J. P. Seabrooke. Gillard remarks, "I never saw so many dirty coats from falls at the finish, my own included."

Warburton might have written his verse for the occasion-

"If my life were at stake on the wager,

I know not which brother I'd back;

The parson, the squire, or the major,

The purple, the pink, or the black."

In Gillard's last season, I895-96, two red-letter days resulted after visits to Coston covert, the first being on December I8, when hounds fairly flew from Buckminster Park through Coston covert by Wymondham, checking on nearing Woodwell Head, with slower hunting past Teigh to Edmondthorpe. The time from Buckminster Park to Woodwell Head was twenty-three minutes, with another seventeen to the check at Edmondthorpe. Nearest to hounds, though never within half a field of them, was Lord Charles Bentinck, Mr. de Winton, Mr. Edgar Lubbock, Mr. V. Hemery, Mr. H. T. Barclay, the Rev. J. P. Seabrooke, Mr. Will Gale, Gillard, Harry Maiden, and Sam Gillson. On this occasion Gillard was well carried by a bay horse named The Miner, a bold, big jumper, and at the end of the season, when the hunt horses were sold at the Leicester Repository, he went for twelve guineas.

A repetition of the gallop came off on January I, Igo6, and once again the chosen few sat down to ride as though the winning-post was in view; those 
nearest to hounds were Lord Edward Manners, Mr. and Miss Musters, Mrs. Cecil Chaplin, Mr. C. R. and Miss K. Hodgson, Mr. F. Worsley, Captain J. Rennie, Mons. Roy, Mr. James Hutchinson, Mr. Heldmann, the Rev. J. P. Seabrooke, and Mr. W. Gale.

With Ben Capell's advent on the scene as Gillard's successor in 1896 , the sequence of stirring events from Coston covert continued, though for the last few seasons no run of note has taken place. The first was in February I897, when hounds travelled very fast on the line of a fox, and the little brook on the left of Wymondham emptied several saddles, five getting in all together. Heading straight through Woodwell Head, Capell lifted hounds forward, killing his fox handsomely in the vale by Ashwell. The brush on this occasion was presented to the Hon. Mrs. Lancelot Lowther.

It is always the unexpected that happens, and the best gallop of the season was scored at the end of February I907, when the wind was blowing a perfect hurricane and all the elements were at war. The morning hunt, with Sir Gilbert Greenall in command, was from Goadby Gorse, past Waltham Thorns, to Coston covert, where the bitches killed their fox. Perhaps the second hunt was even more brilliant, and only a half-dozen with Ben Capell were with hounds as they flew on the line of a fresh fox from Coston covert to Woodwell Head, the distance being covered in twenty minutes. Avoiding the covert, they ran on to Cottesmore Gorse, and killed their fox, stiff as a stake, by Teigh village. It was the best forty-five minutes of the season, run in a gale of wind and hail, the bitches being so savage at the finish that only the mask was secured by Ben Capell, who presented it 
to the Hon. Francis Lambton. Amongst those who were nearest to hounds in this fast hunt were Lord Cholmondeley, the newly-elected Cheshire fieldmaster, the Hon. Francis Lambton, Captain and Mrs. R. B. Sheriffe, Mr. W. Harford, Mr. Frank Schwind, Mr. W. Wilkinson, and Mr. W. Gale.

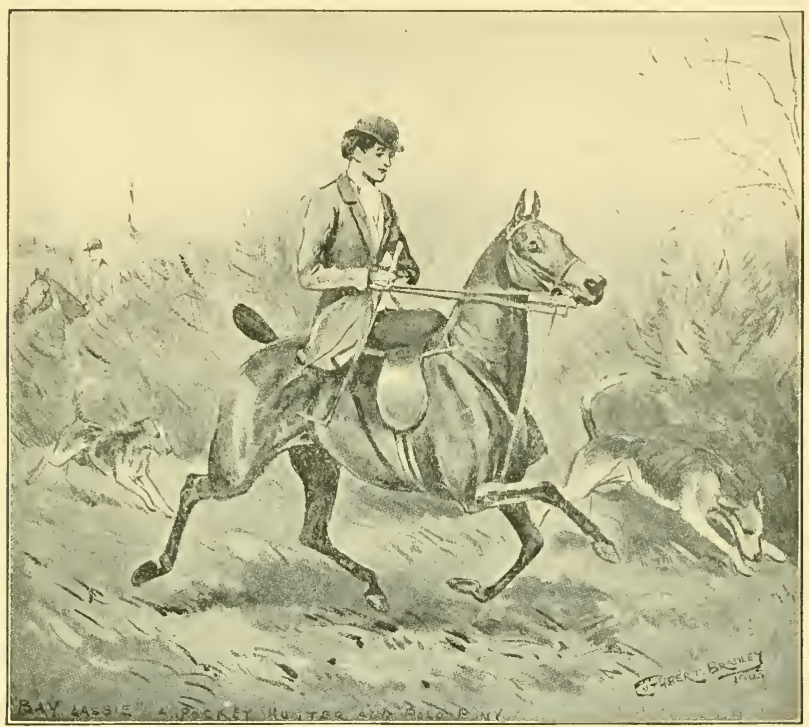

A Miniature Hunter.

Every one is full of hope and expectation when a hound speaks in Coston covert, and the crowd packed by the narrow gateway have something to do "when the flag falls" to disentangle and jump off with that start which means being with hounds, or carrying on a hopeless chase in the rear. Ben Capell, moving up the covert, cheers the opening note with a "Huic, huic!" the chorus swelling, for a fox is on his legs, though loth to leave the 
comfortable quarters. A turn in covert results in a few minutes of uncertainty, for if he should break back for the neighbouring Buckminster Plantations little in the way of sensational sport will result. Horrible thought! he may try ringing tactics once too often, and with sixteen and a half couple close at him in the undergrowth he must get chopped. The pack come to the north corner, and two couple flash out on the grass, then all goes quiet, and some opinion they have killed him. It must have been a near thing, but he is on his own ground clever enough to slip back, and, finding covert too hot to hold him, a ringing view halloa from the northeast corner proclaims him away! Instantly every horse seems to be electrified; there is a whirlpool of ardent spirits striving to get a start, but held up by the master's voice of authority, "Hold hard! pray, h-o-1-d h-a-r-d ! don't go on !" Capell's horn rings out, and to it fly the eager pack, streaming away with a rippling, chiming cry that tells of a scent. It is on these occasions that the top men of the hunt suddenly appear on the scene in their accustomed place with hounds, as though they had dropped from the clouds!

For the rest of us, filtering through the gateway or thrusting through the gap in the tall fence on the left, it is a tortuous proceeding, attended with considerable danger, for they say that the worst that could happen in a battle charge was to be rubbed off your horse by companions in arms. Quickness and decision are the salient points of a successful Leicestershire leader, whom we know so well in the distance "cantering alongside the leading dog," whilst our division is " riding hell for leather," galloping a great deal faster and losing ground all the way. In the first few fields of rough 
grass land away from covert, there are grips and ant-heaps, which account for one or two empty saddles quite early. Then the brook which winds its way up the valley wants knowing, for to turn right-handed to the bridge and the road means losing one's place and probably the hunt for the rest of the day. In the undulating grass country it is possible to see a mile or more ahead, the fields being large and the fences swishy black-thorns

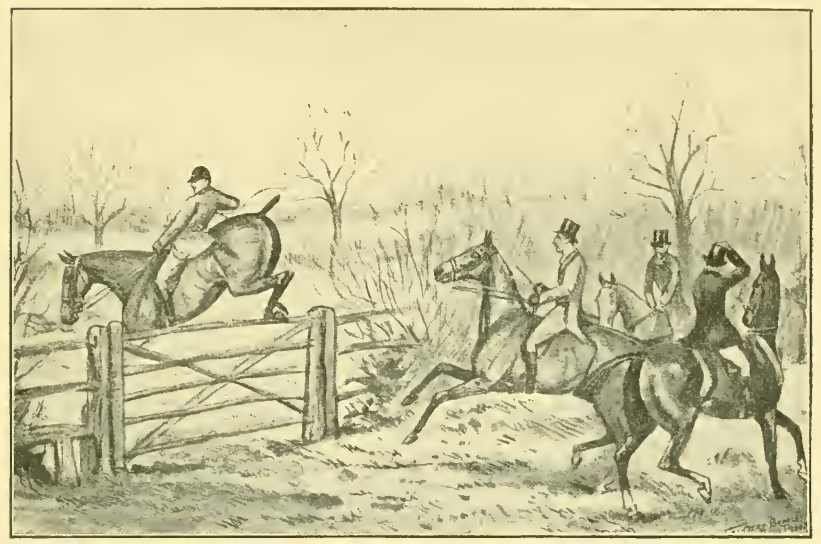

Capell leads the way.

well within the compass of a hunter's stride. It is the pace which spreads out the following like a fan in the track of the vanishing pack! Starting in high hope with a good view of hounds leads one to believe that we are fairly in it, but it generally ends with galloping in the lanes, track hunting, riding with a wet sail to reach the covert on our right hand, where we hope a check will put us on terms again. The high country near to Woodwell Head, after passing under the iron stone railway, is rather more enclosed with tall, untrimmed fences, making 
it a matter of difficulty to see very far ahead, and this fact tends to urge on our wild career to get in touch again. Drawing rein by the strong covert with its stake-and-hound fence, we listen to catch a sound, but, like phantoms of the night, our leaders have vanished, leaving no evidence but feet markings and a few established gaps. Pressing forward, the heart as well as the steam rather out of us, we ride the grass fields at a sobered pace, looking down into the glorious vale stretching away below Market Overton up the valley towards Ashwell and Oakham. Our horse gets a view a shade quicker than we do; the hunt-like specks in the distance are down below, the select band of happy, hot riders having pulled up. There is a momentary hover of the pack, and then we see the hunt staff swing from their saddles. It is an inspiriting picture and instils new life, for with rousing energy the straggling army press on down the hillside in time to catch Ben Capell's triumphant Who-whoop! and the savage chorus of the pack. Another Coston and Woodwell Head gallop has been put on record, by no means the least interesting of many good hunts, for, after all, there is no time so happy as the present. Well carried by Lord Roberts, a I6-stone dark brown horse with a white face, the occasion is one to be remembered for many a day to come, though we were not always in the same parish with hounds. 


\section{CHAPTER XVII}

\section{NOTES FROM THE BELVOIR KENNEL}

The history of the Belvoir in a nut-shell-Expert opinion on the influence of the kennel on foxhound breeding-The late Queen Victoria's opinion of Belvoir Castle-The picturesque position of the kennelsThe sixth Duke of Rutland-The seventh Duke of Rutland-A Duke of Rutland's luck in kennel matters-Sir Gilbert GreenallBrocklesby Rallywood ('50) - Belvoir Weathergauge ('76)-The history of Belvoir Weathergauge ('76)-Belvoir Fallible ('74)-Belvoir Gambler ('84) - Belvoir Pirate ('86) - The strength of the kennel when Frank Gillard left it-Belvoir Dexter's ('95) full pedigreeBelvoir Dexter ('95) - The Rev. Cecil Legard and Mr. Austin Mackenzie on the flags at Belvoir-Dexter captivates all the critics -Ben Capell's management of Dexter-Sir Gilbert Greenall as a hound-breeder - The great entry of I 899-The Belvoir sires Vagabond Stormer and Handel ('99) - Success of Belvoir sires at Peterborough, I899-Mr. James Hoyes' cup--Belvoir Dasher (I900)Dasher's pedigree-Radical top of the Conservative pack, and subsequent chaff-Duke John's story of old Goosey told at the Puppy Show luncheon-Presentation to SirGilbert Greenall on his marriage, 1900-Tom Firr's last public appearance and speech-Captain Pennell Elmhirst's opinion on the kennel, 1905-Day-Star and Helper ('o5) - The great entry of I9o6-Ragman, Rufus Weaver-Weaver ('o6) described-Warlock and Whitaker ('o6) - A note about the late Lord Willoughby de Broke-The eighth Duke of Rutland-The meet at Belvoir Castle, I909-IVeaver kills the last fox of the season I908-9--The brush and mask go to two young sportsmen-The entries of 1908 and 1909--The key to the Belvoir kennel.

"Let us stroll to the kennels that lie in the grounds

Of good old Belvoir,

To talk with the huntsman and look at the hounds-

The good old Belvoir.

How deep is each chest, how strong is each thigh, How broad is each muzzle, how gentle each eye;

But see them from Sherbrooke's across the vale fly,Good old Belvoir!"

\section{Referring to "Cecil," the Belvoir Hunt-which dates back to 1750 -became a foxhound pack in I 762 ; and with the exception of the period I830-57,}


during which Lord Forester officiated, the mastership has always been held by a reigning Duke of Rutland until the appointment of Sir Gilbert Greenall in I896.

The word "classic" describes the Belvoir kennel and its surroundings better than any other, for it is the Mecca to which every houndsman turns, as Captain Pennell Elmhirst exactly expresses it, " to refresh the memory, attune the eye, and renew one's notion of the ideal." Expert opinion has pronounced the Duke of Rutland's pack at Belvoir a national institution, the recognised source of the

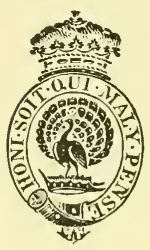
purest foxhound blood in the kingdom for those seeking improvement for any other kennel. The privilege extended by successive Dukes of Rutland has had the effect of raising the standard of foxhound-breeding all over England, many beautiful packs being built up by the Belvoir blood. As Mr. Nevill Fitt, in "CovertSide Sketches," says, "Where is the man possessing a pack of foxhounds who does not try for a bit of Belvoir? In fact, it is as hard to get away from in foxhounds as that of Waxy amongst race-horses; and there are few who will not admit that a dip into it has been of great service to them!" The Belvoir kennel is the home of the thoroughbred foxhound, a very high standard of excellence having been maintained by a succession of huntsmen, the best of their day, who held long periods of office, and followed the same system of breeding.

Belvoir and fox-hunting are interchangeable terms, for no history of the one can possibly be complete without frequent mention of the other. From the topmost turrets of the castle a huge panorama of Leicestershire hunting country may be 


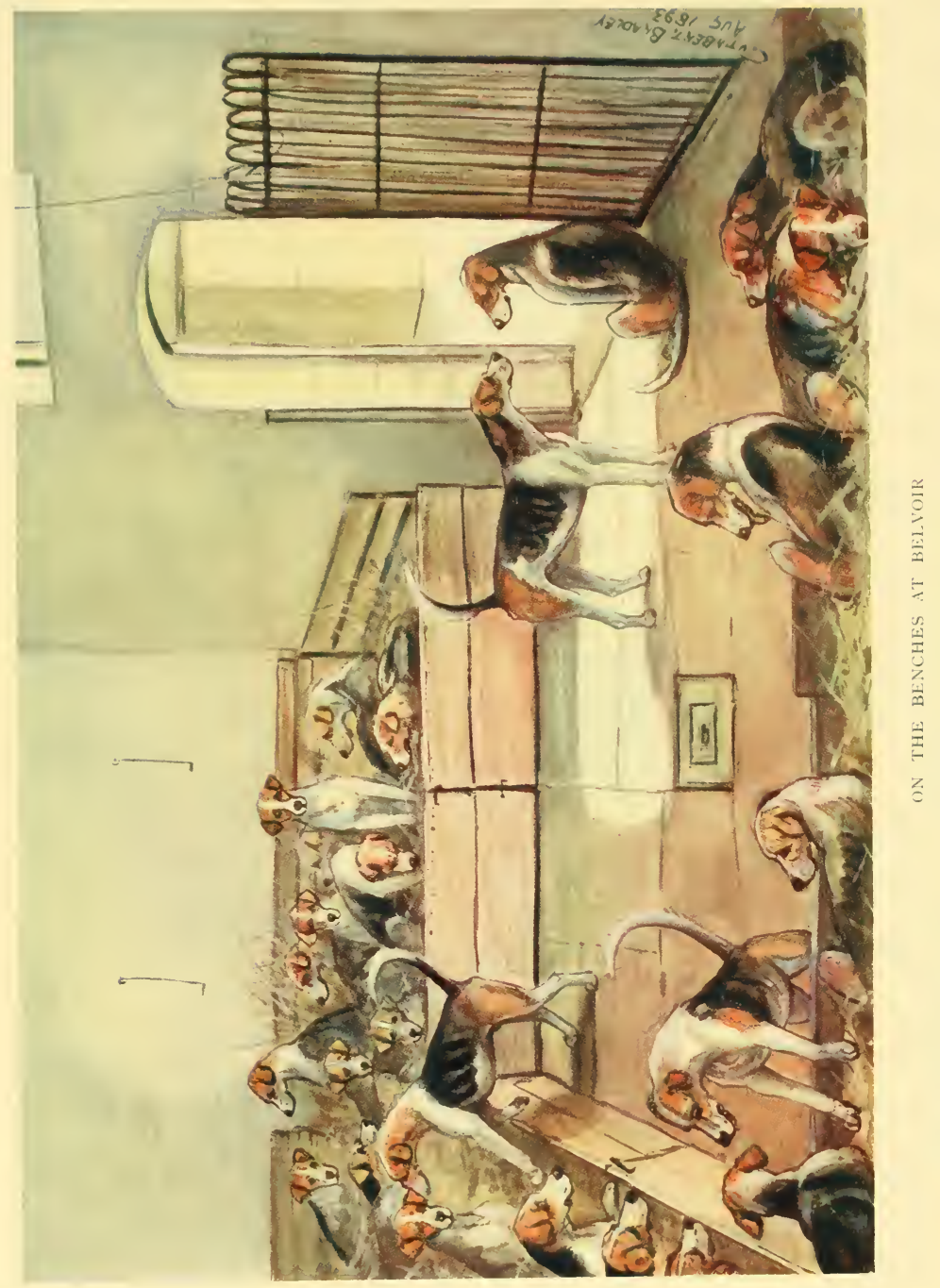



NOTES FROM THE BELVOIR KENNEL 245 obtained, classic ground on which the mightiest Nimrods of all ages have delighted to disport themselves. Absolutely unrivalled in position, the castle-crowned heights of Belvoir are impressively grand, whether wearing the garb of spring or autumn. It is recorded that the late Queen Victoria with the Prince Consort, when on a visit to the sixth Duke of Rutland in I843, greatly admired

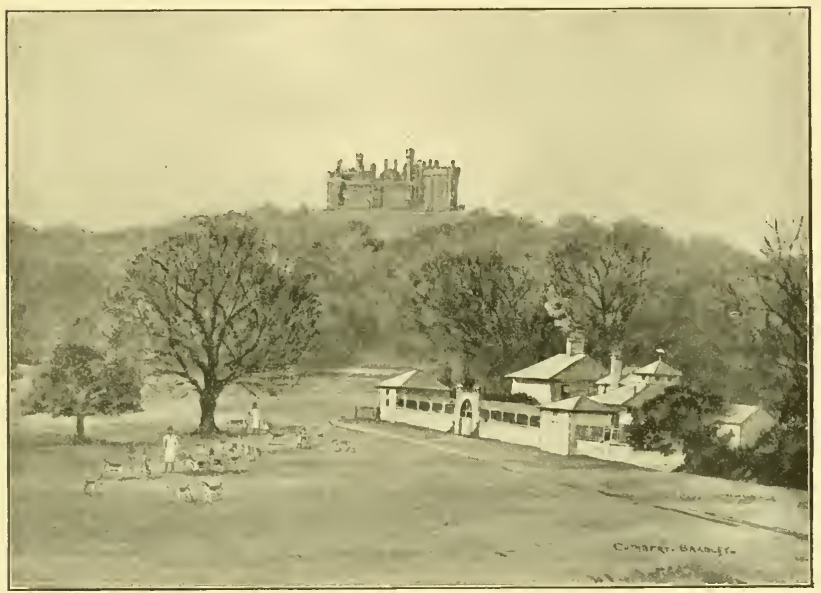

Belvoir Castle and Kennels.

Belvoir Castle and its surroundings, comparing the Leicestershire seat of the house of Manners to royal Windsor, which it in some way resembles, but is better in grouping and stands on higher ground.

Through the park below the castle runs the river Devon, and by the side of the lake are the present kennels, built in I809, the hounds before that time being kept at Croxton Park and Ropsley. There are few more picturesque spots to be found in England, and the kennels seen against the rich foliage of the Belvoir Woods impress the eye with 
their grandeur and completeness, suggesting a perfect paradise of fox-hunting, shadowed by the splendidly massive towers of the castle.

Personal experiences come under the mastership of two Dukes of Rutland and Sir Gilbert Greenall, with two huntsmen, Frank Gillard and, since I896, Ben Capell. In eight seasons' sport

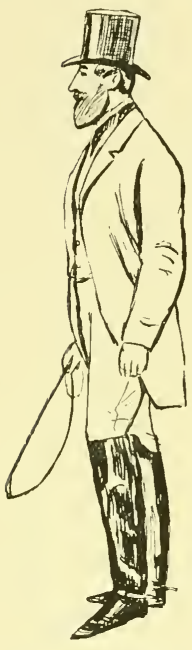

Lord Charles Manners, 6th Duke of Rutland. under the sixth and seventh Dukes of Rutland, it was the rarest occasion that we ever saw the noble master out hunting. Though a very resolute rider in his day, Lord Charles Manners, sixth Duke of Rutland, was unknown to the present generation, incapacitated by age and infirmity from following the sport he loved so well long before his death, which occurred in I888. Succeeded by his brother, Lord John Manners, seventh Duke of Rutland, and eminent statesman, with Frank Gillard as huntsman, sport pursued the even tenor of its way, until master and huntsman retired from the cares of office in 1896 , to the great regret of the whole fox-hunting world. That so distinguished a personality as the seventh Duke of Rutland was interested in sport is a very strong argument in its favour, for the social side of hunting appealed to the late Duke, giving him the greatest satisfaction to know that his hounds were a source of pleasure to all the country-side.

The Dukes of Rutland have always been most successful in choosing the right men to rule over the destinies of the family kennel, evidently possessing a keen, discriminating power to judge character. This is clearly proved by the succession of hunts- 
men chosen during the past hundred and twenty years, dating from the time of Thomas Goosey, Will Goodall, James Cooper, and Frank Gillard, who all served long tenures of office, maintained the same traditions in the kennel, and, building on the foundation laid by predecessors, were able to leave the hounds better than they found them. No wonder that the eyes of the whole hunting world were centred on Belvoir, when Lord John Manners, seventh Duke of Rutland, decided to relinquish the mastership, retaining possession of the hounds and kennels, which he magnanimously lent to the country and his successor. An embarras des richesses of substantial offers to hunt the country were, of course, forthcoming, and the Duke finally invited Sir Gilbert Greenall to accept the mastership, the son of an old Parliamentary colleague, owning a large property in Cheshire. The sub-

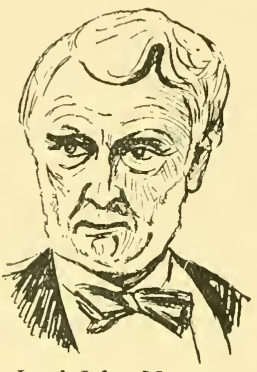

Lord John Manners, 7 th Duke of Rutland.

sequent events during the past thirteen seasons have proved the wisdom and soundness of the Duke's choice, for even in a time when all hounds have improved very rapidly and are considered to have made more progress than any other animal, the Belvoir are still standing quite alone in appearance, and doing every. kennel good that goes to them.

A hound that did an immense amount of good, establishing the type of the Belvoir, was Brocklesby Rallywood, bought in I85o by Will Goodall from the Earl of Yarborough's kennel. His blood to-day is diffused through every fashionable kennel in England, the Belvoir inheriting many sterling good qualities 
from his son Rallywood. Will Goodall described the Brocklesby dog as a 23-inch hound, on short legs, exceedingly light of bone, but with beautiful legs and feet. In Rallywood's first season at Belvoir, fifty-three couple of his puppies were sent out to walk, and the Druid relates that " when he died in I853, twelve years old, he was buried in the centre of a flower-bed in Will Goodall's garden, and a red-currant tree now blooms over his remains." A picture of Rallywood, painted by John Fernley, hangs in Belvoir Castle, and he is one of the very few purchased hounds that have found their way into the kennel.

Good hounds are to be found in plenty, but great hounds appear on the scene about once in ten years. The first we saw on the flags at Belvoir, who has gone down to posterity as a great hound, was old Weathergauge (' 76 ) in his last season. We can just remember his wise grey face, as Frank Gillard put him forward, the veteran of the pack, in his eleventh season. Weathergauge ('76) was by Warrior ('70), who was the son of Wonder ('64), the son of Chanticleer, the son of Chaser, the son of Brocklesby Rallywood, brought to Belvoir in I 850 . Wonder gave the pack tongue, and his dam, Willing, was a noted bitch by Rallywood, son of Brocklesby Rallywood. Warrior's pedigree has two hits to Mr. Drake's Duster, two to Rallywood, and two to Senator. Senator ('62), the great hound of his day, bred by James Cooper, was by Singer out of Destitute. Singer was by Comus, out of Syren by Mr. Drake's Duster ('44), out of Sprightly by Grove Singer. Destitute was by Sir Richard Sutton's Dryden, out of Tuneful by Trouncer, out of Skilful by Grove Stormer. All the Senators could drive and use their noses. 
In Gillard's opinion Weathergauge was the best hound he ever saw in every part of a run, possessing nose, tongue, drive, constitution, and devilry when breaking up a fox, qualities which he transmitted to his stock, who always have plenty to say about it, no matter how hard they are running. In appearance Weathergauge was a disappointing hound, being flat-sided and short in the neck, but he never sired anything so mean-looking as himself, and Gillard kept very close to him when breeding. His voice was true; he had only to speak and all the pack would fly to him; carrying a line down a road he was unsurpassed, and absolutely reliable when making a cast. To-day the weight of opinion is all in favour of the Weathergauge strain for good looks and good work, no matter what the nature of the country to be hunted may be-grass, plough, stony wastes, or deep woodland. When discussing Belvoir pedigrees, houndsmen seldom go farther back than to Weathergauge, for in him the pack culminated, as it were. Chance may be said to have played an important part in the career of Weathergauge, for, being a plain hound, he was included in the draft, and offered for $f_{\text {Io }}$ to $\mathrm{Mr}$. Albert Brassey, who would not have him. A parallel case was that of Furrier. Drafted from the Duke of Rutland's kennel because he was not straight, and purchased by Squire Osbaldeston, he eventually blossomed into one of the most-sought-after sires ever recorded in hunting history, though old Thomas Goosey would not use him for the Belvoir-not even after he had established his fame!

Another great hound bred by Frank Gillard was Fallible ('74), the result of an out-cross with the Fitzwilliam, for he was by Milton Furrier, from Prophetess. He showed true foxhound style in every 
line, possessing clean shoulders, deep, full chest and ribs, intelligent, shapely head, and supple, muscular limbs. Fallible was pronounced by the late Lord Willoughby de Broke to be the best hound of his day, the Duke of Grafton also offering a large sum of money for his purchase. A great hound in his work, Gillard used him extensively, and we get his blood through Dexter ('95) in the fifth generation.

Weathergauge's most illustrious son was undoubtedly Gambler ('84), from Gratitude ('80), the top bitch of the kennel by Gallant from Snowdrop, straining back to Senator. A hound of immense substance and beautiful quality, Gambler, as a type of strength and symmetry, was the ideal for sculptor, poet, and painter. Standing 23 inches at the shoulder, he showed great muscular development, with bone right down to his toes. Rich in colouring, his head had that brainy appearance suggestive of the highest intelligence. In the field he was perfect and everlasting, running with the pack up to his eleventh season, when he was drafted for deafness, allowed to roam at large in the woods around the kennels, an honoured pensioner. Gambler's services were in great demand as a sire, and he comes into pedigrees wherever there are hounds of any note, his stock being remarkable for their durability and stoutness.

Pirate ('86), by Procter ('8I) from Night-watch, combining the blood of Struggler and Founder, was another celebrity bred by Frank Gillard, considered by some the best stallion hound of his day. $\mathrm{He}$ was a red-tan dog, a good-bodied hound, deep in the rib and wide in the loin, standing on capital feet and legs. Pirate had but one fault-he never wanted to leave off hunting.

When Frank Gillard retired in I896 from the 
position of huntsman to the ducal pack, after carrying the horn for twenty-six seasons, he left a superb kennel full of hounds. Some packs in England may show six stallion hounds worthy of the title, but Belvoir puts forward twenty or more, the wherewithal to strengthen a pack, to maintain its bone, to improve the type of its brood bitches. The Belvoir is one family bred out into branches that are by no means remote from the parent tree, and when Gillard left the kennel the three great clans were the Gambler's, Pirate's, and Shamrock's. Amongst the stallion hounds was Watchman ('92), the son of Nominal ('88), the son of Gambler ('84), beautifully bred, combining the blood of Weathergauge and Milton Solomon. All the Gambler sort are rather a long hound, low, and level, with immense muscular development and bone, brainy heads, and throw strong family likeness into their "get." Apart from the well-known colouring of recognised " Belvoir tan," the richest blue-black and purest white, these hounds show remarkable substance, power, and weight in proportion to height, and their ribs have a tendency to be deep rather than round.

Frank Gillard's last entry at Belvoir contained the peerless Dexter ('95), who, under the mastership of Sir Gilbert Greenall with Ben Capell huntsman, became the most fashionable sire of the last quarter of a century. All the critics pronounced him the handsomest hound ever seen on the flags, and in his work he was a good, honest foxhound. Dexter's pedigree is a triumph of breeding, combining all the best-working strains in the kennel, nicking on both sides to Weathergauge descended from Brocklesby Rallywood. As a beautiful type of the modern thoroughbred foxhound, Dexter captivated the eve at once, showing the characteristics of gay colouring, 
PEDIGREE OF BELVOIR DEXTER, 1895

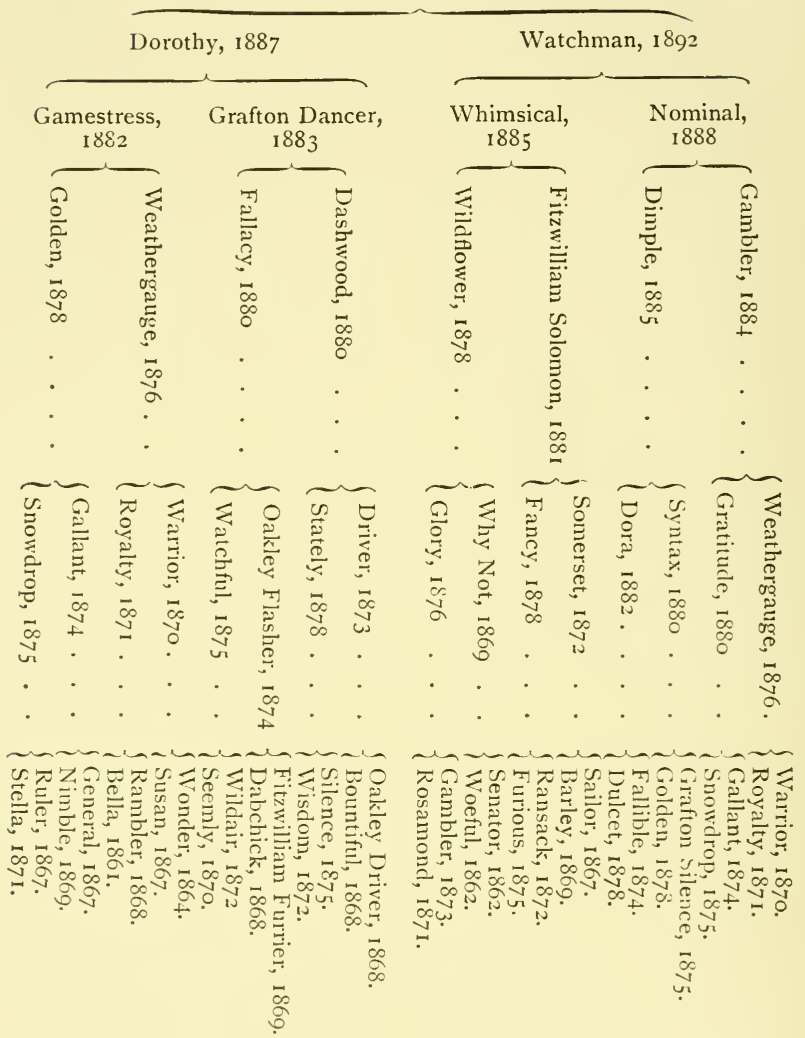

Wonder ('64) was by Chanticleer, the son of Chaser, the son of Brocklesby Rallywood. IVonder gave the Belvoir tongue, and his dam, Willing, was a noted bitch by Rallywood, son of Brocklesby Rallywood. Senator ('62), the greatest hound of his day; was by Singer, by Comus, from Syren, who was a daughter of Mr. Drake's Duster. 
symmetry, strength, and quality, which distinguish the Belvoir blood. His countenance was expressive of a generous, good-natured disposition, but, like all the Weathergauge family, he was a resolute hound when roused or in chase. Measuring just under 24 inches at the shoulder, he was a longwaisted hound of great elegance, beautiful quality, and great power, though less massive in build than his great-grandsire Gambler. A wonderful hound to show himself, he was active as a kitten, skimming over the flags like a swallow on the wing. To-day, no matter what kennel we set foot in, a Dexter countenance is there to greet us-a beautiful, intelligent, tan face with a brainy head, which he transmitted to all his stock. For ten seasons Dexter was on the active list, a corner-stone in kennel history, eighteen and a half couple of his sons and daughters being in the pack at Belvoir when he left it, with twice as many grandchildren-the greatest appreciation that could possibly be shown to a sire who won lasting fame. A grateful huntsman put old Dexter to rest under an apple-tree in his garden, near to the grave of his famous ancestor Brocklesby Rallywood.

No better orator than the Rev. Cecil Legard could be found to pay a tribute to great Dexter's memory, and this he did in a characteristic speech on the occasion of the Puppy Show luncheon at Belvoir in July 1905. Recalling his first sight of Dexter in the spring of 1895 , it was easy to imagine the sensation made by this glorious young hound, even on one whose experience enabled him to gauge his merits by generations of past celebrities. The Rev. Cecil Legard since the year I869 has paid an annual pilgrimage to the classic kennel, one of the first to enjoy the sight of each successive entry on 
the flags, whose breeding is of the greatest interest to those versed in the science of pedigrees. With his reverence, whom we have mentioned before as the founder of the Foxhound Stud Book, was Mr. Austin Mackenzie, whose fame as a hound-breeder was established when master of the Woodland Pytchley from I885 to I899, in which comparatively short time he bred a beautiful pack, skilfully blending Lord Henry Bentinck's old blood with that of Belvoir. In the year I899 Mr. Austin Mackenzie sold his pack for 5000 guineas, the Duke of Beaufort purchasing the dog-hounds for 3000 guineas, and Mr. W. M. Wroughton the bitches for 2000 guineas.

Frank Gillard had shown the reverend gentleman and his colleague the triumphs of the kennel, the Donovans, the Watchmans, Pirates, and Gamblers, a bewildering display of feet, legs, necks, shoulders, and gay Belvoir colouring. The two critics closed their note-books with a sigh of satisfaction, for three hours spent on the flags with Frank Gillard used to fairly gallop. Harry Maiden, the first whipper-in, in attendance on the huntsman, turned to him and said: "I think, sir, you have forgotten to show the gentlemen the young Watchman dog!" "Quite right to remind me, Harry!" replied Gillard, with a suspiciously merry twinkle in his eye. "Put Dexter on ; he was very nearly left out!" Then in bounced the hound of a lifetime, displaying the symmetry of a Greek god, the grace of a fawn, and the gay colouring of a butterfly. The Rev. Cecil Legard and Mr. Austin Mackenzie stood amazed, unable to find words of admiration, captivated by what they saw before them. "What does this mean, Gillard ?" at last said his reverence; "Dexter beats all records; the handsomest hound ever seen on the flags at Belvoir." "Ah!" said Frank 
Gillard, the smile dying out of his face, " I thought you would say so. Would that it had been my luck to see such a prize through his career; but there, I've had a great innings and must not murmur!" The little group stood silent, wrapped in thought, a chain of past memories being awakened by the young hound whose future promised so well. Surely life is made up of sunshine and shadow, but the memory of our sport can kindle a flame to warm the heart long after we cease to be actively engaged in pursuit.

The reverie was broken by the arrival of a telegram announcing the death of young Will Goodall, huntsman to the Pytchley, and son of the famous Belvoir huntsman, in which kennel he gained his first tuition as whipper-in under Frank Gillard, for Belvoir has always stood high as a school for huntsmen.

It was Ben Capell's proud boast that Dexter never felt the whip-cord, except on one occasion when an inexperienced whipper-in hit him by mistake. He hunted with the pack into his eleventh season, and then was allowed to roam at large in the park around the kennels, a pensioner, as his illustrious ancestors Weathergauge and Gambler had been before him. Like the celebrated horse St. Simon, Dexter was the sire of many sons famous as himself, who carried on the reputation of the kennel and won champion honours for other packs.

In the kennel Sir Gilbert Greenall, ably seconded by his huntsman Ben Capell, has proved a strong master and a great hound-breeder. A past experience in the science of breeding pedigree stock of all descriptions was of great assistance to the young master, who went to the root of the matter, having the extended pedigree of every entered hound 
worked out to the eighth generation. Following the same lines as his predecessors, he has maintained the high traditions and characteristics of the pack, and the kennel stands alone in having depended entirely on its own breeding for sixty years, no hounds having been purchased in that time, the rule to breed only from the best workers being strictly observed. The strength of the kennel to hunt four days a week is the same as before, sixty-

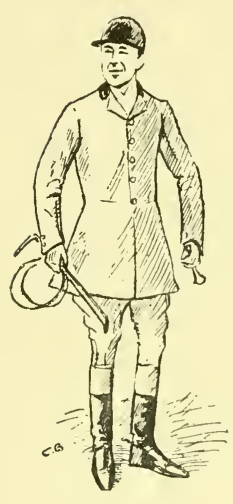

Ben Capell. five and a half couple, numbering about twelve couple of stud hounds, whose services are sought by more than sixty other kennels. Sir Gilbert Greenall further ensured his chance of success as a hound-breeder by instituting an annual show and luncheon for the Belvoir puppy-walkers. These gatherings arouse the greatest enthusiasm and the keenest competition amongst those who walk the young hounds. The result is that stronger and larger entries are forthcoming, and the kennel, full of young blood, is in the zenith of vigour.

The Belvoir in I899 had a great entry; in fact, Brooksby said of it in a preliminary article to the Field before the judging, "The young entry is almost a pack of itself, so full is it of likely brood bitches and probable stallion hounds. Breeders will like to know from what special sources these results have been obtained, and will in many cases obtain the strains that are as liberally open to them as ever. Ben Capell, Sir Gilbert Greenall's huntsman, would seem to be working on much the same lines as have been heretofore so successful, viz., to go as little as possible outside the proven Belvoir 
sources, and to hold legs and feet as almost the next essentials after hunting qualities. The bulk of the present success is due to Dexter, perhaps the most beautiful hound that Gillard ever bred, and with which he delighted the public only the year before his retirement. Thus, with Dexter triumphant at the stud, Gillard can boast of having bred three out of four of the greatest foxhound sires of our time, his other two being Gambler and Fallible; the fourth to which I refer, their equal in symmetry and power, being Quorn Alfred."

The entry, which was judged by the Rev. Cecil Legard and Mr. J. S. H. Fullerton, master of the Badsworth, was headed by Hemlock, one of a wonderful litter by Dexter from Hopeful, a beautiful bitch by Donovan, who was by Rufford Dancer. Handel, of the same litter, was destined to become a great sire, and Heartless, of this litter, topped the bitches. A very valuable stud hound and a great fox-catcher was Vagabond, placed second in this entry. By Vanquisher, who was by Hermit from Grove Hark away, the dam of Vagabond was Ringdove, by Watchman from Rarely, and subsequently the Dexters and Vagabonds became two great clans which nicked well, doing great service for their kennel. Another dog of this entry that made a name as a sire and a "workman" was Stormer, by Dexter from Steadfast, who was by Hermit, a son of Grove Hark-away. In his colouring Stormer showed the characteristic deep black and ticking, so typical of the Grove. To-day Vagabond, Handel, and Stormer are remembered as great sires whose progeny won champion honours at Peterborough for many kennels.

In a speech at the luncheon Sir Gilbert Greenall reminded his guests that " every single hound that 
won a prize at the Peterborough show that summer, with one exception, was by a Belvoir dog." The Rev. Cecil Legard endorsed this statement by adding that "the success of the Belvoir sires showed the absolute importance of maintaining the highest state of excellence. The judges had a difficult task placing the entry, but when opinion is divided it is the best compliment paid to the merits of a pack." The cup this year, won by Hemlock, went to a very staunch fox-hunter, Mr. James Hoyes, of Hanby, who had walked a puppy for the Duke of Rutland more than twenty-five years, quite content if his protégé was considered good enough to gain an entry. The handsome silver cup which Sir Gilbert Greenall presented to him was prized above rubies, but, as he quaintly expressed himself, "It was no end of a nuisance, for he had to carry it up to bed every night." He did not intend any one should have the chance to lift that cup!

The entry of Igoo gave us the first great hound of Sir Gilbert Greenall's breeding, for Dasher, the son of Dexter, was pronounced at once to be even above Belvoir level. An impressively beautiful dog, he looked the model of form and pattern of strength, with the most striking carriage, so much so that many who saw him placed Dasher first as their ideal foxhound for strength and symmetry. The two judges were the Rev. Cecil Legard and the late Tom Firr, and when the entry was paraded on the flags the first thing they did was to turn Dasher out of the ring and judge the rest of them. For the moment this came as a shock to every one present who had picked the winner, and Capell kept up the deception by looking as much as to say, "There, you thought you knew all about it!" Of course, the young dog won by a distance, much to 
the delight of his walker, Mr. J. Jackson, of Harby, expert opinion pronouncing Dasher to be just the sort of sire the Belvoir wanted, long and low, with plenty of stuff. Well ribbed up and the right length in his couplings, with bone well carried down, he stood perfectly on the soundest of feet. There was some weight about Dasher, and a strong-coated dog, he had a wear-and-tear appearance which did not belie his performances in after life; for he was a great hound in chase, easy to note in a run, having a white near-side quarter which caught the eye.

Looking at Dasher's pedigree it is easy to see how valuable his blood was to his own kennel, for on Dexter's side he had Watchman, Nominal, Grafton Dancer, Gambler, Milton Solomon, and two nicks to Weathergauge. The dam of Dasher was Verdant ('95), by Lord Yarborough's Acrobat ('90), who strained back to Belvoir Grappler, Fencer, Brusher, and Fallible, a good pedigree for work. Brocklesby Auditor, by Acrobat, was sold by Lord Yarborough to the Wheatland kennel for 829 guineas. The dam of Verdant was Vengeance ('9o), litter sister to Valiant, and they were by Game-boy ('84), litter brother to Gambler, sons of Weathergauge. The dam of Valiant and Vengeance was Vanity, by Blankney Villager, one of Lord Lonsdale's best sires when Ben Capell was his huntsman at Blankney. Valiant and Vengeance were top of their entry at Belvoir ('90), and the bitch had size enough to run with the dog pack, but all the quality of a 2 I-inch hound. Her neck and shoulders were beautiful, turn of loin and quarters with length of haunch all in harmony, and she stood perfectly on the best of feet and legs.

It was a great loss to the Belvoir when Dasher was killed out hunting during his third season, but 
fortunately he left many beautiful sons and daughters to carry on the line.

In I90I, an occasion when Tom Firr was assisting the Rev. Cecil Legard in judging, the entry of eight and a half couple dog-hounds was topped by Radical, a son of Dexter ('95), Rachael ('99), by Vanquisher ('94)-Ringlet. In appearance he was a judge's hound, showing size and substance rather at the expense of good looks. A story is told about this dog which brings in the name of the late Mr. James Hoyes, of Hanby, to whom this puppy was taken to walk. A promising-looking whelp, he appeared to have found a very desirable home with so good a sportsman, until Mr. Hoyes happened to ask his name. "I won't have him here. I won't harbour no Radicals on my place, not if I know it!" he exclaimed resolutely, and so the puppy, and later on the silver cup, went to a neighbour.

Of course, there was no end of chaff at the luncheon that the best hound in so conservative a pack was Radical, and Sir Charles Welby, who made a speech proposing the health of the judges, rounded the matter off very neatly. "I have always noticed," he said, "that when Radical is first, Havoc is invariably second." This sally called forth a spontaneous cheer, for the judges had awarded the second prize to Havoc, by Rustic ('95) from Heroine ('97). However, it worked out all right, for Radical's name is not to be found in Belvoir pedigrees!

For several years the puppy show luncheons were honoured by the presence of the seventh Duke of Rutland, who came to make a speech, and took the keenest interest in Sir Gilbert Greenall's mastership. "Talking of the excellence of the hounds reminded him of a pretty but pathetic story," said the venerable Duke, "told to him when a boy. 
One of the famous huntsmen, Thomas Goosey, when he retired from active life, spent the rest of his days in a cottage at Woolsthorpe. There was a garden at the back, looking towards the green hill which sloped up from the village of Woolsthorpe to Belvoir. In the early summer mornings his not less famous successor, Will Goodall, used to bring the hounds for exercise, by the garden gate. The old gentleman, seated in his chair, took his hat off, and remained uncovered until they had passed out of sight. That, he thought, was a pretty story, and he was not altogether indisposed to think that perhaps there might be some enthusiastic sportsman in that company, and some admirable, perhaps even critical, judges of hounds who when they met that pack might feel inclined to take their hats off, believing that when they saw them, they represented about as good a type of that noble animal the English foxhound as they were likely to see in the course of their natural lives."

In Igoo the Belvoir Hunt presented Sir Gilbert Greenall with two massive silver cups on the occasion of his marriage with Miss Frances Griffith, daughter of Captain Wynne Griffith, of Tarporley, Cheshire. Lady Greenall at once proved herself to be an ideal wife for the master of the premier packa very finished rider, like her father, able to take her position at the head of a Leicestershire field, and assume command in her husband's absence. A further prize was added by Lady Greenall to the substantial list presented by the master each year, going to the walker of the puppy sent into kennel in the best condition.

Tom Firr's last public appearance in Leicestershire was judging the young entry at Belvoir, August I902. In a characteristic speech at the 
luncheon, he said: "The entry we have been looking at to-day seems to be keeping up the good name of the Belvoir pack. As regards their necks, shoulders, legs, and feet, they are perfection, and this fact reflects much credit upon the gentlemen who have walked the puppies as well as the breeders of the hounds, for unless young hounds have their liberty, these points are not properly developed. In addition to this we are pleased to notice the liberty of action on the flags. The way they go skimming about the kennel yards indicates they will be able to slip along whenever they get a fox in front of them, and make somebody look sharp if they mean keeping with them. I have a great deal to be thankful for, for though I have been rather severely crushed, I feel I am so far recovered to hope to see foxhounds in the field in a few weeks' time." Alas, the following December poor Tom Firr went over to the great majority, passing peacefully away at the age of sixty-one, some three years after his retirement from the post of huntsman to the Quorn.

Captain Pennell Elmhirst's note on the Belvoir kennel in the pages of the Field, July I9o3, says: "That the Belvoir maintain its supremacy is due to no fashionable prejudice, but to the fact that it keeps moving onwards, continually solidifying its type and rising upwards towards its highest examples. To quote the words that have long constituted the principle of management, 'Belvoir never goes very far from itself,' but after rare occasional trials outside, invariably returns quickly to the parent stock. Of course, the Belvoir hounds are extraordinarily inbred, but, so far from this leading to deterioration, it has allowed them to acquire a pattern of strength and symmetry wholly unrivalled. To-day they stand out more beautiful, 
more powerful, and more uniform than ever. Weathergauge (' 76 ) is the keynote of the present kennel, and he was the outcome of generations of Belvoir blood. This goes to prove that you can afford to inbreed foxhounds much more closely than many believe. I notice, too, that the power of limb for which Weathergauge was remarkable, and which he transmitted to his offspring, has by now been intensified. Another characteristic of his which was visible in many of his earlier descendants, viz., shortness of neck, by no means belongs to the present generation. It has, indeed, been practically eradicated by careful selection in breeding."

Old Dexter, a marvel of constitution in his eighth season, was represented by a number of beautiful bitches in the entry of I903, and Vagabond, who was the next most-sought-after sire of the day, put the stamp of Belvoir on the legs, feet, necks, and shoulders of all his "get." The top dog of this year's entry was Day Star, by Dexter from Destiny ('98), by Belvoir General ('93), son of Grafton Deputy ('87) and Belvoir Gladness ('88), the dam of Destiny being Belvoir Shamrock ('87), and Diligence ('89). A very level hound, standing $23 \frac{1}{2}$ inches, with wonderful bone and round feet, the critics placed him very high amongst the champions seen in the kennel during the past twenty seasons. Nearly a whole-coloured black hound with rich tan head, he was walked by Mr. Charles Hickson, of Bottesford, and his career at the stud was awaited with much interest by hound-breeders. Unfortunately, Day-Star was killed out hunting by the kick of a horse in his second season, and again the kennel suffered disappointment at a moment when they were looking out for a worthy successor to Dexter or Dasher.

A very nice dog in this entry, placed second, 
was Helper, nearer the 23-inch standard of height, by Handel from Ruby, walked by Mr. Dean, of Dowsby. Helper carries his bone well down, and has the roundest of cat-like feet.

Like the great entry of 1899 , opinion was considerably divided between the merits of some two couple of dog-hounds put forward in I906, clearly proving that it was an exceptionally strong one,

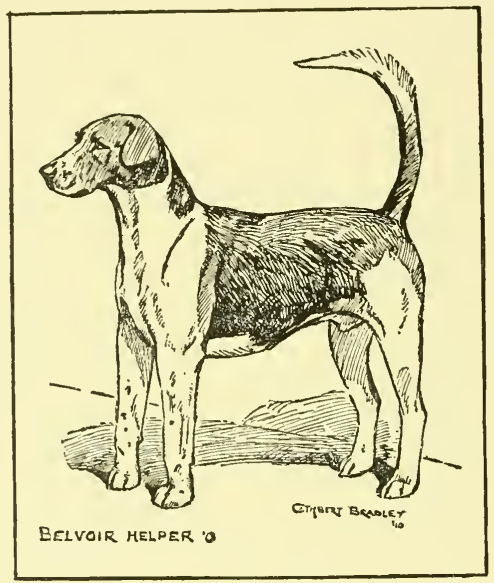

likely to make its influence felt on subsequent entries. The Rev. Cecil Legard had for his colleague on this occasion Tom Bishopp, huntsman to the Quorn, and their task to divide the entry was by no means an easy one. Again Captain Pennell Flmhirst, in his annual article to the Field, after a visit to Belvoir before the judging had taken place, gives a valuable summary of the entry. "This year the visitor will not fail to find the model-Weaverwhile he cannot help being impressed with the fact that the whole entry of the young dog-hounds is extraordinarily good. Perhaps the most treasured 
NOTES FROM THE BELVOIR KENNEL 265 strain in kennel, apart in the direct male line from Weathergauge, as represented more recently by the great Dexter, is that of Vagabond of I899, by Vanquisher, by Hermit, by Grove Hark-away. Vagabond has done great service in his own kennel, and see what he has done for the Atherstone and others! Wherever used, he has given quality and fashion,

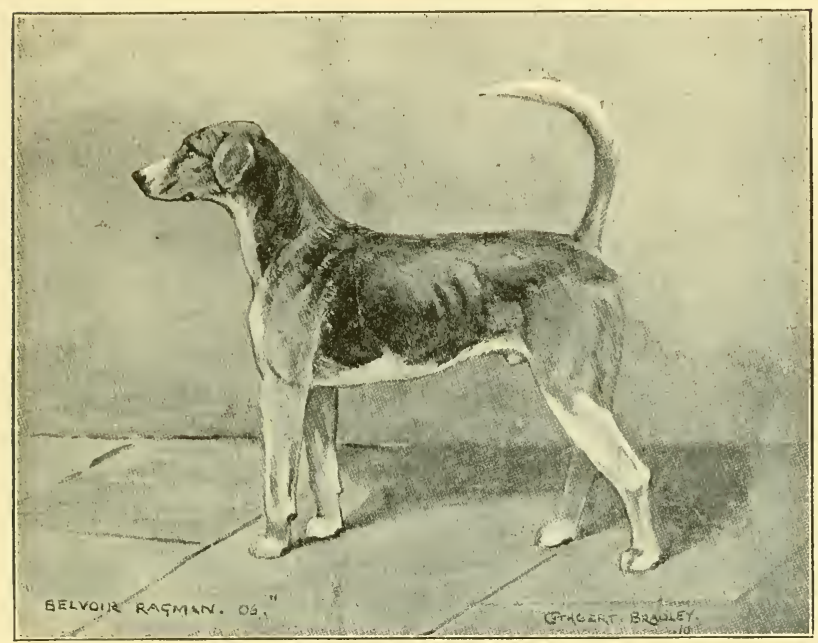

with admirable necks and shoulders, fine tongue, and marked capacity in the field. Vagabond took second prize in his year, but was early marked for distinction at the stud, and has proved one of the greatest successes of our time."

Placed top of the Igo6 entry was Ragman, son of Royal ('03), by Holderness Rustic ('97), by Belvoir Rustic ('94), by Watchman ('92). The dam of Ragman is Heresy (Igoo), by Dexter ('95) from Honesty ('92), by Hermit ('90) from Sunshine ('86), and he was walked by Mr. R. C. Cooper, of Waltham. An 
upstanding hound on the best of feet and legs, with neck, shoulders, and back to please the most critical eye, he looks built on the lines of a grass-country hunter. Standing all 24 inches, his measurement round the heart is $32 \frac{1}{2}$ inches, exceeding that of Gambler ('84), who was 3 I inches. With typical Belvoir colouring and possessing great length from hip to hock, he looks the sort to race up to a fox, and has the character for being a very determined hound in chase. Ragman is much sought after as a sire, his young stock at Quorn, Cottesmore, and in his own kennel possessing great muscular development and bone, besides the best of hunting qualities. Mr. R. C. Cooper, who walked Ragman, also his sire Royal, and afterwards a son Rioter, relates how all three possessed the same hereditary habit of lifting the latch of the kitchen-door. Afterwards when he walked the puppy of another family and showed him the latch-door, he had no idea of using it. We also have experiences of a Ragman puppy named Grammar ('o9), walked for the Belvoir ; he had a marvellous knack of ingratiating himself with everybody, was a good forager, a great admirer of the fishmonger, a capital companion to take out hedgerow shooting, spent much of his time sleeping on the sofa at the public-house, and was beloved by all the small village school-children.

A yellow-tan dog was placed second named Rufus, by Ranter ('03), by Vagabond ('99), his dam being Winsome. A low-set muscular hound, in style and outline he much reminded us of Crambler ('84), and was walked by Mr. J. Lewis, of the Angel Hotel, Grantham. The third dog of the entry, Weaver, came in for general admiration, and he was a long, low hound, just the outline we look to find in a weight-carrying hunter of quality. Of him Captain 
Pennell Elmhirst said, "Head, neck, and shoulders are material for a painter, while back and quarters are built for work and stamina. In my humble opinion, Weaver is one of the six model foxhounds of my experience." Measurements are very deceptive, and Weaver's exquisite quality was such that we did not realise that he was the deepest-ribbed dog ever seen on the flags at Belvoir, taping $34 \frac{1}{2}$ inches, measured by Mr. Cecil Legard. Gambler ('84) was regarded as a model of make and shape, and his heart measurement was $3 \mathrm{I}$ inches. Round the arm we measured Weaver $8 \frac{1}{2}$ inches; Gambler was $8 \frac{1}{4}$. Below the knee both Gambler and Weaver's measurements were $5 \frac{3}{4}$ inches of solid bone. A longer hound than Gambler, and shorter in his couplings than his maternal grandsire Dexter, he possessed that beautiful weighty appearance so characteristic of all the Gambler sort. By no means short on the leg, in spite of the deep ribs which at once caught the eye, he was a beautifully balanced dog on the best of hocks-a point Mr. Austin Mackenzie noted and admired. His colour was glorious--the richest of Belvoir tan, blue-black and dazzling white, and his white collar marking exactly right to show the line of the shoulder. Weaver had a beautifully intelligent head, with that wise, wistful expression so characteristic of the Belvoir blood; and Ben Capell said of him, "He is the best workman and kindest dog-hound ever hunted." In chase he was not difficult to find, even in a pack where so strong a family likeness prevails; at the stud he was in great demand, his young hounds at home being at the top of their entry.

Weaver's pedigree combines the blood of many notable sorts, being by Warlaby ('04), who was the top of his entry, a son of Wonder, who was by 
Grafton Woodman. The dam of Warlaby was Violet, by Vagabond from Heartless, a Dexter bitch. Then Garnish, the dam of Weaver, was by Dexter from Gambol, so he was a triumph of breeding as well as a model of make and shape, and was walked by Mr. Furmidge, of Harby. Another valuable sire in this entry was Warlock, considered to be the best representative son of Stormer ('99), but a bigger hound than his sire, possessing his exquisite neck, shoulders, and feet, which were a pattern to go by.

Whitaker, in demand as a stud hound, was litter brother to Weaver, and a rich-coloured hound, with good rib measurement; the full entry of I906 supplying seven couple of stallion hounds, which included Hampton, by Dexter, and Valorous, by Vagabond.

Owing to the last and serious illness of the late Duke of Rutland, the toast list and speeches were cut down on this occasion at the luncheon to the narrowest possible limits, but Sir Gilbert Greenall said, "He believed the judges, and all who had visited the kennels during the summer, agreed this was the finest entry they had ever seen put on at any place in England-never mind Belvoir!" When responding for the toast of the judges, Mr. Cecil Legard said, "Speaking for himself, he could say that a finer and nobler lot of young hounds he had never seen together, in an experience of nearly forty years. It was a matter of great regret that the venerable Duke was unable to be present, for it would have been a source of great satisfaction to him to see the Belvoir maintaining its own magnificent size, quality, and power, points looked to by all masters of hounds in England for keeping up the excellence and size of their own kennels. His late old friend Lord Willoughby de Broke liked a middle-sized hound; but he was 


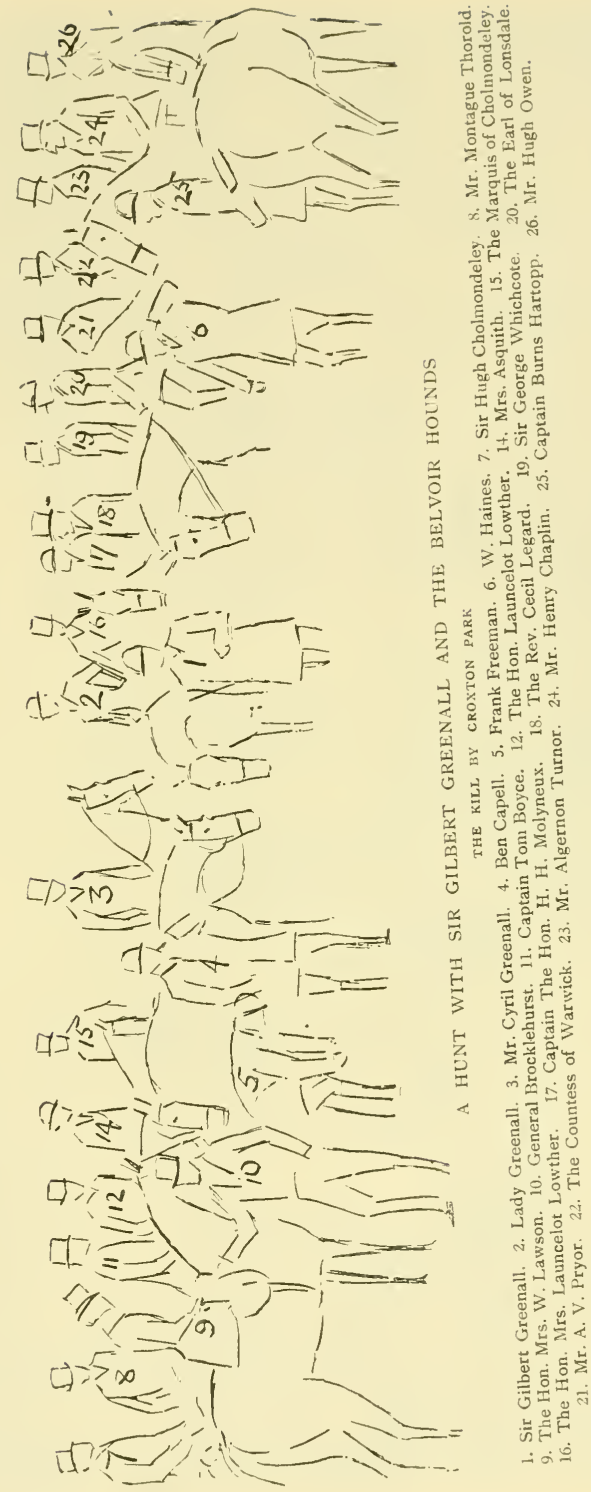





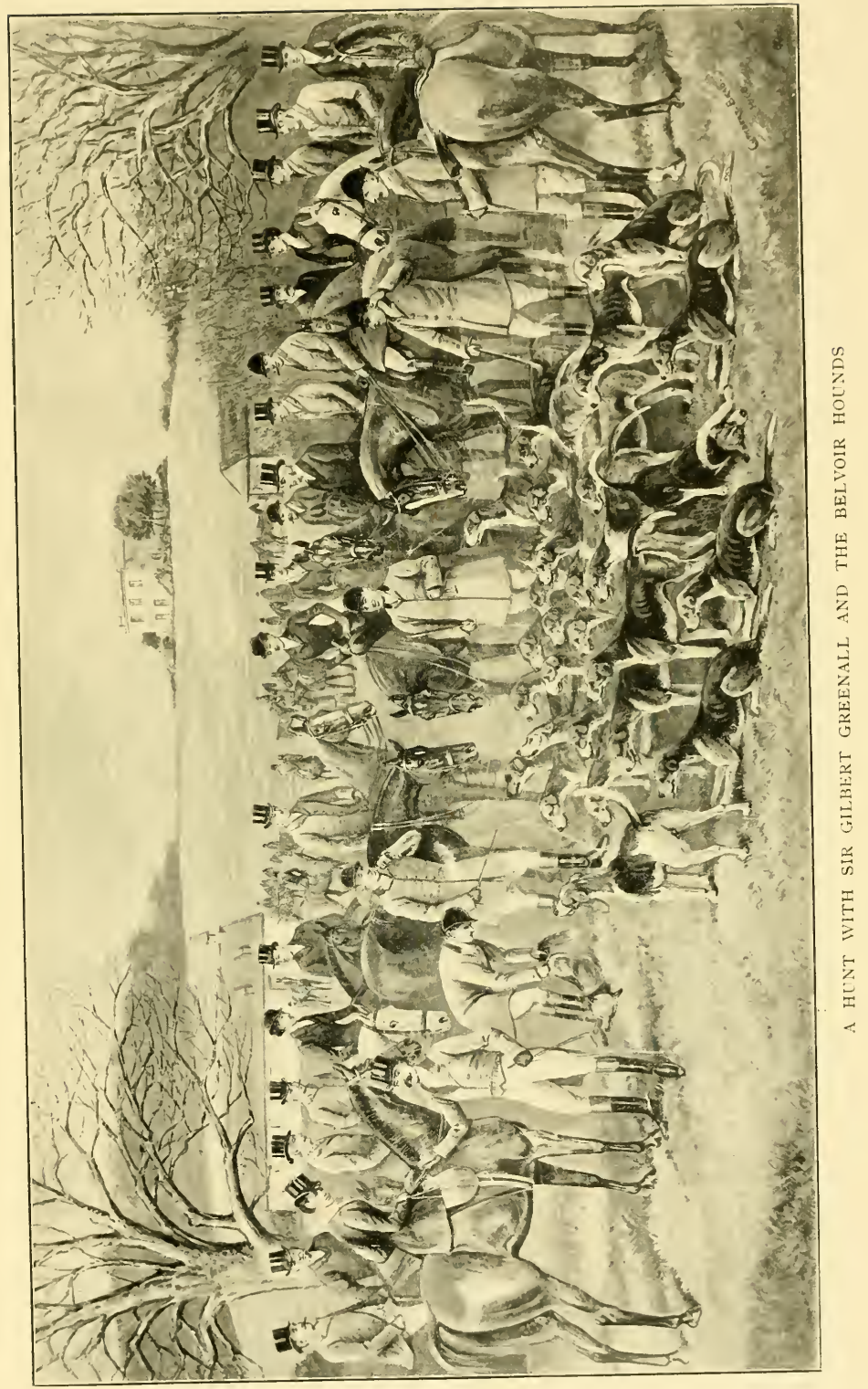



always anxious that the Belvoir size should be maintained, so that he might have the benefit of using them !"

Like his predecessors, the present and eighth Duke of Rutland talies the keenest interest in the hounds, which are a cherished family possession, and is frequently at the kennels, where Ben Capell spends many an hour showing on the flags.

A lawn meet at Belvoir Castle makes a splendid finish to the season's sport, and on Saturday, April 3, I9o9, a representative gathering from Melton and Grantham assembled for the last time, enjoying a hunt of great excellence. Ben Capell, with the two whippers-in, Jack Hewitt and Herbert Norman, had the doghounds in the field, all the celebrities of the pack about whom we have been talking, looking like burnished silver in the bright sunshine. The Duke and Duchess of Rutland were on foot to see the hounds, and their three daughters, the Ladies Marjorie, Violet, and Diana Manners,

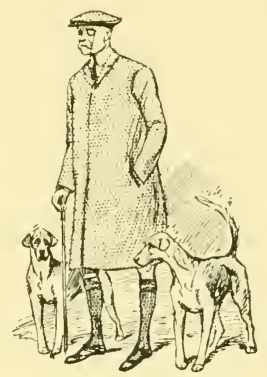

The present and 8 th Duke of Rutland. were amongst the keenest division who ride in the vale of Belvoir. Sir Gilbert Greenall was in command, with Lady Greenall, and their two promising boys, Master Gilbert and Edward Greenall, on their ponies, the elder of the two with his miniature hunting horn, the younger with the couples to his saddle. The field included Lord Robert Manners, Lady Robert Manners walking, the Marquis of Cholmondeley, Lord George Cholmondeley, Elizabeth, Countess of Wilton, and Mr. A. V. Pryor, the Earl and Countess of Scarborough, General Sir Mildmay Willson, Miss Willson, Mr. and Mrs. E. Wr. Griffith, Master Griffith, the three Miss Bibbys, 
General Brocklehurst, Colonel and Mrs. E. H. Baldock, Colonel Balfour, Mrs. E. Lubbock, Miss Nancy Lubbock, Major J. H. W. Rennie, Mr. Ernest Chaplin, Major A. R. Markham, Mr. C. de Paravicini, Mr. F. H. Schwind, Captain R. and Mrs. Ellison, the Hon. Mrs. Lionel Walrond, Sir Charles Welby, Miss Welby, Major and Mrs. R. B. Muir, Miss Muir, Mrs. Jefferson, Captain and Mrs. R. B. Sheriffe, the Hon. H. R. Scott, Mr. A. Hutchinson, Mr. R. E. Strawbridge, Mr. T. Hare, Mr. G. Drummond, the Hon. W. R. Wyndham, Captain and Mrs. A. Smith, Mr. F. Hardy, Major R. A. Markham, Mrs. C. Cradock, Mr. G. Coats, Mr. T. Coats, Mr. H. R. Langrishe, Captain Vickerman, Mr. P. H. Coxe, Mr. W. H. Wilkinson, Mr. R. C. Cooper, the Rev. F. Knox, the Rev. J. P. Seabrooke.

A find was proclaimed in the Saltbecks, a covert in the valley at the back of the Peacock Inn, and driving their fox out at a great pace through Muston Crorse, they passed the Debdales on the left, going on below the Privet Covert at Allington. Then turning bang up wind they raced for the Foston Beck, in the banks of which are some well-known earths. Warbler ('03), the tan dog by Wonder ('98) from Vanity ('OI), a descendant of another famous tan dog Drayman, was as usual one of the leading couple, and the pack travelled fast-a six-mile point in 37 minutes without a check. Near the finish, and only 300 yards from the Foston Beck, the fine old dog-fox was viewed by many of the hunt just struggling across a plough field, "beat to all the world." Then Weaver got the lead, and, racing up to his fox, caught him by the brush, never letting go until the others dashed up and effected a kill, himself getting marked through the ear.

The honours of this fine hunt were with Mr. 
NOTES FRON THE BELVOIR KENNEL $27 I$

T. Hare, riding his well-known grey horse; Captain "Dick" Ellison also being close up, and the ground being rather holding across a line of alternate grass and plough, many of the horses were ridden to a standstill. One of the Lady Manners took a harmless fall at an awkward fence; but General Sir

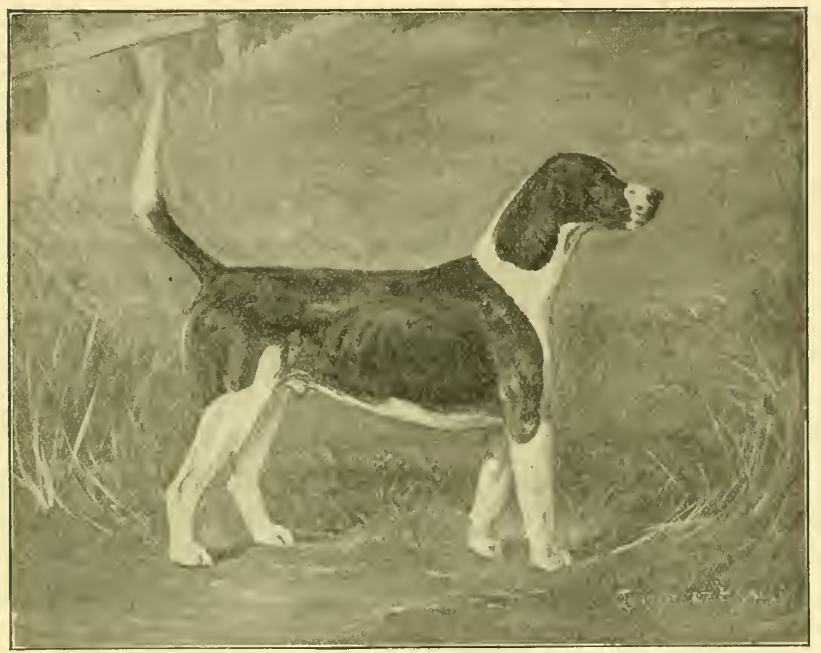

Belvoir Weaver ('o6), died from the result of a hunting accident, I9Io.

Mildmay Willson received a shaking fall when his horse came down, rolling on him.

By a lucky chance Lady Greenall's two small boys turned up at the finish, in charge of Harry Latham, the stud groom, and to Master Gilbert was presented the brush of the last fox of the season I9o8-9, the mask being attached to the saddle of his brother, Master Edward, riding the long-tailed white pony-quite an eventful day's sport, which these youngsters did not forget to enter in their diary when they returned home! 
As was the case in I906, when Ragman and Weaver met in rivalry on the flags at the puppy show, so when the entry of Igog was judged by the Rev. Cecil Legard and George Whitemore, huntsman to the Atherstone, their respective progeny fought out the issue for premier honours, proving that like begets like. After a rigorous examination of points, the prize was awarded to Wizard, the son of Weaver ('06), who had the distinction of sireing the first-prize dog-hound in the previous Belvoir

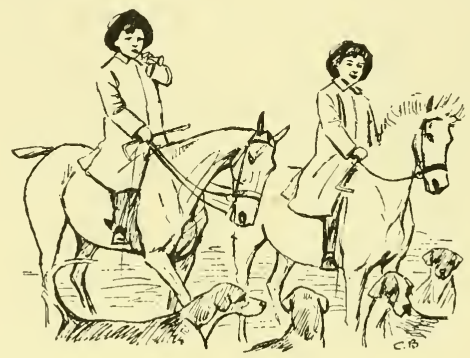

In the Field.

entry, namely, Vulcan ('o8), walked by Mr. Cecil Rudkin, of Sapperton. The winner of the Igog entry, Wizard, from Spiteful ('o4) by Ringwood ('or), was walked by Mr. Godson, of Eastwell, and is a lowset, powerful dog, a model in outline, with distinguishing white ticks in his coat. The second prize was awarded to Rallywood, son of Ragman ('o6) from Ransom ('03), a daughter of Vagabond ('99), walked by Lord Hamilton, of Dalzell, and the Masters Gilbert and Edward Greenall. Rallywood is a fine, upstanding, young hound, whose lines are indicative of speed, and it will be interesting to see how he develops with time and work. In the judging ring helping Ben Capeli and the whippers-in were 
NOTES FROM THE BELVOIR KENNEL 273 two little cherubs in white kennel coats who won all hearts, the sons of the master and Lady Greenall.

In conclusion we will take a passage by a writer in Baily's Magazine of September I906, which gives the pith of what we have attempted to set forth as the salient points in the history of the

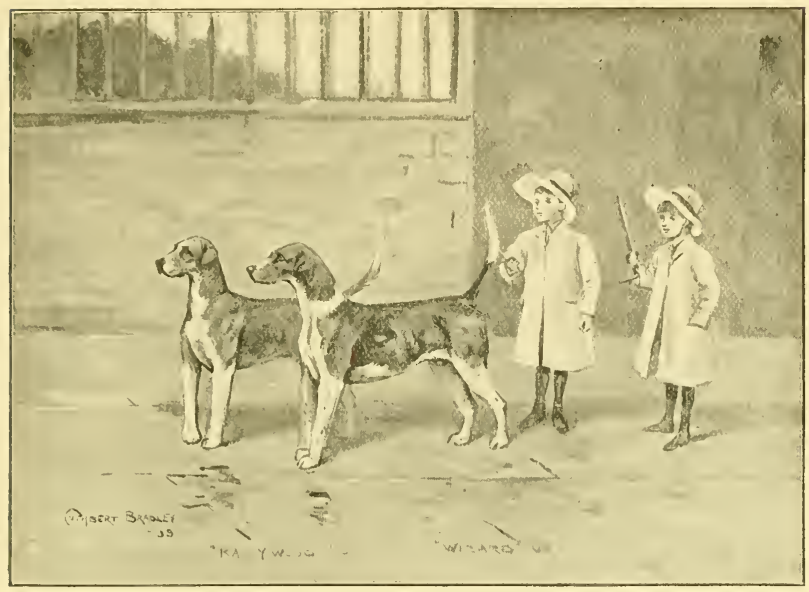

The Master Greenalls in kennel.

Belvoir kennel. "It was partly judgment and partly good fortune that gave to the hunt, in Goodall, Gillard, and Capell, huntsmen to whom the selection of foxhounds for breeding amounted to a positive genius. Goodall's Rallywood, by Brocklesby Rallywood, founded the present race of Belvoir; Gillard's Weathergauge and his sons built it up; Capell's Dexter, Dasher, Vagabond, Stormer, and Handel crowning the edifice." 


\section{NDEX}

A

Agricultural, Royal, Society Show and Sir Gilbert Greenall, 9 I

Alexandra Palace Fox Hound Show, 32

Amcotts, Major Fritz, 69

Ancaster, the Earl of, 65, 204, 253

Annaly, M.F.H., Lord, 158

Armour, Mr. Harry, 107, 217

Asquith, Mrs. H. H., 36, 227 .

Atherstone "Challenger" and other hounds, I 3, I I 5

\section{B}

Badminton, Ilouse and kennels, 73

Badminton hunt with the Duke of Beaufort's hounds, 77

Badsworth "Finisher," I 86

Badsworth, hunting run, 186, I8 7

Baird, M.F.H., Mr. William, 60, 199

Baker, George, huntsman to the Cambridgeshire, I 7 I

Barford, Mr. William, 4

Barnard, Will, huntsman to Mr. G. Fitzwilliam, I I, 2 IO

Bartlett, F., huntsman to Earl Fitzwilliam, 23

Bathurst, M.F.H., Earl, 25

Bathurst, the Hon. Lionel J., 7, I66

Beagles Pocket, Lord Hopetoun's, 218

Beau Brummel, 206

Beaufort Hounds, “ Justice," 73: "Victor," "Raglan," “Ringwood," " Woldsman," 79; " Rapture," 74; “Vaulter," 77

Beaufort, MI.F.H., the Duke of, vi., I I, I 2, +I , 72, 92, 254

Bellamy, Mr. Garner, I 43

Belper, Lord, 35

Belvoir Castle and kennels, 269, 295

Belvoir hunting runs, $44,126,225,269$

Belvoir Stud Hounds, "Weathergauge," 248 ; “Fallible," 248 ; " Gambler," 250 ; "Dexter," 25 I ; “Dasher," 259; " Vagabond," 257 ; “ Daystar," 268; "Helper," 264; "Weaver," 267, 271 ; "Ragman," 265; " Wizard," 273; "Rallywood," 273

Bentinck, M.F.H., Lord Charles, 97, 109

Bentinck, M.F.H., Lord Henry, vi., 98

Bentley, Mr. H. Cumberland, 4I, 43

Berlin Horse Show, 84

Birdsall, kennels and stables, I 88

Bishopp, Tom, huntsman to Lord Middleton, 33, I 4I, 188, 264

Blankney, "Ambrose," 96, I02

Blankney hunting runs, 96

Bore, Jack, huntsman to the Warwickshire, If

Bosanquet, M.F.H., Mr. G. Smith, 166

Boxhall, E., whipper-in to Blankney Kennel, Iof

Boyce, Captain Tom, 36, I 37

Brarley, Mrs. Cuthbert, 55, 92, I O3, I 52, 239

Bradley, the Rev. E., "Cuthbert Bede," 66, I76

Brown, Captain J. Moray, "Dooker," vii 
Brown, Jack, huntsman to the Warwickshire, I7

Buccleuch, the Duke of, I 57

Burgess, Mr. G., I 83

Cambridgeshire hunting runs, hounds, 163 ; and "Dasher," I73

Campbell, Sir John Hume, 25, 116

Capell, Ben, huntsman to the Belvoir, 33, 97, I 28, 226, 24I, 256, 257, 273

Cardigan and Lancastre, the Countess of, 4O, 4I

Caswell, Mr. Tom, 49

Carter, George, huntsman to the Fitzwilliam, 8, 26, I 30

Champion Bridger, huntsman to Lord Zetland, 23

Chaplin, M.P. and M.F.H., the Right Hon. Henry, v, vi, 3, 36, 96, 99, 100

Chaplin, Mr. Cecil, 36, 37

Chaplin, Mrs. Cecil, 67, 69

Chaplin, Mr. Ernest, 69

Cheshire Hounds, South, "Tarnish," "Triumph," "Trilby," "Testy," I4; "Hecuba" and "Warcry," I6I

Christian, Dick, 203

Churchill, Lord Edward, 69

Coaching at Scarborough, 192

Coaten, Mr. A. W., IO9

Cockburn, Mr. N. C., M.F.H., 97, 100, 103

Collins, Mr. G. E., "Nimrod, Junior," I 54

Cooke, Sir William, M.F.H., 6

Cooper, James, huntsman V.W.H., 25

Corbet, Mr. Reginald, M.F.H., 14, 24, I60

Coston Covert, $225-243$

Cotswold, North, hunting runs and hounds, "Piteous," "Pilgrim," 25, I I 3 , I 17

Cottenham Steeplechases, I6.3

Cottesmore hunting runs, $58,158,196$

Cottrell, George, whipper-in to the Belvoir, 128

Coupland, Mr. John, M.F.H., I 28, I 36

Coventry, Mr. Arthur, 36

Craven, "Vagabond," 23

Crossley, Sir Saville, I 80

Crossman, M.F.H., Mr. Douglas, 167-173

Cunard, M.F.H., Sir Bache, 24, I 19, I 57

Curtis, M.F.H., Sir William, 26

Custance, Mr. Henry, 68, 90

\section{$\mathrm{D}$}

Dale, Rev. T. F., "Stoneclink," 7, 73, 78, 202

Dale, Will, huntsman to the Duke of Beaufort, I I, I 2, 74, I 53

Dickenson's, Messrs., Picture of Peterborough, 20

Dixon, Mr. Scarth, "Ebor," 7

Drake, M.F.H., Mr. T. T., and "Duster," 8

Driving, Lord Lonsdale's feat against time, 179

Drummond, Mr. G., 234

Dysart, the Earl of, and Buckminster Hall, 225

\section{E}

Earp, Alfred, whipper-in to the Belvoir, 38, 127, I 33

Edward VII., King, 4, 79, I66

Ellison, Captain "Dick," 27 I

Ellison, Mrs. R. J., 87

Elnuhirst, Captain Pennell, " Brooksby," 7, 244, 256, 262, 267

Escritt, Mr. H. M., "Tally-ho," I43 
Enniskillen, M.F.J., the Earl of, I 2

Evans, M.F.H., MIr. G. P., I I, I9, I 66

Exeter, M.F.H., the Marquis of, $215-222$

Exeter, the Marquis of Exeter's hounds and runs, 2 I 5-222

Fernie, MI.F.H., Mr. C. IV. B., 20

Fernie's, Mr. C. W. B., hound "Ferryman," 20, 32

Fielden, M.F.H., MIr. Joshua, 50

Filmer, MI.F.H., Sir Robert, 97, I I I

Finch, M.P., Mr. G. H., 199

Finch, Miss, 65

Firr, Tom, huntsman at Quorn, vi, 21, 22, 32, 37, I1 4, I19, 127, 128, I66, I97, $213,258,26$ I

Fitt, Mr. J. Neville, 99, 244

Fitzwilliam, M.F.H., Earl, 23, I65

Fitzwilliam, M.F.H., Mr. George, 5, I0, 2 Io

Fitzwillian hounds, "Sultan," 9; "Selim," 9 ; " Furrier," I I ; "Donovan," 1I ; "Harper," II

Folkingham, 45

Forester, Colonel H., 34, 40

Forester, MI.F.H., Captain Frank, 34, I4O, I 44, I 48

Forster, MI.F.H., Mr. F. Villiers, 222

Fox, MI.F.H., Mr. George Lane, 22

Freeman, Frank, huntsman to the Pytchley, 92, I 59

Fullerton, MI.F.H., Mr. J. S. H., 23, 26, 186, 257

Fullerton, Mrs. J. S. H., I 87

\section{G}

Gartree Hill, 29

Gifford, the Hon. Maurice, 23 I

Gillard, Frank, huntsman to the Duke of Rutland, vii, 2I, 38, 45, 88, I 27 , $233,246,273$

Gillson, Charles, huntsman to the Meynell, I 3

Gillson, George, huntsman to the Cottesmore, 58, 202

Gillson, Sam, huntsman to Lord Lonsdale, I6I

Gimcrack, 85

Goddard, I., whipper-in at Quorn, 143

Goodall, Will, vii, 9, 52, 247, 273

Gordon, Lindsay, 83

Graham, M.F.H., Sir Reginald, 6, 86, 98

Greenall, Lady, I 37, I 39, I 48, 227, 229, 26 I, 273

Greenall, Nasters Gilbert and Edward, 269, 272

Greenall, MI.F.H., Sir Gilbert, 5, 89, 90, 93, I 37, 226, 227, 229, 244, 247, 25 I, 273

Greetham Inn, 6I

Grey Bob of Belvoir, 87

Grey horses, 83

Griffith, Captain Wynne, 137, 261

Griffith, Mr. and Mrs. E. W., 9 I, I 42, I 43, I 45

Guest, MI.F.H., Mr. Merthyr, 86

Haines, Will, whipper-in at Belvoir, 9I

Hanbury, M.F.H., Mr. Evan, 196

Hardy, M.F.H., Mr. Gerald, I 3, I 7 , I I 7 , I 72

Hare, Mr. T., 270

Harford, Mr. IV. A., 2 I 4 


\section{INDEX}

Harriers, Lord Hopetoun's, 218

Harrington, M.F.H., the Earl of, I 33

Harrison, M.F.H., Mr. Fenwick, 24

Harry the Quorn runuer, 43

Hartop?, MI.F.H., Captain Burns, 34

Heathcote, M.F.H., Sir Gilbert, 45, 202

Heathcote, Mr. T. A. R., 45, 66, 69

Heathcote, the Misses, 46,70

Heathcote, the Rev. T., +6, 65

Hemery, AIr. Vincent, 48, 5I, 20I, 237

Hennesy's, Tom, crooked whip, I75, I 77

Hertfordshire "Sampler," 24

Hewitt, Jack, whipper-in to the Belvoir, 142, 227, 269

Holderness hounds, "Handel," "Dasher," "Sanguine," 23, I94

Holford, C.Y.O., Lieut.-Col. G., 80

Hopetoun's, MI.H., the Earl of, harriers and beagles, 2 I 7

Hornsby, Mr. and MIrs. James, 40, I 52

Hoyes, MIr. James, 258,260

Hunt, Mr. George and Mr. Henry, 69

Hurlingham Club, Iso

Hutchinson, Mr. Arthur, 64, 69

Isaac, Charles, huntsman to Mr. Fernie's, 20, II 2

Isaac, John, huntsman to the Pytchley, I 8, 20

Isaac, Tom, huntsman to the Blankney, I 22

Jull, George, whipper-in to the Cottesmore, 67

K

King, Captain, 235

Kingslev, Canon, 3

Kirby Gate, 28

Knott, Bob, of Belvoir, 48

Kyte, Walter, huntsman to the Quorn, 33

Lambton, Hon. Francis, 239

Langham, MI.F.H., Sir Herbert, I 3, I 12

Lawson, Col, the Hon. IV., 36

Leaf, George, Quorn huntsman, I 28, I4I, I44

Legard, the Rev. Cecil, 5, I2, I4, I8, 154, 165. 253. 257,264

Lenton Brook, 53, 65

Londeshorough, II.F.H., the Earl of, 97, IO4

Longstaffe, Major WV., 47, 69, 87

Lonsdale, M.F.H., the Earl of, vi, 24, 34, 37, 86, 98, I 52, I 55, I 79, 218

Lonsdale's, the Earl of, hound "Villager." 98 , IOI, I I

Lowe, Mr. G. S., 7

Lowther, the Hon. Lancelot, 35, 89, I 57, 165

Lowther, the Hon. Mrs. Lancelot, 40, 90, IOI, 238

Lubbock, Mr. Beaumont, 36

Lubbock, M.F.H., Mr. Edgar, 53, 69, 97, IO4, I4I 
Mackenzie, M.F.H., Mr. Austin, I 2, 74, I03, I 50, 157, 254, 267

Maher, Danny, 37

Maiden, Harry, whipper-in to the Belvoir, 48

Manners, Lord Edward, 46

Manners, the Ladies Marjorie, Violet, and Diana, 227, 269, 27 I

Manvers, M.F.H., Lord, 25

Marlborough, the Duke of, 36

McNeill, M.F.H., Mr. Charles, I7, 25, I I 4, I 62

Medcalf, W., huntsman to the Holderness. 23, 27, 194

Melton Mowbray, 23, 29

Melville, Major Whyte-. 37, 72

Meynell, M.F.H., Mr. Hugo, 8, I4

Meynell hounds, "Warrener," "Why Not," I 4, 24

Middleton, M.F.H., Lord, 22, I 86

Middleton's, Lord, hounds, I90 ; "Freshman," 201

Miles, Mr. Charles, "Dragon," 7

Milne, M.F.H., the Rev. E. A., 27

Milton hounds, "Furrier," "Fallible," I 30

Mirehouse, the Rev. J., 234

Muniz. Sir Albert, 78, 92, I 20

Musters, Mrs. Chaworth, 4

$\mathrm{N}$

Newcastle, the Duchess of, 36,162

Norman, Herbert, whipper-in at Belvoir, 227, 269

$\mathrm{O}$

Oakley hounds, "Leader," "Lasher," 9; "Dancer," I 3

Onslow, Major Hughes, 34, I 58

Osbaldeston, Squire, 29, 249

"Furrier," 249

Paget, Mr. J. Otho, "Q.," 7, 37, I48

Paravicini, Mr. Chandos, 147

Parrington, M.F.H., Mr. Tom, 4, 22, 26

Paynter, Captain George, I06

Peterborough Foxhound Show, 2-27, 258

Pole, M.F.H., Mr. R. Chandos, I 7, 2 I

Portsmouth, MI.F.H., Lord, 8, 73 , I I 5

Press, Jack, huntsman to the Cambridgeshire, I66

Preston, M.F.H., Mr. H. L., 5, 23

Priestman, M.F.H., Mr. Lewis, I 8 I -185

Pryor, Mr. A. V., 35,148

Pytchley hounds, "Forager," "Narquis," " Potentate," I 8, I9

Pytchley, Woodland, hunting run, I 50

Q

Quorn hounds, "Alfred," "Dreamer," 2 I, 32

Quorn hunting runs, 28 , I 28, I 37

"Rallywood," Brocklesby, 247, 273

Ranelagh Club, I 80 
Rawnsley, M.F.H., MIr. E. P., I5, 162

Reid, Dan, huntsman N. CotswolA, I2O, I 22

Reynardson, Mr. C. T. S. Birch, I75

Richardson, M.F.H., Mr. J. Maunsell, I I, 36, I64

Richardson, Mr. Charles, "Shotley," 7

Rigden, MIF.H., Mr. IV. E., I9, 23

Robarts, MIr. T. E., 65

Rouse, Admiral, 86

Rudkin, Mr. Cecil, 220, 272

Rudkin, Mr. James, 52

Rudkin, Mr. T. A., 54

Rufford hounds, "Falliard," 2 I

Rutland, the 6th Duke of, 65, 129, 2.46

Rutland, the 7 th Duke of, 247,260

Rutland, the 8th Duke of, 227,261, 268

Scarborough Coaching, I 8 I

Schwind, Mr. Frank H., I 47, 239

Schwind, Mrs. George, 55

Scott, Jack, whipper-in to the North Cotswold, I 2 I

Scratton, M.F.H., Mr. R. D., 8

Seabright, Tom, huntsman to the Fitzwilliam, 26

Seabrooke, the Rev. J. P., 90, I36, I45, I64

Seymour, M.F.H., Mr. C. D., I65

Shaw, "Gentleman," huntsman at Belvoir, 45

Shepherd, George, huntsman to the Blankney, I03, 106

Shrewsbury, Lord, I 79

Smith, M.F.H., Mr. Assheton, 29

Smith, M.F.H., Mr. Dudley, 25

Soames, Mr. F. A., 52

Spencer, M.F.H., Earl, I 8

Staffordshire, South, hounds and hunt, 223

Steeds, Captain Holloway, 90. I45

Steeplechase, Belvoir hunt, 66

Stokes, Mr. J. H., 79, I 53

Stoodley, the Rev. T. A., 56

Sunday clothes, 76

Sutton, M.F.H., Sir Richard, vi

Swan, MI.F.H., Mr. R. Clayton, I I6, 233

Swan, MIrs. R. Clayton, 95

Sykes, Sir Tatton, 22, I 87

Tempest, M.F.H., Major Arthur, 97

Thatcher, Arthur, huntsman to the Cottesmore, I91, I96

Theobald, Colonel Cotton, 138

Thomson, M.F.H., Colonel J. Anstruther, 22, 4I, 75

Time of Grand National compared with hunting, 235

Timson, M.F.H., Captain H. T., 93

Tomlinson, Mr. J., 22 I

Trollope, Mr. Anthony, $3^{8}$

Vanderbilt, Mr. A., I 78

Victoria, Queen, 245

V.W.H. hound, "Stentor," 25

Vyner, Mr. R., Notitia Venatica, I53 
Warner, M.F.H., Captain, $2 \mathrm{I}$

Warwickshire hounds, "Harper," “Hermit," “Pedlar," “Traveller," "Wizard," I5, I6, I7

Watson, M.F.H., Mr. John, 18, 24

Velby, Mr. John, I 29, 233

Welby, Sir Charles, 260

Wells, Will, whipper-in to the Belvoir, 24,58

Weston, Will, whipper-in to the Quorn, I4I

Wharton, M.F.H., Mr. IV. H., 23

Whichcote, Sir George, 52, 21 8

Whichcote, Sir Thomas, 9, 39

Whistles for hunting, 41, 80, I 23

Whitemore, George, huntsman to the Atherstone, I 3, 272

Whitemore, Tom, huntsman to the Oakley, 9, I2

Wilkinson, Mr. W. H., I 47, 239

Willoughby de Broke, M.F.H., Lord, 7, 14, 16, 25, 130, 268

Willoughby de Eresby, M.P., Lord, 53, 204

Willoughby de Eresby, the Hon. Claud, 53

IVilloughby de Eresby, the Hon. Margaret, 65

Willson, General Sir Mildmay, 27 I

Vilson, Arthur, whipper-in to the Belvoir, I37

Wilson, M.F.H., Mr. Arthur, 23, 194

IVilton, the Countess of, 35

Winn, M.F.H., Sir Watkin William, 48

Wood, Mr. Crawford, "Hymee," 7

Woodwell Head, 24I

Worcester, the Marquis of, 75

Wright, M.F.H., Mr. Charles B., I2, 14, 16, 49, 86, 165

Wroughton, M.F.H., MIr. WT. M., I I, I 8, I6I, 254

\section{Y}

Yarborough, MI.F.H., Lord, and hounds, 12, 76, I 5 I, 154,247

Yates, M.F.H., Captain Parke, I 37

Zetland, M.F.H., the Marquis, 23 



